\title{
REDES ELETRÔNICAS E NECESSIDADES DE INFORMAÇÃO: abordagem do Sense-Making para estudo de comportamento de usuários do Instituto de Física da USP
}

Tese apresentada á Escola de Comunicações e Artes da Universidade de São Paulo, como requisito parcial para obtenção do titulo de Doutor em Ciências da Comunicação, sob orientação da Profa. Dra. Neusa Dias de Macedo. 
Tese apresentada á Escola de Comunicações e Artes da Universidade de São Paulo, como requisito parcial para obtenção do Título de Doutor em Ciências da Comunicação, por Sueli Mara Soares Pinto Ferreira.

FOLHA DE APROVAÇÃO

BANCA EXAMINADORA

Presidente: Yeurathis de hracedo

Titular

Titular

Titular

Titular

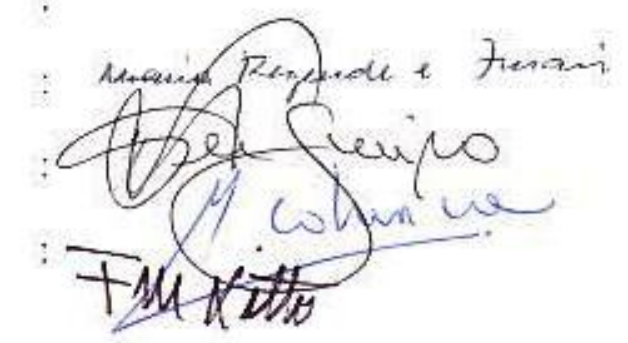


* Ás

minhas

estrelas * 


\section{AGRADECIMENTOS}

De modo particular e carinhoso agradeço a três orientadores. Ao Prof. Dr. Jose Augusto Vaz de Valente, que me acompanhou nos primeiros anos de estudo. Á Profa. Dra. Brenda Dervin pelas valiosas discussões mantidas "eletronicamente". E a Profa. Dra. Neusa Dias de Macedo, que muito mais do que mestra, amiga, companheira de trabalho acadêmico e orientadora, foi aquela "maezona" que todos precisam nesse difícil período. Sem ela, esse trabalho não teria chegado ao termino.

De modo geral, agradeço aqueles familiares, colegas de trabalho e amigos que indiretamente apoiaram esta trajetória e os que diretamente prestaram inestimável colaboração dentro de suas competências:

Ao Prof. Dr. Max Cohenca, Fabio Becherini, Maria de Fatima c os informantes, todos do Instituto de Física da USP, que proporcionaram meios para viabilizar esta pesquisa.

Ao Prof. Dr. Ubirajara Ferreira da UNESP e a Profa. Maria Beatriz F. Devloo da UNICAMP, pelo auxílio nas atividades de categorização e validação das análises de conteúdo desenvolvidas.

Ao professores Dr. Michael Nilan, Dra. Ruth Small, Dra. Martha Dosa, todos da Syracuse University c Dr. Robert W. Clousc, da Vanderbilt University, pelo interesse com que me acolheram durante meus estágios nas respectivas universidades.

Á Fernanda Guimarães, pelo trabalho de revisão gramatical e a Carmem Lucia Lopez, pelo auxílio na digitação das tabelas.

As minhas filhas, Maíra e Taína, pela energia e paz que transmitem, levando-me a recomeçar sempre.

Ao meu marido, pelo apoio, incentivo e assistência até os últimos minutos.

Á tia "Didi" pela longa hospedagem.

Ao CNPq, pelas bolsas de estudos concedidas no país e no exterior. 
FERREIRA, Sueli Mara S.P. Redes eletrônicas e necessidades de informação: abordagem do Sense-Making para estudo de comportamento de usuários do Instituto de Física da USP. São Paulo, Tese (Doutoramento) - Escola de Comunica9oes e Artes, Universidade de São Paulo, 1995.

\section{RESUMO}

Redes eletrônicas e necessidades informacionais, integradas para evidenciar comportamento de busca e uso da informação e compreender o papel dessa tecnologia no ambiente universitário, são os objetivos desta tese.

Dividida em três partes, enfoca primeiro o plano metodológico. A seguir, dois estudos de revisão fundamentam o trabalho: (1) rastreando a evolução de redes eletrônicas internacional e nacionalmente para sistematizar a matéria; (2) evidenciando pontos tradicionais de estudos de necessidades de informação para alcançar aqueles centrados no usuário. Na terceira parte apresenta pesquisa peculiar, em ambiente da USP cujo Instituto de Física constitui o universo de observação.

Por meio do correio eletrônico é perscrutada a conduta de busca e uso da informação de 87 usuários da rede local do IFUSP, no período outubro / novembro de

1994. A abordagem metodológica utilizada é adaptada do Sense-Making de Brenda Dervin, uma abordagem alternativa ou da percepção, que tem o usuário como objeto de pesquisa.

Submetidos a três tipos de análise, os resultados obtidos assim se configuram: (a) utilização das redes: tempo de experiência, freqüência, propósitos, barreiras e dificuldades, treinamentos; (b) busca e uso de informação: contexto de uso, natureza e foco das necessidades de informação, estratégias empregadas para solucionar problemas, esforço dependido para localizar respostas as necessidades, expectativa de uso da informação, recursos informacionais utilizados, completeza e satisfação com as respostas obtidas e fontes efetivas de auxílio e (c) necessidades de informação não solucionadas: contexto de uso, natureza e foco das necessidades, expectativa de uso e estratégias para solução.

Ponto significativo da pesquisa foi à categorização de usuários em 4 grupos, conforme as etapas gradativas do seu desempenho no uso das redes: fase 1 descobrindo a existência das redes eletrônicas e seus benefícios; fase 2 - já utilizando as três funções básicas da rede (correio eletrônico, ftp e telnet), porém de modo restrito, apenas usufruindo mais agilmente os recursos computacionais locais; fase 3 - buscas de solução a questões imediatistas, pontuais e de caráter variado; fase 4 - uso denotando experiência, segurança nas várias funções das RE. Dessa categorização e pelas 
solução a questões imediatistas, pontuais e de caráter variado; fase 4 - uso denotando experiência, segurança nas várias funções das RE. "Dessa categorização e pelas freqüências observadas em cada fase, infere-se que as redes eletrônicas têm sido utilizadas mais como um instrumento de comunicação do que real fonte de informação.

Similaridades nos procedimentos de busca e uso da informação entre os grupos estudados contribuíram também para delinear o perfil de necessidades informacionais de comunidade acadêmica que utiliza redes eletrônicas.

Para otimizar o uso das RE, sugere-se o desenvolvimento de estudos específicos das necessidades dos usuários; serviços pertinentes a essas necessidades; programas de capacitação de profissionais intermediários entre serviços e usuários finais, de formação em serviços e treinamento de usuários.

Palavras-chave: Redes eletrônicas / Necessidades de Informação / Sense-Making Approach I Internet / BITNET. 
FERREIRA, Sueli Mara S.P. Electronic Networking and Information needs: the SenseMaking Approach to study information seeking behavior with users at Physics Institute at University of São Paulo. São Paulo, SP, Brazil: School of Communication and Arts / USP, 1995. (Ph.D. Dissertation)

\begin{abstract}
Electronic Networks and Information Needs are integrated in order to search information seeking behavior of the academic community and to understand the impact of this technology in the university activities. Those are the issues of this dissertation, which is presented in 3 parts.

First - the methodology. Second - review studies which contain the fundamentation of this work: (1) electronic networking evolution; and (b) traditional versus oriented approach to study the user needs. Third - information seeking behavior research of the electronic networking users at the Physics Institute of the University of São Paulo based in Brenda Dervin's Sense-Making Approach.

The electronic mail was used in order to get information from 87 users of IFUSP local network. The results were submitted to three types of analysis: (a) use of the electronic network: amount of experience, frequency and purpose of use, barriers and difficulties, amount of training and context of use; (b) search and use of information: nature and entity focus, strategy used, amount of effort, resource used, user expectation and actual uses, completeness of the answers obtained, usefulness of the answers, sources that effectível y helped to find the information; (c) unsolved information needs: failure, analysis of user's problems when their information needs remained unsolved was performed.
\end{abstract}

Users were classified in 4 groups, according their performance in networking: (1) those in discovering electronic networks benefits stage; (2) those using basic functions (email, ftp and telnet) but only locally; (3) those seeking for solutions or immediate issues; (4) expert users. From this characterization and due to the user's frequencies in each of these stages, an inference of IFUSP net is done: most users are just at the communication stage, not using networks as an information source.

Similarities in the information seeking behavior of those IFUSPnet users contribute to outline the community user needs characterization. As suggestions in order to improve the electronic networks use, it should develop specific studies of user needs, offer users competence program and professional in service training.

Key-words: Electronic Networking / Internet / BITNET / Information needs and use / SenseMaking Approach / Information seeking behavior 


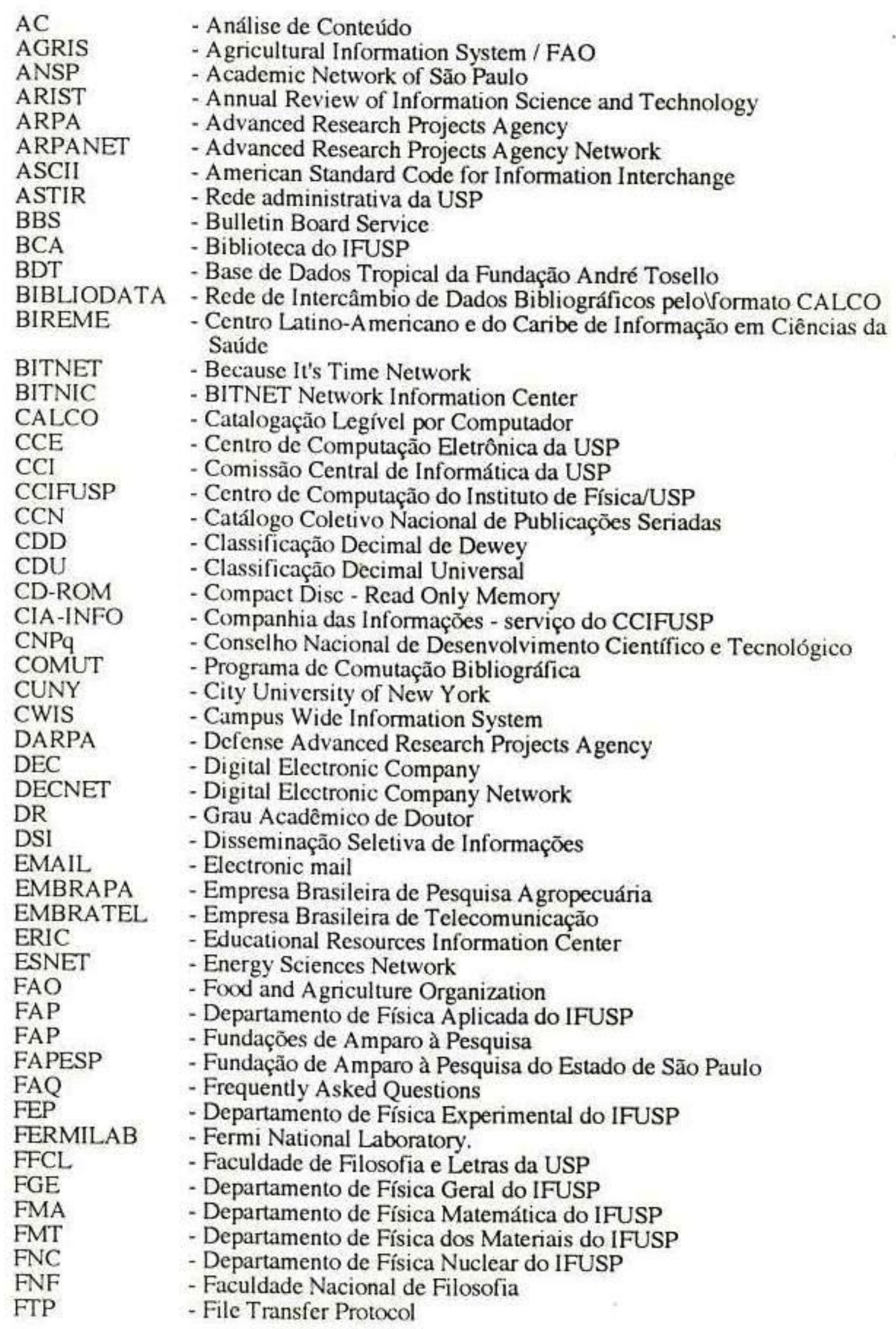




\begin{tabular}{|c|c|}
\hline GAN & - Global Area Network \\
\hline GATI & - Grupo de Assessoramento Técnico em Informática da USP \\
\hline GR & - Grau Acadêmico de Graduado em Curso Superior \\
\hline HEPNET & - High Energy Physics Network \\
\hline IAG & - Instituto Astronômico Geofísico da USP \\
\hline IBICT & - Instituto Brasileiro de Informação em Ciência e Tecnologia \\
\hline IFUSP & - Instituto de Física da USP \\
\hline INFOTERRA & $\begin{array}{l}\text { - International Referral System for Sources of Enviromental } \\
\text { Information }\end{array}$ \\
\hline INIS & - International Nuclear Information System \\
\hline INTERNET & - Interconnected Networks \\
\hline ISA & - Information Science Abstract \\
\hline ISDS & - International Serials Data System \\
\hline ISO/OSI & - International Standard Organization/ Open Systems Interconnection \\
\hline LAN & - Local-Area Network \\
\hline LD & - Grau Acadêmico de Livre Docente \\
\hline LNCC & - Laboratório Nacional de Computaçāo Científica \\
\hline MCT & - Ministério da Ciência e Tecnologia \\
\hline ME & - Grau Acadêmico de Mestrado \\
\hline NCP & - Network Control Protocol \\
\hline NREN & - National Rescarch and Education Nctwork \\
\hline NSF & - National Science Foundation \\
\hline NSFNET & - National Science Foundation Network \\
\hline OCLC & - Online Computer Library Center \\
\hline ONG & - Organizaçōes não governamentais \\
\hline ONU & - Organização das Naçōes Unidas \\
\hline OPAC & - Online Public Access Catalog \\
\hline PD & - Pós-Doutorado \\
\hline PRODASEN & - Processamento de Dados do Senado Federal \\
\hline PUC & - Pontifícia Universidade Católica \\
\hline RE & - Redes Eletrônicas \\
\hline REDUSP & - Primeira rede acadêmica da USP \\
\hline RENPAC & $\begin{array}{l}\text { - Rede Nacional de Comunicação de Dados por } \\
\text { Comutação de Pacotes }\end{array}$ \\
\hline RITLA & - Red de Información Tecnológica Lationamericana \\
\hline RNP & - Rede Nacional de Pesquisa \\
\hline RSCS & - Remote Spooling Communication Subsystem \\
\hline SIBI & - Sistemas de Bibliotecas da USP \\
\hline SLIP & - Serial Line Internet Protocol \\
\hline SMA & - Sense Making Approach \\
\hline SPAN & - Space Analysis Network \\
\hline TCP/IP & - Transmission Control Protocol /Internet Protocol \\
\hline UCLA & - University of California at Los Angeles \\
\hline UFRGS & - Universidade Federal do Rio Grande do Sul \\
\hline UFRJ & - Universidade Federal do Rio de Janeiro \\
\hline UNESP & - Universidade Estadual Paulista \\
\hline UNICAMP & - Universidade de Campinas \\
\hline USP & - Universidade de São Paulo \\
\hline USPnet & - Rede Eletrônica da Universidade de São Paulo \\
\hline VERONICA & $\begin{array}{l}\text { - Very Easy Rodent-Oriented Net-Wide Index to } \\
\text { Computerized Archives. }\end{array}$ \\
\hline VM & - Virtual Machine \\
\hline & - Wide Area Information Servers \\
\hline & - Wide Area Network \\
\hline & Vorld Wide Web \\
\hline
\end{tabular}




\section{LISTA DE TABELAS}

\section{CAP.4}

4.2.6.1 Distribuição e retorno de instrumentos de coleta de dados $\times$ Classes de usuários da rede IFUSP

4.2.6.2 Distribuição do número de instrumentos de pesquisa respondido por dpartamento $\mathrm{x}$ Classes de usuários da rede IFUSP

4.2.6.3 Dados demográficos dos informantes $x$ Classes de usuários da rede IFUSP

4.2.6.4 Distribuição dos informantes por grau acadêmico, ano de formaçāo do mais alto nível obtido e local de obtenção

\section{CAP.5}

5.1.1.1 Tempo de experiência com computadores $\mathrm{x}$ Classes de usuários da rede IFUSP

5.1.2.1 Experiência no uso de redes eletrônicas x Classes de usuários da rede IFUSP

5.1.3.1 Conhecimento e uso dos recursos disponíveis $x$ Classes de usuários da rede IFUSP

5.1.4.1 Participação $\mathrm{cm}$ listas de discussão $\mathrm{x}$ Classes de usuários da rede IFUSP

5.1.5.1 Propósitos no uso das redes eletrônicas $x$ Classes de usuários da rede IFUSP

5.1.6.1 Barreiras no uso das redes $x$ Classes de usuários da rede IFUSP

5.1.7.1 Dificuldades no accsso à informação $\mathrm{x}$ Classes de usuários da rede IFUSP

5.1.8,1 Treinamento para o uso de redes eletrônicas $\mathrm{x}$ Classes de usuários da rede IFUSP

5.2.1.1 Contexto de utilização das redes eletrônicas x Classes de usuários da rede IFUSP

5.2.2.1 Natureza da questāo do usuário $\mathrm{x}$ Classes de usuários da rede IFUSP

5.2.2.2 Naturcza da questão do usuário $\mathrm{x}$ Contexto de utilização das redes eletrônicas

5.2.3.1 Foco da questão do usuário $x$ Classes de usuários da rede IFUSP

5.2.3.2 Foco da questão do usuário x Contexto de utilização das redes eletrônicas

5.2.4.1 Expectativa de uso da informação $x$ Classes de usuários da rede IFUSP

5.2.5.1 Estratégias empreendidas $x$ Classes de usuários da rede IFUSP

5.2.6.1 Completeza da resposta obtida $x$ Classes de usuários da rede IFUSP

5.2.6.2 Avaliação da completeza da resposta obtida x Classes de usuários da rede IFUSP

5.2.7.1 Satisfaçāo com a resposta obtida x Classes de usuários da rede IFUSP

5.2.7.2 Avaliação da satisfação com a resposta obtida $x$ Classes de usuários da rede IFUSP

5.2.8.1 Esforço dispendido na localização da resposta $x$ Classes de usuários da rede IFUSP

5.2.9.1 Recursos informacionais x Classes de usuários da rede IFUSP

5.2.10.1 Fontes de informação $x$ Classes de usuários da rede IFUSP

5.3.1.1 Contexto de utilização das redes eletrônicas $x$ Classes de usuários da rede IFUSP (necessidades de informação não solucionadas)

5.3.2.1 Natureza da questão do usuário x Classes de usuários da rede IFUSP (necessidades de informação não solucionadas) 
5.3.3.1 Foco da questão do usuário $\mathrm{x}$ Classes de usuários da rede IFUSP (necessidades de informação não solucionadas)

5.3.4.1 Expectativa de uso da informação $x$ Classes de usuários da rede IFUSP (necessidades de informação não solucionadas)

5.3.5.1 Estratégias empreendidas $x$ Classes de usuários da rede IFUSP (necessidades de informação não solucionadas)

\section{APÊNDICE C}

Tabela - Uso dos recursos disponíveis nas redes eletrônicas x Classes de usuários da rede IFUSP 


\section{SUMÁRIO}

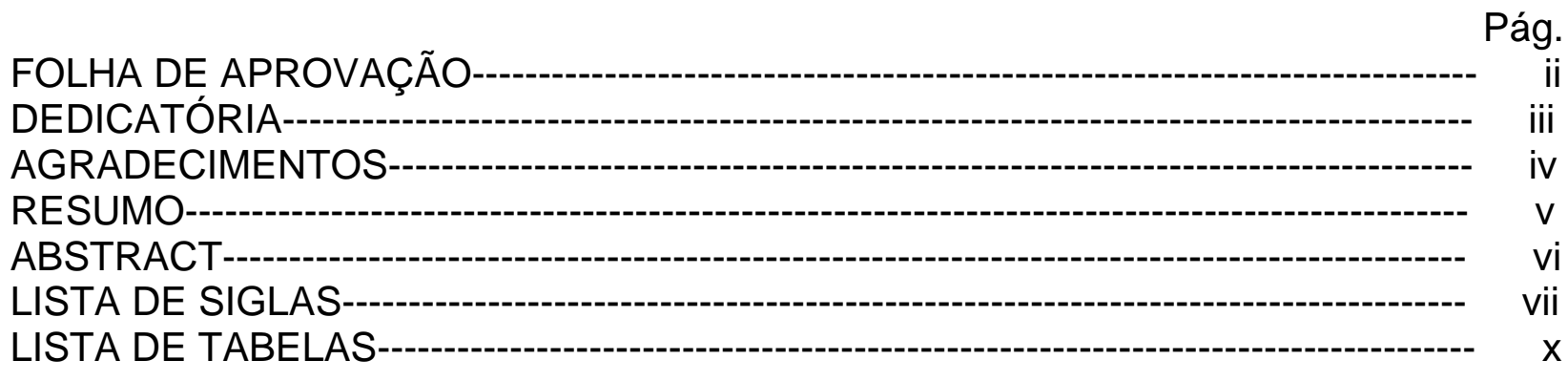

\section{PARTE I \\ Plano metodológico}

CAP.1 APRESENTAÇÃO DO ESTUDO E PESQUISA 2

1.1 Rede eletrônica e necessidade de informação-----on

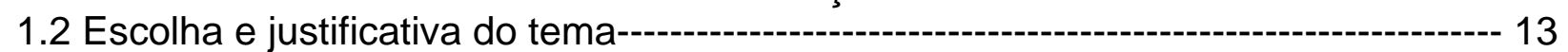

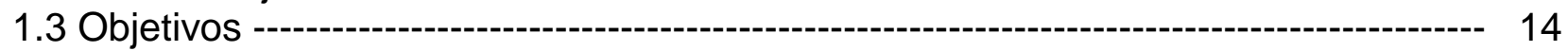

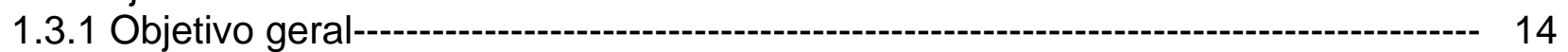

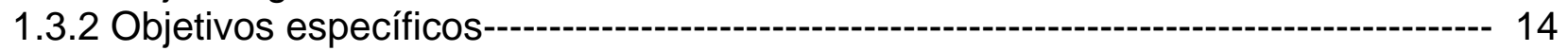

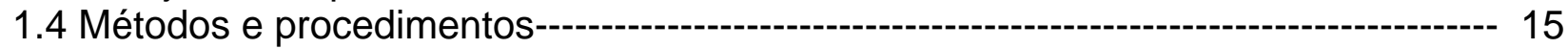

PARTE II

Fundamentação teórica e conceitual

CAP. 2 REDES ELETRÕNICAS DE COMUNICAÇÃO, das origens ao impacto na comunidade científica

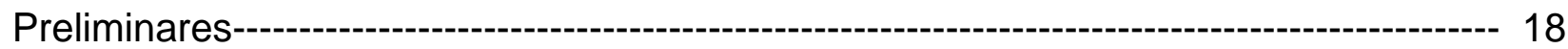

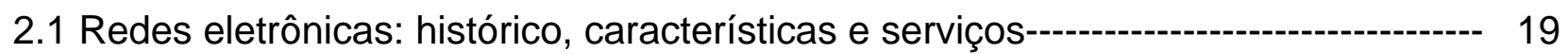

2.1.1 As redes eletrônicas no Brasil---------------------------------------------- 27

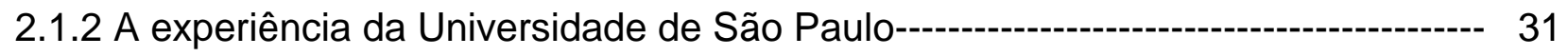

2.2 A comunidade científica face ao acesso a informação via redes eletrônicas-------- 34

CAP. 3 NECESSIDADES DE INFORMAÇÃO: das abordagens tradicionais ao novo enfoque metodológico

Preliminares-

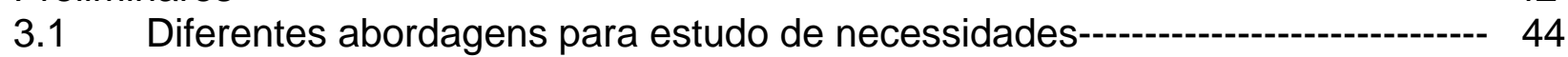

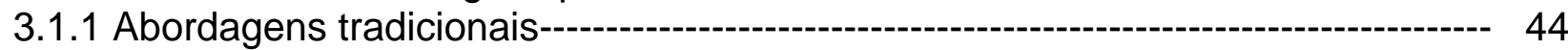

3.1.2 Novas abordagens de estudos de necessidades; ou abordagens alternativas-- 46

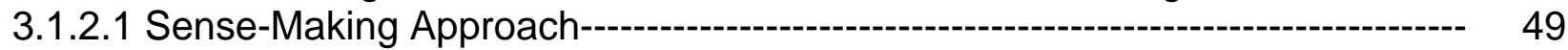


3.2 Ambiente de busca e uso da informação--_-

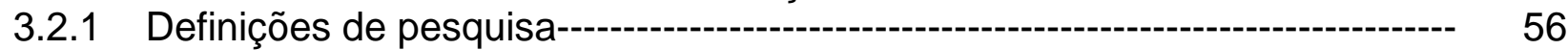

PARTE III

Estudo de Necessidades de Informação

CAP. 4 COMPORTAMENTO DE BUSCA E USO DA INFORMAÇÃO POR USUÁRIOS DA REDE LOCAL DO IFUSP

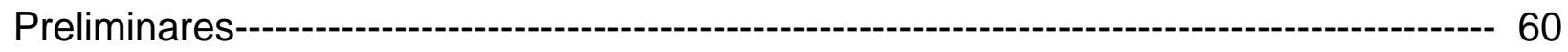

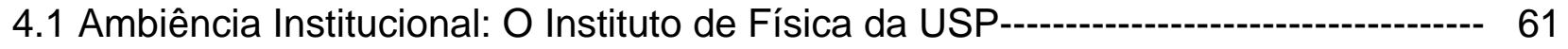

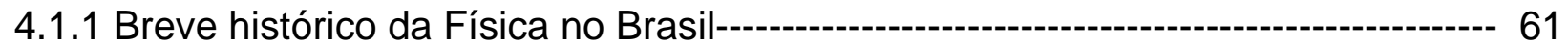

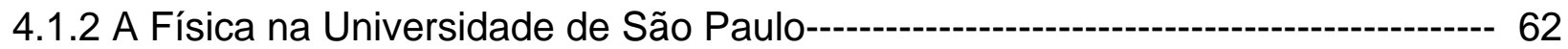

4.1.2.1 Processo histórico do pólo computacional do IFUSP-------------------------- 66

4.1.2.2 Participação do Serviço de Biblioteca e Informação do IFUSP------------------ 73

4.2 Pesquisa de campo: busca e uso da informação via redes eletrônicas-------------- 76

4.2.1 Paradigma adotado: base da pesquisa------------------------------------ 76

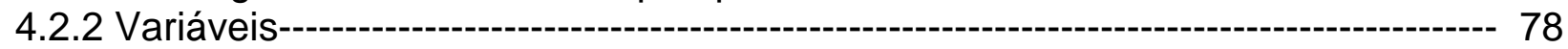

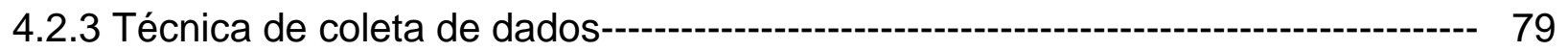

4.2.4 Instrumento de coleta de dados------------------------------------------- 81

4.2.5 Universo da pesquisa: comunidade de usuários da rede IFUSP------------------ 84

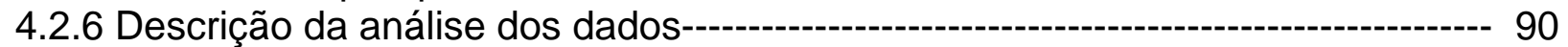

4.2.6.1 Análise de conteúdo / AC------------------------------------------- 90

\section{CAP. 5 ANÁLISE DOS RESULTADOS DA PESQUISA DE CAMPO}

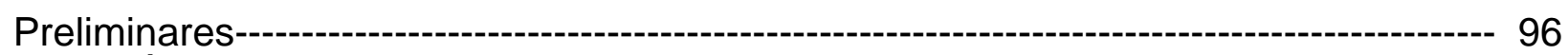

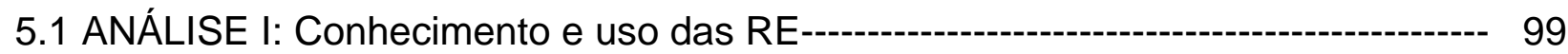

5.1.1 Experiência com computadores----o---- 99

5.1.2 Experiência com a DECNET, BITNET e INTERNET------------------------------- 100

5.1.3 Conhecimento e uso dos recursos das RE--------------------------------- 102

5.1.4 Participação em listas de discussão---------------------------------------------- 105

5.1.5 Propósitos de uso das RE---- 106

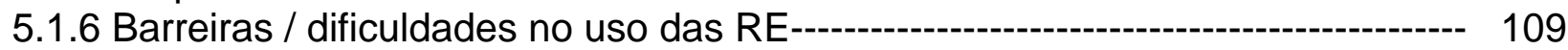

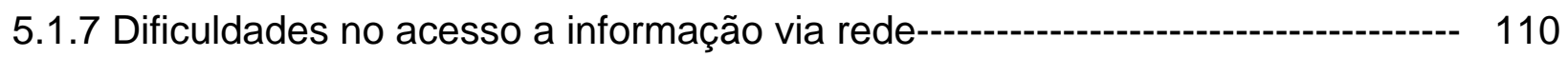

5.1.8 Treinamento para o uso das RE------------------------------------- 112

Obs.: não tem página 114 (erro de paginação)

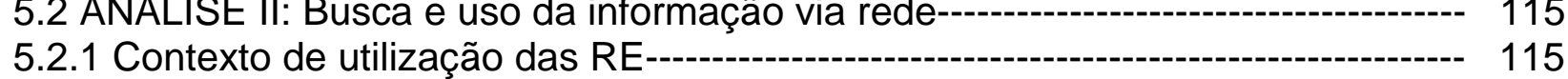

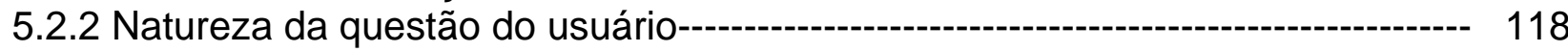

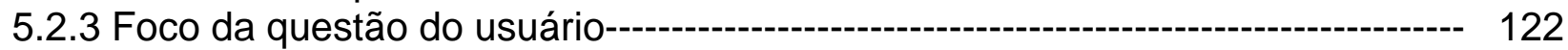

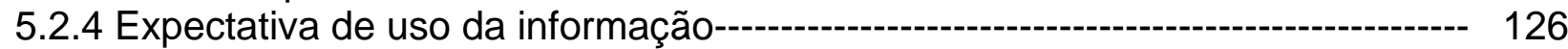

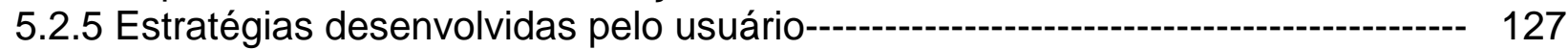

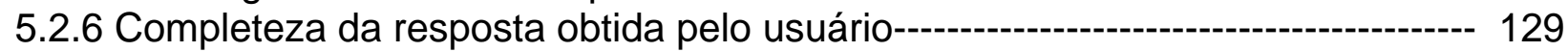

5.2.7 Satisfação com a resposta obtida------------------------------------------ 132 
5.2.8 Esforço dispendido na localização da resposta.................................... 135

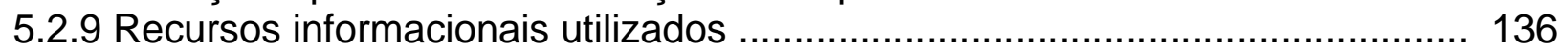

5.2 .10 Fontes de informação................................................................ 139

5.3 ANÁLISE III: Necessidades de informação não solucionadas.................... 140

5.3.1 Contexto de utilização das RE ........................................................ 140

5.3.2 Natureza das questões do usuário ........................................................ 142

5.3.3 Foco da questão do usuário ............................................................... 143

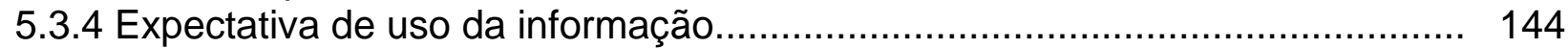

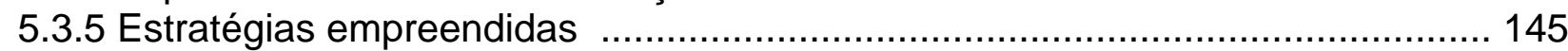

CAP. $6 \quad$ Considerações FINAIS ........................................................ 147

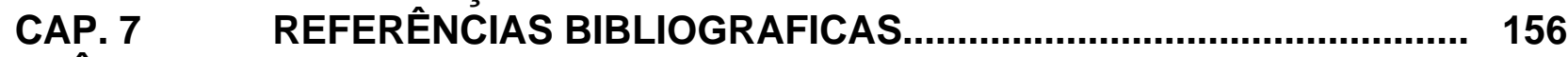

APÊNDICES

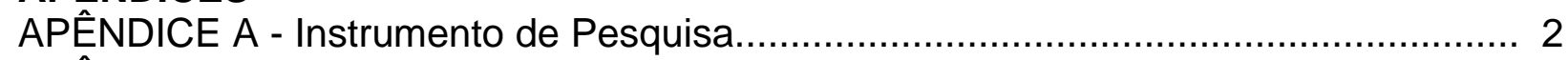

APÊNDICE B - Esquema das Análises de Conteúdo.......................................... 6

APÊNDICE C - Tabela - Uso dos recursos e serviços disponíveis na

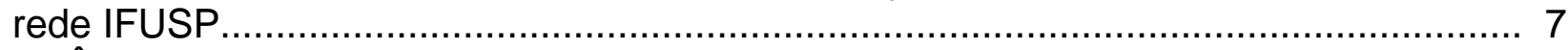

APÊNDICE D- Síntese do planejamento do instrumento de pesquisa -

Matriz: Variáveis de estudo $x$ itens do instrumento 
PARTE I

PLANO METODOLÓGICO 


\section{Capítulo 1}

\section{APRESENTAÇÃO DO ESTUDO}

E

PESQUISA

Apresentação do problema, escolha e justificativa do tema, objetivos, métodos e procedimentos. 


\subsection{REDE ELETRÔNICA e NECESSIDADE DE INFORMAÇÃO}

A realidade existe, mas não tem "sentido" só por existir. É o ser humano que Ihe confere sentido. Na verdade, produz sentidos. Ou seja, é passível de provocar vários sentidos conforme interpretações advindas de diferentes indivíduos.

Interpretar a realidade, tomá-la lógica, compreensível, significativa para o conjunto de indivíduos supõe o ato de "fazer sentido" ao mundo existente. Essa é uma das principais atividades humanas, senão a principal. É por seu intermédio que o ser humano compreende, analisa e interpreta todas as dimensões da realidade, captando e expressando essa totalidade de forma cada vez mais ampla e integral (MORAN, 1994).

Segundo PIOVESAN (1977, p.37), o termo "sentido" pode ser compreendido como: (a) a interpretação de uma palavra ou frase, (b) a significação, o significado. Esse mesmo autor conceitua "significado" como:

uma interpretação da significação de uma situação, ato, idéia ou objeto, com referenda a como se deve responder. A interação social e a organização social são possíveis pela existência de significados culturalmente compartilhados. Entretanto, a significação subjetiva do comportamento de outras pessoas para um ator (pessoa) e determinada por sua experiência pessoal passada, bem como pelos seus significados interiorizados, culturalmente definidos. Dai, o significado de uma situação social variar, em certa extensão, de uma pessoa para outras, inclusive na mesma cultura. Cada participante pode ter significados subjetivos que são únicos, mas, ao mesmo tempo, tem significados compartilhados que tornam a interação e a comunicação possíveis.

Algumas noções importantes podem ser depreendidas das definições acima. Uma delas refere-se ao fato de que o fluir do sentido, da percepção, e um processo à medida que envolve uma serie de procedimentos lógicos culminando com a atribuição de um "sentido". Este sentido, por sua vez, é o produto do processo. Outra idéia está relacionada ao fato de o indivíduo desenvolver tal processo, de acordo com um esquema ou quadro de referência interno, pré-estabelecido e respaldado em suas experiências anteriores, conhecimentos prévios e contexto sócio-cultural e profissional onde está inserido.

ROUSE e ROUSE (1984) mencionam que esses esquemas interiores são estruturados a partir de observações da realidade e também da observação de observações. 
feitas por outros. Nesses dois casos, as observações nunca são diretas e imediatas. Porque o ato de observação é mediado pela mente humana, a qual direciona o processo de seleção do que observar, como fazê-lo, e ainda interfere na interpretação final dos produtos da observação.

Isto posto, torna-se evidente que esses esquemas individuais pré-existentes são utilizados, quando necessário pelo ser humano. Porém sempre segundo objetivos determinados. Portanto, o que o indivíduo pretende fazer, aonde quer chegar, como e porque agir de uma ou outra forma também são fatores determinantes para a interpretação da realidade, para o processo de Hei atribuir sentido.

O ser humano move-se na vida questionando, encontrando barreiras, deparando-se com dilemas, envolvendo-se em confusões, sonhando, indo à procura de algo, lidando com desordens, passando o tempo, descansando, recuperando-se ou buscando felicidade. Isso dentro de uma realidade, a qual, segundo CARTER (1980), e repleta de descontinuidades. Descontinuidade entre a realidade e os "sensores" humanos, entre os sensores e a mente, entre a mente e a "língua", entre a língua e a mensagem criada, entre a mensagem criada e o canal utilizado, entre um ser humano agora e o mesmo daqui a instantes, entre diferentes seres humanos no mesmo intervalo de tempo, entre seres humanos e cultura, entre seres humanos e instituições, entre duas ou mais instituições, entre duas ou mais nações, e assim por diante. Descontinuidade e uma constante assumida da natureza em geral e da condição humana especificamente.

Para a garantia de sua movimentação contínua frente a essa realidade permeada de descontinuidade, o ser humano lança mão do uso contínuo dos já mencionados esquemas interiores. As transformações materializadas no uso sucessivo de esquemas são movidas pela existência de questões surgidas a partir do esgotamento dos esquemas presentes. À medida que esses esquemas se tornam inoperantes, a busca de novos se impõe. Tal busca esta associada à informação.

DERVIN, NILAN e JACOBSON (1981, p.808) conceituam a informação como um produto da observação e a observação como uma atividade necessária para se tratar com as descontinuidades percebidas no tempo e no espaço. A informação é conceitualizada como o sentido criado em um momento específico no tempo e no espaço por um ou mais indivíduos (DERVIN, 1992, p.65). Não é vista como alguma coisa que existe a parte das atividades do comportamento humano, mas sim como um dado ao qual o indivíduo proporciona vida, correlaciona, analisa, cria e confere sentido, incorporando essas novas informações aos seus esquemas interiores, alterando-os e atualizando-os constantemente.

Embora exista um contínuo debate entre teóricos em Filosofia, a idéia de que Informação e a visão perceptiva global do ser humano são construídas pelo próprio 
Indivíduo tem causado recentemente enorme impacto nas várias disciplinas envolvidas com processamento de informação, tais como: psicologia cognitiva, ciência cognitiva, pesquisas sobre memória, teoria do discurso e leitura, teorias de percepção (COLE, 1994). Para isso, também favorece o surgimento de novos paradigmas, tanto nas Ciências da Comunicação como na Ciência da Informação.

Durante muitos anos, a comunicação foi genericamente associada a duas idéias básicas. A primeira entende a comunicação como as "estruturas" envolvidas no processo, ou seja: canais, tecnologias e entidades (pessoas e instituições). Essas estruturas são intituladas por alguns autores como os "WHO I QUEM" da comunicação. A segunda idéia se refere ao conteúdo, ao material simbólico incorporado às mensagens que estão sendo enviadas pelos comunicadores - são os "WHAT I O QUE" da comunicação. Porém, uma terceira idéia se impõe e está relacionada prioritariamente com o "HOWI COMO" da comunicação. Isto é, com o produto final da mensagem enviada pelas fontes através de canais: a transformação desejada ou inesperada que pode (ou não) ter ocorrido no receptor (DERVIN e CLARK, 1989, p.5). Ou seja, o sucesso ou fracasso da comunicação está fortemente relacionado à atividade do receptor de perceber e compreender o que esta sendo transmitido.

De LOPES (1993, p.79), obtém-se uma abrangente reflexão sobre as principais correntes teórico-metodológicas que vem marcando atualmente a pesquisa de recepção dos meios de comunicação de massa. Em uma breve retrospectiva histórica, vê-se que estudos na década de 30 e 40 já abordavam esse tema. Mas mesmo conciliando uma visão qualitativa da recepção com a ação dos meios, os trabalhos sobre a audiência daquela época ainda se apoiavam na hipótese do indivíduo concebido como "receptor puro", exposto a irradiação do meio, cuja ação deveria ser cada vez mais dominada pelos criadores, programadores e operadores. OROZCO (1991) considera que tal concepção se insere no âmbito de uma abordagem tradicional da recepção.

Nos anos 60, estudos passam a se centrar nas intenções do receptor, introduzindo a idéia de uma atividade de escolha e de engajamento deste. A pergunta corrente era: O que os indivíduos fazem com os meios?

Já na década de 70, as pesquisas - refletindo a recepção dos meios a partir do modelo reducionistas dos efeitos, integrando a produção e a recepção da mensagem massiva a um quadro semiológico - acabam por colocar a recepção como prática complexa de construção social de sentido. Ainda OROZCO (1991, p.29), nessa perspectiva, entende que "o receptor não se depara com o meio de comunicação trazendo a mente vazia, mas sim repleta de atitudes, idéias e valores - "repertório cultural" que coloca em jogo com os repertórios propostos nas mensagens envolvidas na comunicação." 
A partir de então, o processo de comunicação é concebido como uma articulação de práticas de significação num campo de forças sociais. Práticas essas não aleatórias, mas enraizadas em um corpo de conhecimentos e nas estruturas de sentido, disponíveis numa sociedade determinada, ou através de regras do fazer profissional e das especificidades de cada meio de comunicação (LOPES, 1993).

Hoje, é comum encontrar autores de posições teóricas diversas concordando que a importância atual das pesquisas de recepção resulta de confluências na evolução da pesquisa de comunicação articuladas com importantes mudanças nas Ciências Sociais e nas Humanidades em geral. Ainda, reportando-nos a LOPES, (1993) nesta corrente de pesquisa atual, os processos colocados em movimento pelos receptores na sua prática com os meios são cada vez mais considerados como processos perceptivos, cognitivos, afetivos, relacionados com base na intencionalidade visando produzir significações e sentido para suas ações ${ }^{1}$.

Tanto quanto nas Ciências da Comunicação, o novo enfoque dado ao receptor teve impacto bastante evidente na Ciência da Informação. A literatura especializada da área também aponta o desenvolvimento de estudos voltados inicialmente para o Who, passando pelo what e adentrando ao how, a partir da década de 80 , quando se percebe crescente aumento do uso das teorias da comunicação.

Nessa área, a abordagem tradicional coloca a informação como externa, objetiva, alguma coisa que existe fora do indivíduo. È a mensagem transmitida pelo emissor (serviço de informação, biblioteca, catálogo) para o receptor (usuário) através de um canal, e a mensagem é informativa no sentido de que reduz ambigüidade ao reduzir simultaneamente o número de mensagens alternativas que poderia ser enviada. Informação, nesse contexto tradicional, existe em um mundo ordenado, capaz de ser descoberta, definida e medida. Pontos importantes desconsiderados nesta abordagem são que: o conhecimento não é absoluto; que as pessoas mudam e a mensagem enviada não é idêntica à recebida (MORRIS, 1994).

Nessa perspectiva, os usuários da informação são vistos apenas como um dos integrantes do sistema, mas não como a "razão de ser" do serviço. E aquele usuário "ideal", comparado por DERVIN (1983b, p. 160) e POPPER (1972, p.3), a um "carrinho vazio" que devera ser preenchido com "tijolos" pré-determinados e fornecidos pelos sistemas de recuperação, intitulados informação. Isto e, uma dada informação serve a diferentes usuários da mesma forma.

Tal situação ocorre porque, historicamente, os sistemas de informação tem sido planejados em função das tecnologias utilizadas para sua implementação, ou do 
conteúdo da informação a ser inserida. Os mais antigos sistemas encontraram suas bases nos documentos impressos, catálogos e hoje nos artefatos digitais, computadores e tecnologias associadas. O que esta inserido no documento, ou o que esta estocado no computador, e percebido como "conhecimento" ou "informação", e isso tem sido o determinante dos modelos dirigidos a tecnologia. Já modelos de conteúdo, derivados da classificação tradicional do conhecimento, vêm sendo constantemente acrescido de novos esquemas, índices, thesaurus e outros, visando prioritariamente o tratamento técnico do "conteúdo" do documento ou da informação.

Segundo MAEMULLIN e TAYLOR (1984), esse contexto tem estabelecido não somente um modo para organizar, mas também para disciplinar e reconhecer o próprio conhecimento. Dois aspectos importantes nesta organização tradicional do conhecimento são questionados: (a) a irrelevância dada a possíveis incongruências entre o que está contido no problema do usuário e o que está contido na pergunta por ele formulada e, principalmente, (b) a falta, nos sistemas de informação, de mecanismos para identificar como o usuário pretende usar a informação e quais são suas definições sobre relevância da informação.

O usuário tem sido colocado na posição passiva de ter que se adaptar aos mecanismos dos serviços de recuperação da informação, ao invés de amoldar esses mecanismos às suas características particulares. Soluções alternativas para esses problemas são os treinamentos que os sistemas procuram proporcionar aos usuários e, mais recentemente eclodindo os tão propagados sistemas conhecidos como amigáveis (userfriendly). "Segundo GLUCK (1992, p.78), intitular produtos operacionalmente como amigáveis" somente significa que são usáveis, não que satisfaçam as expectativas ou resolvam as necessidades de informação dos usuários.

Em 1978, COELHO NETTO (1978, p.30) cunhou essa estrutura de "paternalista", por pressupor que o processo de comunicação em uma biblioteca e todo orientado a partir da fonte (biblioteca) para o receptor (usuário). Isto denota uma visão unilateral do processo comunicativo, no qual a mensagem é produzida pela fonte e para o receptor. A fonte surge assim como ponto de partida de todo o processo, produzindo informações a sua vontade, e levando-as ao receptor - cujo único papel, inteiramente passivo, é receber essas informações produzidas longe de seu próprio campo de ação, ou, no mínimo, nos horizontes desse campo.

Sistemas de informação organizados nessa perspectiva tradicional concentram-se prioritariamente na aquisição e administração de grandes coleções de materiais. Assumiu-se durante décadas que as atividades técnicas dos sistemas eram o seu ponto nevrálgico. Considerava-se que os usuários utilizavam o sistema exatamente da 
maneira como estes tinham sido projetados. Não se imaginava indagar, aos sistemas, questões imprescindíveis sobre a identidade e propósitos principais de seus usuários.

Resulta desse procedimento que hoje em dia se conhece muita coisa sobre planejamento, aquisição, organização, controle e desenvolvimento de coleções, mas muito pouco sobre como as pessoas fazem uso dos sistemas ou para que fins, e como a informação - que e a matéria prima dos sistemas - esta sendo utilizada.

DERVIN, em 1977, mencionou uma estimativa de que 90\% das pesquisas e estudos em bibliotecas tinham como foco principal a própria instituição e suas atividades, e quando algum foco recaía sobre o usuário era a partir desse contexto (DERVIN, 1977, p. 17). Revisões da literatura publicadas pelo Annual Review of Information Science and Technology I ARIST mais recentemente mostram que boa parte dos estudos na área ainda seguem essa linha tradicional (DERVIN e NILAN, 1986; HEWINS, 1990). Salvo esparsas contribuições teóricas na literatura nacional, o Brasil ainda continua desenvolvendo pesquisas também dentro dos conceitos tradicionais.

Obviamente, grandes contribuições são advindas desses estudos.

Numerosos sistemas de catalogação e indexação foram desenvolvidos visando melhorar a recuperação da informação. Acesso a inúmeras bases de dados bibliográficos, não bibliográficos e de textos na íntegra estão disponíveis. Pode-se até mesmo afirmar que o usuário não foi completamente ignorado pelos sistemas. Muitas pesquisas enfocam suas apreciações e avaliações dos serviços. Criteriosos métodos de divulgação e treinamento para o uso dos serviços implementados foram também desenvolvidos visando sanar dificuldades e divulgar melhor os serviços.

Porém, a natureza das pessoas, como elas agem; a natureza da informação, como ela auxilia; tornam-se as questões nevrálgicas aos estudos recentes. O necessário, hoje, não é simplesmente alterar o foco das pesquisas, estudos e avaliação dos sistemas. Exige-se uma mudança mais profunda. Mudança, na verdade, na maneira como os profissionais da área visualizam a natureza dos seus serviços. Segundo ZWEIZIG e DERVIN (1977), o ponto crítico deixa de ser quem usa sistemas de informação e com que freqüência, e passa a ser com que propósitos os sistemas são utilizados e como eles ajudam. Complementam dizendo que somente assim se começara a pensar em termos de necessidades de informação e usos da informação.

Enquanto os estudos passados - centrados no sistema - eram definidos em bases sociológicas, observando-se grupos de usuários (por exemplo: químicos e físicos; universitários e escolares; criativas as e adultos; negros e brancos), atualmente as pesquisas estão centradas no indivíduo, partindo de uma perspectiva cognitiva, buscando interpretar necessidades de informação tanto intelectuais como sociológicas. Análises estão sendo feitas sobre as características únicas de cada usuário buscando chegar as 
cognições comuns a maioria deles. O objetivo é obter subsídios para o desenvolvimento de interfaces dinâmicas que possam adaptar-se aquelas características únicas.

A partir da década de 80 , estudos dessa natureza - conhecidos como abordagens da percepção ou alternativas - começam a considerar que a informação só tem sentido quando integrada a algum contexto. É um dado incompleto, ao qual o indivíduo atribui um sentido a partir da intervenção de seus esquemas interiores. Completando a metáfora proposta por DERVIN (1983b, p. 168), a informação não mais se configura como "tijolos" colocados uns sobre os outros, mas sim como a "argila" à qual o próprio indivíduo dará o formato, a consistência e o sentido que Ihe convier.

Quanto aos usuários, esta nova abordagem concebe os indivíduos como pessoas com necessidades cognitivas, afetivas e fisiológicas fundamentais próprias, e que operam dentro de esquemas que são partes de um ambiente com restrições socioculturais, políticas e econômicas. Essas necessidades próprias, os esquemas e o ambiente formam a base do contexto do comportamento de busca de informação. Os mais importantes atos de comunicação - questionar, planejar, interpretar, criar, resolver, responder, tão esquecidos no modelo tradicional - são amplamente valorizados no modelo alternativo (DERVIN, 1989).

Um ponto bastante relevador a ser considerado, a partir do que foi exposto, e o fato de as necessidades de informação mudarem no tempo e dependerem do indivíduo que a busca. Assim, os sistemas de recuperação da informação devem ser flexíveis o suficiente para permitir ao usuário adaptar o processo de busca de informação à sua necessidade corrente.

BROWN (1991) enfatiza que, compreendendo os comportamentos de busca de informação mais profundamente, poder-se-d capacitar as organizações provedoras de informação à melhor servir as necessidades de seus clientes, aumentando assim a eficiência específica dos indivíduos nos meios pessoais, sociais, e profissionais. O ideal seria alcançar o conceito global para uma dada comunidade, usando classificações abrangentes, em que todas as situações individuais pudessem ser enquadradas. Se esse conceito global for construído dentro dos sistemas atuais de informação, com certeza mais pessoas se beneficiarão dele.

A lógica básica por trás dessa perspectiva centrada no usuário e que os sistemas de informação devam ser modelados de acordo com o usuário, com a natureza de suas necessidades de informação e com seus padrões de comportamento na busca e no uso da informação, de modo a maximizar sua própria eficiência. Portanto, os sistemas nunca devem ser baseados apenas na ótica dos projetistas, analistas de sistema e mesmo dos cientistas da informação. Isso se torna particularmente evidente quando se lembra que, segundo ROUSE e ROUSE (1984), sistemas de informação são quase sempre 
projetados para auxiliar tomada de decisão e solucionar problemas dentro de um contexto particular.

MAEMULLIN e TAYLOR, já em 1984, chamavam atenção sobre o fato. de que a sociedade se torna cada vez mais dependente da informação. Mas os sistemas que estocam, organizam e tornam acessíveis a informação e o conhecimento criam problemas crescentemente críticos. Segundo esses autores, uma questão seria na era da informação e a sobreposição da informação. Entende-se por isso que não dispomos de informação em demasia, mas, ao contrário; que esses mesmos sistemas que filtram, transmitem e distribuem informação não estão operando bem, isto é, não estão operando segundo as necessidades dos usuários. Avanços na tecnologia de computadores, tanto em termos de custos como de performance, tem resultado na projeção e desenvolvimento de sistemas de informação em uma ampla variedade de domínios. Alguns desses sistemas são úteis, mas em geral suas utilidades têm sido limitadas diante do fato de enfatizarem mais a engenharia de software do que a engenharia humana.

A explosão da informação eletrônica tem aumentado o acesso à informação de todo tipo, através de computadores, no trabalho ou em casa. As tecnologias idealizadas na década passada, suas intercomunicabilidades e integração, tornam-se agora realidade. Um artigo de capa da revista "USA Today" (Nov. 19, 1992) indica que os canais de televisão em que o receptor recebe passivamente as informações estão sendo alterado para canais multimídia, com TV interativa, vídeo sob comando, navegador de assunto e outras tecnologias. Tais sistemas integram hipertexto e imagens, fornecendo informações sobre tópicos diversificados e em diferentes formatos. É certo que informação personalizada, individualizada, tornar-se-á diretamente disponível para indivíduos muito em breve. Sistemas de informação e bibliotecas, conseqüentemente, serão forçados a mudar seus paradigmas de base se quiserem continuar a ter espaço para a difusão de informação. Uma opção e reerguer tais sistemas de modo a reconhecer a centralidade do indivíduo e compreender a natureza mutável da informação (MORRIS, 1994).

LANCASTER, em 1978, já previa a substituição do sistema baseado em fontes impressas por volta do ano 2000. Essa mudança vem causando enorme impacto na ciência, na sociedade e no mundo como um todo. VARGAS (1994, p.7), Ministro da Ciência e Tecnologia no Brasil, menciona que:

o mundo científico e tecnológico, atualmente, desfruta de facilidades que possibilitam aos seus integrantes o acesso e a troca de informações de forma segura, ágil e flexível. Este avanço se realiza em função da crescente evolução da tecnologia, principalmente no que se refere à eletrônica, computação e telecomunicações. O aproveitamento e integração das tecnologias geradas no âmbito dessas três áreas têm permitido o desenvolvimento das redes de computadores, chamadas redes eletrônicas. 
Dentre as inúmeras redes existentes, destaca-se a Internet, por promover a integração da maioria delas e por oferecer uma grande variedade de produtos e serviços de informação.

Surgida nos EUA há cerca de 20 anos, a Internet e uma rede virtual, voltada principalmente para as áreas acadêmicas e de pesquisa, que dissemina experiências e informações sobre variadas áreas do conhecimento, entre milhões de usuários das mais diferentes origens e estilos de vida. Apresentando crescimento exponencial, tem conectado atualmente não só os principais laboratórios de pesquisa e universidades, como também faculdades menores, bibliotecas e escolas secundárias ligadas a mais de 5000 redes espalhadas por cerca de 50 países nos cinco continentes.

O Brasil, através da RNP, Rede Nacional de Pesquisa, integrou-se oficialmente a Internet em fins de 1989, e conta atualmente com mais de 500 instituições de ensino e pesquisa, em 22 estados da União, com mais de 7000 computadores hosts e 50000 usuários (VARGAS, 1995). Embora bastante recente essa participação, percebe-se um desenvolvimento acentuado dentre as várias universidades brasileiras, com muitos recursos informacionais nacionais disponíveis e, diversos serviços sendo oferecidos dentro dos mais modernos e recentes padrões tecnológicos.

Inicialmente estabelecida com o fito único de compartir recursos computacionais, logo começou a evoluir para algo mais do que um instrumento científico, proporcionando a seus usuários, com eficiência e rapidez, acesso a fontes inesgotáveis de informação. Elas interconectam usuários para os mais variados fins e tem contribuído para ampliar e democratizar o acesso a informação, eliminando barreiras como distância geográfica, fuso horário, hierarquia e outras.

As redes são, hoje, local tanto para se buscar, disseminar e recuperar informações, como para o desenvolvimento de atividades de pesquisa, ensino, comércio, indústria, lazer, sociais e outras. Através delas se encontram disponíveis e acessíveis, diretamente na escrivaninha do usuário, quantidade imensurável de informação, o que pode estar facilitando sua busca e uso, tanto quanto Ihe conferindo maior rapidez no acesso, constante atualização dos fatos e grande economia de tempo e dinheiro.

Essa realidade, com certeza, está se refletindo na comunidade científica, provocando mudanças de comportamento quanto aos comportamentos de busca e uso da informação, no desempenho de pesquisa, ensino, intercâmbio de conhecimento, na competição de profissões, industrias e outros afazeres do homem moderno.

O papel que a rede eletrônica vem desempenhando nesse contexto e o de propiciar um novo meio para o estabelecimento de interligações entre os vários sistemas de informação existentes, redimensionando a importância dos diversos canais de 
comunicação, de uma forma mundial. Um novo e mais adequado ambiente para proliferação de idéias se encontra disponível (a Internet).

Mas, saber onde encontrar a informação disponível, como perseguir. termos de pesquisas e delimitar estratégias de buscas acertadas nesse grande emaranhado de recursos informacionais disponíveis e realmente uma tarefa importante, necessária e nem sempre fácil.

Torna-se imprescindível que sejam desenvolvidos estudos junto á comunidade de usuários dessas redes, no sentido de se identificar, mapear e diagnosticar como tem sido o processo de busca e uso da informação nos variados ambientes em que se insere, tais como universidades, empresas, institutos de pesquisas, firmas, industrias, instituições governamentais, comerciais entre outros. E premente que cada vez mais se voltem os olhos aos procedimentos desenvolvidos pelo receptor da informação em seu processo de compreensão e inferência do sentido da realidade.

Revendo mais particularmente, a figura dos usuários de redes, percebe-se que várias habilidades e conhecimentos Ihe são exigidos para que, realmente, se beneficiam delas. É crucial saber controlar e navegar em toda a sua estrutura organizacional, desde a rede de seu próprio local de trabalho para, posteriormente, compreender a estrutura das redes regionais, estaduais, nacionais, terminando pelas internacionais. Somente esse conhecimento global, com satisfatória percepção das nuances de cada ambiente, fornecerá ao usuário uma visão macro capaz de facilitar suas interações com o sistema. Isto sem dúvida o levara, também, a realizar adequados procedimentos de pesquisas e recuperação da informação. Porém, dada a transparência das RE e \& falta de constantes programas de treinamentos, tais conhecimentos não parecem estar ainda sob controle para muitos integrantes de vários sistemas.

A análise do comportamento dos usuários em relação às redes eletrônicas de comunicação, como um recurso informacional a mais dentro de sua própria instituição, pode representar grande avanço para a adequação de seus sistemas, para o desenvolvimento de novos produtos e serviços, levando profissionais da informação documentária à profunda reflexão sobre o papel das redes quanto à disseminação da informação e o papel renovado das bibliotecas, centros de documentação e similares

nesse novo contexto.

E hora e vez de lan9ar questões como: - Para quais propósitos a rede eletrônica tem sido utilizada? - Como vem efetivamente auxiliando os indivíduos? -

De que forma os indivíduos estão buscando informação nesse novo ambiente?

Considerar como os usuários utilizam as redes eletrônicas para sanar suas necessidades informacionais, quais suas expectativas, problemas e barreiras são as preocupações desta pesquisa. Trata-se de um estudo do comportamento de busca e uso da 
informação via RE, desenvolvido na Universidade de São Paulo (USP), mais especificamente no Instituto de Física (IFUSP). Para tanto, É utilizado como respaldo metodológico um dos atuais paradigmas alternativos de estudo de necessidades de informação, qual seja: 0 Sense-Making Approach desenvolvido pela educadora norte americana Brenda Dervin (1983).

Partindo do mapeamento e análise de sua rede eletrônica local (estrutura física, conexões com as redes nacionais e internacionais, serviço, recursos e produtos disponíveis) e seguido da interpretação de suas funções dentro do contexto universitário e acadêmico em foco, foi desenvolvida pesquisa peculiar de campo junto aos usuários, respaldada nos novos pressupostos de revalorização do receptor da informação.

\section{ESCOLHA E JUSTIFICATIVA DO TEMA}

O conhecimento feito de modo sistemático para detectar necessidades informacionais e comportamento de busca e uso de informação do público-alvo e a chave primordial dos estudos de necessidades a fim de alcançar o sucesso de todo e qualquer serviço de informação. Como chegar a esse conhecimento tem sido nossa preocupação desde quando atuávamos como profissional de bibliotecas, refletindo-se ainda por ocasião do mestrado c culminando agora com esta tese de doutorado.

Atuando em atividades que envolvem, especificamente, as tecnologias de comunicação eletrônica, tornou-nos clara a necessidade de se estudar o impacto de tal tecnologia nos padrões de comportamento de busca e uso da informação entre usuários de redes locais junto às universidades brasileiras.

Esparsas pesquisas tem sido desenvolvidas em nível internacional no sentido de se analisar e estudar os usuários e suas necessidades informacionais nesse atual ambiente de redes. Justificando ainda mais o fato de ser assunto emergente, de vital * $f$ importância para o desenvolvimento científico e tecnológico. A literatura atual indica que a preocupação dos autores recai na evolução e desenvolvimento tecnológico das redes, mas pouco ainda se tem contribuído quanto a estudos sobre o real impacto das mesmas na comunidade científica e mesmo na sociedade, particularmente no que se refere a America Latina.

Nesse contexto, este trabalho pretende contribuir com reflexões e análises das necessidades de informação, em comunidade acadêmica, na utilização de redes eletrônicas. Define-se como objeto de pesquisa o comportamento de busca e uso da informação por usuários da rede eletrônica do Instituto de Física da USP (IFUSP). 
Este grupo foi selecionado por vários motives: (a) por ser rede pioneira, / bem equipada e instalada, contando com equipe de trabalho e assistência técnica de alto nível, fornecendo inclusive apoio a outras universidades nacionais e instituiß5es. internacionais, (b) seu Centre de Computação vem oferecendo, já ha algum tempo, diversificados serviços de informação via rede e, (c) o Serviço de Biblioteca e informação vem também implementando várias atividades eletrônicas para atendimento dos usuários.

As pretensões deste estudo são teóricas e empíricas buscando-se conhecer a realidade, o status-quo do grupo estudado, e não, necessariamente, pretende inferir soluções praticas.

\subsection{OBJETIVOS}

\subsubsection{Objetivo Geral}

Evidenciar necessidades de informação de comunidade universitária para melhor compreensão do papel das redes eletrônicas nas atividades de ensino, pesquisa e extensão, utilizando a abordagem do Sense-Making

centrada no usuário.

\subsubsection{Objetivos Específicos}

* Sistematizar conhecimentos sobre redes eletrônicas para evidenciar sua evolução em nível intencional e nacional.

* Revisar estudos de necessidades de informação nas linhas tradicionais e alternativas.

* Adaptar a abordagem Sense-Making para estudar o comportamento de usuários de redes eletrônicas quanto à busca e uso da informação.

* Analisar condutas de busca e uso da informação de comunidade universitária da USP, particularmente no Instituto de Física, determinando perfil de necessidades informacionais. 


\subsection{MÉTODOS E PROCEDIMENTOS}

Partindo de revisões de literatura nas temáticas mencionadas anteriormente, tencionase identificar possíveis relações entre as vantagens oferecidas pelas redes eletrônicas e necessidades informacionais.

Com isso, desenvolve-se o estudo de comportamento dos usuários, de modo a buscar evidências que comprovem ou não as relações detectadas. Foi selecionado, como população de estudo, o grupo de usuários da rede local do Instituto de Física, por estarem vinculados a uma das redes locais melhor estruturada do campus da USP, apresentando nível de prestação de serviços de alta qualidade e, portanto, com perspectivas de resultados mais específicos.

Novas indagações surgem a cada momento: - Estão esses usuários conscientes de todas as disponibilidades de acesso a informação existentes nas redes? Recorrem eles a rede para buscar e usar informação? - De que maneira isso vem ocorrendo? - com que objetivo recorrem à rede? - Que tipo de problemas buscam solucionar através da rede? Quais auxílios esperam receber via rede? - Como tem utilizado a informação eletrônica?

Visando responder a todas essas perguntas, buscou-se na literatura subsídios para se estruturar o estudo das necessidades de informação daquela comunidade acadêmica. Dentre as várias possibilidades identificadas, optou-se por empreender um estudo qualitativo, voltado a percepção individual de cada membro da comunidade selecionada, observando-se os tipos de personalidades, isto $d$, os diferentes estilos cognitivos - sujeito ativo internamente em contraposição com o ativo externamente, sistemático ou intuitivo, criativo ou menos criativo, etc. Espera-se, assim, chegar à visão global das características comuns aquela população.

O Sense-Making Approach foi selecionado pelas seguintes razoes: (a) apresentar um método complete, bastante eficiente e 16 gico para o mapeamento das necessidade de informação sob a 6tica do usuário; (b) tratar-se de um método ainda inédito na literatura nacional, inexistindo relates tanto em nível de trabalhos teóricos como de aplica9oes práticas e, (c) finalmente, por esta pesquisadora ter tido a oportunidade de participar de projeto de pesquisa em conjunto com o Prof. Dr. Michael Nilan da Syracuse University (especialista na técnica Sense Making), o que motivou e ampliou horizontes para aplicação de tal metodologia. 
PARTE II

\section{FUNDAMENTAÇÃO TEÓRICA \\ CONCEITUAL}




\section{Capítulo 2}

\section{REDES ELETRÔNICAS}

Das origens ao impacto na comunidade científica

Histórico, características e funções das redes ARPANET,

BITNET e INTERNET. Desenvolvimento da rede acadêmica brasileira. Experiência da Universidade de São Paulo. Impacto dessa tecnologia na comunidade científica. 


\section{PRELIMINARES}

Adotando a definição de VIEIRA (1994, p.29), entende-se por rede "um conjunto de sistemas de comunicação e/ou informação - descentralizados, intercomunicantes, formados por unidades funcionais independentes, com serviços e funções interrelacionados - cuja interação e presidida por acordos de cooperação e adoção de normas comuns".

As redes podem ser estruturadas tanto em função dos aspectos tecnológicos (hardware e software), como sob a ética de sua funcionalidade e de seus propósitos.

Quanto aos aspectos tecnológicos, tem sido classificadas conforme a tecnologia de comunicação utilizada, a organização topo!6gica e a distancia entre os nodos conectados. Podem ser redes do tipo LAN (Local-Área Network), quando são constituídas por computadores de porte médio e pequeno, interligados por pares tran9ados, cabos coaxiais ou fibras 6ticas, dentro de uma área limitada, quase sempre formando redes privadas. Ou redes do tipo WAN (Wide-Área Network), quando voltadas para aplica96es de interesse publico ou nacional a longa distancia, interligando computadores de maior porte ou redes, por meio de microondas, canais de satélites, freqüências exclusivas de rádio, ou ainda por meio de canais interurbanos ou interestaduais de fibra ótica.

Quanto à funcionalidade, podem ser agrupadas em:

(a) redes de comunicação de dados (exemplo. internacionais: BITNET, INTERNET; nacionais: RENPAC, ALTERNEX),

(b) redes de serviços e de apoio institucional a sistemas de informação (explo.: internacionais- RITLA, ISDS; brasileiras : BIBLIODATA, COMUT) e

(c) redes de informação especializada (exemplo: internacionais: INFOTERRA, INIS, AGRIS; brasileiras: EMBRAPA, PRODASEN, BIREME)

Esta pesquisa se restringe a sistematizar, discutir e analisar as redes de comunicação de dados, mais especificamente a BITNET e a INTERNET, tanto pela importância que tem junto à comunidade científica mundial, por sua abrangência intercontinental, como pela sua disponibilidade aos usuários brasileiros, em particular a comunidade acadêmica do Instituto de Fica da Universidade de São Paulo. 


\subsection{REDE ELETRÔNICA: HISTÓRICO, CARACTERÍSTICA E SERVIÇOS}

Segundo FREEMAN e ALLON (1986), redes de comunicação existem sempre que dois ou mais equipamentos de processamento de dados estejam aptos para a troca de mensagens entre si.

No conceito de rede, existe uma idéia simples: compartilhamento e otimização de recursos entre usuários de computador. Esses recursos podem ser:

- hardware (equipamentos diversos como microcomputadores, supercomputadores, laboratórios gráficos, impressoras, fax, Modem, entre outros);

- software (programas e aplicativos variados);

- fontes informacionais (como bases de dados, arquivos de textos eletrônicos, catálogos de bibliotecas, imagens, som e outros); e ainda

- recursos humanos (conhecimento e know-how de especialistas, profissionais e usuários em geral).

Em cada caso, ao invés de se duplicar ou transportar os recursos, eles são colocados a disposição do publico, conectando-os entre si, independentemente da situação geográfica do recurso ou do usuário. Embora a idéia seja simples, sua implementação e um tanto complexa. Conectar computadores, transferir dados e informações, com sucesso, requer uma série de regras e/ou normas próprias de comunicação, as quais são denominadas de protocolo2.

\section{ARPANET - $1^{\text {a }}$ tentativa de compartilhamento de recursos}

Aponta-se a origem das redes eletrônicas de comunicação em princípios de 60, com o estabelecimento das redes packet-switched - comutação de pacotes. Trata-se de um procedimento que fragmenta mensagens em partes menores, denominadas "pacotes", determina a rota3 de destino e, finalmente, reagrupa as partes. Esse

\footnotetext{
${ }^{1}$ Baseado no artigo de FERREIRA (1994b) em vias de ser publicado na revista Ciência da Informação. Parte do material didático elaborado como apoio a disciplina "Acesso a Informação via Redes Eletrônicas", oferecida no Curso de Pós-Graduação em Ciência da informação da ECA/USP no $1^{\circ}$ sem. 1994. Ministrada por essa pesquisadora e coordenado pela Prof. Neusa D. Macedo.

2 Protocolo e um conjunto de regras e comandos pre-estabelecidos entre os componentes de uma rede para que se efetuem suas comunica9oes, ou seja, para que os computadores envolvidos "falém" entre si. Os protocolos são geralmente documentados em paginas e paginas de material impresso, porém, como ocorre com tantas outras tecnologias complexas, o usuário não precisa conhecê-los em detalhes para que possa deles se utilizar (KROL, 1993).

3 "Rota" e o caminho definido por algum critério, normalmente baseado nas condi9oes operacionais da rede, que e usada pelo "software" de gerenciamento da rede para determinar como se atingir um determinado recurso (MORGADO, 1991).
} 
procedimento, segundo HARDY (1993), apresenta várias vantagens como o compartilhamento de uma conexão entre muitos usuários, envio de mensagens ininterrupta e, imediatamente, agilidade no manuseio dos pacotes e velocidade de transmissão entre outras.

A primeira rede a utilizar tal tecnologia foi operada pelos Nacional Physical Laboratories, no Reino Unido, em 1968, seguida de outra breve experiência de três anos da Societe Internationale de Telecommunications Aeronautiques, na Franca em 1969. Entretanto, somente quando o US Defense Department's Advanced Research Projects Agency (ARPA) lança mão dessa mesma tecnologia para estruturar a rede ARPANET, iniciase de fato a sua fundamentação e consolidação em estruturas de amplo alcance.

O objetivo inicial dessa rede era permitir o compartilhamento de recursos computacionais (tais como CPU), bases de dados e recursos gráficos entre as diversas organizações envolvidas em pesquisas, junto ao Departamento de Defesa Norte Americano.

A ARPANET utilizou o protocolo NCP/Network Control Protocol de 1969 at<5 1982 , quando e substituído pelo protocolo atualmente de cobertura universal, 0 TCP/IP = Transmission Control Protocol/Internet Protocol.

\section{BITNET - A REDE ACADÊMICA}

Enquanto a ARPANET foi o estágio inicial das atuais redes eletrônicas de comunicação em sua evolução, outra tecnologia desenvolvida concomitantemente também influenciou o crescimento desta. É a rede store-and-forward ou "armazena-e reencaminha", usada para transmissão de mensagens de correio. O serviço de correio eletrônico, por ser assíncrono (não-concomitante), impõe menos exigências sobre a rede. Em particular, podem ser utilizados canais de comunicarão de baixa capacidade e temporários (linhas discadas), pois isto não inviabiliza o serviço, apenas o torna mais lento (STANTON, 1993).

Com suporte dessa tecnologia, a BITNET (Because It's Time NETwork) foi estabelecida em 5 de maio de 1981 como rede cooperativa entre a CUNY (City University of New York) e a Yale University, ambas nos Estados Unidos. A combinação da tecnologia de correio eletrônico com a necessidade de comunicação no meio acadêmico estava madura o suficiente para se iniciar a comunicação via computadores entre aquelas universidades. Seu desenvolvimento foi tal que já em 1982, com o ingresso da Universidade da Califórnia, em Berkeley, EUA, torna-se continental. 
O início dessa rede foi marcada pela simplicidade e necessidade de se implementar os serviços o mais rapidamente possível. Como a maioria das universidades que se tornaram os primeiros nos da rede, estavam equipadas com computadores IBM, rodando sob sistema operacional VM/370, naturalmente deu-se a escolha do padrão IBM, bastante simples mas muito eficiente, o RSCS (Remote Spooling Communication Subsystem) como a base do sistema de comunicação da BITNET.

A sistemática adotada para seu desenvolvimento foi a de, com o mínimo custo, sem requisitos e restrições, proporcionar comunicação entre as mais diversas universidades, consolidando assim a essência do seu espírito cooperativo. A idéia central e dividir todos os gastos e responsabilidades entre os participantes. Cada um assume o custo de transmissão de todas as mensagens entre si e o próximo $\mathrm{no}^{4}$ da rede, independentemente de essas mensagens serem próprias ou estarem em transito ${ }^{5}$ e, principalmente, comprometendo-se a oferecer condições para que, no mínimo um novo membro, possa se conectar a rede através de sua ligação.

Atualmente, as instituições conectadas a BITNET são instituições de ensino superior, organizações relacionadas ou afiliadas a universidades, organizações sem fins-lucrativos, e instituições não educacionais com fins lucrativos (como por exemplo a IBM e a DEC).

Do ponto de vista do usuário, para que se tenha acesso á rede e seus serviços, basta que esse usuário seja cadastrado junto a um computador no da rede BITNET. Esse cadastramento implica na atribuição de um identificador ao usuário (useridentification ou user-id) e reserva de uma área de armazenamento ou caixa de correio ([mailbox], onde serão gravadas as mensagens eventualmente recebidas.

Utilizando as descrições dadas por MORGADO (1991), transcreve-se a seguir os serviços básicos disponíveis na rede BITNET:

\section{A) Correio eletrônico (Email)}

E o serviço mais simples e mais utilizado dentro da rede. O usuário digita uma mensagem no computador a que tem acesso, endereçando-a para o receptor, cujo endereço deve ter sempre a seguinte configuração:

$$
\text { user-id @ no }
$$

\footnotetext{
4"Nó" ou "node" e qualquer maquina ou sistema pertencente a uma rede, definindo um local (site) associado *a rede. Na representação gráfica de uma rede, os nos são os vértices dos polígonos resultantes (MORGADO, 1991).

${ }^{5}$ Diz-se em trânsito as mensagens originárias de outros nos, que passam seguindo sua rota de endereços.
} 
sendo user-id a identificação do usuário e no o "sistema usuário" ou host.. Exemplo: SMFERREI@CAT.CCE.USP.BR

A mensagem e transmitida através da rede para o computador hospedeiro de destine e colocada na área de armazenamento (mailbox) do receptor, o qual poderá acessá-la quando Hei for mais conveniente, lendo-a simplesmente ou ainda respondendo, descartando-a e/ou arquivando-a.

Além disso, dentro do correio eletrônico o usuário terem alternativas:

- pode pedir arquivos de domínio publico a um servidor localizado em nos da rede, por meio de mensagens;

- pode conectar-se a outras redes associadas à BITNET, ou com as quais ela tenha gateways ;

- e pode integrar-se as listas de distribuição (descritas mais a frente).

\section{B) Transferência de arquivo}

Por intermédio de programas do tipo File-Server, o usuário pode pesquisar diretórios de arquivos mantidos em outros locais remotos (sites) e requisitar cópias do que lhe interessar via correio eletrônico. Os arquivos podem conter documentos, artigos, rclat6rios, gravuras, mapas ou programas de computadores de interesse dos usuários da rede. Esse serviço, porém disponível apenas dentro da própria rcde BITNET, não pode ser utilizado para troca de arquivos com outras redes.

\section{C) Mensagens Interativas}

"' São definidas como textos curtos, de no máximo 110 caracteres, que são

trocados de modo sincrônico entre usuários da rede. Mensagens tratadas com altíssima prioridade, enviadas imediatamente.

A possibilidade de uso dessa modalidade de serviço está condicionada ao fato de o receptor estar conectado naquele exato momento, pois caso contrário a mensagem será perdida tendo em vista que as interativas não são armazenadas pelo sistema.

\section{D) Acesso a Bancos de Dados}

Alguns nos da rede mantém bancos de dados, contendo artigos, relatórios técnicos e outras informações científicas relevantes, passiveis de serem acessados via BITNET. Porém esse acesso não se dá interativamente, mas sim através do envio de mensagens ao servidor do Banco, o qual enviará, posteriormente, como correio ou transferência de arquivo, o material solicitado. 


\section{E) Sistemas de Quadro de Aviso}

Também conhecido como BBS (Bulletin Board Service), o sistema de. quadro de aviso permite que pessoas com interesses comuns troquem informações entre si. No computador que dá suporte ao Sistema, são armazenados mensagens, artigos e arquivos, possibilitando aos interessados a conexão e consulta quando de sua conveniência e interesse, podendo isso ser feito também para usuários conectados através de acessos discados (rede telefônica).

\section{F) Sistemas de Listas de Distribuição}

Através dos programas listservers ${ }^{6}$, são geradas as denominadas "listas de distribuição" que já somam centenas de serviços distribuídos dentro de suas muitas modalidades: Grupos de Notícias, Grupos de Discussão, Notícias etc.

O envio de uma simples mensagem a uma lista qualquer na BITNET resulta que esta mensagem e reproduzida e enviada a todos os assinantes daquela lista. Pessoas podem assinar ou cancelar a assinatura, bastando enviar uma mensagem para a listserv@nó, com o texto inglês Subscribe <list name> <nome e sobrenome>. Participando dessas listas, o usuário pode tornar-se um assíduo debatedor dos problemas e temas surgidos na lista, colocando sempre suas opiniões na rede ou, simplesmente, tomando a atitude de observador/leitor (conhecido na rede como lurker), sem se manifestar a respeito.

\section{G) Outros serviços}

Existem alguns sistemas instalados em nos principais, como por escapelo na CUNY (City University of New York) e nos principais nos europeus, que proporcionam serviços de informação adicionais, incluindo: informações gerais sobre a rede, topologia, nos e nomes conectados; "dicas" sobre como utilizar a rede; identificadores de usuários e endereços de nos; dados sobre outras redes conectadas a BITNET.

\section{INTERNET - a rede das redes}

Como já mencionado, a tecnologia Internet foi desenvolvida inicialmente pelo Depto. de Defesa Norte Americano (para fins militares), sendo depois largamente

6"Listservs" são softwares que, através de comandos específicos, organizam as listas de endereço dos participantes de uma Lista ou Grupo de Discussão e distribuem automaticamente copia de todas as mensagens a cada um desses integrantes 
adotada no mundo todo, tornando o protocolo TCP/IP o padrão "de fato" das atuais redes.

O sucesso representado pela ARPANET motivou a comunidade acadêmica norteamericana a estruturar sua própria rede, o que foi feito na década de 80 com o suporte da National Science Foundation (NSF).

Surgiu assim a rede NSFNet, com a implantação de seis grandes centros estrategicamente posicionados e munidos de supercomputadores, a partir do que redes estaduais e regionais foram sendo formadas, facilitando a qualquer instituição sua conexão. O objetivo dessa rede foi apoiar a pesquisa e a educação, proporcionando a comunidade de pesquisadores, educadores e estudantes uma comunicação rápida e eficaz, resultando mais tarde na conexão do meio acadêmico americano com seus congêneres em outros países (HENNING, 1993). com o crescimento da NSFNet, a ARPANET cede a esta o papel de espinha dorsal da rede Internet.

A Internet, maior rede de computadores do mundo, é frequentemente descrita como a rede das redes, pois abrange todas as espécies de redes possíveis, tornando-se verdadeira rede global, contando com mais de 13.170 redes regionais, nacionais e internacionais. Enquanto a BITNET é considerada uma rede WAN (Wide Área Network), alguns autores empregam o titulo de GAN (Global Área Network), para se referem à Internet.

Historicamente, o acesso \& Internet vinha sendo restrito a pessoas afiliadas a universidades ou instituições de pesquisas. Mas a pressão para se expandir o acesso aos indivíduos vinculados á educação superior, educadores e estudantes de $2^{\circ}$ grau cresceu tanto nos últimos anos que, por legislação específica, foi liberado o uso da NREN (National Research and Education Network). Do mesmo modo, o uso comercial, proibido naquele país até 1991, fica liberado, o que acentou ainda mais o crescimento da rede com entrada de milhões de novos usuários. Através da Internet atualmente tem-se nos EUA, durante 24 horas por dia, empresas vendendo produtos e serviços online, dando assistência aos consumidores, oferecendo catálogos e assinaturas de publicações, além de prestar outros

Os serviços básicos da Internet são:

\section{A) Correio Eletrônico (Email)}

Pode-se afirmar que as aplicações possíveis na BITNET são somente um pequeno conjunto, dentre as mais gerais aplicações disponíveis no ambiente Internet. Ela oferece um grau muito alto de interconectividade entre instituições e tem encorajado a criação de links (elos de ligação) entre outras redes para múltiplos fins. 
Note-se que pessoas podem se engajar em diferentes atividades através da rede: compartilhando informações primárias, debatendo padrões técnicos, desenvolvendo projetos de pesquisas em conjunto, buscando referências, revisando minutas de papers, editando jornais, planejando reuniões e viagens e muitas outras. Por baixo de todas essas múltiplas atividades, entretanto, está à atividade máxima, qual seja: a construção e manutenção de relações profissionais. Toda a capacidade e a velocidade da comunicação eletrônica estão perdidas se não forem usadas para se buscar, cultivar e nutrir o relacionamento entre pessoas e a troca de informações

Na Internet, portanto, além do correio eletrônico e todos os decorrentes dele já listados anteriormente (no item "Serviços básicos da BITNET"), têm-se ainda dois outros importantes serviços: a conexão remota (Telnet) e a transferência de arquivo (FTP-file transfer protocol).

\section{B) Conexão remota - TELNET}

Conectar-se remotamente significa dizer ligar-se interativamente a outros computadores da rede, via o protocolo específico denominado "Telnet". Ao fazer isso, o usuário passa a utilizar seu próprio computador como um terminal desse outro remotamente localizado e, assim, beneficia-se de forma interativa dos recursos nele disponíveis. E através desse serviço que se pode atualmente acessar, consultar e pesquisar mais de 500 bases de dados, centenas de catálogos de bibliotecas e os tão famosos OPACs (Online Public Access Catalogues), milhares de BBS e USENET ${ }^{7}$. Além de quantidades imensuráveis do arquivos técnicos, papers científicos, revistas eletrônicas, livros eletrônicos de texto na Integra, softwares, entre outros. Indispensável mencionar ainda a possibilidade de se utilizar software e mesmo computadores mais possantes e/ou supercomputadores localizados em outras instituições para "rodar" seus próprios programas remotamente.

\section{C) Transferência de arquivo - FTP}

A terceira capacidade da Internet possibilita ao usuário movimentar/transferir arquivos de um computador para outro. Esse serviço e diferenciado do descrito anteriormente na rede BITNET, porque aqui se utiliza o protocolo interativo denominado FTP (file transfer protocol). Esse protocolo possibilita aos usuários acesso eletrônico interativo a uma gama de informações armazenadas em repositórios de domínio publico distribuídos pelas redes, que fornecem arquivos gratuitamente. Dentre eles, tem-se

\footnotetext{
${ }^{7}$ A rede de notícias USENET é outra maneira de se participar em listas de discussão, em que a diferença básica e a forma de transmissão e leitura das mensagens. Trata-se de uma combinação das idéias de Grupos de Mala-Direta com a de services de Quadros de Aviso (Bulletin Board Services).
} 
informações demográficas, relatórios técnicos e científicos, softwares, receitas culinárias, textos completes de várias obras, artigos científicos, imagens, som, entre outros.

Um dos problemas atuais da Internet e a dificuldade em se localizar o que. se procura, exatamente por ser ela tão rica em informação e por dispor de tantos diferentes recursos. LYNCH (1992),observou, há poucos anos, que a rede assemelhava-se a uma biblioteca sem catálogos. Os catálogos, justamente agora, estão sendo inseridos em seus devidos lugares por meio de algumas ferramentas de apoio desenvolvidas especificamente como suporte a busca e a recuperac\&o de informação.

Exemplos dessas ferramentas são:

a) Archie: busca e recupera documentos distribuídos na rede, por intermédio de FTP anônimo. Na realidade, consulta uma grande base de dados com mais de 2.100.000 informações sobre repositórios de arquivos de domínio publico disponíveis via FTP ou no caso especifico de softwares, distribuídos pelo sistema shareware ${ }^{8}$.

b) Netfind: atua como o Archie, só que ao invés de localizar diretórios e arquivos de , localiza endereços eletrônicos de pessoas.

c) WAIS (Wide- Área Information Server): identifica bases de dados bibliográficas, factuais, econômicas e cadastrais disponíveis na Internet.

d) Gopher: possibilita ao usuário, através de menus, buscar e recuperar informações

Distribuídas por diversos computadores da rede. com ele, o usuário tem acesso tanto as informações armazenadas localmente, como aquelas armazenadas em qualquer outro computador da rede que aceite esse service (TILKIAN, 1994).

e) VERONICA (Very Easy Rodent-Oriented Net-wide Index to Computerized Archives)

: semelhante ao Archie, gera índice das informações disponíveis em todos os servidores Gophers cadastrados na Internet. A busca é feita por palavra-chave, ou lógica booleana.

f) WWW (World-Wide Web): variação do Gopher, é um sistema de exploração da Internet baseado no uso de hipertexto através de uma interface gráfica com o usuário. Por este sistema, arquivos, contendo documentos e imagens, são associados a outros arquivos através de palavras em destaque no texto. Uma vez selecionadas, estas

\footnotetext{
8 Shareware - método de comercialização de software pelo qual programas são livremente distribuídos, requerendo-se, porém o pagamento de uma taxa de registro ao autor em caso de adoção para uso em regime permanente.
} 
palavras, efetuam o acesso ao arquivo referenciado que pode residir no mesmo servidor ou em outros. Várias são as interfaces possíveis: o Lynx, o MOSAIC e mais recentemente o Netscape.

Por intermédio desses serviços listados acima, uma quantidade imensurável de informações se encontra disponível. Entre elas vale ressaltar a grande importância dos catálogos de bibliotecas e bases de dados os quais, acessíveis remotamente, tem possibilitado aos usuários acesso a dados antes impossíveis, ou demorados e com custos altíssimos.

Atualmente são centenas de bibliotecas publicam universitárias e especializadas, atuantes nas mais variadas áreas do conhecimento, que estão colocando disponíveis seus catálogos online. Já quanto às bases de dados, dois tipos são encontrados. Aquelas públicas, ou seja, de acesso gratuito (não significando com isso que estejam disponíveis a todo e qualquer usuário) e as comerciais, isto é, disponíveis mediante pagamento. Bases de dados como DIALOG, ORBIT, STN tão difundidas e utilizada no meio acadêmico, anteriormente acessíveis somente via RENPAC a um custo elevado, agora são fácil c agilmente acessadas e manuseadas via Internet (HENNING, 1994).

Além das informações sobre suas bibliotecas, algumas universidades também disponibilizam na Internet, serviços de informação sobre elas próprias. Utilizam para tanto, um sistema conhecido como "CWIS" (Campus Wide Informantion System), através do qual é possível localizar noticias e informações sobre o campus; diretórios de pessoal administrativo e técnico; programas e currículos dos cursos e disciplinas; produ9ão científica dos docentes; regulamentos, normas e horário de funcionamento das bibliotecas; e ainda dados referentes a atividades culturais, sociais e cotidianas de interesse do corpo discente e docente.

\subsubsection{As Redes Eletrônicas no Brasil $^{9}$}

No Brasil, Internet e assunto emergente, recebendo divulga9\&o constante nos mais variados eventos, na imprensa televisiva e escrita.

Numa síntese histórica, pode-se afirmar que desde 1987 pesquisadores brasileiros começam a se articular visando conectar-se as redes internacionais, o que acaba ocorrendo em 1988. A primeira conexão se deu em setembro entre o Laboratório Nacional de Computação Científica (LNCC), no Rio de Janeiro, RJ, e a University of

\footnotetext{
9 " Revisão preparada, com base no artigo publicado no FID News Bulletin, em novembro de 1994 (FERREIRA, 1994a).
} 
Maryland, USA (IBM para IBM com 9.600 bps). Logo em novembro, a Fundação de Amparo a Pesquisa de São Paulo (FAPESP) conecta-se ao Fermi National Laboratory /FERMILAB, em Chicago, IL (VAX a VAX; 4.800 bps). Em maio do ano seguinte, a Universidade Federal do Rio de Janeiro (UFRJ) estabelece ligação com a University of California at Los Angeles (UCLA) (IBM a IBM; 4.800 bps).

Essas conexões visaram, fundamentalmente, permitir a comunicação entre educadores e pesquisadores de universidades e centres de pesquisa no Brasil, com seus pares no exterior. As principais instituições brasileiras no gênero em vários Estados, rapidamente se ligaram ao LNCC ou a FAPESP, e o embrião da rede acadêmica brasileira principiou a tomar forma. Até 1990, praticamente todas as atividades eram puramente cooperativas, no sentido de que os enlaces eram custeados por uma ou talvez ambas as instituições interligadas. Os grandes custos eram das conexões internacionais, cobertos pelas três instituições que as operavam: LNCC, FAPESP e UFRJ (GETSCHO e STANTON, 1992).

Instala-se definitivamente no país ampla rede de tecnologia BITNET, com múltipla conectividade internacional, sendo sua topologia uma estrela dupla baseada na cidade de São Paulo, SP (FAPESP) e na cidade do Rio de Janeiro, RJ (LNCC).

No período citado, começa a ser discutida a possibilidade de se estruturar rede de âmbito nacional com aplicações as mais variadas, mas para tanto seria necessário adotar tecnologia de redes abertas, com topologia mais robusta, além de suporte técnico mais amplo do que o oferecido pela BITNET.

Em fevereiro de 1991, a FAPESP estabelece conexão a Internet, através de sub-canal da sua conexão internacional, ligando-se a ESNET (Energy Sciences Network). No mês de abril daquele mesmo ano, a conectividade foi estendida ao Rio de Janeiro através do LNCC e da PUC (Pontifícia Universidade Católica) e, ao Rio Grande do Sul, através da UFRGS (Universidade Federal do Rio Grande do Sul). Entretanto, sendo a capacidade das conexões muito reduzida, o uso foi apenas experimental.

Não obstante, em todos esses esforços era de importância fundamental o envolvimento dos governos federal e estaduais, por vários motivos. Assim, os dois grandes componentes do deslanchar dessa nova rede foram:

a) o estabelecimento de redes estaduais com recursos provenientes das Fundações de Amparo a Pesquisa (FAP), ou das Secretarias de C\&T de cada Estado, especialmente a ANSP (Academic Network of São Paulo), a Rede Rio no Rio de Janeiro, a RedeMinas, no Estado de Minas Gerais e a rede do Rio Grande do Sul);

b) a implementação, em 1990, da Rede Nacional de Pesquisa (RNP), como resultado final do Grupo de Trabalho do Ministério da Ciência e Tecnologia (MCT), que já vinha atuando desde 1988 com o objetivo especifico de propor "soluções urgentes 
para articular e integrar os esforços em redes acadêmicas no país, as quais tendiam a seguir em paralelo e independentemente" (TAKAHASHI, 1993).

A RNP, projeto coordenado pelo Conselho Nacional de Desenvolvimento Científico e Tecnológico (CNPq), tem como principal desafio inicial delimitar claramente abordagens cooperativas, de forma a assegurar a convergência das atividades já em andamento em nível nacional, bem como definir especificamente o papel dos esfor9os federais em redes no país. Ficou estabelecido desde o princípio que se dedicaria a articular as atividades de redes em nível nacional e internacional, cabendo a cada Estado ou região a responsabilidade pela disseminação de redes em seu âmbito político, e a cada instituição, a estruturação de seus próprios recursos de informática em rede interna, de forma que suas diversas unidades se intercomunicassem e compartilhassem de uma única porta de comunicação externa. Padronizou-se, assim, o modelo de atuação em redes no Brasil, inspirado na rede norteamericana, da National Science Foundation (NSFNet).

Apenas em maio de 1992, entretanto, véspera da Conferência Mundial sobre Ecologia e Desenvolvimento da ONU (ECO-92), são instaladas conexões internacionais de 64 kbps, inaugurando-se a nova rede brasileira com uso operacional da Internet, cujo acesso é feito entre FAPESP x FERMILAB, e UFRJ x CERFNct (San Diego, CA). Fica constituída, assim, a espinha dorsal da RNP, a qual hoje possui pontos de presença em todas as capitais do país, exceto nos Estados do Acre, Amapá, Piauí, Rondônia, Roraima e Sergipe. São centenas de instituições de ensino, pesquisa ou gestão governamental conectadas a RNP ou as redes estaduais.

Serviços básicos atualmente disponíveis incluem correio eletrônico; grupos de interesse em assuntos específicos (fóruns de debate); acesso a bases de dados nacionais e internacionais; catálogos de bibliotecas; serviços de informação; repositórios de pacotes de domínio público; acesso a máquinas remotas, ou login a distancia em computadores e supercomputadores, ligados em rede; transferência de arquivos, software, artigos, documentos, informações etc; e intercâmbio de mensagens em tempo real.

Com esses suportes, algumas das instituições brasileiras de ensino e pesquisa estão oferecendo serviços específicos de disseminação de suas informações administrativas, acadêmicas, sociais, culturais e outras, através de servidores Gopher e WWW, bem como informações de cunho bibliográfico, disponibilizando catálogos online de bibliotecas, bancos e bases de dados nacionais. O principal servidor Gopher no Brasil e o da RNP (gopher.rnp.br), o qual mantém links permanentes com todos os demais gophers brasileiros e vários internacionais. O WWW da RNP (http://www.rnp.br) oferece mapas, programas governamentais e informações diversas sobre a rede brasileira, sobre a própria instituição e mantém links com outros servidores nacionais e internacionais. 
Serviços do tipo News, USENET, Listas de Discussão e BBS tem sido os mais difundidos, abrangendo temas nas mais variadas áreas do conhecimento. Revistas e informativos eletrônicos vêm também merecendo atenção constante

Diretórios e guias brasileiros já estão sendo também acessíveis publicamente, em língua portuguesa, tanto impresso como eletronicamente.

Ao termino de 1993, portanto, a RNP concluiu a implantação de sua Fase I, a qual concentrou as atividades de implantação da mencionada espinha dorsal e de um conjunto de aplica96es em diversas áreas de especialização. Em sua Fase II, atual, que cobre o período de 1994-1995, espera lograr a efetiva consolidação da rede. Para tanto, várias metas foram tra9adas e diversos projetos se encontram em desenvolvimento.

Dentre essas metas, espera-se:

a) interligar algumas das capitais do país através de conexão dedicada de 2 MPs, assegurando conectividade a velocidades adequadas para responder a demanda concentrada em alguns grandes pólos regionais, especialmente Brasília, Rio de Janeiro e São Paulo;

b) permitir acesso a empresas e a organizações não governamentais, preservado o principio de uso para fins de educação e pesquisa sem caráter lucrativo;

c) monitorar mais apropriadamente o uso da espinha dorsal, com coleta de estatísticas de uso, ação preventiva/corretiva de opera96es e manutenção de equipamentos críticos;

d) implantar esquemas de capacitação avançada em redes, envolvendo treinamento, estágios, e projetos de prospec9ão tecnológica (BRASIL. MCT, 1994).

Referentes aos projetos em andamento, exemplos de destaque incluem:

a) "Televia da Educação": O Ministério da Educação/MEC e o de Comunicações (MINICOM) assinaram recentemente um convenio para implantação experimental de um projeto de educação à distância, utilizando as redes eletrônicas. Esse projeto, que envolve ainda a participação do Ministério de Ciência e Tecnologia (MCT) e do Ministério da Cultura, cria tarifa especial de serviços de comunica96es a vigorar para a iniciativa pelo prazo de 3 anos e tem como atividades previstas para 1995: experimento de introdução de redes no segundo grau; desenvolvimento/ adaptação de pacotes de software para uso em educação secundária; contratação de estudos sobre o uso de redes e tecnologias similares no ensino primário/secundário; montagem de repositórios de apoio a atividades relevantes para o tema (TAKAHASHI, 1994);

b) "Rede Antares": Coordenado pelo Instituto Brasileiro de informação Científica e Tecnológica (IBICT) do Conselho Nacional de Desenvolvimento Científico e Tecnológico (CNPq), esse projeto objetiva organizar a oferta e estimular a demanda por informação em Ciência e tecnologia, criando infra-estrutura tecnológica, de serviços e de recursos humanos. Trata-se de 65 postos serviços a serem 
instalados em instituições brasileiras e estrategicamente distribuídas por todo o território nacional, colocando a disposição das comunidades científica, tecnológica e empresarial as principais bases de dados nacionais e internacionais em Ciência e tecnologia. com base em telemática e estrutura descentralizada, prioriza a ampliação da oferta de serviços de informação nacional e o uso da RNP como infra-estrutura para o oferecimento desses serviços (KURAMOTO, 1994, p.4).

Dados estatísticos apresentados pela FAPESP, mostram que, em julho de 1991, o país tinha 111 computadores hosts conectados a Internet; no ano seguinte, 943; e 1101 em 1993. Em julho de 1994, existiam já 5896 hosts brasileiros. Em geral, estimasse um número entre 10 e 20 usuários por maquina, o que faria com que a Internet no lado brasileiro tivesse algo em torno de 50 a 100 mil usuários naquela data.

No ranking da América Latina, o Brasil tem-se revezado com o México na Liderança desde 1991. Em outubro de 1994, o Brasil estava em $2^{\circ}$ lugar com 7010 máquinas e o México com 7641. Isto mostra o desenvolvimento exponencial por que vem passando a rede nacional.

A Internet comercial brasileira foi lançada oficialmente no dia 27 de outubro, pela EMBRATEL, e será implantada com o envolvimento direto da RNP.

Espera-se que até abril de 1995 vá funcionar em caráter experimental com cerca de 40 empresas estabelecidas no triângulo São Paulo, Brasília e Rio de Janeiro. O acesso oferecido será tanto discado via RENPAC, como direto através de um banco de modems.

Resultante de uma parceria com a RNP, a rede comercial sai de uma conexão da acadêmica. Portanto, as duas vão se cruzar fisicamente embora atuem independentemente.

\subsubsection{A Experiência da Universidade de São Paulo}

Atividades de computação na USP se iniciaram na Escola Politécnica, em 1961, com a aquisição e instalação do primeiro computador IBM1620, surgindo à semente do atual Centro de Computação Eletrônico (CCE). Centro esse que passou para o Instituto de Matemática em 1963, tornando-se um órgão com vinculação direta a Reitoria, mas sem estrutura independente de 1971 a 1987.

A partir de Janeiro de 1988, o CCE torna-se uma Coordenadoria, cuja finalidade e a prestação de serviços a todos os órgãos da Universidade. Isso compreende o processamento das atividades de computação eletrônica para atividades didáticas e administrativas, a divulgação do uso de equipamentos e serviços relacionados à 
Informática e a prestação de consultoria e treinamento de docentes e pesquisadores (MORGADO, 1991, p.75).

A utilização de processamento de dados em alta escala teve inicio ao final da década de 80 , com a instalação da reed ASTIR, para fins primordialmente administrativos. Consistia, na época, de 1200 terminais alfa-numéricos ligados a um computador central de grande porte, através de pares telefônicos.

Esta rede alcança hoje todos os pontos da Universidade e é usada para a realização de suas tarefas administrativas, tais como controle de processos, sistemas de matrículas, administração de pessoal, administração financeira e também comporta o banco de dados DEDALUS - Sistema Integrado das Bibliotecas da USP.

A crescente utilização de micro-computadores pelas várias unidades da USP e a necessidade de proporcionar uma utilização plena dos recursos computacionais da universidade for9aram a implementação, em 1987, do projeto de rede local, intitulado REDEUSP. Por esta ocasião, o CCE interliga seus 4 computadores de grande porte (CDE Cyber 170/730, Unisys B7900, Unisys A-15 e IBM 4381), com previsão de Ligações urgentes com os computadores do Instituto de Física (IFUSP), Instituto Agronômico e Geofísico (IAG) e Escola de Engenharia de São Carlos (EESC).

Instala-se assim a primeira rede acadêmica na USP, contando com conexões por meio de linhas seriais síncronas através de protocolo X-25 e software desenvolvido pelo próprio CCE (USP. CCE, 1992, p. 18), possibilitando acesso ao DEDALUS e ao Serviço de Consultoria do CCE.

Por esta ocasião, têm-se a iniciativa pioneira da FAPESP de conectar-se a BITNET, facilitando sua participação as universidades paulistas. Assim é que, em março de 1989, a BITNET começa a ser implementada, funcionando em caráter experimental até julho. A ligação da USP com a FAPESP era feita através de três linhas dedicadas, interligando o VAX da FAPESP com o IBM 4381 da USP. A comunicação era feita pelo RSCS, que sob o sistema operacional VM, dava suporte aquela rede (MORGADO, 1991, p.78).

Um levantamento das necessidades de estações de trabalho e microcomputadores, desenvolvido junto às unidades de ensino e pesquisa da USP, no ano de 1990, evidenciou a premência de se favorecer o processamento distribuído, formando redes de comunicação onde os usuários dispusessem de meios para se comunicar com outros equipamentos e utilizar seus recursos.

A REDUSP, muito embora fosse tècnicamente complexa, possuía horizontes muito limitados pela própria arquitetura disponível na época. Porém, com base nessa experiência, foi projetada a atual rede USPnet, cuja implantação teve início em 1991. Também foi resultado da primeira rede a definição da atual política de informática 
vigente na USP, baseada em sistemas abertos e, em arquiteturas heterogêneas, totalmente integradas através de uma rede computacional (USP. CCI, 1994, p. 14).

Com a USPnet, várias LAN, padrão Ethernet, instaladas nas unidades, interligaram-se ao CCE através de linha serial assíncrona utilizando protocolo SLIP por meio de microcomputadores emulando roteadores (USP. CCE, 1992, p. 18).

A partir de 1991, quando o UNIX e a Internet se tornam disponível na USP, iniciam substanciais mudan9as nas decisões estratégicas e nos hábitos computacionais da comunidade uspiana.

Na fase inicial de implantação da USPnet, ficou acordado que o CCE controlaria sua administração geral, fornecendo o backbone da rede e providenciando o cabeamento de conexões ate cada uma das unidades. Essas se ligariam, através de um único ponto, a rede do campus onde estivesse localizada. Internamente, a expansão desse ponto ficaria a cargo das unidades.

Esse processo de instalação prosseguiu ativamente, nos anos de 92 e 93, mesmo assim não se encontra em estagio ideal. Objetivando promover a integração dos sistemas computacionais de seus sete campi, já contava em ago/94 com a interconexão de 10.000 processadores, apresentando estrutura geral tipo WAN de grande porte, incluindo redes locais de cada edifício, rede dos campi, rede intercampi, e as ligações externas com outras redes. Reveste-se, portanto, de grande complexidade e extensão, sendo provavelmente uma das maiores, mais versáteis e heteróxenas dentre as rede acadêmica do país.

Sua crescente evolução e atualização têm sido consideradas assunto de primeira ordem na área de informática, sendo motive de estudos profundos para desenvolvimento de projeto de conclusão, pelo Grupo de Assessoramento Técnico em Informática (GATI) e pelo CCE, a pedido da Comissão Central de Informática (CCI) da USP. Com base nesse projeto, segue uma síntese da situação atual da USP (USP. CCI 1994).

Muito embora suas instalações ainda não estejam completas, a USPnet encontra-se em estágio operacional. Dentre suas características, percebe-se grande varia9\&o na situação das redes locais dos diversos Institutos. Enquanto alguns se encontram precariamente conectados, outros mostram estágios bastante avançados. O Instituto de Física, o Instituto de Química e o Instituto de Matemática representam, nessa ordem, as três unidades melhor equipadas da USP, sendo, porém, bem diferenciadas entre si.

Quanto às redes dos campi, praticamente todos os ramais de fibra ótica previstos inicialmente foram instalados, totalizando cerca de $70 \mathrm{~km}$ de cabos. Porém, 
ainda falta muito dos equipamentos de interconexão físicas necessárias a operação adequada dos ramais.

Todos os campi e unidades isoladas da USP, já se encontram ligados a rede, embora alguns de forma bastante precária. O acesso externo e possível através da RENPAC ou por modems via linha discada. Uma linha telefônica dedicada de 64 kpbs, ligando o CCE a FAPESP, e a principal ligação externa da USPnet. Outras conexões diretas, menores, existem com a Universidade Federal do Paraná (BITNET), a Universidade Federal de Minas Gerais (UFMG), a Universidade Federal da Paraíba (UFPb) e ao Instituto de Pesquisas Energéticas e Nucleares (IPEN).

Várias são as propostas de completação e desenvolvimento apresentado pelo citado Grupo, visando maior integridade interna e externa e o aumento da produtividade da USP como um todo, através da implementação de uma rede computacional completa.

Tem crescido consideravelmente a utilização dessas redes no ambiente acadêmico, o que nos leva a considerar suas inúmeras vantagens para a comunidade científica.

\subsection{A COMUNIDADE CIENTÍFICA FACE ÃO ACESSO Á INFORMAÇÃO VIA REDES ELETRÔNICAS}

Segundo LYNCH (1993, p.6), a tecnologia da informação, os computadores e as redes eletrônicas, estão mudando muitas das suposições, anteriormente existentes, sobre como as pessoas aprendem, ensinam, acessam e usam informação. Novos métodos para produzir, organizar, estocar, acessar, recuperar e disseminar informação em formato digital estão aparecendo. E esta informação se torna parte critica no fluxo da comunicação científica e dos registros históricos e culturais de nossa sociedade (LYNCH, 1994, p.737).

Segundo GARVEY (1979), "comunicação científica inclui o espectro total de atividades associadas com a produção, disseminação e uso de informação desde o instante em que o cientista concebe a idéia para sua pesquisa até quando as informações de seu trabalho são aceitas como constituintes do conhecimento científico". Menciona

ainda que "significa aquela atividade de troca de informação que ocorre entre cientistas ativamente envolvidos em frentes de pesquisas. Compreendendo desde a discussão informal entre dois cientistas ate" a apresentação formal dos resultados de pesquisa em peri6dicos, livros, reviews, e outros". 
Esse mesmo autor, juntamente com um grupo de pesquisadores, em 1979, examinando diferenças individuais entre 2030 cientistas, descobriu que tanto o comportamento em si do cientista como as necessidades de informação e o uso das diferentes mídias mudam em consonância com o progresso do cientista, de estágio em estagio, no decorrer de sua produção científica. Verificou, ainda, que tais necessidades e comportamentos variam entre os cientistas, de acordo com certos fatores, tais como:

a) área de atuação do cientista (Ciências sociais versus Ciências exatas);

b) tipo de pesquisa em desenvolvimento (básica versus aplicada);

c) grau de evolução do cientista (experientes versus inexperientes);

d) área de especialidade (cientistas trabalhando em áreas clássicas de assunto versus cientistas trabalhando em áreas de temas emergentes), entre outros (GARVEY e AL, 1979).

Todos esses resultados provocam significantes variações nas necessidades de informações dos cientistas e nas fontes que eles usam para satisfazer suas linhas de interesse.

Sabe-se atualmente que o sistema global de informação científica e tecnológica utiliza fundamentalmente dois canais básicos de comunicação: os canais formais10 e os informais11, tendo ambas as importância equivalente no contexto geral. Porém, devido ao volume assustadoramente crescente que vinha ocorrendo nas publicações técnico-científicas, dobrando de produção a cada 10-15 anos (PRICE, 1976), os canais informais de comunicação foram relegados a um segundo piano. Pesquisas mais recentes ainda comprovam tal situação.

Estudos considerando o papel dos canais informais de comunicação técnica, no que diz respeito à inovação, indicam, por exemplo, que os canais informais contribuíram com 7590\% das idéias básicas das inovações tecnológicas (COONEY; ALLEN, 1974). Jci PRICE (1976) menciona que os "colégios invisíveis"12, mediante um mecanismo de feedback , além de aumentar a produtividade de papers e de autores prolíferos, atuam também sobre as atividades sociais e políticas. terciários

${ }^{10}$ Também conhecidos como canais de literatura, referem-se aos documentos primários, secundários e

${ }^{11}$ Os canais informais, também conhecidos como interpessoais, envolvem basicamente a comunicação oral (conversas, telefonemas, discursos, conferências, discussões, técnicas científicas) e também a comunicação escrita (cartas, pre-impressos). As principais fontes de comunicação informal são as pessoas, permitindo a interação direta entre a fonte e o usuário. (CEPEDA).

12 "Colégios invisíveis" são grupos de indivíduos com frequência muito distanciados geograficamente, com um interesse especifico comum, que trocam correspondência e noticias sobre novas publica95es e citamse mutuamente. Constiruem-se numa congregação flexível, mas da qual não e fácil fazer parte, enquanto que o castigo por permanecer fora e não estar ao corrente da ultimas novidades do assunto (LINE, MJ. 1978. P.28). 
Uma das diferenças fundamentais entre esse tipo de comunicação e a formal e a velocidade de divulgação da informação, tendo em vista que, muito antes de ser publicado em uma revista, um artigo já foi "anunciado" e discutido com parte do público a que se destina.

Os canais informais permitem ao cientista a obtenção de retroalimentação crítica pessoal e de esforço muito mais rápido, permitindo assim o esclarecimento imediato de dúvidas a respeito de aspectos de seu comportamento científico, ou de seu trabalho.

É desnecessário dizer, diante desse contexto, quão grande e profundo tem sido o impacto da revolução eletrônica na comunicação científica. Pesquisadores de todas as partes do mundo descobrem que seus trabalhos florescem cada vez mais em ambientes de rede. Acesso imediato ao trabalho de colegas ou a uma imensidade de produção científica, através das redes eletrônicas, tem habilitado esses profissionais a manusear e incorporar intenso volume de conhecimento interdisciplinar. Grupos de Trabalho podem agora realizar conferência interativas, sem se preocupar com a localização geográfica dos participantes (KEHOE, 1992).

Um novo leque de possibilidades de acesso se encontra em disponibilidade caracterizando a atual "sociedade da informação". A quantidade de informação produzida diariamente e imensurável; a variedade e diversidade de formatos e de suportes de informação aumenta constantemente; e as formas de acesso a todo e qualquer tipo de informação, por meio das atuais redes internacionais de comunicação, como INTERNET e BITNET, por exemplo, derrubam fronteiras geográficas e ampliam horizontes muito rapidamente.

Também a comunicação interpessoal ganha nova dimensão. O acesso fácil a profissionais e/ou especialistas nos mais variados ramos, bem como as trocas de experiências de modo rápido, ágil, informal, democrático e desvinculado de padrões hierárquicos (via correio, grupos de discussões e quadros de avisos eletrônicos) tem revalorizado a busca de informação diretamente junto a "especialistas".

Instituições de toda espécie tornam-se acessíveis através de conexão remota, passando de fontes de informação potenciais para reais. Facilitam-se o acesso e divulgação de variado tipo de informação seja técnico-científica e/ou bibliográfica, comunitária e/ou comercial; empresarial e/ou universitária, social e/ou cultural.

Amplia-se, também, a possibilidade de acesso a arquivos completos em seu local de origem, via FTP (protocolo de transferência de arquivo). Como por exemplo a produção técnica interna de centenas de instituições, do tipo relatórios de projetos, resultados de pesquisas, material publicado em congresso, teses, softwares e aplicativos 
de acesso público, normas, publicações oficiais e mesmo informações em formatos não textuais como gravuras, mapas, e até sons musicais.

Com certeza, esta agora instituído um novo canal de acesso a materiais nãoconvencionais, também intitulados "literatura cinzenta, fugitiva, invisível, informal e mesmo efêmera ${ }^{13}$ exatamente pela anterior dificuldade de coleta, armazenamento e recuperação.

Por outro lado, ainda em decorrência do advento das redes eletrônicas, a própria literatura impressa, que integra os canais formais, está passando por reestruturações, tendo em vista a já existência de publicações inteiramente acessíveis via online, incluindo aqui periódicos diversos, livros técnicos e profissionalizantes, literatura geral, e ainda obras de referenda como dicionários, enciclopédias, thesauros, guias, diretórios, entre outros. Inúmeros serviços de recuperação da informação (bibliográficos, não-bibliográficos, estatísticos etc.) e, bases de dados multimídia (com textos integrados a fotos, sons, imagens, etc.) se encontram disponíveis via Internet.

Tudo isso se concentra na chamada "biblioteca virtual ${ }^{14}$, que prepara os caminhos para o futuro centro virtual de informação em que o acesso a informação, no que concerne a sua natureza, conteúdo e formato, será praticamente ilimitado e se fará totalmente por meios eletrônicos, com redes cada vez mais versáteis, velozes e capazes" (VIEIRA, 1994).

Quanto aos benefícios advindos do uso das RE, DOTY (1992, p. 185) afirma que "o acesso crescente a várias ferramentas, recursos de informação e pessoas naturalmente são consideráveis. As "ferramentas" podem facilitar o acesso a equipamentos remotos, por exemplo, a um acelerador de partículas, um telescópio, um supercomputador, ou softwares para análises estatísticas de dados, entre outros. Pessoas acessíveis online podem incluir colaboradores potenciais e reais, amigos, colegas, pares, especialistas em várias áreas, indivíduos ou grupos em geral. Acima de tudo o mais importante e que o uso das redes eletrônicas pelos cientistas aumentam os registros científicos disponíveis. Isto e dados, documentos, pessoas, ferramentas nos vários estágios de sua produção.

Outros benefícios importantes de uso das RE pela comunidade científica, ainda segundo DOTY (1992) e BROPHY (1993), são:

\footnotetext{
${ }^{13}$ Literatura cinzenta" são documentos que se caracterizam segundo sua apresentação não convencional, portanto, não sendo publicada e distribuída através dos canais normais do parque editorial. Inclue: relatórios de todos os tipos (internos, institucionais, técnicos, de pesquisa, de comiss5es e outros), as comunica9oes apresentadas em eventos, o anais e atas de reuniões, as conferência, pre-prints, publicações oficiais, teses, traduções, patentes, normas e outros (POBLACION, 1992, p.243).

${ }^{14}$ Segundo DRABENSTOTT (1994, p.9), várias termos estão sendo utilizados para denominar a biblioteca do "futuro", tais como: biblioteca virtual, eletrônica, digital, sem paredes e/ou biônica.
} 
a) assincronia: a comunicação, por correio eletrônico por exemplo, não exige a presença simultânea do emissor e receptor. Tal processo transcende o espaço (como o telefone) e o tempo. TUROFF e HILTZ (1988) completam que a natureza asincronica da comunicação mediada pelo computador tende a levar os indivíduos a maiores reflexões antes de responder a terceiros, do que outros meios de comunicação;

b) interatividade: possibilita intercomunicação em tempo real com outras máquinas (especificamente na Internet);

c) transparência multi-sistema: facilita a navegação entre vários sistemas através de estruturas de "menus" (hierárquicos e hipertexto). O usuário acessa, muitas vezes sem se dar conta, bases de dados instaladas no computador de sua instituição de origem, ou em outra instituição nacional ou internacional;

d) aproximação geográfica: propicia e facilita o desenvolvimento de atividades de colaboração entre indivíduos distantes geograficamente;

e) relações inter-grupos: favorece a manutenção das relações provindas tanto das atividades profissionais como sociais entre os indivíduos;

f) conveniência pessoal: as informações são procuradas conforme conveniência do usuário, entregues direta e imediatamente, no formato mais apropriado as suas necessidades.

O fato de a Internet oferecer acesso a uma quantidade imensurável de informação e o custo direto deste acesso não ser repassado aos usuários foram considerados por LYNCH e PRESTON (1990, p.268) fatores bastante motivadores para o uso das RE.

Já quanto às barreiras e dificuldades, de maneira geral, parece ser possível demarcar em grandes blocos os problemas existentes para a busca e uso de informação em redes eletrônicas. Adaptando a classificação que RAITT (apud CLAUSEN, 1992) utiliza para descrever barreiras no processo de comunicação, tem-se:

a) problemas pessoais: desconhecimento e/ou dificuldades dos usuários quanto ao mais adequado uso dos diferentes comandos, aplicações e dispositivos da rede. Falta de formação e treinamento para se "navegar" mais eficientemente nas RE. Fatores individuais como julgamentos, emoções, valores, gostos, entre outros, também estão aqui incluídos.

b) problemas físicos: fatores ambientais, localização física, diferenças horárias, barreiras legais e políticas, disponibilidade de equipamentos;

c) problemas tecnológicos: velocidade de desenvolvimento de novos produtos, aplicativos, serviços e recursos tecnológicos, tipos de equipamentos e plataformas utilizadas, formas de conexão, falta de padronização; 
d) problemas lingüísticos: usos particulares de cada língua, compreensão dos idiomas nacionais e estrangeiros, complexidade da informação.

e) problemas econômicos: custo dos equipamentos de hardware e software, cabeamento, instalação, entre outros.

f) problemas informacionais: talvez o mais difícil de ser contornado, refere-se às dificuldades crescentes para se identificar, selecionar, acessar, utilizar e recuperar informações relevantes dentre o grande número de possibilidades existentes; as múltiplas formas de acesso e interfaces existentes. GAUCH (apud MARCHIONINI, 1992) menciona que o problema de recuperação de informação no ambiente eletrônico não e somente encontrar a informação, mas filtrá-la.

Acresce-se aqui, o fato de que instituições no mundo todo estão quase diariamente colocando novas informações disponíveis via rede, porém de forma aleatória, sem seguir padrões claros e pré-estabelecidos de ordenação lógica e racional das mesmas. Muito embora existam vários aplicativos já desenvolvidos, e em desenvolvimento, visando ordenar e organizar blocos específicos de informações na rede falta, ainda assim, mais profunda conscientização por parte dos envolvidos. Esta situação bastante complexa resulta das características principais das redes: não terem limites geográficos, serem universais e ecléticas. Estes fatos se agravam frente ao seu ininterrupto aperfeiçoamento tecnológico, a dinâmica de desenvolvimento e crescimento que vem recebendo. Deve-se relembrar que a atual abertura da rede Internet para uso comercial em todo o mundo, inclusive o Brasil, trará maiores implicações.

Sintetizando, parece ser bastante evidente que a comunicação eletrônica pode exercer influência no comportamento dos pesquisadores, aguçando as necessidades de informação da comunidade científica e acadêmica.

A importância das RE no ambiente acadêmico foi muito bem apreendida pelo Grupo de Assessoramento Técnico em Informática da USP, em sua explicação dos objetivos da USPnet:

Projeta-se que o uso da rede computacional conduza a USP, como um todo, a um aumento substancial tanto da quantidade quanto da qualidade das suas atividades de ensino, pesquisa e extensão. Esta expectativa e baseada no extraordinário poder integrador e multiplicador da nascente cultura computacional, que permite um volume de comunicações, praticamente com o mundo inteiro, simplesmente inimaginável poucos anos atrás.

Este fato permitira, a médio prazo, a integração das diversas comunidades da Universidade não apenas entre si, mas também com as suas congêneres em outros centres no pai's e no exterior. A correspondente aglutinação resultara numa Universidade mais ativa, mais ágil e mais produtiva, criando com o tempo, amplas condi9des para que ela se integre aos centres mais desenvolvidos do mundo (USP. CCI, 1994). 
Foi nesse contexto, após cinco anos de convivência, cada vez mais ampla de algumas comunidades da USP com o mundo exterior, que se sentiu a necessidade de estudos específicos que analisassem o resultado dessa vivência. A compreensão de como se organiza, altera e ajusta o processo de busca e uso da informação de usuários em ambiente acadêmico, frente as novas possibilidades de acesso oferecidas pelas atuais redes eletrônicas, motivou este estudo. 


\section{Capítulo 3}

\section{NECESSIDADES DE INFORMAÇÃO}

Das abordagens tradicionais ao novo enfoque metodológico

Estudos de necessidades de informação, abordagens tradicionais e alternativas. O Sense-Making Approach desenvolvido por Brenda Dervin. Termos adotados na pesquisa. 


\section{PRELIMINARES}

Foi a partir do trabalho de BERNAL e URQUHART, apresentado na Conferência de Informação Científica da Royal Society em 1948, que surgiram as primeiras reflexões sobre estudos orientados as necessidades de usuários, mais especificamente focalizando a maneira como os cientistas e técnicos procedem para obter informação, ou como usam a literatura nas suas respectivas áreas (FIGUEIREDO, 1979, 1983).

Estudos dessa natureza passaram por várias e diferentes fases:

- Inicialmente, final da década de 40, tinham como objetivo agilizar e aperfeiçoar serviços e produtos prestados pelas bibliotecas. Tais estudos restringiam-se a área de ciências exatas.

- Na década de 50, intensificaram-se os estudos sobre o uso da informação entre grupos específicos de usuários, abrangendo já as Ciências aplicadas.

- Só nos anos 60 e que se enfatiza o comportamento do usuários; surgindo estudos de fluxo da informação, canais formais e informais. Os tecnólogos e educadores começam a ser pesquisados.

- Já. na década de 70, a preocupação maior passa a ser o usuário e a satisfação de suas necessidades de informação, atendendo a outras áreas do conhecimento como humanidades, Ciências socias e administrativas.

- A partir de 80, os estudos estão voltados à avaliação de satisfação e desempenho.

Desde 1960, vem crescendo na literatura internacional estudos que ilustram e analisam muitos e diferentes aspectos de busca e uso da informação, fato esse acentuado com o ínscio (em 1966) da serão especial sobre "Necessidades e Usos de Informação" na publicação Annual Review of Information Science and Technology I ARIST.

Das várias revisões sobre o estado-da-arte na área, algumas considerações gerais podem ser delineadas:

a) Até a década de 70, estudos se configuravam em dois tipos: orientados ao uso de uma biblioteca/serviço; ou orientados ao usuário, i.e., como grupos particulares de usuários obtinham a informação necessária ao desempenho de suas atividades profissionais (WILSON e DAVIS apud CUNHA, 1982).

b) diversos estudos têm sido direcionados para o comportamento de busca e uso da informação em população específica como cientistas, físicos, químicos, engenheiros etc. Também usuários de bibliotecas públicas, universitárias, especializadas oriundos de vários parses - vêm sendo pesquisados (LINE, 1971; MARTYN, 1974;

\footnotetext{
${ }^{1}$ São da década de 70 os primeiros trabalhos na literatura especializada brasileira sobre o tema.
} 
FAIBISOFF e ELY, 1976; ZWEIZIG e DERVIN, 1977, STONE, 1982; STONE, (1982; RHODE, 1986).

c) DS principais objetivos desses estudos tinham o fito de:

- determinar os documentos mais utilizados,

- descobrir hábitos dos usuários para obter informação nas fontes disponíveis, bem como as maneiras de busca (uso de serviços de recuperação de informação, processo de citação, canais informais, etc.)

- estudar aceitação das inovações tecnológicas da época;

- evidenciar o uso feito dos documentos;

- pesquisar as maneiras para obtenção de acesso aos documentos;

- determinar as demoras toleráveis. (FIGUEIREDO, 1979, 1994).

d) os resultados obtidos, bastante diversificados, serão comentados no decorrer deste capítulo. Parte deles possibilitaram generalizar dados, os quais tem sido utilizados para direcionar e auxiliar administradores na melhoria de seus sistemas de informação.

WILSON (1981) assegura que estudos desenvolvidos ate a década de 70 compreendiam necessidades de informação de forma tal que levam os sistemas de informação cada vez mais a se marginalizarem no que tange ao atendimento das reais necessidades dos usuários. STONE(1982) também critica esses estudos, por oferecerem mínimas diretrizes sobre a forma como os sistemas estão encontrando as necessidades de seus usuários. Afirma que a literatura propicia pouco apoio aos profissionais da informação sobre como descobrir as necessidades de usuários, sendo provável que mais confundam do que elucidem.

WHITE (apud DERVIN e NILAN, 1986) conclui que tais estudos têm reiterado somente aquilo que os sistemas de informação têm colocado nas mentes dos usuários e, consequentemente, não tem ajudado a manejar efetivamente problemas reais.

MARTYN (apud FIGUEIREDO, 1994, p.28) sintetiza dizendo que "inicialmente, os estudos de usuários dirigiram-se para o uso das bibliotecas: quem, o que, quando, onde. Apenas um pequeno grupo de estudos tentou saber como as bibliotecas são utilizadas, uns poucos procuraram interpretar o porquê usuários as utilizam e quais os efeitos do uso da biblioteca na vida, estudo, trabalho dos usuários."

Enquanto as descrições acima são resultados e/ou conclusões específicas de estudos individuais, algumas revisões do estado-da-arte tem mostrado um panorama muito mais amplo, que tem contribuído de modo eficaz para a implementação de sistemas e serviços de informação.

Nas revisões publicadas pelo ARIST, os problemas críticos e generalizáveis quanto aos estudos de necessidade e uso da informação podem ser considerados como: (a) falta de uniformidade conceitual nas pesquisas; termos como 
informação, necessidades de informação e uso da informação tem sido utilizados indiscriminadamente; (b) faltam defini96es e pressupostos claros para focalizar variáveis e gerar questões de pesquisa e (c) ausência de metodologias específicas, abrangentes e com rigor científico (DERVIN, NILAN, 1986). A inadequabilidade das metodologias adotadas tem sido apontada unanimemente por vários revisores (MENZEL, 1966; HERNER e HERNER, 1967; PAÍSLEY, 1968; LIN e GARVEY, 1972; DERVIN e NILAN, 1986).

Outros revisores indicam ainda que por várias décadas estudos descrevem as ações dos usuários e expressam suas necessidades a partir da perspectiva do sistema de informação e dos provedores de informação (FORD, 1973; FAIBISOFF e ELY, 1976; ZWEIZIG e DERVIN, 1977; MICK e LINDSEY e CALLAHAN, 1980; DERVIN e NILAN e JACOBSON, 1981; DERVIN e JACOBSON e NILAN, 1982; JAMES, 1983; KRIKELAS, 1983; BELKIN, 1984; ROUSE e ROUSE, 1984; RHODE, 1986; TAYLOR, 1986; WILSON, 1981, 1984).

\subsection{DIFERENTES ABORDAGENS PARA ESTUDO DE NECESSIDADES}

Decorrente desse contexto, ao final de 1970, surge nova cconcepção para estudos de comportamento de busca e uso da informação. Segundo DERVIN e NILAN (1986), a partir dá a literatura tem divergido em duas direções:

a) abordagem tradicional, estudos direcionados sob a ótica do sistema de informação ou biblioteca (system-oriented approach ou traditional approach);

b) abordagem alternativa, isto d, direcionada sob a ótica do usuário (user-oriented approach ou alternative approach).

\subsubsection{Abordagens Tradicionais}

Segundo TAYLOR (1986), os estudos dentro desse paradigma tradicional tem sido dirigidos ao "conteúdo" ou a "tecnologia".

São voltados ao conteúdo os estudos relacionados às linhas temáticas de interesse de grupos de usuários, sempre baseados nos modelos tradicionais de classificação do conhecimento, utilizando por exemplo as classifica96es decimais existentes. Embora, na maioria das vezes, esses modelos sejam desconhecidos pelos usuários, continuam a servir de denominadores para determinar a estrutura organizacional da informação no bojo do sistema. 
Já estudos enfocando o uso de livros, fontes, bases de dados, obras de referenda, computador ou o próprio sistema são voltados a "tecnologia". A ênfase esta na maneira com que isto afeta o armazenamento, acessibilidade e a disseminação da informação ou do conhecimento. Baseado em seus resultados, esses estudos tem prescrito tamanhos, formatos, dinâmica e mesmo os tipos de materiais a serem incorporados aos sistemas de informação.

Nesses dois mencionados tipos de estudos, o usuário e apenas o informante. Não sendo em nenhum momento o objeto do estudo.

De acordo com DERVIN e NILAN (1986), estudos voltados para a abordagem tradicional, geralmente examinam o comportamento do usuário real ou potencial nas seguintes atitudes:

1) usa um ou mais sistemas de informação, um ou mais tipos de serviços de informação e materiais;

2) c afetado por uma ou mais barreiras ao uso do sistema de informação; e

3) demonstra satisfação com os vários atributos do sistema.

Nessa abordagem, a informação e considerada pois como algo objetivo, existente fora das pessoas e passível de ser transferida de uma para outra. Segundo DERVIN e NILAN (1986), várias tem sido suas definições: e uma propriedade da matéria; ou qualquer mensagem, documento ou fonte; qualquer material simbólico disponível para o publico; qualquer dado. Portanto, parece ser possível que eficiência e sucesso das opera9oes de um sistema possam ser medidos em fun9\&o do número de fontes de informações recuperadas pelo sistema versus o que realmente foi de interesse do usuário. Isso coloca o usuário como um processador imperfeito da informação, pois e já sabido que nem todas as pessoas se interessam pelas mesmas fontes indicadas.

Conforme citado por RHODE (1986), ignora-se o fato de que o ser humano cria sua própria realidade, e tem seus próprios estoques internos de informação, os quais são usados para compreender as informa9des externas e as diferentes situações em que os indivíduos se encontram em dado momento.

Ao contrário, procura-se, nesses estudos, explicar as diferenças entre os usuários como simples decorrência de influências sociológicas e demográficas, estilo de vida e especificidade do trabalho (DERVIN e NILAN, 1986). Entretanto, comportamento de busca e uso de informação são também modelados pelo estilo cognitivo do indivíduo, i.e., sujeito ativo internamente versus ativo externamente, sistemático versus intuitivo, e/ou criativo versus menos criativo (ROUSE e ROUSE, 1984), sendo esse o veio da abordagem alternativa.

A abordagem tradicional não tem examinado os fatores que geram o encontro do usuário com os sistemas de informação ou as conseqüências de tal confronto. 
Limita-se a tarefa de localizar fontes e informação, desconsiderando as tarefas de interpretação, formulação e aprendizagem envolvidas no processo de busca de informação. O aumento no acesso a vasta quantidade de informação requer serviços que se centrem no significado da busca mais do que meramente na localização da fonte.

Segundo MICK, LINDSEY e CALLAHAN (1980) "a transição efetiva para a era da informação exige mudança daqueles sistemas de informação respaldados nos critérios de tecnologia e conteúdo para sistemas dirigidos pelas necessidades dos usuários". Ademais, WILSON (1981) sugere que deveria ocorrer uma mudança nas orientações metodológicas dos estudos encaixando-os nos estudos de "percepção dos usuários", visando reduzir a marginalidade dos sistemas de informação atuais.

A abordagem tradicional não vem se mostrando adequada para acomodar os diferentes tipos de problemas dos usuários na era da informação. Portanto, grande parte das pesquisas atuais vem buscando auxilio e respaldo metodológico junto às abordagens alternativas.

Diversos exemplos de estudos, delineados dentro desta abordagem tradicional, foram e ainda estão sendo desenvolvidos em diferentes países, tornando a literatura bastante volumosa. Pode-se arriscar a afirmar que referente ao Brasil, grande parte dos estudos de usuários desenvolvidos ate a presente data tem sido delineados na antiga abordagem.

\subsubsection{Novas Abordagens de Estudos de Necessidades; ou Abordagens Alternativas}

Conhecidos também como "abordagem centrada no usuário", ou ainda "abordagem da percepção do usuário", estes novos estudos de comportamento de usuários se caracterizam por:

1) observar o ser humano como sendo construtivo e ativo;

2) considerar o indivíduo como sendo orientado situacionalmente;

3) visualizar holisticamente as experiências do indivíduo;

4) focalizar os aspectos cognitivos envolvidos;

5) analisar sistematicamente a individualidade das pessoas; e

6) empregar maior orientação qualitativa (DERVIN e NILAN, 1986).

As bases desta nova abordagem são:

- o processo de se buscar compreensão do que seja "necessidade de informação" deve ser analisado sob a perspectiva da individualidade do sujeito a ser pesquisado;

- a informação necessária e o tanto de esforço empreendido no seu acesso devem ser contextualizados na situação real onde ela emergiu; 
- o uso da informação deve ser dado e determinado pelo próprio indivíduo (CHEN e HERNON, 82).

Nesse sentido, TAYLOR (1986) defende a idéia de se enfocar, prioritariamente, nos estudos alternativos, o problema individual dos usuários. Que informação um indivíduo quer encontrar no sistema de informação, que uso fará dela, e como o sistema pode melhor ser projetado para preencher essas necessidades de informação dependerão exclusivamente dele próprio, de seu propósito na busca de informação, e do uso da mesma na transposição de lacunas (JAMES, 1983).

Informação é essencialmente vista como uma ferramenta valiosa e útil para os seres humanos em suas tentativas de prosseguir com sucesso suas vidas. Conforme o indivíduo se move através do tempo e do espaço, assume-se que ela tanto pode descrever como predizer a realidade, e na verdade permite ao indivíduo mover-se de modo mais eficiente.

Segundo ROUSE e ROUSE (1984, p. 129), o ser humano raramente busca informação como um fim em si mesma. Ao contrário, ela e parte de um processo de tomada de decisão, solução de problemas ou alocação de recursos. Porém, a própria atividade de se "buscar informação" e um processo em si mesmo. Um processo dinâmico onde métodos e critérios utilizados para selecionar ou rejeitar informações variam freqüentemente no tempo (KRIKELAS, 1983), dependem dos resultados imediatos (ROUSE e ROUSE, 1984), são fortemente relacionados com os hábitos pessoais do indivíduo (CHILDERS, 1982) e com as necessidades que precisam ser satisfeitas (BROWN, 1991).

Esta perspectiva de processo dinâmico, envolvido por um processo maior, denota sua complexidade e requer que a abordagem da busca de informação humana seja feita de maneira muito mais ampla do que vinha sendo adotada por aqueles que estudam o processamento de informação humana e o design de sistemas. Dessa base conceitual, KRIKELAS (1983) define o comportamento de busca de informação "como uma atividade de um indivíduo empenhado em identificar uma mensagem para satisfazer uma necessidade percebida".

Portanto, qualquer tentativa de descrever padrões de busca de informação deve admitir o indivíduo como o centro do fenômeno, e considerar visão, necessidades, opiniões e danos desse indivíduo como elementos significantes e influentes que merecem investigação. Necessidades de informação, ainda, devem ser definidas em plano individual, destacando-se atenção para o tempo e o espaço específicos experimentados pelo elemento em particular.

Embora as pessoas tenham suas próprias experiências, subjetivas e únicas, enquanto estão se movendo no tempo e espaço, existe também grande similaridade entre 
situações encontradas pelos diferentes indivíduos. Portanto, necessidade de informação não é um conceito subjetivo e relativo, o qual existe somente na mente de um indivíduo. Ao contrário, representa um conceito intersubjetivo com significados, valores, objetivos etc. passíveis de serem compartilhados. Um conceito que permite a identificação e generalização de padrões de comportamento de busca e uso de informação através do tempo e do espaço sob a ótica do usuário (DERVIN e NILAN, 1986).

A abordagem alternativa, ao posicionar informação como algo construído pelo ser humano, esta visualizando o indivíduo em constante processo de construção, livre para criar o que quiser junto aos sistemas ou as situações. Essa abordagem se preocupa em entender como pessoas chegam à compreensão das coisas, pesquisando por dimensões passíveis de generalizações dessa tomada de consciência (ou de compreensão), e ainda em identificar o processo de uso da informação em situações particulares.

Enquanto estudos tradicionais examinam os sistemas apenas através das características grupais e demográficas de seus usuários, os alternativos estudam as características e perspectivas individuais dos usuários. Pesquisas anteriores provam que os atributos demográficos (sexo, idade, raça, religião, renda familiar) não são indicadores potenciais do comportamento de busca e uso da informação. O uso exclusive deles contribuí para que sejam ignoradas as mudanças temporais e espaciais que ocorrem no cotidiano dos indivíduos. (DERVIN e NILAN e JACOBSON, 1981; ATWOOD e DERVIN, 1982; DERVIN e NILAN, 1986).

Essa abordagem alternativa foi empregada primeiramente nas Ciências Sociais e a posterior na Comunicação e informação.

Na área da Ciência da informação, tal abordagem tem sido trabalhada em diferentes vertentes:

a) Abordagem de "Valor Agregado" de Robert Taylor (User-Values ou Value-Added,1984).

b) Abordagem do "Estado de Conhecimento Anomalo" de Belkin e Oddy (Anomalous States-of-Knowledge, 1978).

c) Abordagem do "Processo Construtivista" de Carol Kuhlthau (Constructive ProcessApproach, 1992).

d) Abordagem Sense-Making de BrendaDervin (1977,1983, 1993, 1994).

Enquanto as abordagens de Taylor, Belkin \& Oddy e Kuhlthau têm contribuído com argumentos conceituais e teóricos profundos para um paradigma alternativo em estudos de usuários, Dervin apresenta um método bastante elucidativo para mapear necessidades de informação sob a ótica do usuário. Tem sido amplamente utilizado para tal fim, desde final da década de 70 . 
O embasamento teórico a ser utilizado para a concepção deste estudo das necessidades de informação de usuários da rede eletrônica do Instituto de Física da USP, é tomado do Sense-Making Approach. A seguir, apresenta-se descrição mais pormenorizada dessa abordagem.

\subsubsection{Sense-Making Approach}

Essa abordagem consiste em pontuações de premissas teóricas e conceituais e outras tantas de metodologias relacionadas, para avaliar como pacientes / audiências / usuários / clientes /cidadãos percebem, compreendem, sentem suas interações com instituições, mídias, mensagens e situações, e como usam a informação e outros recursos neste processo. (DERVIN, 1977, 1980, 1981, 1983a, 1983b, 1994, 1995).

Tem como foco o fenômeno do sense-making, definido amplamente em termos de uma serie de suposições ontológicas e epistemológicas ${ }^{2}$. È compreendido, neste estudo, como a atividade humana de observação, interpretação e compreensão do mundo exterior; inferindo-lhe sentidos lógicos, advindos do uso dos esquemas interiores. $\mathrm{Na}$ introdução do Cap. 1 foi iniciada discussão sobre tal conceito.

DERVIN (1993a, p.2) define essa atividade tanto como um comportamento interno (i.é., cognitivo), como externo (i.e., atitudes, reações face ao meio social) que permite ao indivíduo construir e projetar seus movimentos, suas a9oes através do tempo e espaço. A busca e uso de informação, portanto, e central para tal atividade.

Optou-se por utilizar o termo em inglês "Sense-Making", dado que tal neologismo não tem correspondente ainda no idioma nacional. A tarefa de defini9ão de inequívoca expressão a língua portuguesa e tarefa difícil que deve envolver estudos lingüísticos e semânticos. Não sendo este o propósito desta tese.

A abordagem Sense-Making foi iniciada em 1972, pela Professora Dra. Brenda Dervin, Ph.D. em Ciências da Comunicação, docente do Departamento de Comunica96es da Ohio State University, na cidade de Columbus, EUA. Mas, somente em maio de 1983, na International Communications Association Annual Meeting em Dallas, TX, USA, e publicado o documento contendo sua base filosófica, conceitual, teórica e metodológica (DERVIN, 1983a). Vários outros documentos do gênero foram sendo publicados ao longo dos anos. (DERVIN, 1993; SHIELDS et all, 1993; DERVIN, 1994).

\footnotetext{
${ }^{2}$ Conforme mensagem eletrônica, recebida recentemente da Profa. Brenda Dervin, seu grupo de seguidores instituiu, desde final do ano de 1994, o uso de letras maiúsculas para se referir a abordagem e minúscula para o fenômeno.
} 
Dervin e seus seguidores tem verificado a crescente adoção da abordagem do "SenseMaking", tanto nas áreas de comunicação, informação e biblioteconomia, como na educação, assistência social e psicologia. A titulo de ilustração, somente na base de dados do Social Science Citation Index, em julho de 1994, foram identificados 450 citações sobre tal abordagem.

Tem sido empregada em estudos desenvolvidos com amostras desde 20 a cerca de 1000 elementos, principalmente: teses de doutoramento, pesquisas acadêmicas, projetos encomendados, estudos empíricos, entre outros. De maneira geral, as aplicações abrangem grande variedade de contextos (em pesquisas de opinião publica sobre política, processos de comunicação na área da saúde, estudos sobre imagens organizacionais, recepção de audiência, e recentemente em uso de telecomunicações) e a uma variedade de níveis analíticos (individual, grupal, organizacional, comunitário, cultural).

A base conceitual do "Sense-Making" foi desenvolvida com suporte na teoria de vários estudiosos: como BRUNER \& PIAGET (cognição); KUHN \& HABERNAS (constrangimento das Ciências tradicionais e alternativas); ASCROFT; BELTRAN \& ROLINS (teórica critica); JACKINS \& ROGER (terapia psicológica) e principalmente em CARTER, teórico da comunicação, afirmando que o homem cria idéias para transpor as lacunas que Ihes são apresentadas em decorrência da descontinuidade sempre presente na realidade.

Os enunciados básicos da abordagem do Sense-Making, segundo Dervin (1983a), podem ser sinteticamente apresentadas como:

a) a realidade não é completa nem constante, ao contrário, e permeada de descontinuidades fundamentais e difusas, intituladas lacunas. Assume-se que esta condição e generalizável porque as coisas na realidade não são conectadas e estão mudando constantemente.

b) a informação não e algo que exista independente e externamente ao ser humano, ao contrário e um produto da observação humana.

c) desde que se considera a produção de informação ser guiada internamente, então o Sense-Making assume que toda informação e subjetiva

d) busca e uso da informação são vistas como atividades construtivas, como criação pessoal do sentido individual do ser humano.

e) focaliza em como indivíduos usam as observações, tanto de outras pessoas como as próprias para construir seus quadros da realidade e os usa para direcionar seu comportamento.

f) o comportamento dos indivíduos pode ser prognosticado com mais sucesso com a estruturação de um modelo que focalize mais suas "situações de mudanças" do que atributos denominados características de personalidades ou demográficas. 
g) pesquisa por padrões, observa mais do que assume conexões entre situações e necessidades de informação, entre informação e uso.

h) considera-se a existência de "compreensões universais da realidade" que permita prognósticos e explicações melhores do que seria possível obter nas abordagens positivistas tradicionais.

Levando em conta esses enunciados, vários métodos foram desenvolvidos pelo Sense-Making, para entrevistar os usuários, coletar e analisar os dados obtidos.

DERVIN (1983a), metaforicamente, representa o estado cognitivo do ser humano como o movimento continue, sempre em frente, como em uma estrada, ou seja, no tempo e no espaço. A posição atual do indivíduo, ao longo desta caminhada, é função de onde já esteve (experiências, ambientes etc.), de onde está (no presente ) e para onde vai (future).

Descreve-os como criaturas inteligentes e criativas, capazes de compreender o sentido das coisas, através da incorporação de conhecimento tanto advindo do mundo exterior como dele próprio. Quando não tem dúvidas ou indecisões quanto as suas necessidades, os indivíduos se movem continuamente em direção aos seus objetivos. Entretanto, lacunas aparecem frequentemente. A ponte necessária para transporás e função das estratégias empregadas pelos indivíduos para buscar e utilizar as fontes potenciais de informação, isto é, para solucionar o problema.

A figura 1 representa graficamente o que se descreveu até então.

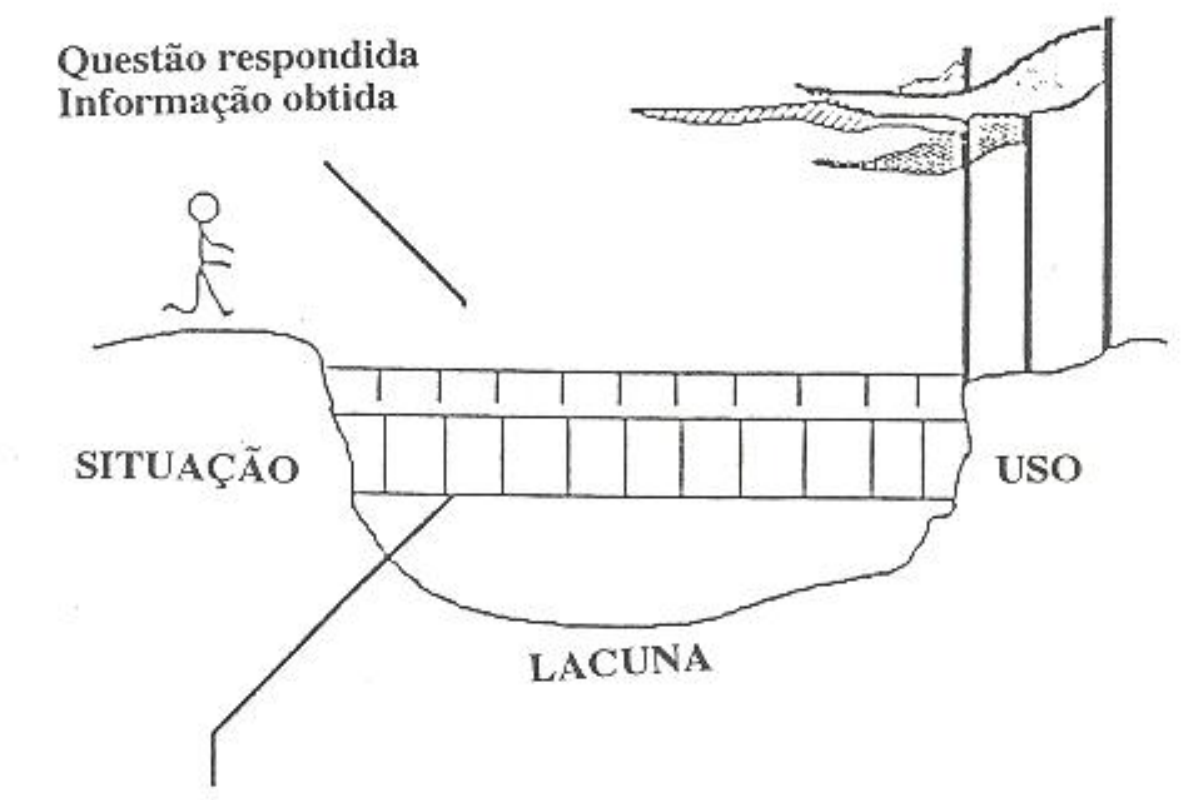

Estratégias utilizadas

FIGURA 1 - A metáfora do "Sense-Making" (DERVIN, 1992, p.69) 
A metáfora operacional acima submerge diretamente da idéia da descontinuidade. Assume-se que o ser humano passa por várias etapas em suas experiências. Cada momento e considerado novo, mesmo que seja repetição de comportamentos passados, e sempre teoricamente uma nova etapa porque ocorre em um momento diferente no tempo e no espaço.

Como o indivíduo interpreta e transpõe este momento? Quais estratégias usa para solucionar a situação na qual defrontou-se com a lacuna? Como interpreta esse problema e as possibilidades de resolvê-lo? Como se move taticamente para isso? Como reinicia sua Jornada? Eis algumas das formas de compreensão buscadas pelo Sense-Making.

Metáfora que gerou o modelo de DERVIN, conhecido como modelo de três pontas, construído sobre o trinômio situação-lacuna-uso, e demonstrada na Figura 2.

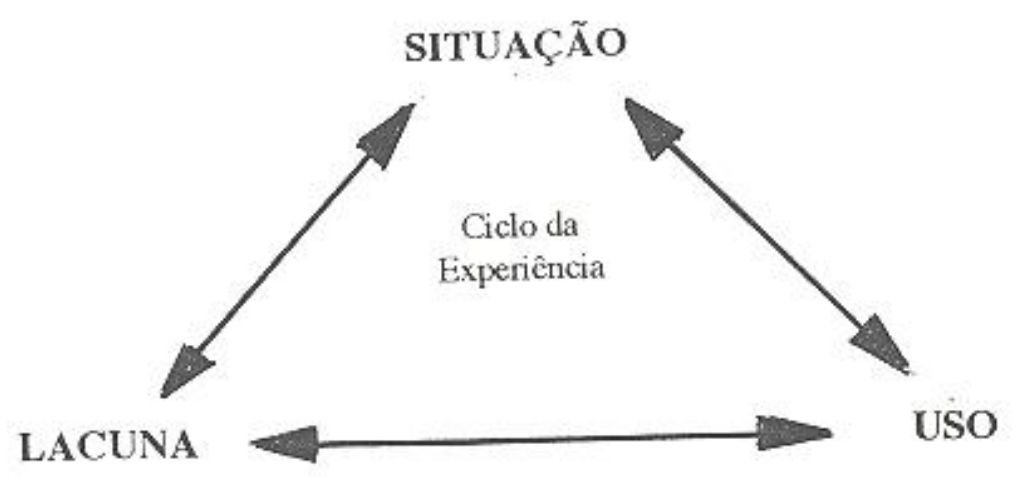

\section{FIGURA 2 - O trinômio do "Sense-Making"}

(DERVIN, 1992, p.69)

Percebe-se, por esta figura, que conforme o indivíduo se move na vida, passa por várias etapas, onde cada uma em particular pode apresentar novas lacunas, novas buscas, novos usos e assim consecutivamente.

A situação e o componente mais abrangente deste modelo. é o contexto temporal e espacial no qual surge a necessidade de informação, estabelece-se o período em que a busca e uso da informação vai ocorrer, e se chega (ou não) a compreensão do problema. DERVIN coloca uma situação de necessidade de informação como aquela em que o senso interno individual tende a se esgotar, e a pessoa deve criar novo senso. Situação e algo que esta sempre mudando com o tempo. (DERVIN e NILAN, 1986, P-21).

O indivíduo, no contexto de alguma situação, encontra uma serie de lacunas, i.e, pontos que o usuário não compreende ou compreende apenas em parte, e que o leva a interromper seu caminho. Pode ser definida como a situação problemática, 
um estado anômalo de conhecimento (BELKIN, ODDY \& BROOKS, 1982), um estado de incerteza (KRIKELAS, 1983), uma situa5§o na qual um indivíduo esta tentando chegar à compreensão de alguma coisa (DERVIN, 1983a). É conseqüência direta da perspectiva tida por Dervin sobre a visão humana da realidade, a qual interpreta como sendo algo intersubjetivo e constantemente em mudança. Conceitualmente, a lacuna representa uma oportunidade de a informação auxiliar o indivíduo a continuar seu caminho.

O indivíduo e, então, levado a fazer algum tipo de uso de qualquer ponte que seja construída para transpor a lacuna defrontada por ele. Uso, portanto, e o emprego dado ao conhecimento recém-adquirido, traduzido na maioria dos estudos de usuários como a informação útil (DERVIN, 1983a).

Desta forma, ao se tentar estudar e compreender como determinada pessoa percebe sua condição, esta abordagem assume ser imprescindível avaliar esses três pontos básicos: situação, lacuna e uso como uma base mínima para auto-orientação. Somente assim se estará respeitando o fato de que pessoas percebem o mundo diferentemente (Dervin, 1994).

O emprego desta abordagem em estudos de comportamento de busca e uso da informação, pressupõe também a aceitação dos seguintes atributos:

a) individualidade - usuários devem ser tratados como indivíduos e não como conjunto de atributos demográficos;

b) situacionalidade - cada usuário se movimenta através de uma única realidade de tempo e espaço;

c) utilidade da informação - diferentes indivíduos utilizam a informação de maneira

própria, e informação é o que auxilia a pessoa a compreender sua situação;

d) padrões - analisam-se as características individuais de cada usuário, intentando-se chegar aos processos cognitivos comuns à maioria.

A abordagem do Sense-Making propõe a idéia da lacuna, tanto como uma suposição teórica, como uma estrutura para guiar o método de elaboração das questões a serem utilizadas nas pesquisas, a forma de condução das entrevistas empregadas e o tipo de análise a submeter os dados coletados.

De modo a operacionalizar seu modelo, Dervin desenvolveu uma técnica através da qual os usuários constroem um timeline (doravante traduzido para "cronograma").

Esse cronograma intenta conduzir o usuário a reconstru9§o de um quadro referencial, observando o local e o tempo dos acontecimentos. Alguns autores intitulam esse quadro de "matriz cognição x ação". Nele e descrita a seqüência de acontecimentos (intitulados eventos), que ocorrem em dada situação. 
Essas situações são operacionalizadas como o contexto, ou cenários nos quais o usuário necessita informação.

Os eventos são operacionalizados como cenas momentâneas da situação do usuário, similares as imagens congeladas de um filme. Eles são etapas no cronograma.

lacunas são operacionalizadas como questões ou devidas que os usuários concebem em um evento particular.

Usos são operacionalizados como o modo com que as respostas a essas questões auxiliam, ou não, a solução das necessidades de informação, em um dado evento de uma situação.

O modelo de Dervin permite a cada pessoa representar sua própria realidade. $\mathrm{Na}$ verdade, a teoria Sense-Making e um processo humano criativo de compreensão do mundo em um ponto particular no tempo e espaço, limitado pela capacidade psicológica e, ainda, dos acontecimentos presentes, passados e futuros de cada indivíduo. Focaliza um ponto no tempo em que a informação é necessária. Neste estudo, em particular, a situação envolve o uso das redes eletrônicas, em especial a informação eletrônica.

\subsection{AMBIENTE DE BUSCA E USO DA INFORMAÇÃO}

Existem alguns fatores importantes que influenciam as necessidades de informação dos usuários, os quais ALLEN (1969) chama de "modelo dos fatores influenciáveis". Os tipos mais comuns são características e atributos, que incluem experiência, faixa etária, nível educacional, estilos cognitivos e orientação individual (PAÍSLEY e PARKER, 1967; PENLAND, 1976; WARNER e MURRAY e PALMOUR, 1973; MICK e LINDSEY e CALLAHAN, 1980; FORD, 1983; DERVIN, 1989).

O comportamento do usuário e suas preferências pessoais, i.e., hobbies, interesses e atividades de lazer também são determinantes de necessidades de informação (MICK, LINDSEY \& CALLAHAN, 1980).

Entretanto, a maioria dos estudos aponta a profissão do usuário como o mais importante e influente fator para determinar necessidades de informação. E chamado de círculo concêntrico, por PAÍSLEY (1980), incluindo área de assunto; atividades, interesse e hábitos profissionais e ambiente de trabalho.

Alguns estudos mostram que para o usuário buscar e usar informação, ele deve primeiro estar consciente dos serviços e produtos de informação disponíveis em seu ambiente (PRINGGOADSURYO, 1984; RIEGER e ANDERSON, 1968). As necessidades de informação são também influenciadas pela organização dos sistemas, abrangência do conteúdo temático disponível, incluindo formato, quantidade e 
atualização das informações (GAINS, 1978; CHEN e HERNON, 1982; PRINGGOADIRUYO, 1984)

Fatores determinantes de freqüência de uso dos serviços de informação ou de fontes específicas de informação estão relacionados com a percepção que os usuários têm quanto às facilidades e acessibilidades para usá-los, incluindo custos, riscos, acessibilidade, proximidade geográfica, disponibilidade de múltiplas fontes de informação e de canais de comunicação tanto formais como informais (KENNEY, 1966; ORTON e WISEMAN, 1977; GAINS, 1978; CHEN e HERNON, 1980; MICK e LINDSEY e CALLAHAN, 1980; FISHER, 1982; PRINGGOADISURYO, 1984; FIGUEIREDO, 1994).

"Informação" e "necessidades de informação" são conceitos utilizados com diferentes conotações. CRAWFORD (1978) e FORD (1980) já os cunhou, anteriormente, como sendo termos difíceis de serem definidos, isolados e medidos.

DERVIN, em sua abordagem Sense-Making, visualiza informação como sendo o elemento capaz de fornecer somente descrição parcial da realidade, só se completando quando parte do quadro individual de referenda, do processo essencialmente interior. Não e algo que exista externamente, por si só. Embora possa parecer redundante, a pesquisadora conceitua informação como sendo "aquilo que informa", isto e, algo que o indivíduo pode ativamente compreender, inteligentemente construir a realidade, e criativamente decidir sobre sua utilidade em uma dada situação. E fazendo uso da informação que o indivíduo consegue transpor as lacunas que aparecem no seu caminho. (DERVIN, 1977, 1980, 1983a).

Pessoas buscando e usando informação são as que podem estar querendo reduzir incertezas, informar-se, instruir-se, escapar de uma situação, constatar uma realidade, obter suporte social (DERVIN, 1976); fazer progresso em uma situação difícil (ZWEIZIG, 1979), ou mesmo compreender sua a9oes no tempo e no espaço (DERVIN,

1983a). Busca e uso de informação, portanto, são vistos como forma de processo construtivo de compreensão individual e pessoal (DERVIN, JACOBSON, NILAN,1982).

WILSON (1981) já descreve "necessidade e uso de informação" como um processo de tomada de decisão, solução de problemas ou alocação de recursos. Outros complementam essa idéia, mencionando que busca e uso "não são um fim em si mesmo, e que informação e somente um meio para auxiliar os usuários a tomar decisão, solucionar problemas ou localizar recursos" (FAIBISOFF e ELY, 1976; ROUSE e ROUSE, 1984).

Discussões e argumentos sobre as defini9oes desses dois termos constituem ate hoje literatura especializada extensa na Ciência da informação, Comunicação, Informáticas outras. Embora muita atenção esteja sendo dada a questão 
conceitual, o progresso tem sido lento e, segundo ROUSE e ROUSE (1984), ambos são termos considerados dinâmicos, tendendo a se modificar de tempos em tempos.

Entretanto, para o propósito deste trabalho, a fim de delimitar questões operacionais da investigação, faz-se necessário assumir uma definição para alguns conceitos.

\subsubsection{Definições de Pesquisa}

Apoiada na ideologia de Brenda Dervin, daqui em diante entender-se-ão:

- NECESSIDADE DE INFORMAÇÃO como a ponte entre "busca" e "uso" da

informação, assumindo que o usuário esta consciente de sua necessidade de dados, fontes e recursos e uso da informação obtida para transpor problemas, lacunas. Portanto, necessidade de informação e entendida como fase construtiva individual, quando a pessoa compreende determinadas situações, em um dado momento no tempo e no espaço (DERVIN, 1983a).

- BUSCA DA INFORMAÇÃO como atividade claramente desenvolvida pelo usuário em razão da localização de respostas as suas questões. Tem relação com os tipos de fontes a serem utilizadas e/ou buscadas para solução dos problemas, e com as estratégias empreendidas.

- USO DA INFORMAÇÃO como o emprego dos dados obtidos ou da informação

consumida para se chegar à compreensão da situação, transpor a lacuna existente e retomar o seu movimento.

- INFORMAÇÃO como o elemento informativo que permite ao indivíduo transpor

lacunas, levando-o a compreensão da situação e a realização de seus intentos. Entretanto, a informação não tem valor por si mesma. O indivíduo a selecionara e dar-lhe-á significado, decidindo se pode ou não ser utilizada para transpor aquela lacuna.

- TEMPO e ESPAÇO como a dimensão que envolve a noção de passado (por onde o individuo esteve), de presente (onde o indivíduo está) e de futuro (para aonde o indivíduo se encaminha). É calcada na compreensão de que as necessidades dos indivíduos variam no tempo e no espaço. Significa dizer: as necessidades de informação diferem de um momento para outro, de uma situação para outra e de pessoa a pessoa (DERVIN, 1979). 
Neste estudo, a linha básica regendo o comportamento de busca e uso de informação repousa no fato de que indivíduos, em ambiente acadêmico, se deparam com situa95es onde necessitam responder questões, localizar um fato, solucionar um problema, compreender alguma coisa ou tomar decisões de modo a prosseguir sua caminhada. Estas situações podem, ou não, estar levando esses indivíduos a utilizarem as redes eletrônicas. 
PARTE III

ESTUDO DE NECESSIDADES

DE
INFORMAÇÃO 


\section{Capítulo 4}

\section{COMPORTAMENTO DE BUSCA E USO DA INFORMAÇÃO VIA REDES ELETRÔNICAS}

Estudo no Instituto de Física da USP

Ambiência do Instituto de Física da USP. Serviços de divulgação e informação via redes eletrônicas. Descrição dos passos metodológicos da pesquisa de campo. 


\section{PRELIMINARES}

O relato deste estudo esta apresentado em duas partes principais. A primeira descreve a ambiência do Instituto de Física da Universidade de São Paulo (IFUSP) e engloba:

- breve histórico das Ciências Físicas no país e na USP, o nascimento do Instituto, sua distribuição geográfica, unidades componentes e números de docentes, pesquisadores, alunos e funcionários, procurando caracterizar os usuários da rede eletrônica local;

- sucinto relato dos acontecimentos prévios que concorreram para a implantação do atual Centro do Computação do IFUSP, com descrição pormenorizada dos serviços on-line que oferecem;

- descrição dos primórdios do Serviço de Biblioteca e Informação do IFUSP e detalhamento dos serviços de informação oferecidos aos usuários, implementados via rede eletrônica.

O desenvolvimento desta parte se baseia tanto em revisões do documentos e publicações do próprio Instituto como também em entrevistas semi-estruturadas recaídas entre final de 1994 e inicio de 1995. Essas entrevistas incluíram pessoal técnico e administrativo de Centro de Computação, do Serviço de Biblioteca e Informação, da Assistência Técnica para Assuntos Acadêmicos, da Assistência Técnica para Assuntos Administrativos e usuários da rede local (docentes alunos e funcionários). A observação direta da pesquisadora, principalmente nas atividades de utilização dos serviços da rede IFUSP, também forneceu informações importantes.

A segunda parte se refere especificamente à pesquisa de campo, a qual visa analisar o comportamento de busca e uso da informação dos diferentes tipos de usuários da rede de IFUSP. Essa parte engloba:

- descrição da população em estudo, procedimento de pesquisa, variáveis, descrição da técnica de coleta de dados e planejamento do instrumento de pesquisa utilizado;

- resultados obtidos, análise e interpretação dos mesmos.

A metodologia adotada para a coleta de dados foi o emprego de um instrumento especialmente elaborado e enviado a população selecionada, via correio eletrônico. Tal instrumento foi adaptado da técnica desenvolvida por Brenda Dervin, intitulada Time Line Interview, de modo a atingir os objetivos propostos nesse estudo.

Descrições detalhadas a respeito dessa técnica estão inseridas a seguir no item 4.2.3. 


\subsection{AMBIÊNCIA INSTITUCIONAL: O INSTITUTO DE FÍSICA DA USP}

\subsubsection{Breve Histórico da Física no Brasil}

Da mesma forma que outras Ciências, a Física tem como fim o conhecimento objetivo da Natureza. Nesse sentido, ela sempre foi praticada em grau maior ou menor em qualquer época. Teve grande impulso a partir do Renascimento, com expressivas contribuições para o conhecimento na Idade Moderna, quando os físicos partindo do sistema planetário heliostático em oposição ao geocêntrico conseguem formular teorias e modelos matemáticos do movimento dos astros, dos projéteis ou dos corpos em queda livre. Foi no final do sec. XVII, porem, que surgiram as bases para a mecânica clássica com suas três leis básicas e a lei da gravitação universal. No decorrer dos séculos XVIII e XIX, a Física foi conquistando outros territórios, como a Acústica, a Termodinâmica, a Mecânica Estatística, a Óptica c o Eletromagnetismo (FERRI \& MOTOYAMA, 1979).

No Brasil, somente após a vinda da família real portuguesa em 1808 é que começou, lentamente, o desenvolvimento da Física, pois a infra-estrutura implantada na época colonial propiciava uma sociedade agrária, fundada no latifúndio escravista, pouco ou quase nada afeita a atividade científica. Segundo BASSALO (1990), "... a Ciência Brasileira só começou a dar seus primeiros passos autônomos a partir das duas ultimas décadas do século XIX, quando alguns problemas relacionados à Agricultura e a Saúde brasileiras fizeram com que se criassem organismos para desenvolver a pesquisa nesses campos, tais como, o Instituto Agronômico de Campinas (1887), o Instituto Bacteriológico (1893) c o Instituto Butantã (1899), em São Paulo, e o Instituto de Manguinhos (1900), no Rio de Janeiro". Porem, pesquisa em Física são se institucionalizou no Brasil na década de 30.

Até essa data, professores interessados em Física, familiarizados com matemática e algum senso de experimentação, iniciaram, embora precariamente, disciplinas na área, em cursos de Engenharia Civil da Escola Militar (1839) e nas escolas médicas do Rio de Janeiro, no Museu Nacional (1820). Na segunda metade do século XIX, o número de pessoas em contato com a Física havia aumentado consideravelmente, devido à criação de novas instituições de caráter técnico ou educacional e, ao findar o século, quando se da uma rápida expansão do Ensino Superior por todo o Brasil, inicia se a formação de um ambiente salutar e mais propicio a Física (FERRI \& MOTOYAMA, 1979, p.70). 
Durante os primeiros trinta anos do século XX, a Física fortaleceu seu espaço, merecendo atenção por parte de estudiosos famosos, desenvolvendo-se em várias e diferentes frentes de pesquisas, culminando com sua institucionalização no país em dois lugares distintos: São Paulo - com a criação, em 1934, da Faculdade de Filosofia, Ciências e Letras da Universidade de São Paulo (FFCL/USP) e no Rio de Janeiro - com o Instituto Nacional de Tecnologia em 1934 e a Faculdade Nacional de Filosofia (FNF), em 1939.

\subsubsection{A Física na Universidade de São Paulo}

A Universidade de São Paulo, criada pelo então Governador Armando Salles de Oliveira, no dia 25 de Janeiro de 1934, foi baseada no modelo francês de Universidade, o qual tinha, como célula mater, uma Faculdade de Filosofia, Ciências e Letras (FFCL).

$\mathrm{Na}$ concepção original dessa Faculdade, havia a iddia de transferir para si todas as cadeiras básicas de fundamentação científica, de todas as escolas profissionais existentes na época. Formar-se-iam assim dois níveis de atividades acadêmicas: um, destinado a aplicação da ciência e a formação profissional de professores; o outro, superposto a este, cobrindo o conjunto das especializações científicas necessárias ao primeiro, mais uma série de ramos científicos considerados essenciais ao "saber humano".

Para o desenvolvimento da Ciência foram instituídos diferentes

departamentos; instalaram-se laboratórios relativamente bem equipados, oferecendo condições satisfatórias de trabalho e, sobretudo, foram fixados salários em bases condizentes. A FFCL contratou, também, cientistas nos centros mais avançados da Europa para dirigir e orientar pesquisas. Assim e que chegou ao Brasil o físico ítalo-russo Gleb Wataghin (1899-1986), da Universidade de Turim, para organizar o Departamento de Física da FFCL/USP e iniciar, a partir de 1935, o curso de Bacharelado em Física (SCHWARTZMAN, 1979,p.207)

Wataghim e seus colaboradores iniciaram linhas de investigações na USP, tanto pertinentes a Física Teórica como a Física Experimental. Destaque especial foi dado as investigações sobre raios cósmicos. Na segunda metade da década de 30, outros trabalhos foram realizados na FFCL/USP, tais como os de natureza teórica sobre a interação dos elétrons, as equações inomogêneas de movimento na Mecânica Quântica, as regras de seleção nos raios beta e teoria de mésons, além de vários outros, lançando o Brasil como um dos países-lider em pesquisa pioneira no campo da Física (BASSALO, 1990, p. 14). 
Durante o período em que o Brasil participou da $2^{a}$ Guerra Mundial (1938- 45), as atividades científicas do grupo de Física da FFCL/USP cederam lugar as atividades tecnológicas dentro do esfor9o de guerra brasileiro. Foram desenvolvidos sistemas de sonar, para proteger os navios brasileiros dos submarinas do Eixo. com o termino da Guerra, a Marinha deixou de se interessar pela continuidade das pesquisas tecnológicas, o grupo retornando as suas atividades acadêmicas e científicas (SCHWARTZMAN,1979, p. 258).

Porém, o clima de euforia que tomou conta de toda a Física, em especial da Física Nuclear em todo o mundo após a 2a Guerra, em virtude da bomba atômica, parece ter-se refletido, também no Brasil. Desse modo, ocorre enorme esforço para desenvolver a Física Nuclear, particularmente na área experimental.

A FFCL/USP apresenta as melhores condições para instalação de aceleradores por possuir um grupo de físicos experimentais de alto nível. com a vantagem de esses especialistas já estarem trabalhando nesse campo ha. algum tempo e de terem projetado e construído equipamentos com circuitos elétricos e eletrônicos, necessários também para casas novas máquinas. Assim, em 1948 c adquirido o acelerador nuclear Betatron e, em 1955, o Gerador Eletrostático. A Física dos Materiais levou a instalação do primeiro Microscópio Eletrônico (1948) c, alguns anos depois, o primeiro liquefator de Hélio, no laboratório de Física do Estado Sólido c Baixas Temperaturas (FERRI \& MOTOYAMA, 1979).

Em 1970, com a Reforma Universitária, e oficialmente instituído, na

Universidade de São Paulo, o Instituto de Física, reunindo os Departamentos de Física da Escola Politécnica (em atividade desde os anos 50) c da Faculdade de Filosofia, Ciências c Letras. Por aquela ocasião, visando atender a interesses tanto políticos como temáticos de pesquisa dos então componentes do Instituto, foram estruturados 3 departamentos de Ensino e Pesquisa: Física Geral c Experimental, Física Nuclear c Partículas Elementares, e Física de Materiais e Mecânica.

Essa organização perdura ate início dos anos 80, quando o Departamento de Física Nuclear e Partículas Elementares se divide em Física Nuclear e Física

Matemática. Uma terceira modificação ocorreu em outubro de 1993. O Departamento de Física Geral subdividiu-se em: Geral, Experimental e Aplicada.

O Instituto atualmente manchem em sua estrutura organizacional e administrativa:
a) Órgãos colegiados (Congregação e Conselho Técnico-Administrativo),
b) Comissões (de Ensino de Graduação, de Pós-Graduação, de Apoio Profissional, de Avaliação de Cursos e Supervisora do Centro de Computação)
c) Diretoria Geral, 
d) Unidades de Apoio:

Serviço de Biblioteca e informação e o Centro de Computação,

e) Departamentos de Ensino e Pesquisa:

Física Experimental (FEP),

Física Aplicada (FAP),

Física Geral (FOE),

Física Matemática (FMA),

Física dos Materiais e Mecânica (FMT) e

Física Nuclear (FNC).

\section{DEPARTAMENTOS DE ENSINO E PESQUISA}

Com exceção do Departamento de Física Matemática, que e exclusivamente voltado a pesquisa teórica, os outros departamentos desenvolvem tanto pesquisas de cunho teórico como experimental. Para tanto, contam com vários laboratórios de física experimental, física nuclear, detetores e instrumentação, física do estado sólido e baixas temperatura, física de plasma, cristalografia, ótica, epitaxia de feixes moleculares, microscopia eletrônica, biofísica, poluição do ar, análise de materiais por feixes iônicos, entre outros. Contam, ainda, com infraestrutura técnica e administrativa própria, incluindo oficinas mecânicas, eletrônicas, de alto vácuo e instalações de computação em linha e para cálculos matemáticos complexos.

Os diversos docentes, técnicos e alunos vinculados a cada departamento vêm se agrupando também em função dos interesses temáticos comuns. Essa praxe fez surgir vários grupos de estudo em tópicos específicos, com a mesma estrutura e posição no organograma institucional dos laboratórios. Por exemplo, no Departamento de Física Experimental existem os Grupos de Óptica de Cristais Líquidos e de Física Nuclear Teórica, no Departamento de Física Geral encontram-se vários grupos, entre eles o de Biofísica e Física Médica, e assim por diante.

\section{CURSO DE GRADUAÇÃO E LICÊNCIATURA}

O Instituto de Física vem oferecendo, desde 1993, várias modalidades de cursos:

a) Bacharelado em Física

Permite ao aluno escolher currículos com ênfases diferentes, tais como: Bacharelado em Física, Habilitação em Pesquisa Básica, Habilitarão em Física aplicada e 
Instrumentação (com possibilidade de aprofundamento na direção da Microeletrônica) e Habilitação em Oceanografia Física.

Ao Bacharelado e as Habibilitações do Bacharelado correspondem disciplinas obrigatórias em várias áreas, como Física Teórica Básica, Física Experimental, Química e Matemática. Paralelo a essas, são oferecidas várias disciplinas optativas, tanto de responsabilidade do próprio Instituto, como de outras unidades - Instituto Astronômico e Geofísico, Instituto de Matemática e Estatística, Instituto de Geociências, Instituto Oceanográfico, Instituto de Química e Escola Politécnica, dentre outros da USP.

b) Licenciatura em Física

O currículo de Licenciatura tem por objetivo principal a formação de professores de Física para o $2^{\circ} \mathrm{Grau}$, podendo, ainda, orientar sua formação para outras áreas de interesse.

Oferece formação geral em Física, cobrindo amplamente matérias teóricas, tanto clássicas como contemporâneas. Dentre os critérios necessários ao currículo de licenciatura, encontram-se disciplinas em Física, Matemática, Química, Educação, Instrumentação para o Ensino de Física, entre outras. Disciplinas especificas da área de Educação, são oferecidas pela Faculdade de Educação da USP.

O total de alunos de Graduação e Licenciatura no Instituto é por volta de 1

900 estudantes. Anualmente, 260 vagas são oferecidas, sendo 100 para a Licenciatura e 160 para o Bacharelado, divididos igualmente entre os cursos matutinos e noturnos.

\section{CURSO DE POS-GRADUAÇÃO}

O Instituto de Física mantém programas de Pos-Graduação em:

a) Física - sub-áreas Física Nuclear, Física do Estado Solido, Física de Partículas

Elementares - Mestrado e Doutorado; e em

b) Ensino de Ciências - modalidade Física cujo programa c supervisionado em conjunto com a Comissão de Pos-Graduação da Faculdade de Educação. No IF só é oferecido o Mestrado; o Doutorado e de responsabilidade da Faculdade de Educação, porém seus alunos são aceitos no IF como alunos especiais em disciplinas eventuais.

Segundo Relatório da Comissão de Pós-Graduação, datado de outubro de 1994, o Instituto mantém o seguinte número de pós-graduandos: 
Mestrado Doutorado

EM FÍSICA

- Alunos especiais

- Alunos regulares

EM ENSINO DE CIÊNCIAS

- Alunos especiais

- Alunos regulares

Sintetizando aqui os dados quanto ao corpo de professores, alunos e funcionários, estima-se que o IFUSP atualmente conte com aproximadamente 184 docentes (sendo 11 Assistentes, 103 Doutores, 38 Associados e 32 Titulares); 1900 alunos de graduação (bacharelado e licenciatura); 500 alunos de pós-graduação, 151 técnicos de apoio ao ensino e pesquisa e 198 técnicos operacionais e administrativos. O Instituto mantém, ainda, um grupo de pesquisadores em programa de pós-doutoramento, porem, pelas normas vigentes na Universidade ate final de 1994, não se tinha nenhum registro desses elementos, tornando impossível sua quantificacão ${ }^{1}$.

\subsubsection{Processo Histórico do Pólo Computacional do IFUSP}

A história do desenvolvimento da rede local no IFUSP tem estreita

relação com o Departamento de Física Nuclear, o qual, em 1986, adquira um computador VAX 780 c instala uma rede entre vários terminais, compartilhando esse equipamento com os demais departamentos.

Assim quando, em agosto de 1989, a FAPESP se conecta a BITNET via HEPNET², o IFUSP já se encontrava em plena condição de interligar-se aquele órgão de fomento. Estabelece-se imediatamente conexão direta, e o Instituto torna disponível, aos docentes e alunos, comunicação eletrônica em nível internacional, sendo uma das primeiras ligações universitárias no país.

com o crescimento exponencial das redes, o aparecimento cada vez mais acelerado de tecnologias novas e avançadas, bem como do número de interessados em utilizar esse novo recurso, torna-se premente a necessidade de se estruturar um serviço

\footnotetext{
${ }^{1}$ com a Resolução $n^{\circ} 4140$ de 20/12/94, o programa de pós-doutoramento na USP e regulamentado. Os indivíduos, neste regime, passam a ter direito a uma serie de serviços prestados pela universidade. Esta, por sua vez, terá maior controle do número e credenciais de pesquisadores atuando nos vários institutos e departamentos.

${ }^{2}$ Rede High Energy Physics, a qual esta vinculado o laboratório FERMLAB em Chicago, EUA. Essa rede e DECnet, ou seja, rede em que se utiliza exclusivamente equipamentos e protocolos da empresa americana Digital Equipment Corporation.
} 
específico de atendimento, manutenção, controle e organização dessa rede. Dessa movimentação decorre a implantação, em 1990, do Centro de Computação do Instituto de Física da USP (CCIFUSP), vinculado diretamente a sua Diretoria, com objetivo de implementar e gerenciar a rede local de computadores. Nesse mesmo ano e adquirido um computador VAX 6330 da Digital Equipment Corporation, e instalada a rede Ethernet de fibra ótica.

Em seu projeto inicial, foi atribuição do CCIFUSP conectar por fibra ótica (4 cabos) cada uma das salas de computação já existentes nos Departamento, Prédios e Blocos do Instituto. A partir dali, cada unidade se encarregou do planejamento e distribuição das interconexões internas, utilizando cabeamento fino (8 fibras).

Praticamente todos os professores possuem os micros de seus escritórios de trabalho conectados a rede. Também os alunos têm ampla facilidade de acesso, tanto através das várias salas de computação dos Departamentos, como nas próprias salas destinadas as pesquisas de pós-graduação.

Quando, em 1992, o Centro de Computação Eletrônica da USP inicia a instalação de fibra ótica entre os institutos da Universidade, o IF passa a acessar por intermédio daquele centra a rede Internet, mantendo ainda, por mais algum tempo, sua ligação direta com a FAPESP. Pode-se dizer que a rede do Instituto é bastante heterogênea, pois contém equipamentos de plataformas variadas, de portes diferenciados e ainda com gerenciamento descentralizado, muito embora a coordenação geral seja do Centro de Computação. A rede do IF d, atualmente, no tanto das redes Internet, DECnet como da RENPAC (a qual foi instalada para facilitar aos usuários o acesso por Modern). Mas não e um nó da BITNET, conectando-se através do gateway da FAPESP.

Implantada para melhorar a comunicação entre pesquisadores e aumentar a produtividade da pesquisa, pode-se assegurar que a rede local do IF d exclusivamente destinada a pesquisa ${ }^{3}$. Atende aproximadamente 688 usuários, sendo uma das maiores da Universidade, e possui os seguintes equipamentos interligados:

- 01 roteador de interface com a USPNet, via fibra ótica(router);

- 20 transceivers tipo thick cable (TEG);

- 06 bridges Ehemet;

- 06 multi-repetidores Ethernet, com saída para 8 segmentos tipo thin cable (MRC/8);

- 02 repetidores Ethernet duais para segmento (DRC/1);

- 04 repetidores óticos (RO);

- 300 metros de cabo coaxial grosso (thick cable);

- 5000 metros de cabo coaxial fino (thin cable);

- 900 metros de fibra ótica;

- 04 computadores mainframe;

- 34 estações de trabalho, totalizando 20 Gbytes de área em disco;

${ }^{3}$ Toda as atividades administrativas do IF continuam sendo incorporadas a rede administrativa da USPASTIR. 
- 27x-terminais;

- 13 estações diskless;

- 221 microcomputadores.

\section{POLITICA DE USO DA REDE}

Todos os docentes do Instituto são automaticamente cadastrados como usuários da rede, recebendo sua senha e endereço eletrônico imediatamente; os demais integrantes têm sua inclusão vinculada à solicitação de algum docente. No caso de pós-graduandos, exige-se pedido formal por parte do orientador, o mesmo ocorrendo com alunos de graduação em programas de iniciação científica. Dentre os funcionários, os TE (Técnicos de Apoio ao Ensino), participando de projetos de pesquisa, também dependem de auto-rixarão dos docentes, enquanto que os TO' (Técnicos Operacionais e Admmistrativos) estão sendo inseridos de maneira mais seletiva.

Todas as senhas distribuídas têm validade por um ano, necessitando nova solicitação para sua prorrogação (exceto os docentes). Contas não utilizadas por mais de 6 meses são automaticamente bloqueadas.

O CCIFUSP mantém controle esporádico de uso e, eventualmente, desenvolve cstatisticas de utilização de recursos da rede local.

O aceso externo ao IF por Modern é feito via RENPAC, utilizando-se tarifação reversa, ou seja, custeada pelo instituto. Os docentes têm esse acesso garantido, ficando bastante restrito seu uso para alunos.

A rede local do IFUSP, conectada a USPNet e, via FAPESP, a rede nacional e internacional de computadores, permite a utilização de vários recursos/serviços, entre eles: Mail, Set Host I Telnet, Copy Remote I FTP, Gopher, WWW, WAIS.

E norma da rede que todo novo usuário receba automaticamente como peneiras mensagens cópia dos últimos boletins eletrônicos publicados pelo CCIFUSP e, principalmente, o folheto eletrônico "USPIF Services", que traz descrição detalhada de todas as atividades disponíveis via rede local, equipamentos disponíveis, instruções de uso, endereços mais importantes e as "Regras para a Utilização dos Computadores do IFUSP" documento que estabelece os procedimentos óticos e básicos necessários ao bom desempenho individual.

\section{Serviços de divulgação de Informação via Rede}

Uma característica bastante marcante da rede local do IFUSP e sua grande contribuição a comunidade nacional e internacional, visto sua opção de tornar-se um 
servidor de informação em geral, tanto interna como externamente. Seu papel, portanto, tem sido bastante ativo no que se refere a serviços de extensão a comunidade.

Várias atividades foram sendo implementados. Para gerenciamento delas, foi instituída a "Companhia das Informações - CIA-INFO", definida como "um centro de serviços via rede que visa disponibilizar informações diversas em níveis nacionais e intemacional" (USP/IF, 1994).

Dentre os serviços disponíveis, encontram-se:

\section{a) Sinopses dos jornais do dia}

Diariamente são divulgadas sinopses nas áreas de Ciências e Tecnologia, de maneira geral, de artigos advindos de vários jornais nacionais (O Estado de S. Paulo, Jornal do Brasil, O Globo, Correio Braziliense, entre outros).

\section{b) Informes sobre concursos, oportunidades de emprego}

Semanalmente são divulgadas informações sobre concursos em diversas áreas e em instituições variadas como órgãos públicos e privados.

\section{c) Diretório de serviços disponíveis nas redes brasileiras}

De maneira bastante sistemática, a CIA-Info vem coletando, armazenando, organizando, disseminando informações sobre os inúmeros serviços de Gopher, W W VV, listas de discussão e outros, mantidos pelas várias instituições nacionais conectadas a Internet ou BITNET.

\section{d) Cadastre de services disponíveis na rede mundial}

O objetivo é centralizar informações sobre os principais serviços existentes na Internet. Prioritariamente, aqueles que servem como guia ou diretório para outros serviços, dentro daquela rede, de modo a se ter pontos de partida para buscas mais aprofundadas.

\section{e) Lista de nodes brasileiros}

Uma das maiores dificuldades das redes eletrônicas e a localização dos nodes existentes e seu endereço correto. Visando sanar essa barreira, o CCIF mantém um cadastro com seus respectivos endereços, ordenado alfabeticamente. 


\section{f) Informações sobre a BRAS-NET 4}

A Cia-INFO do CCIFUSP vem trabalhando no sentido de ampliar e manter atualizado um guia criado inicialmente por Geraldo Xexeo e Andre Valentev primeiros usuários da BRAS-NET.

O objetivo e manter um banco de dados, no qual as informações mais frequentemente procuradas sobre a BRAS-NET, sejam localizadas de forma resumida, funcionando tanto como fonte de referenda e consulta simples e ágil, bem como introdução aos iniciantes, ou os que pouco conhecem sobre o funcionamento de listas de distribuição de mensagens.

\section{g) Distribuição de boletins eletrônicos}

A Cia-INFO vem elaborando e circulando vários boletins eletrônicos, os quais periodicamente são distribuídos, isentos de taxas, a quaisquer usuários das RE (Internet, BITNET, HEPNET, e outras), interessados em recebê-los. Tais boletins são:

- Services - BR divulga relação de todos os serviços brasileiros, disponíveis na RE;

- BRAS - NOTICIAS - BR compila notícias veiculadas na imprensa nacional

- BRAS -ESPORTES circula informações sobre os esportes nacionais;

- CONCURSO - BR dissemina os dados mais recentes inseridos no serviço de

informes sobre concursos, oportunidades de emprego, entre outros.

\section{h) Lista das "Listas de Discussão" nacionais}

Implantado recentemente, este serviço visa oferecer aos usuários das redes brasileiras um meio rápido de se manter atualizado sobre as várias listas de discussão / distribuição de mensagens existentes atualmente no país.

As informações mantidas nesse catálogo são atualizadas continuamente, conforme as mensagens são recebidas pelas instituições mantenedoras de cada lista. Sua organização e em ordem alfabética pelo nome da mantenedora e sigla das listas. Em Janeiro de 1995, já haviam sido cadastradas mais de 300 listas mantidas por cerca de 22 instituições nacionais.

\section{i) Acesso a bases de dados nacionais e internacionais, via Gopher e W W W}

Através de seus serviços interativos gopher e WWW (acessíveis via telnet ou cliente MOSAIC e recentemente Netscape), vêm possibilitando acesso a várias bases de dados nacionais, como a Base de Dados Tropical (TDB) da Fundação Andre Tosello

\footnotetext{
${ }^{4}$ BRAS-NET e uma lista de distribuição de mensagens eletrônicas, reunindo estudantes, pesquisadores, professores profissionais em geral, distribuídos por todo o mundo. A grande maioria dos membros são brasileiros e boa parte dos assuntos abordados refere-se ao Brasil. Tópicos diversos são discutidos, tais como política, Ciências, esportes, humor e outras informações diversas.
} 
em Campinas; várias bases do Centro de Recursos em Bioinformática da EMBRAPA, DEDALUS - Banco Bibliográfico da USP e bases da UNICAMP, UFRGS, RNP em vários estados, entre outras.

\section{j) Serviços de busca de pessoas e endereços na Internet}

A única instituição nacional a oferecer o serviço de localização de instituições /ou pessoas e respectivos endereços eletrônicos, na rede Internet, via servidor Netfind, e o Instituto de Física. Utilizando conexão remota (login= Netfind.if.usp.br), e possível realizar pesquisas, via menu e palavra-chave, em uma grande variedade de base de dados. Embora não muito simples para se utilizar, tem se mostrado um serviço bastante util. As vantagens principais de se ter um servidor desse tipo instalado no Brasil são a diminuição do trafego internacional e maior velocidade de acesso as bases de dados. Outro serviço de localização de pessoas, também disponível no IFUSP, e o Whois, acessível por telnet e/ou FTP.

\section{k) Serviço de auxílio personalizado de auxílio à busca de endereços eletrônicos}

Além de oferecer os aplicativos Netfind e Whois, com os quais os usuários buscam por si próprios as informações que desejam, o CCIFUSP mantém uma central de atendimento personalizado (isto é, pessoa a pessoa). Esse serviço recebe pelo correio eletrônico mensagens em linguagem natural, as quais após análise são encaminhadas ao postmaster 5 brasileiro mais adequado para atender a demanda. Para tanto, mantém um cadastro dos postmasters existentes e dispostos a dar suporte sempre que necessário.

Todos esses serviços oferecidos pela CIA-Info do CCIFUSP estão disponíveis online através de vanos recursos, dependendo de suas características. As diversas formas de acesso são periodicamente divulgadas no Boletim "Guia do Servidor de Noticias do IFUSP" e são ainda enviadas às diversas listas de discussão: ANSP-L,

CNPq-L, Redes-L e outras. Os serviços prestados pela Cia-Info tem uso comercial vetado.

De maneira geral, as informações referentes a esses serviços podem ser acessados por Fileserv, FTP, Listserv, Gopher e W W W.

Paralelos a todas essas atividades de extensão a comunidade em geral, o CCIFUSP manter também serviços direcionados especificamente a comunidade local: docentes, alunos, pesquisadores e funcionários do Instituto.

\footnotetext{
${ }^{5}$ Postmaster - elemento responsável pelo gerenciamento do correio eletrônico nas redes de comunicação.
} 
Os Serviços a Comunidade Acadêmica são:

\section{a) Repositório para FTP anonymous}

O CCIFUSP mantém um banco de dados contendo várias informações, textos, softwares e aplicativos tanto de domínio público na área de Física como de interesse específico para usuários do VAX. Esse reposit6rio, muito embora estruturado com o fim básico de auxiliar usuários locais, também pode ser acessado externamente.

\section{b) Servidor News}

Baseado na estrutura funcional do USENET, esse servidor foi implantado visando tornar disponíveis a seus usuários internos:

- informações e explicações sobre todos os serviços e boletins eletrônicos da CialNFO.

- noticias e eventos diversos, em decurso, no próprio Instituto de Física.

- documentação eletrônica especificamente preparada para orientar os usuários sobre os procedimentos, auxílios, instruções online referentes aos comandos básicos e serviços específicos tanto da rede local como das redes internacionais.

De forma automática, esse Servidor e oferecido aos usuários a cada LOGIN, ou seja, sempre que se estabelece um processo interativo no VAX. Em caso de interesse o usuário entra com o comando específico (seguindo instruções mostradas na tela) e recebe imediatamente relação das várias opções disponíveis. Atualmente, existem 71 folders cobrindo informações bibliográficas (sumário de 45 revistas técnico-científicas de interesses), grupos de discussão, informações sobre o IF, novidades nas áreas de Física e Informática e arquivos de FAQ7 sobre vários temas.

\section{c) Distribuição de Pre-print}

Já ha bastante tempo, o Setor de Publicações do IF vem organizando, coletando, editando os pre-prints do Instituto e os distribuindo entre várias instituições interessadas, tanto nacionais como internacionais.

Seguindo exemplo de outras universidades estrangeiras, esse setor vem reformulando suas estratégias, de modo a tornar publico, também eletronicamente, através de um repositório de FTP anonymous, esse acervo. As vantagens desse novo procedimento são diminuir custos de impressão e correio convencional, facilitar e agilizar o acesso

\footnotetext{
${ }^{6}$ Esse serviço e prestado em conjunto com o Setor de Atendimento ao Usuário da Biblioteca do IFUSP e será mais detalhado no item 4.2.2.2

7 FAQ - Frequently Asked Questions, são coleções de perguntas e respostas mais freqüentes sobre determinado tópico. Quase todos os newsgroups têm as FAQ.
} 
as pesquisas do IFUSP a um número maior de interessados e possibilitar pesquisa e recuperação em todo o acervo.

Por outro lado, aos usuários foi oferecida a possibilidade de acessar pre-prints de. pesquisadores estrangeiros através de "Serviços de Quadro de Avisos - BBS" disponíveis nas seguintes áreas: Geometria Algébrica, Astrofísica, Matéria Condensada, Análise Funcional, Relatividade Geral e Cosmologia Quântica, Física de Altas Energias Fenomenológicas, Física de Altas Energias Teóricas (Formal) e Física Nuclear Teórica. Os inscritos em um (ou mais) desses BBS recebem diariamente uma relação de pre-prints, com seus respectivos resumos. A solicitação de cópia do texto completo e via correio eletrônico, sendo o pedido atendido em questão de minutos. Tendo em vista que a divulga ao de préprints é uma prática comum entre físicos de todo o mundo, esses novos serviços eletrônicos vem recebendo crescente atenção. Por exemplo, somente na área de Física de Altas Energias Teóricas já existiam mais de 2000 inscritos em abril de 1994.

\subsubsection{Participação do Serviço de Biblioteca e Informação do IFUSP}

O Serviço de Biblioteca e Informação do IFUSP tem origem na década de 60 junto a Faculdade de Filosofia, Ciências e Letras. Quando da reforma universitária e implantação do atual Instituto de Física, o acervo em Física, bem como todas as atividades e serviços existentes, são transferidos da FFCL constituindo-se a Seção de Biblioteca do IFUSP.

Com a reestruturação administrativa ocorrida na USP em 1986, em função do detalhado estudo de estrutura organizacional para as bibliotecas uspianas proposto pelo Departamento Tdenico do Sistema de Bibliotecas (SIBI), essa Seção sofre alterações.

Fica instituído o Serviço de Biblioteca e informação/SBI, vinculada a Diretoria Técnica de Serviços, a qual por sua vez responde diretamente ao Diretor do Instituto, e assessorada por um docente coordenador de Biblioteca, integrando-se ao SIBI. Organiza-se nas seguintes subdivisões:

- Serviço de Aquisição e Tratamento da informação englobando o Setor de Prepare de Dados para Automação, e

- Serviço de Atendimento ao Usuário, agregando o Setor de Referenda.

Por essa ocasião existia o Setor de Documentação em Física Nuclear, instalado no Departamento de Física Nuclear, que foi incorporado ao SBI em final de 1993. 
O acervo do Serviço de Biblioteca e especializado no campo da Física e Ciências afins, formado principalmente por monografias, periódicos, relatórios tecnicocientfficos, catálogos de universidades nacionais e estrangeiras, dissertações e teses do. IFUSP, de outras unidades da USP e de outras instituições de ensino do Brasil e do exterior.

Seus usuários regulares são docentes, discentes e funcionários do IFUSP. Porém, podem ser inscritos também alunos e professores de outras unidades da USP, pesquisadores vinculados aos Grupos de Estudos Especiais, bolsistas do exterior, professores visitantes e pesquisadores de outros centres de pesquisa, desde que indicados por docentes locais.

Trabalhando em estreita ligação com os analistas do CCIFUSP, o Setor de Atendimento ao Usuário vem iniciando uma série de atividades e serviços utilizando-se das facilidades das RE.

Dentre elas, encontram-se:

\section{a) Auxilio ao usuário via correio eletrônico}

Através desse recurso, usuários locais e/ou externos se comunicam com a biblioteca solicitando as mais variadas informações sobre o acervo, material bibliográfico específico, referenda bibliográfica exata, fotocópias de artigos, envio de sugestões e outros.

\section{b) Controle eletrônico de empréstimo de material}

Também por meio do correio eletrônico, o Setor de Empréstimo mantém seus usuários informados dos materiais em reserva, novas aquisições e atrasos na devolução dos mesmos.

\section{c) Sumario de periódicos incluídos no Servidor News do CCIFUSP}

Dentre as informações veiculadas no News encontram-se sumários correntes de 46 principais títulos de periódicos assinados pela Biblioteca, selecionados em conjunto com o professor-coordenador. Quinzenalmente, esses sumários são atualizados, de acordo com a chegada de novos fascículos. Aos usuários é possível se inscrever, via rede, para receber quais e quantos títulos queiram.

\section{d) Disseminação seletiva de informações (DSI eletrônico)}

Já há algum tempo o Centre de Computação Eletrônica (CCE/USP) vem oferecendo acesso online, via USPNet, a base de dados do Current Contents with Abstracts, em várias áreas. Utilizando-se dessa iniciativa, o Setor de Atendimento ao Usuário, com a colaboração do analista de sistema do CCIFUSP, desenvolveu um programa capaz de, periodicamente, pesquisar aquela Base na área de Física e elaborar listagens com 
referências bibliográficas e resumes, para cada um dos usuários inscritos no DSL Para tanto, o programa compara os termos indexados, em determinados campos da base de dados, com os perfis individuais (os quais são pré-estabelecido em função das áreas, de interesse indicadas pelos usuários). Essa listagem e enviada ao interessado em forma impressa, disquete ou pelo correio eletrônico. Em dezembro de 1994, este Serviço atendia 60 usuários entre docentes e alunos de pós-graduação, e ainda alguns usuários externos que estejam desenvolvendo projetos em colaboração com professores do IFUSP.

\section{e) Cadastre da produção científica atualizado online}

Ainda utilizando a base do Current Contents, o Setor vem atualizando seu banco de dados de produção científica do Instituto.

\section{f) Acesso remoto aos bancos de dados de editoras}

Atualmente, várias editoras internacionais estão oferecendo gratuitamente aos usuários de biblioteca que mantém assinaturas de seus periódicos impressos, acesso, pesquisa $r$ cópia online à suas bases de dados. Essas bases contêm tanto os sumários de suas publicações como os artigos na Integra. Para isso, a biblioteca deve proceder ao cadastramento individual dos interessados e orientá-los quanto às formas de acesso. Esses procedimentos estão em implantação a Biblioteca do IFUSP.

Do mesmo modo, várias obras de referenda veiculadas através de publicações periódicas, anteriormente em formato impresso, vêm sendo agora colocadas a disposição através de FTP anonymous.

\section{g) Treinamento de profissionais da informação}

O Sistema de Bibliotecas da USP- SIBI iniciou no $2^{\circ}$ semestre de 1994 esforços no sentido de alertar e treinar os profissionais de informação para o uso das RE, evidenciando suas possibilidades e benefícios. Para isso, um grupo de estudo intitulado "Grupo de Usuários da Internet" vem trabalhando para desenvolver esse treinamento a contento.

Tendo em vista o adiantado avanço da rede local do IFUSP, já com vários serviços implantados e da crescente participação dos profissionais da biblioteca, foi natural que a bibliotecária responsável pelo Setor de Atendimento ao Usuário do Instituto participasse daquele grupo e, ainda, que se oferecesse a proporcionar várias demonstrações de suas atividades e serviços aos profissionais das outras unidades da USP.

De maneira bastante sucinta procurou-se dar uma idéia das inúmeras possibilidades de acesso a diversificadas informações que vem sendo oferecidas pelo 
Centro de Computação e Biblioteca do Instituto de Física. A evolução histórica do Instituto e sua situação atual - em termos de estrutura física e organizacional, corpo docente e discente, bem como a infra-estrutura computacional - evidenciam quão desenvolvida se encontra esta unidade da USP, em termos de redes eletrônicas.

Atualmente, com referencia as instalações de redes, o Instituto vem se dedicando ao planejamento de projetos de expansão de hardware \& software. A intenção primeira e implantar o Sistema UNIX em toda a rede, tanto devido ao caráter universal deste, como principalmente para não continuar se restringindo a apenas uma plataforma. A aquisição de um servidor UNIX para o CCIFUSP e vários menores para cada um dos departamentos, interligados por fibra ótica, protocolo FDDI e melhoramento da rede Ethernet, estabelecera conexões mais rápidas e apropriadas.

\subsection{PESQUISA DE CAMPO: BUSCA E USO DA Informação VIA REDES ELETRÔNICAS}

\subsubsection{Paradigma Adotado: Base da Pesquisa}

A fundamentação que norteia esta pesquisa de campo é a "abordagem entrada no usuário"; especificamente o Sense-Making, amplamente empregada para mapear comportamentos de busca e uso da informação partindo de perspectivas individuais. O objeto d estudar particularmente cada usuário da rede local do Instituto de Física da USP, para se chegar à generalização dos comportamentos do grupo como um todo.

Os trabalhos de NILAN et al (1989), TESSIER (1981), DERVIN et al (1982), DERVIN (1983a), DERVIN e NILAN (1986), NILAN et al (1990), SCHAMBER et al (1990) e SCHAMBER (1991) fornecem o fundamento para a conceituação, instrumentação e medidas do comportamento desses usuários. As revisões da literatura sobre redes eletrônicas e estudos de usuários, apresentadas nos capítulo 2 e 3 deste documento, são também apoio para a determinação do referencial teórico.

Retomar pontos principais da abordagem selecionada como esteio desta pesquisa, aqui e agora, faz-se necessário. Isso irá clarear e fortalecer importantes itens embutidos quando da coleta, tratamento e análise dos dados.

DERVIN (1983a) metaforicamente representa o estado cognitivo do ser humano como um movimento continue no tempo e no espaço ao longo de uma estrada. Lacunas ou problemas freqiientemente aparecem no decorrer dessa caminhada e são interpretados como a necessidade do ser humano em "tomar Ciência" do mundo antes que 
o próximo passo seja empreendido. Lacunas são conseqüências diretas da perspectiva de DERVIN (1983a) sobre a visão humana da realidade subjetiva e em constante mudança. Essas lacunas são interpretadas como a ausência de algum conhecimento ou dado, que gera no indivíduo uma necessidade de informação e cria uma expectativa sobre a melhor forma para se transpô-las.

De maneira geral, Sense-Making e definida por Dervin (1983a) como o comportamento interne e/ou exteriorizado através dos sentidos, o que permite ao indivíduo construir e projetar seu movimento através do tempo e do espaço. Vem sendo empregada para estudar como os indivíduos percebem o sentido do seu mundo e, em particular, como eles constroem as necessidades e uso de informação nesse processo.

A informação e o fator que auxilia o usuário a compreender a situação e transpor problemas, tendo, portanto, importância capital. Neste estudo, informação será operacionalizada como a "resposta" recebida pelo usuário individual para aquela sua questão específica. Os vários atributos da informação a serem observados são:

a) as fontes de informação: o contexto espacial onde se localiza a resposta a sua questão em um dado momento. Neste estudo, serão analisadas tanto as fontes que efetivamente foram auxílios ao usuário (fontes institucionais, pessoais, impressas, eletrônicas, bibliográficas, entre outras) como os recursos informacionais cogitados e utilizados na busca de auxílio.

b) os caminhos de obtenção da informação: procedimentos empregados para se obter

respostas a questão, em um ponto específico no tempo. Serão operacionalizados como o esforço percebido na busca da resposta, as atitudes do indivíduo para encontrá-la, o grau de completeza havendo a clã, as estratégias utilizadas para sua obtenção e a satisfação com o resultado final.

A busca da informação se mostra tanto nos comportamentos para localização das respostas as questões surgidas, como nas fontes utilizadas para tanto. E o processo de uso da informação corresponde ao auxílio esperado e ao recebido com a resposta.

Considerando o modelo de três pontas do Sense-Making, baseado no trinômio situacão-lacuna-uso, neste estudo esses conceitos são operacionalizados da seguinte forma:

a) situação: e o contexto ou o problema que gera no usuário uma necessidade de informação, levando-o a utilizar a rede eletrônica;

b) lacuna: e a questão mais significativa colocada pelos usuários, representava de suas necessidades de informação, num momento especifico; 
c) uso: e tanto a expectativa de uso (idealizada pelo usuário quanto à informação recebida com a resposta a sua questão), como o uso real - o que foi realmente realizado, ou não, com a resposta.

Paralelos ao estudo de comportamento dos usuários, foram também empenhados esforços para se determinar seus conhecimentos, habilidades e os procedimentos usuais na identificação, localização, acesso e recuperação de informações via rede.

\subsubsection{Variáveis}

Empregando a abordagem do Sense-Making, pretendeu-se investigar se e como usuários da rede local do Instituto de Física da USP estão sanando suas necessidades de informação quando da utilização de redes eletrônicas de comunicação.

Analisar as possibilidades de os usuários selecionados estarem realmente visualizando a rede como fonte de informação em potencial envolve identificar 0 conhecimento que possuem dos variados recursos e serviços disponíveis, habilidade no manuseio dos comandos, compreensão quanto aos propósitos, dificuldades e barreiras existentes no uso das RE. Saber o modo como os usuários estão se comportando quando buscam informações através da rede envolve análises de suas necessidades de informação, dos processos de busca e uso de informação e da informação propriamente dita.

A operacionalização e análise das diversas variáveis em estudo foram pautadas em função de 16 tópicos. Sendo os 6 primeiros voltados à análise dos conhecimentos dos usuários e os demais, ao comportamento real quando usando as RE:

01 tempo de experiência com computadores e, em específico, com cada uma das redes internacionais as quais o Instituto de Física tem acesso;

02 freqüência de uso de vários serviços e aplicativos disponíveis na RE;

03 propósitos de uso das redes;

04 barreiras encontradas no seu manuseio;

05 dificuldades percebidas no acesso a informação via RE;

06 treinamentos para uso de RE;

07 situação ou contexto que levou o usuário a usar a rede;

08 espectro das questões colocadas pelos usuários, classificadas quanto à natureza e o foco; 09 uso esperado das respostas as questões colocadas pelos usuários;

10 estratégias empregadas para obter respostas as questões colocadas pelos usuários;

11 fontes que, de algum modo, auxiliaram o usuário; 
12 recursos informacionais que, de maneira geral, foram utilizados pelo usuário;

13 esforço empreendido pelo usuário na tentativa de obter resposta a sua questão;

14 importância avaliada na obtenção da resposta as suas perguntas;

15 completeza percebida nas respostas obtidas; e

16 análise das questões colocadas pelos usuários, mas não solucionadas.

A tipificação dos usuários da rede do IFUSP - em termos de grau acadêmico, sexo, idade, formação mais recente, bem como a determinação de sua dispersão geográfica dentro do próprio Instituto também foi considerada.

\subsubsection{Técnica de Coleta de Dados}

Basicamente para se coletar dados para tal estudo, foi necessária uma adaptação da técnica desenvolvida por Brenda Dervin intitulada The Micro-moment Time Line Interview.

Essa técnica - ponto central na abordagem Sense Making - foi escolhida por fornecer um controle bastante rigoroso e metódico das três características básicas envolvidas na representação da necessidade de informação, quais sejam: a situação, as lacunas e o uso da informação, observados tanto no contexto temporal como espacial. Sua meta e generalizar os padrões de comportamento de busca e uso dos indivíduos (DERVIN, 1983a).

É um procedimento metodológico que permite ao usuário narrar minuciosamente suas experiências, utilizando suas próprias palavras, sem nenhuma imposição por parte do pesquisador. Evidência, portanto, a percepção que cada usuário tem quanto às alterações de seus movimentos.

A técnica TimeLine apresentada originalmente utiliza entrevistas individuais, pedindo a cada informante para descrever em detalhes, passo a passo, o ocorrido em uma dada situação. Cada um desses passos e, então, analisado separadamente tentando elencar o rol de questões apresentadas pelo informante. Essas questões formalizam a tentativa do indivíduo em buscar algum dado, aprender algo, compreender melhor, ou fazer sentido da sua realidade.

Após a identificação de todas as questões ocorridas nas diversas etapas, procede-se as suas análise sem profundidade, uma a uma. Geralmente, os itens detalhados nessa análise medem as variáveis que estão sendo investigadas na pesquisa, tais como: completeza das respostas, fontes utilizadas, estratégias de busca, uso esperado, e outros dados. 
Pesquisas utilizando essa técnica têm sido aplicadas a grande variedade de contextos, como usuários de bibliotecas públicas buscando informações utilitárias; integrantes de bibliotecas especializadas procurando suporte para o desenvolvimento de propostas de projetos de pesquisas, em sistemas de informação multimídia usando dados geográficos; doadores de sangue em situação de doação; alunos de graduação em recentes conflitos interpessoais; desenvolvimento de pessoas com deficiência física em situação de dificuldades; crianças e problemas de relacionamento com shows de TV; universitários produzindo monografias, entre outros (DERVIN, 1983a; NYLAN e FLETCHER, 1990; PANNEN, 1990; GLUCK, 1992)

Diversificada também tem sido a forma empregada para se abordar os diferentes contextos vivenciados pelos indivíduos através dessa técnica. Algumas pesquisas focalizam a situação mais recente, ou a mais importante, a mais traumática, mais difícil etc. Também modo utilizado para identificar e analisar as questões tem variado, podendo-se trabalhar com todas as questões, evento por evento, ou delimitar um número prefixado delas, ou ainda, trabalhar com uma única questão do tipo: as transmitidas a terceiros ou as interiorizadas; as mais importantes; as que obtiveram sucesso ou fracasso, e outras.

Para o propósito deste estudo, a técnica do Time Line sofreu adaptações. Ao invés de entrevistas pessoais com os usuários da rede do IFUSP, optou-se por estruturar um instrumento de coleta de dados, de tal modo organizado, que os levasse a relatar os pormenores de uma situação de uso recente das redes eletrônicas. Após pré-teste, o instrumento foi encaminhado aos usuários da rede do IFUSP através do correio

eletrônico, solicitando devolu9\&o do mesmo modo.

Esse é um dos pontos chave da metodologia desenvolvida. Como a intenção da pesquisa e perscrutar o comportamento de busca e uso de informação em ambiente de comunicação eletrônica, nada mais natural que fossem utilizados seus próprios recursos para esta empreitada.

Outra conven9ão adotada nesta pesquisa foi a de se trabalhar com a situação mais recente de uso da rede eletrônica para solução de problemas, dificuldades ou localização de respostas a perguntas, ou seja, situações envolvendo informação. Há que se observar aqui, a semelhança existente com a técnica do "incidente crítico"8, já utilizada nas Ciências humanas e sociais há anos.

Finalmente, adotou-se também centrar o estudo na questão mais significativa ocorrida com o usuário, segundo sua própria perspectiva, naquela situação mais recente. Salienta-se, portanto, que o estudo e evidentemente pontual, tendo em vista

8 Incidente crítico consiste em indagar-se do indivíduo sendo questionado uma lembrança de alguma experiência ou acontecimento recente relevante (FIGUHREDO, 1979). 
que analisa em profundidade uma dada necessidade de informação, em um determinado contexto e em um exato momento no tempo.

Neste estudo, a análise mais detalhada das questões apresentadas pelos usuários compreende os nove itens finais do instrumento de coleta de dados, os quais obviamente analisam as três variáveis: situação, lacuna e uso da informação. Alguns desses itens são abertos e outros fechados. Assim, os que abordam critérios de completeza da resposta obtida, satisfação e esforço dispendido são itens fechados utilizando escalas ordenadas como mínimo, regular e grande/máxima, enquanto a resposta obtida e avaliada em parcial, completa e excessiva.

O trabalho de coleta de dados foi efetuado durante um período de dois meses. A primeira sene de mensagens, contendo a carta-convite e o instrumento, foi enviada diretamente pelo encarregado do sistema do Centra de Computação de Instituto de Física a todos os componentes da rede, com instantes para devolução deste diretamente á pesquisadora via email. Porém, como alguns usuários solicitaram auxílio individual, foi estabelecido um roteiro de visitas. Dois usuários que preferiram receber os instrumentos impressos foram também atendidos.

\subsubsection{Instrumento de Coleta de Dados}

O instrumento de coleta de dados foi planejado para evidenciar, em detalhes, o comportamento de busca e uso da informação por integrantes da rede local do IFUSP.

Estruturado em três blocos, o instrumento contém ao todo 25 itens através dos quais o informante fornece dados pessoais, opiniões sobre a RE e ainda pormenores de uma recente experiência de uso na busca de informações (Apêndice A). Ao final do instrumento, destinouse um espaço para outros comentários a respeito de suas vivências com as RE ou mesmo avaliação sobre o instrumento de pesquisa. Maiores detalhes sobre os três blocos do instrumento estão incluídos a seguir:

\section{Dados de identificação}

Visa categorizar demograficamente a população de estudo quanto ao sexo, idade, formação acadêmica de mais alto nível e também vinculação com o próprio Instituto (aluno, docente, funcionário graduado e pesquisador). São sete itens, todos abertos.

\section{Conhecimento e uso dos recursos disponíveis nas redes}


Objetiva identificar a habilidade dos usuários no manuseio das redes, suas experiências com computadores, freqüência de uso dos recursos e serviços disponíveis nas redes, dificuldades encontradas tanto no manejo das redes como no acesso \& informação por seu intermédio, formas de aprendizagem e, finalmente, suas percep95es quanto aos propósitos e utilidades desse recurso eletrônico. Contém 7 itens abertos e apenas 1 fechado.

\section{Situação recente de uso da rede eletrônica}

Trata mais especificamente dos conceitos pré-determinados na abordagem alternativa, esteio deste trabalho, qual seja o Sense Making Approach. Intenta, pois, determinar o padrão de comportamento de busca e uso da informação dentre os usuários da rede de computadores do IFUSP.

São doze itens inter-relacionados (três fechados e nove abertos), visando levar o usuário a descrever, com suas próprias palavras e de acordo com sua perspectiva, detalhes de uma situação de uso das RE. Cada um desses itens está sendo pormenorizado a seguir.

\section{Item 3.1-Características situacionais temporais e espaciais.}

Solicita-se ao usuário que tente relembrar às vezes em que utilizou a rede eletrônica para solucionar algum problema, resolver uma dificuldade ou localizar respostas a perguntas. Requisita-se, a seguir, que descreva, brevemente, o problema-chave que desencadeou a situação mais recente. O objetivo é depreender o contexto em que os usuários do IFUSP utilizam a rede eletrônica para sanar necessidades de informação.

\section{Item 3.2 - Eventos da situação / Estratégias}

Referem-se a diversas etapas da situação, isto é, ás variadas atitudes que o usuário empreendeu na tentativa de solucionar o problema especifico. Essa descrição mais pormenorizada favorece ao pesquisador a compreensão da situação vivenciada pelo usuário como um todo, bem como já delineia as estratégias desenvolvidas para a busca de soluções. São dados que fornecem o ferramental para se avaliar a percep9ão que o usuário tem quanto às características situacionais espaciais de seu problema.

\section{Item 3.3- Lacunas.}

Pede-se ao usuário que apresente, em forma de pergunta, a mais significativa dúvida (receio/anseio/ expectativa) que the sucedeu durante o decorrer da situação. As questões colocadas pelos informantes são os dados primordiais de análise dos itens restantes do instrumento de coleta de dados, bem como da 
própria pesquisa. Os demais itens (3.4 a 3.12) referem-se ao estudo, em profundidade, da questão colocada pelo usuário - a evidência das lacunas defrontadas por eles. Operacionaliza-se tal estudo em duas variáveis: informação e uso.

\section{Item 3.4 - Expectativa de uso da informação}

Solicita-se ao usuário que descreva qual era a sua expectativa no momento em que formulou sua questão, ou seja, como esperava que a resposta aquela questão iria auxiliá-lo a transpor sua lacuna. É evidente, portanto, que esses dados possibilitam a avaliação da expectativa de uso da informação.

\section{I tens 3.5 a 3.9 - Análise da resposta obtida pelo usuário}

Analisam-se em profundidade alguns dos atributos da informação já mencionados nesta pesquisa, tais como: questão respondida ou não, como e qual foi essa resposta e, finalmente, se satisfeito ou não com a mesma. Objetivamente falando, daqui sairão às avaliações quanto ao uso efetivamente dado a informação, em decorrência do que foi obtido junto às fontes utilizadas.

\section{Itens 3.10 a 3.11-Esforço dispendido}

Medem respectivamente o esforço empreendido para a obtenção da resposta á questão e como isso foi realizado. Portanto, tenta-se analisar a importância que o problema tem para o usuário e ainda novas estratégias desenvolvidas para obter resposta.

\section{Item 3.12 - Fontes de informação utilizadas}

Objetiva analisar as fontes de informação utilizadas pelos usuários de maneira geral, bem como aquelas que efetivamente forneceram algum apoio a solução do problema.

No Apêndice D se encontra a Matriz "Cogni9ão x Ação" que correlaciona todas as variáveis do estudo com os itens pertinentes no instrumento de coleta de dados.

Vários pre-testes foram realizados visando alcançar certos objetivos: validar a utilidade da idêntica do Time Line para estudos em ambiente de redes eletrônicas; checar a coerência, fluxo e seqüência dos itens estruturados; investigar a adequação da coleta de dados ao propósito deste estudo; detectar problemas ou dificuldades na coleta de dados, tanto na interpretação dos itens do instrumento, como no manuseio dos recursos da rede para preenchimento e devolução do instrumento através da própria rede e, principalmente, validar a neutralidade do instrumento. 
Duas séries diferenciadas de pré-testes foram elaboradas. Na primeira, o instrumento foi enviado e devolvido por correio eletrônico a vários professores, alunos e pesquisadores da USP, selecionados aleatoriamente. Para cada um desses participantes foram solicitadas informações quanto ao tempo gasto para o preenchimento, dificuldade na interpretação e compreensão dos itens do instrumento e problemas técnicos no recebimento e/ou devolução da mensagem, através do correio eletrônico.

A segunda série de pré-testes foi estruturada de modo a se observar in loco o preenchimento dos instrumentos. O grupo de pesquisadores, alunos de graduação, alunos de iniciação cientifica e técnicos do laboratório do Núcleo de Pesquisas em Novas Tecnologias de Comunicação Aplicadas a Educação da USP - "Escola do Futuro" se prontificaram a colaborar. Os instrumentos foram enviados aos participantes, via correio eletrônico, e entrevistas individuais foram acertadas, com o objetivo de acompanhar e observar o preenchimento do instrumento por pessoas de diferentes níveis. Formulários específicos para o acompanhamento dessas entrevistas foram elaborados, de modo a sistematizar o produto dessas observações. Neles, os pontos críticos evidenciados para servir de roteiro foram: tempo de preenchimento, domínio e controle dos recursos do correio eletrônico pelo informante, compreensão quanto aos itens do instrumento, dificuldades e/ou barreiras percebidas pelos informantes quanto a relembrar c/ou repassar suas situações de uso da rede e, por último, comentários e criticas por parte destes.

Como resultado dos pré-testes, alguns ajustes na estrutura do instrumento foram efetuadas, bem como na linguagem e terminologia empregadas. Esses pré-testes mostraram que, em média, de quinze a vinte minutos eram necessários para se completar o instrumento de coleta de dados, o que pareceu ser bastante razoável para uma pesquisa feita por meio do computador. Quanto aos comportamentos para se mapear as necessidades de informação dos indivíduos, temporal e espacialmente, o resultado deu-se conforme o esperado.

Finalmente, após essas séries, o instrumento foi considerado adequado para se coletar os dados frente aos propósitos deste estudo.

\subsubsection{Universo da Pesquisa: Comunidade de Usuários da Rede IFUSP}

Todos os usuários cadastrados no servidor central VAX da rede local do Centro de Informática do Instituto de Física da USP, foram, a principio, considerados pertencentes ao conjunto do universo da pesquisa. Foi fornecida por aquele Centro uma relação composta de 812 endere9os eletrônicos, sendo 688 contas-correntes. Essas incluíam tanto pessoas como departamentos, secretarias e colegiados, identificados basicamente pelo nome da pessoa ou sigla do local, departamento e user name. 
Foi necessário buscar novos dados, de modo a categorizar funcionalmente esses usuários, o que se fez junto as Secretarias de Graduação e de Departamentos do IFUSP. Essa medida, aliada ao contato próximo com os usuários e troca de informações com pessoas-chave dentro da instituição, propiciaram a estratificação que se segue, para os então usuários da rede IFUSP:

- Alunos de graduação:

57

- Alunos de mestrado:

91

- Alunos de doutorado:

- Docentes:

- Pesquisadores em pós-doutorado:

-Técnicos de apoio - ensino e pesquisa

- Secretaria/Colegiados/Diretorias:

- Usuários externos ao IFUSP:

- Gerente e pessoal do CCIFUSP:

- Ex-alunos e Ex-funcionários:

- Elementos não identificados:

Total:

Observe-se que 36 usuários não puderam ser categorizados por falta de informação sobre os mesmos, suscitando a hipótese de que já não pertenciam mais ao Instituto. Podem ser professores visitantes ou pesquisadoras em regime de pós-doutorado, não identificados nos registros do Instituto, uma vez que seus contratos são providenciados diretamente pelos Departamentos.

Analisando-se os demais grupos de usuários, foram considerados como universo da pesquisa apenas as classes que apresentaram características condizentes com o objetivo da pesquisa, estratificadas como:

a) alunos - respeitando-se os diversos níveis acadêmicos, desde graduação até pósgraduação stricto sensu, mestrado e doutorado. É importante relembrar que somente alunos de graduação com bolsa de iniciação científica tem acesso à rede no IFUSP;

b) docentes - subdivididos de acordo com o mais alto titulo acadêmico (Doutor e Livre Docente) e com pós-doutorado;

c) pesquisadores em pós-doutorado - indivíduos portadores do titulo de doutor, desenvolvendo programas de pós-doutorado no IFUSP;

d) funcionários - representantes da categoria de técnicos de apoio ao ensino e "a pesquisa, todos com graduação, alguns vinculados ao Serviço de Biblioteca e Informação, outros a Laboratórios de pesquisa. 
Para os fins propostos nesta pesquisa, portanto, a população compõe-se de 536 usuários. Desse total, 87 aceitaram participar da pesquisa, respondendo o instrumento em tempo hábil e de maneira condizente, constituindo uma amostra com 16\% do universo em apreço. Outras pesquisas, utilizando essa mesma abordagem do Sense-Making, também têm utilizado voluntaries para seus estudos (NILAN et al, 1991; GLUCK, 1992) apresentando resultados de qualidade. Também o tamanho da amostra tem sido freqüentemente baseado em um método sequencial para coletar dados. Isto é, os dados são buscados e analisados ate que nenhuma nova categoria seja encontrada. Nesse método, a redundância das situações e questões apresentadas pela população predizem o tamanho da amostra. Já foi comprovado em estudos anteriores (GLUCK, 1992; NILAN et al, 1990; FLETCHER, 1991; SCHAMBER, 1991), que um grupo de 30 a 40 pessoas e mais do que adequado para se estudar comportamento de busca e uso da informação dentro desta perspectiva do SenseMaking. For outro lado, segundo AERECK e SETTEL (1985), uma amostra aparentemente pequena é perfeitamente aceitável quando a pesquisa: (a) requer do informante um volume relativamente grande de informação e muito esforço (por exemplo, entrevistas em profundidade como o Time Line); (b) focalizar mais nos padrões estabelecidos entre as respostas do que nos itens observados individualmente.

Sendo a intenção deste estudo cobrir um segmento de pessoas representativo da população, de modo a se obter uma variedade de necessidades de informação pertinente a cada extrato, considerou-se suficiente a amostra obtida. Também a distribuição entre as várias classes de usuários, atingiu as expectativas.

\section{TABELA 4.2.5.1}

\section{DISTRIBUIÇÃO E RETORNO DE INSTRUMENTOS DE COLETA DE DADOS $\times$ CLASSES DE USUÁRIOS DA REDE IFUSP}

\begin{tabular}{|c|c|c|c|}
\hline$\underbrace{N^{\circ} \text { INSTRUMENTOS }}$ & Distribuídos & & \\
\hline CLASSE USUÁRIO & & $\mathrm{N}^{\circ}$ & $\%$ \\
\hline ALUNOS & & & \\
\hline Graduaçăo & 057 & 05 & 08.70 \\
\hline Mestrado & 091 & 13 & 14.20 \\
\hline Doutorado & 165. & 25 & 15.10 \\
\hline Sub-total & 313. & 43 & 13.73 \\
\hline DOCENTES & 167 & 27 & 16.10 \\
\hline PESQUISADORES & 026 & 09 & 34.61 \\
\hline FUNCIONÁRIOS & 030 & 08 & 26.60 \\
\hline TOTAL & 536 & 87 & 16.20 \\
\hline
\end{tabular}


Todos os seis departamentos de ensino e pesquisa do Instituto de Física estão representados na amostra, e distribuídos nas várias classes de usuários, conforme pode ser visualizado na próxima tabela.

TABELA 4.2.5.2

DISTRIBUIÇÃO DO NÚMERO DE INSTRUMENTOS DE PESQUISA RESPONDIDO POR DEPARTAMENTO $\times$ CLASSES DE USUÁRIOS DA REDE IFUSP

\begin{tabular}{|c|c|c|c|c|c|c|c|c|c|c|c|}
\hline \multirow{2}{*}{ DEPTOS. USUÁRIOS } & \multicolumn{4}{|c|}{ ALUNO } & \multicolumn{4}{|c|}{ DOCENTE } & \multirow{2}{*}{$\frac{\text { PESQ }}{\text { PD }}$} & \multirow{2}{*}{$\begin{array}{c}\text { FUNC } \\
\text { GR } \\
\end{array}$} & \multirow[t]{2}{*}{ TOTAL } \\
\hline & GR & ME & $\mathrm{DR}$ & ST & DR & PD & LD & ST & & & \\
\hline FEP & 3 & 5 & 5 & 13 & 3 & - & 1 & 4 & 2 & 1 & 20 \\
\hline FEG & 1 & 1 & 3 & 5 & 6 & - & 1 & 7 & 1 & 2 & 15 \\
\hline FMM & - & 4 & 4 & 8 & 2 & - & - & 2 & - & 1 & 11 \\
\hline FMA & 1 & 1 & 5 & 7 & 3 & - & - & 3 & 2 & - & 12 \\
\hline FNC & - & 1 & 5 & 6 & 5 & - & 1 & 6 & 3 & 1 & 16 \\
\hline FAP & - & 1 & 3 & 4 & 3 & 2 & - & 5 & 1 & 1 & 11 \\
\hline BCA. & - & - & - & - & - & - & - & - & - & 2 & 2 \\
\hline Total & 5 & 13 & 25 & 43 & 22 & 2 & 3 & 27 & 9 & 8 & 87 \\
\hline
\end{tabular}

A distribuição dos informantes por sexo mostrou que embora aparentemente tenha sido baixa a incidência de mulheres (18\%), ela equivale a $15 \%$ do número total de representantes do sexo feminino na população estudada (108 mulheres). Essa porcentagem é praticamente a mesma para o número de homens da amostra (71) em relação ao total da população masculina (480). Em relação à faixa etária do grupo em estudo, 53\% estão entre os 20 e 30 anos, sendo a grande maioria representante do alunado. O segundo maior grupo (31\%) corresponde ao de informantes entre 31 e 40 anos, seguindo de $11 \%$ entre 41 e 50 anos e 4,5\% de 51 a 62 anos, sendo esses dois últimos grupos exclusivamente de docentes. 
TABELA 4.2 .5 .3

DADOS DEMOGRÁFICOS DOS INFORMANTES $\mathbf{x}$ CLASSES DE USUÁRIOS DA REDE IFUSP

\begin{tabular}{l|ccc:c|ccc|c|c|c|c|c}
\hline \multirow{2}{*}{ USUÁRIOS } & \multicolumn{3}{|c|}{ ALUNO } & \multicolumn{3}{c|}{ DOCENTE } & PESQ & FUNC & TOTAL \\
\cline { 2 - 11 } & GR & ME & DR & ST & DR & PD & LD & ST & PD & GR & \\
\hline SEXO & & & & & & & & & & & \\
masculino & 4 & 11 & 22 & 37 & 18 & 2 & 2 & 22 & 7 & 5 & 71 \\
feminino & 1 & 2 & 3 & 6 & 4 & - & 1 & 5 & 2 & 3 & 16 \\
\hline \hline \multicolumn{1}{c|}{ TOTAL } & 5 & 13 & 25 & 43 & 22 & 2 & 3 & 27 & 9 & 8 & 87 \\
\hline \hline
\end{tabular}

IDADE (anos)

\begin{tabular}{l|ccc|c|ccc|c|c|c|c}
$20-30$ & 5 & 12 & 19 & 36 & 2 & - & - & 2 & 4 & 4 & 46 \\
$31-40$ & - & 1 & 6 & 7 & 11 & 2 & - & 13 & 5 & 3 & 28 \\
$41-50$ & - & - & - & - & 5 & - & 3 & 8 & - & 1 & 10 \\
$51-62$ & - & - & - & - & 4 & - & - & 4 & - & - & 4 \\
\hline \hline TOTAL & 5 & 13 & 25 & 43 & 22 & 2 & 3 & 27 & 9 & 8 & 87 \\
\hline \hline
\end{tabular}

Uma análise quanto ao grau acadêmico de mais alto nível revelou que 3 informantes possuem o título de Livre-Docente, 2 já terminaram o pós-doutorado, 31 são Doutores, 22 Mestres, 21 concluíram a graduação e 8 a estão cursando. Dentre esses, 34,48\% receberam esses títulos entre 1991 e 1994; 23\% na década de 80 e 8\% anterior a 1980. Outra análise mostra ainda que $50 \%$ desses títulos foram obtidos no próprio Instituto de Física da USP; $6 \%$ em outras unidades da USP; $12 \%$ em outras universidades brasileiras e apenas 7\% no exterior; e o restante, 25\%, não indicam o local. Esse grande contingente de elementos, que obteve grau e titulação no próprio IFUSP, pode significar que a maioria do grupo em estudo está condicionada as formas de ensino, treinamento e pesquisa da própria instituição, sendo que os demais podem ou não ter trazido hábitos diferenciados, principalmente os que estudaram no exterior, onde as RE estão muito mais avançadas e há muito mais tempo em funcionamento. 
TABELA 4.2.5.4

DISTRIBUIÇÃO DOS INFORMANTES POR

GRAU ACADÊMICO, ANO E LOCAL DE FORMAÇÃO

\begin{tabular}{l|c|c|c|c|c|c}
\hline \multirow{2}{*}{ UATEGORIAS } & \multicolumn{5}{|c|}{ GRAU ACADÊMICO } & \multirow{2}{*}{ TOTAL } \\
\cline { 2 - 6 } ANO DE FORMAÇÄO & GR & ME & DR & PD & LD & \\
61-70 & & & & & & \\
$71-80$ & - & - & 2 & - & - & 2 \\
$81-90$ & - & - & 4 & - & 1 & 5 \\
$91-94$ & 8 & 4 & 14 & - & - & 26 \\
Graduação em decurso & 11 & 4 & 11 & 2 & 2 & 30 \\
S/R & 8 & - & - & - & - & 8 \\
\hline \hline TOTAL & 2 & 14 & - & - & - & 16 \\
\hline \hline
\end{tabular}

LOCAL DE FORMAÇÃO

BRASIL

USP/Instituto de Física

USP/Outras unidades

Outras univers. brasileiras

EXTERIOR

América do Norte

Europa

$S / R$

\begin{tabular}{|l|c|c|c|c|c}
$16^{*}$ & 6 & 19 & - & 3 & 44 \\
4 & - & 1 & - & - & 5 \\
2 & 2 & 6 & - & - & 10 \\
& & & & & \\
- & - & 4 & 1 & - & 5 \\
- & - & 1 & - & - & 1 \\
7 & 14 & - & 1 & - & 22 \\
\hline 29 & 22 & 31 & 2 & 3 & 87 \\
\hline
\end{tabular}

*Inclue os informantes que estāo cursando a graduaçăo 


\subsubsection{Descrição da Análise dos Dados}

A pesquisa de campo foi conduzida de modo a produzir dados que permitissem criar e, posteriormente, generalizar indutivamente padrões dinâmicos da busca de informação mantida pelo grupo estudado de usuários da rede local do IFUSP.

Os dados coletados foram analisados em dois estágios. O primeiro refere-se à análise de conteúdo e o segundo, ao tratamento estatístico.

$\mathrm{Na}$ análise de conteúdo, elaboraram-se esquemas específicos para cada uma das variáveis abertas deste estudo, que são: identificação dos usuários; propósitos de uso de redes; barreiras e dificuldades no uso da rede e no acesso à informação; tópicos ou contexto das situações gerais que levaram os usuários a utilizar a rede; descrição das necessidades de informação; fontes de informação utilizadas; estratégias desenvolvidas; uso esperado e recebido com as respostas as questões dos usuários. Dada a relevância e o nível de detalhamento desenvolvido para essa análise, faz-se imprescindível aprofundar o tema ainda neste capítulo.

Para a análise estatística, utilizando o software Excel, foram elaboradas várias tabelas com a descrição dos resultados. Os dados foram organizados em função das classes de usuários e computada as freqüências de ocorrência das variáveis estabelecidas na análise de conteúdo.

\subsubsection{Análise de Conteúdo (AC)}

Analisando e compilando definições de vários autores, depreendeu-se que análise de conteúdo pode ser utilizada para:

- descrever sistematicamente a forma e o conteúdo de materiais escritos ou falados (SOMMER e SOMMER,1986);

- estudar e analisar comunicações de uma maneira sistemática, objetiva e quantitativa através da avaliação de diferentes variáveis (KERLINGER, 1986, p.479);

- filtrar dados, permitindo que o produto de uma comunicação (escrito, verbal, digital, visual e outros) seja transformado em um formato apropriado a subseqüentes análises (AGARWAL, 1988, p.68).

Desde que foi desenvolvida, a AC vem sendo cada vez mais aplicada a pesquisas que necessitam codificar questões abertas e descrever tendências em contextos de comunicação. Seu uso tem sido também bastante diferenciado, dependendo do propósito da análise e da natureza das questões de pesquisas específicas que estão sendo trabalhadas. (AGARWAL, 1988, p.69). 
A idéia central, refletida nas várias definições existentes, e o processo de transformação onde grandes volumes de material textual são classificados em umas poucas categorias, de acordo com seus conteúdos (WEBER, 1985). Assim, palavras ou frases classificadas dentro de uma mesma categoria possuem presumível mente a mesma qualidade e, aqui, a definição de qualidade recai na função dos objetivos da pesquisa.

Essa categorização permite fazer inferências sobre formas e conteúdos de comunicação. Portanto, seu propósito é usar a categorização do texto para gerar variáveis que enderecem adequadamente as questões substantivas dos pesquisadores.

O ponto crítico na análise de conteúdo o desenvolvimento de esquemas analíticos validos e confiáveis. WEBER (1986) relaciona uma serie de passes imprescindíveis para se atingir tal objetivo (apud GLUCK, 1992). Tais passes, descritos abaixo, foram rigorosamente seguidos nesta pesquisa:

1 $^{\circ}$ PASSO - E a determinação da unidade de registro que melhor se encaixa as necessidades do estudo. Essas unidades podem ser palavras, o sentido das palavras, sentenças, tópicos, parágrafo e/ou o texto completo. Para se identificar uma unidade de registro, algumas regras são necessárias de modo a manter consistência na codificação e na classificação.

Neste estudo, vários tipos de unidades de análise foram eleitos. Para a interpretação dos conhecimentos e usos dos recursos e serviços das redes (parte 2 do instrumento de coleta de dados), a unidade de análise refere-se a tópicos específicos derivados das respostas qualitativas fornecidas nos diferentes itens. Na ultima parte do instrumento, as unidades de análise revestem-se em frases e contextos situacionais específicos do comportamento de busca e uso da informação por parte dos usuários da rede do IFUSP. A unidade de análise principal as questões, representativas das necessidades de informação/lacunas apresentadas pelos próprios usuários.

$2^{\circ}$ PASSO - Após definida a unidade de análise, desenvolvem-se as categorias que serão utilizadas para a classificação do material. Segundo AGARWAL (1988), essas categorias podem ser feitas de forma indutiva ou dedutiva. Categorias desenvolvidas indutivamente são as geradas a partir de aproximadamente $20 \%$ dos dados coletados e onde cada variável de interesse identificada por vez. Esquemas indutivos são essencialmente abertos, ou seja, cada nova unidade de análise e inserida, ou nas

\footnotetext{
${ }^{9}$ Categorizar, segundo PIOVESAN (1979, p. 15), significa dispor, distribuir por categorias. E categorias define como "cada uma das classes em que se dividem as idéias, ou os termos", ou "subdivisão de uma variável usada na classificação dos dados". Geralmente, o termo e limitado as subdivisões de uma variável qualitativa, embora, algumas vezes seja também usado para se referir aos intervalos de classe de uma variável quantitativa".
} 
categorias já previamente definidas, ou nova categoria e criada. Categorias dedutivas são as predefinidas pelo pesquisador como de interesse prioritário para a análise dos dados.

Neste estudo, foram utilizadas ambas as categorias:

a) indutivas- por exemplo aquelas elaboradas para análise das variáveis, propósitos, barreiras, dificuldades e treinamento para o uso das redes, situações que levam os usuários a rede, descrição da questão, fontes de informação, estratégias (ver Apêndice B)

b) dedutivas - algumas preestabelecidas pela pesquisadora, como por exemplo, as utilizadas para classificação dos dados na parte 1 do instrumento que trata da identificação dos usuários (Apêndice B). E outras estabelecidas por Brenda Dervin, adaptadas para este estudo, por medirem as mesmas variáveis propostas, já tendo sido testadas em outros estudos, provando sua eficiência. Exemplos dessas categorias são encontrados nos esquemas para análise da expectativa de uso da informação, da natureza e do foco da questão do usuário (Apêndice B).

Os esquemas indutivos partiram das informações obtidas nos diversos itens abertos do instrumento de coleta de dados ${ }^{10}$. Ou seja, as respostas dos informantes foram agrupadas e analisadas uma a uma em função das diversas variáveis deste estudo. Para cada uma dessas variáveis foram elaborados esquemas de análise de conteúdos específicos, com descrição das categorias pertinentes, critérios de classificação, instruções e código para tabulação.

Para se chegar à determinação das categorias específicas em cada análise de conteúdo desenvolvida, observaram-se quatro princípios básicos prescritos por PIOVESAN(1977, p. 17):

- homogeneidade: todas as categorias devem ser da mesma natureza e se referirem a característica da variável;

- inclusividade (ou exaustividade): sempre deve haver uma categoria para se computar qualquer elemento de determinado universo ou amostra, portador da característica correspondente a variável;

- utilidade: as categorias devem apresentar uma freqüência significativa quanto à magnitude (nem muito alta, nem muito baixa) e a capacidade discriminatória (diferenças significativas nas categorias de variável dependente);

- mutua exclusividade: cada ser de determinado universo só pode ser computado em uma e apenas uma categoria.

${ }^{10}$ A escala padrão binário (resposta do tipo "sim/não") foi utilizada para análise de algumas variáveis em questões fechadas. 
$3^{\circ}$ PASSO - Concluída a identificação e definição das categorias a serem utilizadas, foi necessário proceder a uma revisão dos esquemas, de modo a eliminar ambigüidades e garantir a objetividade dos mesmos. Isto pode ser feito utilizando diferentes grupos de. dados, diferentes codificadores, procedimentos padronizados ou procurando-se um coeficiente de segurança para cada esquema elaborado de análise. Especificamente, neste estudo, a pesquisadora contou com a colaboração de dois especialistas (um estatístico e outro antropólogo) para a tarefa de codificação e validação das categorias no total de dados. Após vários dias de discussão em conjunto, chegou-se a um consenso geral quanto às categorizações adequadas, com alto grau de concordância.

$4^{\circ}$ PASSO - Concluída a validação dos esquemas de análise de conteúdos para cada uma das variáveis deste estudo, inicia-se a fase de classificação, codificação, e tabulação dos dados coletados. Finalmente, procede-se a análise quantitativa dos dados e suas devidas interpretações.

Embora a técnica de análise de conteúdo consista numa atividade muito minuciosa (SOMMER e SOMMER, 1986), que consome muito tempo (GLUCK, 1992) e energia do pesquisador, e, de maneira comprovada bastante conveniente para estudos comparativos entre populações, grupos ou nações diferentes (NILAN, 1987; PANNEN, (1991; SCHAMBER, 1991; GLUCK, 1992).

Os esquemas para as análises de conteúdo (AC) que emergiram dos dados coletados estão relacionados a seguir. De modo a não sobrecarregar este capítulo, tais esquemas foram incluídos no Apêndice $B$, onde podem ser observados em sua plenitude.

\section{Esquemas para Análise de Conteúdo - AC}

\section{AC 01 - DADOS DE IDENTIFICACÃO DOS USUÁRIOS}

AC OV1 - Departamento e Laboratório do IFUSP

AC 01/2 - Posição / Vínculo dos usuários com o IFUSP

AC 01/3 - Idade dos usuários

AC 01/4 - Sexo

AC 01/5 - Formação acadêmica de mais alto nível.

AC 01/6 - Data da Formação de mais alto nível

AC 01/7 - Local da Formação de mais alto nível

\section{AC 02 - CONHECIMENTO E USO DA REDE ELETRÔNICA}

AC 02/1 - Experiência com computadores

AC 02/2 - Expenência com as redes DECNET, BITNET e INTERNET 
AC 02/3 - Periodicidade no uso de serviços e/ou aplicativos das RE AC 02/4 - Propósitos no uso das redes

AC 02/5 - Participação em Listas de Discussão

AC 02/6 - Barreiras no uso das RE

AC 02/7 - Dificuldades no Acesso à informação

AC 02/8 - Treinamento formal

\section{AC 03 a 11 - SITUACÃO RECENTE DE USO DA REDE}

AC 03 - Tópico da Situação

AC 04 - Natureza da questão do usuário à 5W

AC 05 - Foco da questão do usuário

AC 06 - Expectativa de uso da informação a ser recebida

AC 07 - Estratégias empreendidas pelo usuário

AC 08/1 - Completeza da resposta obtida pelo usuário

AC 08/2 - Satisfação com a resposta obtida pelo usuário

AC 08/3 - Esforço dispendido para obtenção da resposta

AC 09 - Critérios para avaliação da completeza da resposta e satisfação pessoal

AC 10 - Fontes de informação

AC 11 - Recursos informacionais utilizados

As leituras e análises dos dados coletados estão apresentadas no próximo capítulo. 


\section{CAPÍTULO 5}

\section{ANÁLISE DOS RESULTADOS \\ DA \\ PESQUISA DE CAMPO}

Análises quanto Ao conhecimento e uso das redes eletrônicas, busca e uso da informação nas redes eletrônicas e necessidades de informação não solucionadas. 


\section{PRELIMINARES}

O objeto desta pesquisa foi evidenciar o comportamento de busca e uso da informação junto aos usuários de uma das redes de comunicação eletrônica melhor sedimentada da Universidade de São Paulo, qual seja a do Instituto de Física.

Este capítulo apresenta a descrição e interpretação geral dos resultados obtidos junto à população como um todo, com algumas análises por classes de usuários, quando pertinente.

As tabelas estão colocadas logo após a descrição e análise do item correspondente; sua numeração e respectivos cabeçalhos correspondem aos títulos dos capítulos, seguidos de devidas complementações. Foram elaboradas em função das 4 classes de usuários integrantes do estudo e seus respectivos graus acadêmicos, a saber:

a) classe dos alunos - graduandos (GR), mestrandos (ME) e doutorandos (DR);

b) classe dos docentes - doutores (DR), pós-doutores, (PD) e livre-docentes (LD);

c) classe dos pesquisadores - elementos em pós-doutoramento (PD);

d) classe dos funcionários - todos com nível de graduação (GR)1.

Optou-se por apresentar, nas tabelas, as freqüências ${ }^{2}$ detectadas no cruzamento das classes de usuários com as categorias das variáveis. Isso permitiu maior maleabilidade na análise dos dados a qual, descrita em porcentagem, ora descreve a população como um todo, ora classes de usuários em particular.

Como já mencionado no capítulo anterior, os esquemas elaborados para as várias análises de conteúdos foram colocados no Apêndice B visando não sobrecarregar o texto. Sempre que necessário, estão incluídas explicações mais detalhadas sobre as categorias determinadas para análise, com indicação do local exato onde pode ser encontrado o esquema correspondente.

Finalmente, quanto aos resultados, vale relembrar que em três pontos principais recaiu a preocupação desta pesquisa:

a) detectar algumas características demográficas dos informantes (já incluídas no capítulo anterior, item 4.2.5 - na descrição da população em estudo);

b) identificar o conhecimento e uso dos recursos e serviços da RE;

c) evidenciar percepção, compreensão, habilidades físicas e cognitivas quando da busca de soluções para problemas de informação através das redes eletrônicas.

\footnotetext{
${ }^{1}$ Referente ao corpo discente e docente foi incluída, nas tabelas, uma coluna do subtotal (ST) com a somatória do número global dessas classes por categoria analisada.

2 Freqüência: "número de vezes que um valor ou um subconjunto de valores do domínio de uma variável aleatória aparece numa experiência ou numa observação de caráter estatístico" (FERREIRA, p. 655)
} 
Frente a essas preocupações, os resultados foram trabalhados em três análises distintas, a saber:

\section{ANÁLISE I \\ CONHECIMENTO E USO DAS REDES ELETRÔNICAS}

A análise e interpretação de seis variáveis integrantes desta parte do estudo mostra o que representa para os informantes, em tese, o uso das RE, quais suas finalidades e funções, dificuldades e barreiras, conhecimento e interesse. Várias tabelas foram elaboradas visando facilitar a compreensão do conjunto de resultados, e apresentar os graus de conhecimento e uso das redes eletrônicas.

Nesta análise, todos os instrumentos de coleta de dados retomados foram incluídos, totalizando portanto 87 informantes.

\section{ANÁLISE II BUSCA E USO DA INFORMAÇÃO VIA REDE ELETRÔNICA}

Esta análise revela o que, na realidade, está ocorrendo nas interfaces dos informantes com as redes eletrônicas de comunicação, como tem sido experimentado e vivenciado o processo de busca e uso da informação através das RE.

Sob a égide das três grandes pontas do modelo do Sense Making: situação-lacunauso, dez variáveis são investigadas, analisadas, interpretadas e ilustradas, num conjunto de 17 tabelas. Os resultados mostram os diferentes tipos de comportamento de busca e uso da informação, detectados junto sas várias classes de usuários da rede IFUSP.

Esta Análise trabalha com o total de 61 informantes, ou seja, aqueles que forneceram dados completos e suficientes.

Justifica-se esse número o fato de que 26 dos informantes não se sentiram em condições de preencher a parte 3 do instrumento de coleta de dados, referente ao uso recente das RE para solucionar problemas, resolver dificuldades ou localizar respostas a perguntas. Dentre os motivos alegados, dois disseram não ter entendido o que estava sendo solicitado (e mesmo após algumas trocas de mensagens explicativas, ainda não se sentiram seguros em completar os dados). Outros 16 informantes mencionaram nunca terem utilizado a rede nas condições propostas, justificando que não são "grandes" usuários da rede e apenas recorrem a ela para executar programas ou aplicativos, cálculos estatísticos, transferir resultados de um computador a outro e ainda correio eletrônico. Outros três simplesmente disseram nunca tê-la usado, sem maiores detalhes; três 
deixaram o espaço em branco, e duas respostas foram anuladas devido à incoerência nas informações prestadas.

\section{ANÁLISE III NECESSIDADES DE INFORMAÇÃO NÃO SOLUCIONADAS}

Cinco tabelas adicionais analisam, separadamente, todas as situações em que os usuários não obtiveram respostas as suas questões. Portanto, não alcançaram as informações necessárias para transpor suas lacunas.

Seguindo o mesmo padrão da Análise II, e averiguada a incidência de questões não respondidas em função dos contextos que vem levando os usuários as RE, da natureza e foco dessas questões, do uso esperado da resposta, das estratégias desenvolvidas e do esforço empreendido. A revisão desses, aparentemente, "insucessos" pode detectar pontos importantes a serem considerados na identificação dos padrões de comportamento desses usuários.

A análise III e apresentada com o total de 22 informantes, ou seja, aqueles que não conseguiram satisfazer suas necessidades de informação.

A seguir se encontram detalhadas as três análises descritas acima. 


\section{ANÁLISE I}

\subsection{CONHECIMENTO E USO DAS REDES ELETRÔNICAS}

\subsubsection{Experiência com Computadores}

(cf. Tabela 5.1.1.1, AC\#02/1 - Apêndice B)

Classificando a população em função do tempo de uso de computadores, verifica-se que $68 \%$ dos informantes utilizam-no há mais de 5 anos, sendo que desses, $46 \%$ ha mais de 10 anos.

Saber que esses informantes possuem tal experiência e provavelmente domínio, familiaridade, controle e conhecimento básico desse equipamento, bem como de seus inúmeros derivados, leva-nos a inferir que devam estar preparados tecnicamente para usufruir das vantagens oferecidas pelas redes

eletrônicas

TABELA 5.1.1.1

TEMPO DE EXPERIENCIA COM COMPUTADORES $X$ CLASSES DE USUÁRIOS DA REDE IFUSP

\begin{tabular}{|c|c|c|c|c|c|c|c|c|c|c|c|}
\hline \multirow{2}{*}{ CATEGORIAS USUÁRIOS } & \multicolumn{4}{|c|}{ ALUNO } & \multicolumn{4}{|c|}{ DOCENTE } & \multirow{2}{*}{$\frac{\text { PESQ. }}{\text { PD }}$} & \multirow{2}{*}{$\frac{\text { FUNC. }}{\text { GR }}$} & \multirow[t]{2}{*}{ TOTAL } \\
\hline & GR & ME & DR & ST & DR & PD & LD & ST & & & \\
\hline \multicolumn{12}{|l|}{$N^{\circ}$ DE ANOS } \\
\hline $00 \nrightarrow 01$ & - & - & 1 & 1 & - & - & - & - & - & - & 1 \\
\hline $01-03$ & 1 & 1 & 1 & 3 & 1 & - & - & 1 & - & 1 & 5 \\
\hline $03-05$ & 2 & 6 & 6 & 14 & 3 & - & - & 3 & 2 & 1 & 20 \\
\hline $05-10$ & 2 & 4 & 15 & 21 & 5 & - & - & 5 & 4 & 5 & 35 \\
\hline$>10$ & - & 1 & 2 & 3 & 13 & 2 & 3 & 18 & 3 & - & 24 \\
\hline$S / R$ & - & 1 & - & 1 & - & - & - & - & - & 1 & 2 \\
\hline TOTAL & 5 & 13 & 25 & 43 & 22 & 2 & 3 & 27 & 9 & 8 & 87 \\
\hline
\end{tabular}

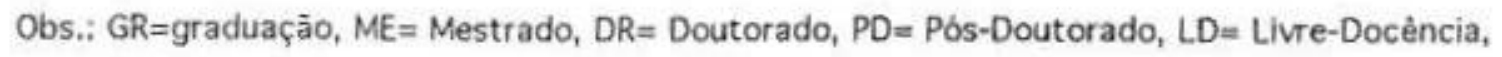
$\mathrm{ST}=$ Sub-Total 


\subsubsection{Experiência com a DECNET, BITNET e INTERNET}

(cf. Tabela 5.1.2.1, AC \#02/2 - Apêndice B)

Evidenciar o tempo de experiência dos informantes em relacjio ao uso das três redes disponíveis no IFUSP pode elucidar os motivos de haver certas dificuldades na busca e uso da informação.

Como a rede local do IFUSP se conectou a BITNET, via DECNET, em agosto de 1989, e a INTERNET, em princípio de 1992, estima-se que há anos seja o tempo máximo que essa comunidade esteja participando da comunicação eletrônica internacional.

Constata-se que 15\% dos informantes utilizam a DECNet e BITNET e 29\% a INTERNET, desde seu início. Entretanto, um quarto dos usuários da DECNet e da BITNET e metade dos usuários da INTERNET mencionam que as usam a mais tempo do que elas estão disponíveis no país. Isto nos leva a levantar duas hipóteses:

$1^{\text {a) }}$ esses usuários talvez tenham tido acesso a rede no exterior em alguma situação de estudo ou viagem. Estranha-se o fato porque apenas 7\% dos informantes concluíram recentemente titulação no exterior. Parece, portanto, não ser essa a explicação;

$2^{\mathrm{a}}$ ) talvez alguns usuários não conheçam as diferenças e peculiaridades de cada rede. $\mathrm{Na}$ realidade, isso foi textualmente mencionado por vários mestrandos e doutorandos. $E$ bastante comum, ainda hoje, o uso da expressão "enviar um BITNET" quando se quer significar "enviar uma mensagem pelo email". Isto causa ruídos e concepções errôneas. Percebe-se de modo claro desconhecimento das características de cada rede em várias das respostas obtidas.

A rede menos utilizada, principalmente entre o alunado, 6 a DECNET, naturalmente por ser mais restrita do que as outras. A mais conhecida e utilizada 6 a Internet. Quanto a BITNET, percebe-se que há pouca utilização apenas entre o alunado (35\%) e os funcionários (37,5\%). A classe de usuários que, de maneira geral, há mais tempo vem usufruindo dos benefícios das três redes é o pesquisador. 
TABELA 5.1.2.1

TEMPO DE EXPERIENNCIA NO USO DE REDES ELETRÕNICAS $x$ CLASSES DE USUÁRIOS DA REDE IFUSP

\begin{tabular}{|c|c|c|c|c|c|c|c|c|c|c|c|}
\hline \multirow{2}{*}{ CATEGORIAS USUÁRIOS } & \multicolumn{4}{|c|}{ ALUNO } & \multicolumn{4}{|c|}{ DOCENTE } & \multirow{2}{*}{$\frac{\text { PESQ. }}{\text { PD }}$} & \multirow{2}{*}{\begin{tabular}{|c|} 
FUNC. \\
GR \\
\end{tabular}} & \multirow[t]{2}{*}{ TOTAL } \\
\hline & GR & ME & DR & ST & DR & PD & LD & ST & & & \\
\hline \multicolumn{12}{|l|}{ DECNET* } \\
\hline Nunca & 3 & 7 & 11 & 21 & 6 & 2 & 1 & 9 & - & 4 & 34 \\
\hline $00-01$ & - & 1 & 2 & 3 & 1 & - & - & 1 & - & 1 & 5 \\
\hline $01 \dashv 03$ & 1 & 1 & 4 & 6 & 4 & - & - & 4 & 1 & 2 & 13 \\
\hline $03 \multimap 05$ & 1 & 2 & 4 & 7 & 3 & - & - & 3 & 3 & - & 13 \\
\hline$>05$ & - & 1 & 4 & 5 & 8 & - & 2 & 10 & 5 & - & 20 \\
\hline$S / R$ & - & 1 & - & 1 & - & - & - & - & - & 1 & 2 \\
\hline TOTAL & 5 & 13 & 25 & 43 & 22 & 2 & 3 & 27 & 9 & 8 & 87 \\
\hline
\end{tabular}

BITNET *

\begin{tabular}{l|ccc|c|ccc:c|c|c|c} 
Nunca & 3 & 5 & 7 & 15 & 1 & - & - & 1 & - & 3 & 19 \\
$00 \rightarrow 01$ & 1 & 2 & 2 & 5 & 1 & 1 & - & 2 & - & 1 & 8 \\
$01 \rightarrow 03$ & 1 & 4 & 6 & 11 & 4 & - & - & 4 & 1 & 1 & 17 \\
$03 \rightarrow 05$ & - & 1 & 6 & 7 & 6 & - & 2 & 8 & 5 & 2 & 22 \\
$>05$ & - & 1 & 4 & 5 & 10 & 1 & 1 & 12 & 3 & - & 20 \\
S/R & - & - & - & - & - & - & - & - & - & 1 & 1 \\
\hline \hline \multicolumn{1}{r|}{ TOTAL } & 5 & 13 & 25 & 43 & 22 & 2 & 3 & 27 & 9 & 8 & 87 \\
\hline \hline
\end{tabular}

INTERNET *

Nunca

$00 \multimap 01$

$01 \multimap 03$

$03 \rightarrow 05$

$>05$

$\mathrm{S} / \mathrm{R}$

TOTAL

\begin{tabular}{|ccc:c|ccc:c|c|c|c}
- & 1 & 2 & 3 & 3 & - & - & 3 & - & - & 6 \\
2 & - & 3 & 5 & 2 & - & - & 2 & - & 3 & 10 \\
2 & 7 & 7 & 16 & 6 & - & - & 6 & 2 & 1 & 25 \\
1 & 3 & 10 & 14 & 6 & 2 & 2 & 10 & 4 & 3 & 31 \\
- & - & 3 & 3 & 5 & - & 1 & 6 & 3 & - & 12 \\
- & 2 & - & 2 & - & - & - & - & - & 1 & 3 \\
\hline 5 & 13 & 25 & 43 & 22 & 2 & 3 & 27 & 9 & 8 & 87 \\
\hline
\end{tabular}

* Número de anos 


\section{5.1.3 Conhecimento e Uso dos Recursos das RE}

(cf. Tabela 5.1.3.13, AC \#02/3 - Apêndice B)

Uma lista - com nomes e siglas dos principais recursos e serviços disponíveis nas RE foi elaborada e submetida aos informantes para que indicassem:

a) os que não conhecem e portanto nunca usam;

b) aqueles que conhecem, mas nunca utilizaram;

c) quais conhecem e utilizam de acordo com as frequências: "de vez em quando", "várias vezes por mês", "várias vezes por semana" ou "diariamente" 4.

Iniciando pela observação da tríade referente aos serviços básicos da Internet (correio eletrônico, FTP e Telnet), alguns dados importantes foram identificados. Obviamente todos conhecem e utilizam o correio eletrônico, uma vez que os instrumentos de pesquisa foram enviados aos informantes e devolvidos por eles como mensagem eletrônica. Mesmo assim, um funcionário menciona que não conhece o email e outro diz que nunca o utiliza. Pode significar um equivoco, na hora do preenchimento do instrumento, ou até mesmo um real desconhecimento dos termos, pois ambos são usuários iniciados há pouco tempo. Fica evidente o uso diário do correio eletrônico por

$62 \%$ dos informantes, cnquanto $17 \%$ o utilizam várias vezes por semana

De modo global, pode-se mencionar que $86 \%$ dos informantes já utilizam o FTP e $87 \%$ o Telnet, demonstrando com isso que esses serviços vêm, de alguma maneira, fornecendo auxílio no desenvolvimento das pesquisas de uma porcentagem considerável de informantes. A transferência de arquivo por FTP também tem sido uma atividade diária para $16 \%$ dos indivíduos, enquanto $29 \%$ o utilizam várias vezes por semana. No entanto, $14 \%$ nunca o utilizam. Conectar-sc remotamente a outros computadores via Telnet e mencionado por $26 \%$ dos informantes como uma atividade diária e para 17\% como sendo utilizada várias vezes por semana. Porém, 13\% nunca utilizam esse serviço, sendo que desses mais da metade nem o conhecem.

\footnotetext{
3 Tabela-síntese de todos os serviços e aplicativos estudados. Tabelas específicas para cada um deles são incluídas no Apêndice $C$, de modo a não sobrecarregar o texto.

${ }^{4}$ Essas freqüências estão incluídas somente na tabela "Uso dos recursos e serviços disponíveis nas redes eletrônicas" do Apêndice C.
} 


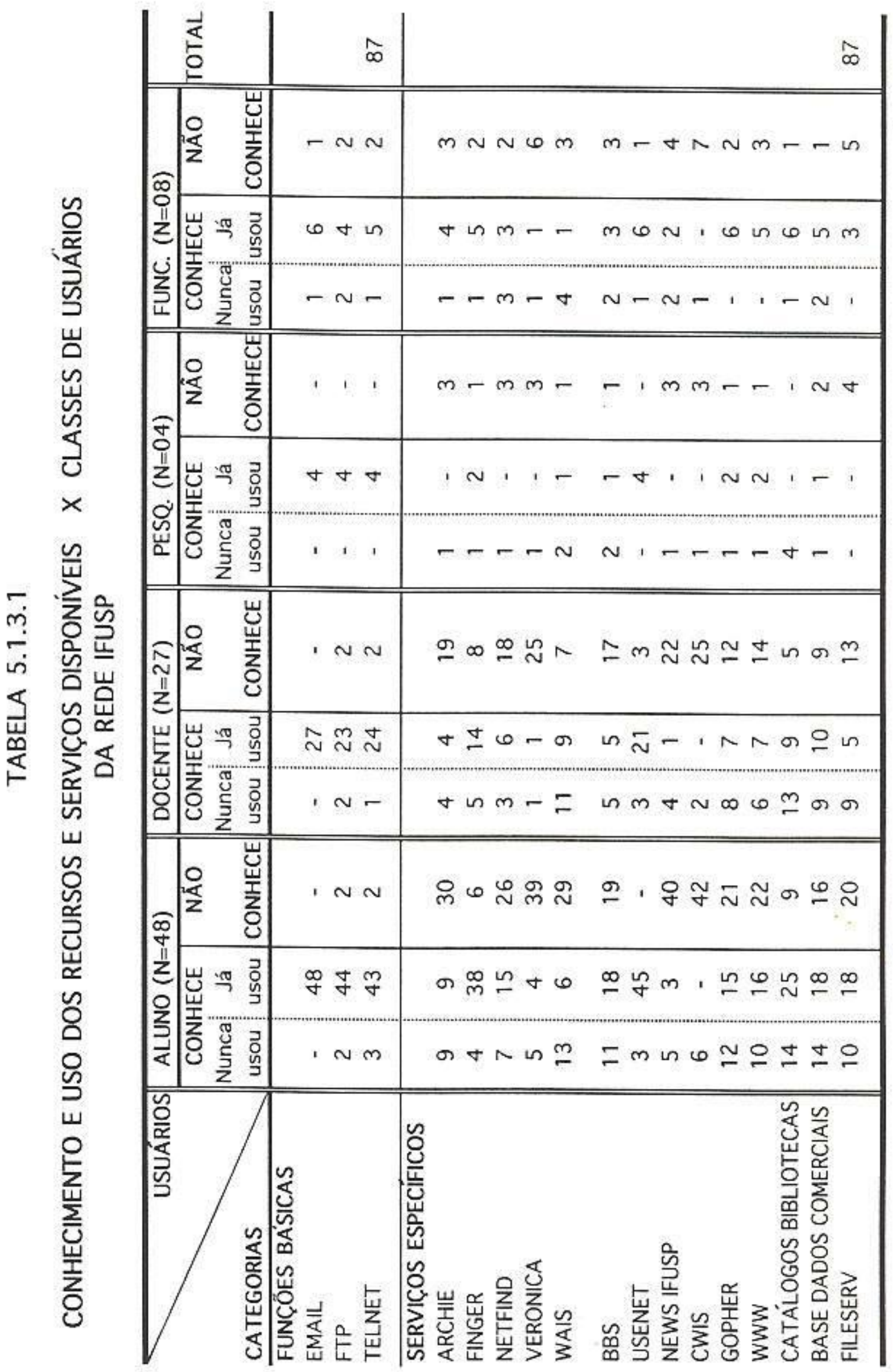


O importante deste item foi à análise dos demais recursos e serviços disponíveis nas redes, em que se percebe os seguintes resultados gerais:

$\begin{array}{ll}\text { DESCONHECIDO } & \text { NUNCA UTILIZADO } \\ 63 \% & 80 \% \\ 56 \% & 72 \% \\ 83 \% & 93 \% \\ 45 \% & 80 \% \\ 46 \% & 69 \% \\ 80 \% & 93 \% \\ 88 \% & 100 \% \\ 41 \% & 66 \% \\ 46 \% & 66 \% \\ 17 \% & 54 \% \\ 32 \% & 61 \% \\ 20 \% & 32 \% \\ 4 \% & 12 \%\end{array}$
a) ARCHIE-
b) NETFIND -
c) VERONICA -
d) WAIS -
e) BBS -
f) NEWS da Física -
g) CWIS -
h) Gopher -
$12 \%$

$\begin{array}{lll}\text { i) WWW - } & 46 \% & 66 \% \\ \text { j) Catálogos de bibliotecas - } & 17 \% & 54 \% \\ \text { k) Bases Dados Comerciais - } & 32 \% & 61 \% \\ \text { I) FINGER - } & 20 \% & 32 \% \\ \text { m) USENET - } & 4 \% & 12 \%\end{array}$

Frente a esses resultados, pode-se afirmar com certeza que os três básicos são os mais conhecidos, sendo o correio eletrônico o mais utilizado deles. Fora isso, o FINGER e o USENET são conhecidos e manuseados. O primeiro está relacionado exclusivamente à busca de endereços individuais e pessoais, enquanto o segundo refere-se $\mathrm{i}$ troca de informações entre pessoas de interesse comum. Metade dos informantes utiliza o USENET várias vezes por semana. Dentre os demais servidores, o Gopher e o WWW são os que apresentam melhor desempenho.

Julgou-se, inicialmente, que a experiência com computadores e o número de anos de conexão as RE poderiam ser indicativos do nível de conhecimento e uso dos serviços e aplicativos disponíveis, dado que a divulgação deles sempre e bastante intensa no próprio ambiente eletrônico. Porém neste estudo tal suposi9ão não foi observada. Esta evidente que a maioria dos informantes conhece muito pouco os serviços de recuperação de informação disponíveis.

A maior surpresa, porém"m, foi detectar que 80\% dos informantes desconhecem 0 Servidor NEWS do VAX, e 93\% nunca o utilizam. Conforme já foi mencionado, ele e apresentado aos usuários sempre que uma seção e aberta. Sabendo que 80\% dos informantes utilizam o correio eletrônico várias vezes por semana, presume-se que:

\footnotetext{
${ }^{5}$ Engloba o total de usuários que nunca ouviram falar no serviço ou recurso em questão, e aqueles que já ouviram falar, mas nunca o utilizaram.
} 
$\left(1^{\circ}\right)$ esses informantes não fizeram correlação entre tal nome - News do IFUSP - e o que Ihes e sistematicamente apresentado, ou

$\left(2^{\circ}\right)$ eles realmente desconhecem o que seja o serviço e, portanto, não lêem as chamadas iniciais apresentadas em seus mailbox.

Relembrando os serviços especificamente elaborados para a comunidade acadêmica pela CIA-Info e pela Biblioteca, e divulgados através do NEWS (descrito no capítulo 4), e realmente significativo tal resultado. Pode estar ocorrendo que o CCIFUSP ao utilizar, única e exclusivamente, a própria rede para divulgar seus serviços, não vem atingindo os usuários reais e potenciais.

Assim, quer por desconhecimento, quer por falhas na divulgação, quer por mau uso dos serviços disponíveis, a comunidade acadêmica parece estar subutilizando o sistema. Esse contexto em ambiente eletrônico reflete o mesmo comportamento observado por FAIBISOFF e ELY (1976) quando analisaram as razões pelas quais os cientistas usam inadequadamente as bibliotecas e sistemas de informação. De acordo com esses pesquisadores, os motivos podem ser sintetizados em cinco atitudes principais:

a) ignorar a existência de bibliotecas e sistemas nas áreas específicas de interesse;

b) conhecer apenas superficialmente seus serviços;

c) inexplorar de modo profundo a capacidade dos sistemas;

d) desconhecer os pontos de acesso aos serviços;

e) dessaber seus benefícios e suas reais possibilidades.

\subsubsection{Participação em Listas de Discussão}

(cf. Tabela 5.1.4.1, AC \#02/5 - Apêndice B)

O objetivo é verificar se os usuários do IFUSP estão se utilizando de listas de discussão para contatar pessoas com interesses similares, trocar experiência e discutir pontos em comum.

Muito embora esses recursos, em geral, estejam recebendo bastante atenção por parte da comunidade de usuários das RE internacionais e nacionais, essa não parece ser a situação desta população. Apenas $14 \%$ desses usuários (sendo $22 \%$ dos alunos e $11 \%$ dos professores) estão atualmente participando de listas nas áreas de Física, Informática e outras de cunho geral. Funcionários e pesquisadores, em sua totalidade, não estão inscritos em nenhuma delas.

Como a maioria dos informantes utiliza quase diariamente o correio eletrônico, e somente uma pequena minoria está envolvida com grupos de discussão, pode-se pressupor que seus contatos e troca de correspondência sejam acentuadamente mterpessoais um a um, com pares e colegas de trabalho. Porém vale relembrar que: 
a) existem nas RE grupos de discussão "restritos" semelhantes ao "colégio invisível". Com número seleto de participantes, matem sigilo de suas atividades, componente e, principalmente, temas e idéias em discussão. Com certeza grupos no gênero já se organizam na área de Física.

b) a metade dos usuários utilizam o USENET várias vezes por semana, o que talvez seja uma forma mais interessante de participar de grupos de discussão conforme a disponibilidade individual.

TABELA 5.1.4.1

PARTICIPAÇÃO EM LISTAS DE DISCUSSÃO $\times$ CLASSES DE USUÁRIOS DA REDE IFUSP

\begin{tabular}{|c|c|c|c|c|c|c|c|c|c|c|c|}
\hline \multirow{2}{*}{ CATEGORIAS USUÁRIOS } & \multicolumn{4}{|c|}{ ALUNO } & \multicolumn{4}{|c|}{ DOCENTE } & \multirow{2}{*}{$\frac{\text { PESQ }}{P D}$} & \multirow{2}{*}{$\begin{array}{r}\text { FUNC } \\
\text { GR } \\
\end{array}$} & \multirow[t]{2}{*}{ TOTAL } \\
\hline & $G R$ & $\mathrm{ME}$ & DR: & ST & DR & $\mathrm{PD}$ & LD & ST & & & \\
\hline Não participa & 4 & 8 & 20 & 32 & 19 & 1 & 2 & 22 & 9 & 8 & 71 \\
\hline Participa & & & & & & & & & & & \\
\hline área de Física & - & 1 & 1 & 2 & 1 & - & - & 1 & - & - & 3 \\
\hline area de Informática & - & 4 & - & 4 & - & - & 1 & 1 & - & - & 5 \\
\hline áreas diversas & 1 & - & 2 & 3 & - & 1 & - & 1 & - & - & 4 \\
\hline$S / R$ & - & - & 2 & 2 & 2 & - & - & 2 & - & - & 4 \\
\hline TOTAL & 5 & 13 & 25 & 43 & 22 & 2 & 3 & 27 & 9 & 8 & 87 \\
\hline
\end{tabular}

\subsubsection{Propósitos de Uso das RE}

(cf. Tabela 5.1.5.1, AC \#02/4 - Apêndice B)

Buscou-se evidenciar a perspectiva que os usuários têm quanto às possibilidades do uso das RE. O esquema para análise de conteúdo dos dados coletados neste tópico foi desenvolvido indutivamente.

Razoável número de usuários (21\%) menciona genericamente que utiliza a rede para o desempenho de uma de suas três funções básicas, quais sejam: comunicar-se através do correio eletrônico, transferir arquivos via FTP de casa para o instituto, do escritório para o VAx e executar programas em computadores maiores via conexão remota. 
Outro grupo de usuário, também com respostas bastante gerais, corresponde aos que utilizam as RE como auxílio e desenvolvimento de pesquisa, para fins científicos, para desempenho de atividades profissionais ou para "trabalho". Tendo em vista que o objetivo básico da rede IFUSP e servir a pesquisa, e que seus integrantes são todos membros de equipes de projetos nos diversos departamentos, agruparam-se essas respostas no item "Apoio "a pesquisa", o qual corresponde a 22\% da amostra. Esse resultado pode significar que a rede, além de ser um instrumento de comunicação e troca de informações, passa a ser uma ferramenta prática ligada as atividades dos profissionais em apreço.

Os propósitos restantes (58\%) mais específicos permitem estabelecer outras categorias. Verifica-se que o principal motivo alegado para se utilizar a rede é o intercâmbio de informações técnico-científicas em geral, representando 16\%. De maneira mais particular, foram ainda mencionados os propósitos de:

- obter artigos e pré-prints (8\%);

- checar notícias do IFUSP (7\%);

- adquirir softwares específicos da área de interesse (6\%);

- acompanhar o estado de arte, novas publicações (6\%);

- efetuar buscas bibliográficas (4\%).

A somatória dessas categorias acima, as quais envolvem procedimentos de busca de informações de teor variado, perfaz o total de $47 \%$ dos motivos específicos alegados. Isto poderia ser considerado um forte incentivo para usar vários serviços de recuperação de informação. Porém, no item 5.1.3, anterior, foi evidenciado o quase total desconhecimento, e/ou não uso, de tais serviços e recursos.

Outra série de propósitos refere-se a comunicação interpessoal. Suas categorias foram assim distribuídas:

- contatar pares no país ou no exterior (13\%);

- contatar amigos e colegas (12\%);

- desenvolver pesquisas em colaboração (7\%);

- acompanhar listas de discussão (2\%);

- contatar institutos, Laboratórios e agendas de fomento (4\%).

A somatória dessas cinco categorias (38\%) e significativa se forem considerados os resultados anteriores que indicam o uso diário do email por grande número de informantes. Esse resultado vem ao encontro das conclusões já preconizadas em vários outros estudos quanto á importância do contato informal no processo de comunicação científica. Possível mente, trata-se do "colégio invisível eletrônico" formalizando-se gradativamente. 
TABELA 5.1.5.1

\section{PROPÓSITOS DE USO DA REDES ELETRÔNICAS $X$ CLASSES DE USUÁRIOS DA REDE IFUSP}

\begin{tabular}{|c|c|c|c|c|c|c|c|c|c|c|c|}
\hline \multirow[b]{2}{*}{ CATEGORIAS } & \multicolumn{4}{|c|}{ ALUNO } & \multicolumn{4}{|c|}{ DOCENTE } & \multirow{2}{*}{$\frac{\text { PESQ }}{\text { PD }}$} & \multirow{2}{*}{\begin{tabular}{|c|} 
FUNC \\
GR
\end{tabular}} & \multirow[t]{2}{*}{ TOTAL } \\
\hline & GR & ME & $\mathrm{DR}$ & ST & DR & $\mathrm{PD}$ & LD & ST & & & \\
\hline $\begin{array}{l}\text { UTILIZAR FUNÇŌES } \\
\text { BÁSICAS DAS RE'S }\end{array}$ & - & - & 5 & 5 & 7 & 2 & 1 & 10 & 2 & 1 & 18 \\
\hline APOIO Ả PESQUISA & 3 & 1 & 5 & 9 & 6 & 1 & 1 & 8 & 2 & - & 19 \\
\hline Sub-total & 3 & 1 & 10 & 14 & 13 & 3 & 2 & 18 & 4 & 1 & 37 \\
\hline $\begin{array}{l}\text { PROPÓSITO ESPECÍFICO } \\
\text { Contatar pares no país } \\
\text { e no exterior }\end{array}$ & - & - & & 4 & 5 & - & - & 5 & 2 & 2 & 13 \\
\hline Contatar amigos e colegas & 2 & 4 & 5 & 11 & - & - & - & - & 1 & - & 12 \\
\hline $\begin{array}{l}\text { Acompanhar listas de } \\
\text { discussões }\end{array}$ & - & 1 & - & 1 & - & - & - & - & 1 & - & 2 \\
\hline $\begin{array}{l}\text { Contatar institutos, labs. e } \\
\text { agências de fomento }\end{array}$ & - & - & 1 & 2 & 1 & - & - & 1 & 1 & 1 & 4 \\
\hline $\begin{array}{l}\text { Desenvolver pesquisa em } \\
\text { colaboração }\end{array}$ & - & - & - & - & 4 & - & 1 & 5 & 1 & 1 & 7 \\
\hline Efetuar busca bibliográfica & - & 1 & 2 & 3 & 1 & - & - & 1 & - & - & 4 \\
\hline Obter artigos e pré-prints & - & 3 & 1 & 4 & 1 & - & 1 & 2 & 2 & - & 8 \\
\hline Adquirir softwares & 1 & 1 & - & 2 & 1 & - & - & 1 & - & 3 & 6 \\
\hline Checar News do IFUSP & 1 & 2 & 2 & 5 & - & - & - & - & 1 & 1 & 7 \\
\hline Intercambiar informaçāo & 1 & 4 & 3 & 8 & 1 & - & - & 1 & 3 & 3 & 15 \\
\hline $\begin{array}{l}\text { Acompanhar estado da } \\
\text { arte, atualizar-se }\end{array}$ & - & 1 & 1 & 2 & 1 & - & - & 1 & 1 & 2 & 6 \\
\hline $\begin{array}{l}\text { Curiosidade, lazer, cultura } \\
\text { geral }\end{array}$ & - & 3 & 2 & 5 & 2 & - & 1 & 3 & 2 & 1 & 11 \\
\hline Sub-total & 5 & 20 & 21 & 46 & 17 & - & 3 & 20 & 16 & 14 & 95 \\
\hline Outros & - & 1 & 1 & 2 & - & - & - & - & - & - & 2 \\
\hline$S / R$ & - & - & 1 & 1 & - & - & - & - & - & - & 1 \\
\hline TOTAL & 8 & 22 & 33 & 63 & 30 & 3 & 5 & 38 & 20 & 15 & 135 \\
\hline
\end{tabular}


Dentre os docentes, as categorias "contatar pares no país e no exterior" e "desenvolver pesquisas em colaboração" são as de maior peso. Peso que se torna mais relevante ao se analisar o trabalho de ELLIS, COX e HALL (1993), que pesquisando padrões de busca de informação entre Físicos, apontaram o contato pessoal como ponto de partida para abordar novos tópicos de pesquisa, tendo grande importância na atualização e intercâmbio dentro de sua própria área.

As categorias eleitas pelos docentes confirmam a opinião de DOTY (1992) quanto a importância das RE na aproximação geográfica a fim de desenvolver atividades em colaboração [cf. cap. 2].

Já os alunos e os pesquisadores em pós-doutoramento apresentam como foco de preocupação, o "intercâmbio de informações em geral". Intercâmbio que também reitera teoria de DOTY (1992) quanto ao crescimento das redes inter-grupos. Essa categoria e a "aquisição de softwares" são preferidas pelos funcionários.

Os demais propósitos específicos apresentados tratam de curiosidades, lazer, cultura geral e interesses particulares.

\subsubsection{Barreiras / Dificuldades no Uso das RE}

\section{(cf. Tabela 5.1.6.1, AC \#02/6 - Apêndice B)}

Visando identificar problemas que os usuários têm defrontado ao utilizar as redes eletrônicas, foi-Ihes indagado sobre possíveis barreiras/ dificuldades no uso das redes.

O dado mais importante detectado de que 49,5\% dos informantes afirmam não ter dificuldades ao usar as redes. Esse resultado veio ao encontro das expectativas, pois que os informantes tem vivência no uso dos computadores. Além disso, somam-se o número de anos que a rede IFUSP já se encontra conectada as redes internacionais, a prática que a maioria da população usuária vem absorvendo as facilidades de acesso em todas as unidades do Instituto e a capacitação do corpo técnico e de apoio do CCIFUSP.

Os problemas apontados pelo restante dos informantes $(50,5 \%)$ são, na realidade, barreiras naturais encontradas em qualquer ambiente eletrônico, as quais foram analisadas, classificados e agrupadas indutivamente.

Entre elas, a que recebe maior destaque, com 26,4\% de respostas, é a categoria que engloba problemas físicos, do tipo: lentidão nas redes, congestionamento, dificuldades para conexão e transmissão de dados. Em seguida, vem problemas de ordem pessoal como desconhecimento de recursos e serviços disponíveis nas redes (10\%), falta de noções básicas sobre comandos, regras e normas (7\%), e falta de treinamento (1\%). Problemas lingüísticos como "instances demasiadamente técnicas, acessíveis apenas a especialistas" também foram identificados (3,45\%). 
Apesar de mais da metade dos informantes não conheçam e/ou nunca utilizam a maioria dos recursos e serviços disponíveis nas RE apenas 10\% indicam que isso tem sido problema para a utilização das redes, em toda sua potencialidade.

\section{TABELA 5.1.6.1}

\section{BARREIRAS NO USO DAS REDES ELETRÔNICAS x CLASSES DE USUÁRIOS DA REDE IFUSP}

\begin{tabular}{|c|c|c|c|c|c|c|c|c|c|c|c|}
\hline \multirow{2}{*}{ CATEGORIAS } & \multicolumn{4}{|c|}{ ALUNO } & \multicolumn{4}{|c|}{ DOCENTE } & \multirow{2}{*}{$\begin{array}{c}\text { PESQ } \\
\text { PD } \\
\end{array}$} & \multirow{2}{*}{$\begin{array}{c}\text { FUNC } \\
\text { GR } \\
\end{array}$} & \multirow[t]{2}{*}{ TOTAL } \\
\hline & GR & ME & DR & ST & DR & PD & LD & ST & & & \\
\hline Näo tem dificuldade & 3 & 5 & 10 & 18 & 14 & - & 3 & 17 & 5 & 3 & 43 \\
\hline $\begin{array}{l}\text { Falta conhecimento } \\
\text { básico }\end{array}$ & - & 1 & - & 1 & 2 & - & - & 2 & - & 3 & 6 \\
\hline $\begin{array}{l}\text { Desconhece recursos e } \\
\text { serviços disponiveis } R E\end{array}$ & - & 4 & 4 & 8 & - & - & - & - & - & - & 8 \\
\hline Problemas técnicos & 1 & 3 & 8 & 12 & 4 & 2 & - & 6 & 4 & 1 & 23 \\
\hline Falta treinamento & - & - & - & - & - & - & - & - & - & 1 & 1 \\
\hline Instruçōes muito técnicas & 1 & - & 1 & 2 & 1 & - & - & 1 & - & - & 3 \\
\hline Outros problemas & - & - & 2 & 2 & - & - & - & - & - & - & 2 \\
\hline$S / R$ & - & - & - & - & 1 & - & - & 1 & - & - & 1 \\
\hline TOTAL & 5 & 13 & 25 & 43 & 22 & 2 & 3 & 27 & 9 & 8 & 87 \\
\hline
\end{tabular}

\subsubsection{Dificuldades no acesso a informação via rede}

(cf. Tabela 5.1.7.1, AC \#02/7 - Apêndice B)

Visa evidenciar a existência ou não de dificuldades quanto "a identificação, a Iocalização, a interpretação e a recuperação da informação.

Também, neste item, 51\% dos informantes indicam não estar tendo dificuldades em acessar informações nas RE. Isto parece razoável, dado o longo tempo de 
experiência com computadores e com as redes. Porém, conforme resultados anteriores, mais da metade desses informantes desconhecem e/ou nunca utilizam os serviços de recuperação de informação disponíveis. Aliás, 7\% dos informantes responderam, literalmente, nunca terem utilizado a rede para buscar informação, e apenas 5\% mencionam o desconhecimento desses recursos como barreiras no acesso a informação.

TABELA 5.1.7.1

DIFICULDADES NO ACESSO À INFORMAÇÃO $x$ CLASSES DE USUÁRIOS DA REDE IFUSP

\begin{tabular}{|c|c|c|c|c|c|c|c|c|c|c|c|}
\hline \multirow[b]{2}{*}{ CATEGORIAS } & \multicolumn{4}{|c|}{ ALUNO } & \multicolumn{4}{|c|}{ DOCENTE } & \multirow{2}{*}{\begin{tabular}{|c|} 
PESQ \\
PD \\
\end{tabular}} & \multirow{2}{*}{$\begin{array}{c}\text { FUNC } \\
\text { GR } \\
\end{array}$} & \multirow[t]{2}{*}{ TOTAL } \\
\hline & GR & ME & DR & ST & DR & PD & LD & ST & & & \\
\hline Não tem dificuldade & 3 & 4 & 11 & 18 & 13 & 1 & 2 & 16 & 6 & 5 & 45 \\
\hline $\begin{array}{l}\text { Nunca utiliza RE para } \\
\text { buscar informação }\end{array}$ & - & 1 & - & 1 & 4 & - & - & 4 & 1 & - & 6 \\
\hline $\begin{array}{l}\text { Falta conhecimento } \\
\text { básico }\end{array}$ & & 2 & 1 & 3 & 1 & - & - & 1 & - & 1 & 5 \\
\hline $\begin{array}{l}\text { Desconhece recursos e } \\
\text { serviços disponiveis RE }\end{array}$ & - & 1 & 3 & 4 & - & - & - & - & - & - & 4 \\
\hline Carência de organização & - & 1 & 4 & 5 & 1 & 1 & - & 2 & - & 1 & 8 \\
\hline $\begin{array}{l}\text { Problemas com endereça- } \\
\text { mento eletrônico }\end{array}$ & - & 1 & 1 & 2 & - & - & - & - & 1 & - & 3 \\
\hline Instruçōes muito técnicas & 1 & 1 & 2 & 4 & - & - & - & - & - & - & 4 \\
\hline $\begin{array}{l}\text { Não confiabilidade nos } \\
\text { dados }\end{array}$ & - & 1 & 2 & 3 & - & - & - & - & 1 & 1 & 5 \\
\hline Outros & - & 1 & 1 & 2 & 1 & - & - & 1 & - & - & 3 \\
\hline$S / R$ & 1 & - & - & 1 & 2 & - & 1 & 3 & - & - & 4 \\
\hline TOTAL & 5 & 13 & 25 & 43 & 22 & 2 & 3 & 27 & 9 & 8 & 87 \\
\hline
\end{tabular}

Obs.: Questão múltipla 
Dentre os demais informantes (41,38\%), várias dificuldades apontadas fornecem a ferramenta para categorizar indutivamente os problemas que tem sido defrontados por eles. O mais relevante deles é a carência de organização nas redes, causando dificuldades na recuperação da informação. A falta de conhecimentos básicos para o perfeito controle do meio eletrônico representa empecilho para uns poucos.

Bastante peculiar d o fato que, mesmo dentre informantes tão ágeis no uso de computadores e em questões de informa'tica, foi indicada levantada a questão da terminologia excessivamente técnica utilizada nos manuais de auxilio aos usuários (apontada por $4,5 \%$ dos informantes). Isto nos leva a considerar que essa terminologia se transforma em barreira para usuários de áreas menos afeitas ao desenvolvimento tecnológico. A dificuldade, indicada por alguns, em compreender endere9amentos eletrônicos denota a ausência de limites claros entre as varias redes, problema este já identificado anteriormente neste trabalho.

\subsubsection{Treinamento para o Uso das RE}

(cf. Tabela 5.1.8.1, AC \#02/8 - Apêndice B)

Um aspecto interessante analisado refere-se às diferentes estratégias empreendidas pelos usuários para aprender a utilizar as redes e seus recursos, uma vez que 98\% deles nunca tiveram nenhuma espécie de treinamento formal.

A estratégia de trocar informações com amigos e pessoas ao lado em contatos informais é mencionada $47 \%$ das vezes, sendo que os alunos (em especial os doutorandos) e os funcionários são os que mais a utilizam. Já foi comprovado em vários outros estudos que a lei do menor esforço vigora também entre pessoas que buscam informações. Assim, não causa estranheza tal resultado.

O segundo procedimento mais comum o auto-aprendizado (29\%), através da prática, navegação, tentativa e erros. É a estratégia mais utilizada pelos docentes (37,5\%). O autodidatismo já fora aontado por RAITT (apud CLAUSEN, 1992) como uma barreira no processo de comunicação.

O uso de manuais impressos e automatizados (help online) e arquivos de "FAQ" faz parte do rol de estratégias, sendo designada em 13\% das vezes. Dentre os pesquisadores em pós-doutorado, essa foi à estratégia mais utilizada (33\%).

Em menor proporção verifica-se o recurso de se pesquisar o serviço de News coordenado pelo Centre de Computadores do IFUSP (4,5\%). Esse e o Serviço o qual 93\% dos informantes disseram, anteriormente, nunca ter utilizado. Portanto, reafirmamos nossa dedução que uns poucos usuários tem tirado proveito dele. 
A estratégia que menos tem sido empreendida pelos usuários e a procura de especialistas e/ou operadores do sistema, aqueles que, em tese, são os melhores preparados e capacitados a atender, instruir e alertar quanto a novos serviços, recursos e facilidades.

TABELA 5.1.8.1

TREINAMENTO PARA O USO DE REDES ELETRÔNICAS $x$ CLASSES DE USUÁRIOS DA REDE IFUSP

\begin{tabular}{|c|c|c|c|c|c|c|c|c|c|c|c|}
\hline \multirow[b]{2}{*}{ CATEGORIAS } & \multicolumn{4}{|c|}{ ALUNO } & \multicolumn{4}{|c|}{ DOCENTE } & \multirow{2}{*}{\begin{tabular}{|c|} 
PESQ \\
PD \\
\end{tabular}} & \multirow{2}{*}{$\frac{\text { FUNC }}{\text { GR }}$} & \multirow[t]{2}{*}{ TOTAL } \\
\hline & GR & ME & DR & ST & DR & PD & LD & ST & & & \\
\hline \multicolumn{12}{|l|}{$\begin{array}{l}\text { TREINAMENTOS } \\
\text { INFORMAIS }\end{array}$} \\
\hline aprendeu sozinho & 1 & 5 & 9 & 15 & 9 & 1 & 2 & 12 & 3 & 2 & 32 \\
\hline consultou manuais & - & 1 & 4 & 5 & 3 & 1 & - & 4 & 5 & - & 14 \\
\hline perguntou a especialistas & $\cdot$ & - & - & - & - & 1 & - & 1 & 1 & 1 & 3 \\
\hline questionou amigos & 2 & 8 & 16 & 26 & 7 & - & 1 & 8 & 4 & 3 & 41 \\
\hline pesquisou NEWS IFUSP & - & 1 & 3 & 4 & - & - & - & - & 1 & $\cdot$ & 5 \\
\hline outros & 1 & 3 & - & 4 & 5 & - & 1 & 6 & 1 & 2 & 13 \\
\hline \multicolumn{12}{|l|}{ TREINAMENTOS } \\
\hline FORMAIS & 1 & - & - & 1 & - & - & - & - & - & - & 1 \\
\hline S/R & - & - & - & - & 1 & - & - & 1 & - & & 1 \\
\hline TOTAL & 5 & 15 & 32 & 55 & 25 & 3 & 4 & 32 & 15 & 8 & 110 \\
\hline
\end{tabular}

OBS.: questão múltipla 


\section{ANÁLISE II}

\subsection{BUSCA E USO DA INFORMAÇÃO VIA REDE}

\subsubsection{Contexto da utilização das RE}

(cf. Tabela 5.2.1.1 AC\#03 - Apêndice B)

Partindo da análise de todas as situações narradas individualmente pelos usuários, é possível estabelecer indutivamente, os vários contextos situacionais que vem favorecendo o uso da RE. Na realidade, a elaboração do esquema de identificação e classificação das categorias a serem utilizadas na tabulação dos dados compreende uma das principais inferências deste estudo.

Dentre a população estudada, detectam-se quatro abrangentes contextos situacionais provocando o uso das RE.

\section{CONTEXTO I}

Trata-se da utilização das RE para aquisição de conhecimentos sobre a própria rede. Subdivide-se em:

a) conhecimentos gerais e básicos sobre a rede; contribuições para o desempenho profissional; questionamentos sobre medidas de segurança e legalidade da informação

b) dados específicos sobre os serviços disponíveis nas RE, suas formas de acesso, manuseio e recuperação da informação.

Apenas 6\% dos informantes são categorizadas dentro deste contexto, sendo que $80 \%$ deles se referem à aquisição de conhecimentos gerais. Deduz-se que pequeno número de representantes do alunado (8\%) e dos docentes (7,5\%) estão ainda buscando entender as vantagens, possibilidades e potencialidades das RE.

\section{CONTEXTO II}

Refere-se ao uso exclusivo das RE para desenvolvimento de suas funções básicas, Compreende duas subcategorias:

a) comunicação pessoa-vs-pessoa: contato com colegas, pares, enfim, comunicação interpessoal em geral; e,

b) comunicação homem-vs-máquina: conexão com outras máquinas, a fim de transferir arquivos ou resultados de estudo e utilizar programas armazenados em computadores remotos.

Classificaram-se, neste Contexto II, 36\% do total de informantes. Analisando por classes de usuário, verifica-se que $50 \%$ dos docentes, $34 \%$ do alunado e 
28,5\% dos funcionários vêm utilizando a rede exclusivamente com o intuito de lançar mão do email, FTP ou Telnet. Como, na pratica, os docentes contam com o auxílio de seus alunos de iniciação científica ou de pós-graduação para desenvolver atividades de coleta de dados, levantamentos bibliográficos e soluções de problemas rápidos e cotidianos, é compreensível que metade deles utilizem as RE de modo mínimo, ou seja, apenas nas suas funções básicas e ainda localmente.

\section{CONTEXTO III}

Refere-se á busca de soluções imediatas para problemas específicos relacionados às atividades profissionais e/ou pessoais. Subdivididos em:

a) questões envolvendo procedimentos técnicos - busca de normas, instruções para instalação, uso, características técnicas de softwares;

b) questões administrativas e pessoais - importação de materiais, conta em redes externas, problemas de documentação pessoal;

c) questões envolvendo intercâmbio e prestação de serviços - envio de artigos para revisão e/ou publicação, convênios e acordos internacionais.

Aqui recaem $30 \%$ das situações relatadas pelos informantes. A classe de usuários que se sobressai é a de funcionários, com $43 \%$; seguido pelos alunos, com $34 \%$. Pesquisadores $(28,5 \%)$ e docentes (19\%) também recorrem às redes buscando soluções a problemas.

Considerando que os objetivos dos funcionários são evidentemente pontuais, isto é, transpor barreiras decorrentes de suas atividades profissionais o mais rápido e da melhor maneira possível, fica muito claro entender o grande número deles buscando as RE para solucionar problemas imediatos. Os alunos buscam soluções para problemas técnicos, em sua maioria, provavelmente cumprindo determinações dos seus orientadores de pesquisas.

\section{CONTEXTO IV}

Trata-se da utilização da rede eletrônica para buscar informação e/ou dado técnicocientifico para desenvolvimento de atividades de pesquisa. Subdivide-se em:

a)informação bibliográfica - engloba utilização das RE para efetuar levantamentos

bibliográficos, buscas de referências bibliográficas completas, bibliografia;

b)informação não-bibliográfica - inclui levantamento de softwares em geral, busca de tabelas, dados estatísticos;

c)informação rápida / momentânea - compreende atividades de localização de software específico, endereço de máquinas, pessoas e repositórios públicos;

d)informação para atualização - arrola a busca de dados para "reciclagem" profissional, acompanhamento do estado-da-arte e da literatura especializada na área. 
A busca destes variados tipos de informação tem levado 28\% dos informantes a utilizar as RE. Esse contexto situacional e o que apresenta maior número de pesquisadores em pósdoutoramento $(71,4 \%)$ utilizando a rede. Já as demais classes, ficaram assim distribuídas: $28,5 \%$ dos funcionários, $24 \%$ do alunado e $23 \%$ dos docentes.

TABELA 5.2.1.1

CONTEXTO DE UTILIZAÇÃO DAS RE $X$ CLASSES DE USUÁRIOS DA REDE IFUSP

\begin{tabular}{|c|c|c|c|c|c|c|c|c|c|c|c|}
\hline \multirow{2}{*}{ CATEGORIAS USUÁRIOS } & \multicolumn{4}{|c|}{ ALUNO } & \multicolumn{4}{|c|}{ DOCENTE } & \multirow{2}{*}{$\frac{P E S Q}{P D}$} & \multirow{2}{*}{$\frac{\text { FUNC }}{\text { GR }}$} & \multirow[t]{2}{*}{ TOTAL } \\
\hline & GR & ME & DR & ST & DR & PD & LD & ST & & & \\
\hline $\begin{array}{l}\text { ADQUIRIR CONHECIMENTO } \\
\text { SOBRE RE } \\
\text { dados gerais } \\
\text { serviços das RE }\end{array}$ & - & & \begin{tabular}{l|}
2 \\
-
\end{tabular} & $\begin{array}{l}2 \\
1\end{array}$ & $\begin{array}{l}2 \\
-\end{array}$ & - & - & $\begin{array}{l}2 \\
-\end{array}$ & - & - & $\begin{array}{l}4 \\
1\end{array}$ \\
\hline $\begin{array}{l}\text { COMUNICAR-SE } \\
\text { pessoa-a-pessoa } \\
\text { pessoa-a-máquina }\end{array}$ & - & $\begin{array}{l}3 \\
-\end{array}$ & $\begin{array}{l}7 \\
3\end{array}$ & $\begin{array}{c}10 \\
3\end{array}$ & $\begin{array}{l}4 \\
6\end{array}$ & - & $\begin{array}{l}2 \\
1\end{array}$ & $\begin{array}{l}6 \\
7\end{array}$ & - & - & $\begin{array}{l}16 \\
12\end{array}$ \\
\hline $\begin{array}{l}\text { BUSCAR SOLUÇŌES PARA } \\
\text { PROBLEMAS }\end{array}$ & & & & & & & & & & & \\
\hline $\begin{array}{l}\text { técnicos } \\
\text { administrativos e/ou pessoais } \\
\text { intercâmbio }\end{array}$ & $\begin{array}{l}2 \\
- \\
-\end{array}$ & $\begin{array}{l}4 \\
- \\
-\end{array}$ & \begin{tabular}{l|l}
3 & -1 \\
3 & \\
1 &
\end{tabular} & $\begin{array}{l}9 \\
3 \\
1\end{array}$ & $\begin{array}{l}- \\
2 \\
2\end{array}$ & $\begin{array}{l}1 \\
- \\
-\end{array}$ & $\begin{array}{l}- \\
-\end{array}$ & $\begin{array}{l}1 \\
2 \\
2\end{array}$ & $\begin{array}{l}- \\
1 \\
1\end{array}$ & $\begin{array}{l}2 \\
1 \\
-\end{array}$ & $\begin{array}{l}12 \\
7 \\
4\end{array}$ \\
\hline $\begin{array}{l}\text { BUSCAR INFORMAÇÃO } \\
\text { bibliográfica } \\
\text { năo bibliográfica } \\
\text { rápida e momentânea } \\
\text { para atualização }\end{array}$ & $\begin{array}{l}- \\
- \\
- \\
1\end{array}$ & $\begin{array}{l}1 \\
- \\
3 \\
-\end{array}$ & \begin{tabular}{l|l}
1 & -1 \\
2 & \\
- & -1 \\
1 &
\end{tabular} & $\begin{array}{l}2 \\
2 \\
3 \\
2\end{array}$ & $\begin{array}{l}3 \\
1 \\
1 \\
1\end{array}$ & $\begin{array}{l}- \\
- \\
-\end{array}$ & $\begin{array}{l}- \\
- \\
-\end{array}$ & $\begin{array}{l}3 \\
1 \\
1 \\
1\end{array}$ & $\begin{array}{l}1 \\
2 \\
- \\
2\end{array}$ & $\begin{array}{l}2 \\
- \\
- \\
-\end{array}$ & $\begin{array}{l}8 \\
5 \\
4 \\
5\end{array}$ \\
\hline Sub-total & 3 & 12 & 23 & 38 & 22 & 1 & 3 & 26 & 7 & 7 & 73 \\
\hline$S / R$ & 2 & 1 & 2 & 5 & - & 1 & - & 1 & 2 & 1 & 9 \\
\hline TOTAL & 5 & 13 & 25 & 43 & 22 & 2 & 3 & 27 & 9 & 8 & 87 \\
\hline
\end{tabular}




\subsubsection{Natureza da Questão do Usuário}

(cf. Tabelas 5.2.2.1 e 5.2.2.2, AC \#04 - Apêndice B)

Este subcapítulo e os subseqüentes visam apresentar o resultado das análises de conteúdo desenvolvidas, tendo como unidade de registro a questão formulada pelo usuário no item 3.4 do instrumento de coleta de dados.

Aqui se interpretam os resultados quanto à natureza dessa questão, o próximo subcapltulo analisa o seu foco. Em seguida, vem às estratégias desenvolvidas pelos usuários para buscar resposta, o auxilio obtido, o esforço empreendido pelo usuário para localizar a resposta, seu nível de satisfação, a fonte que efetivamente auxiliou e os vários recursos informacionais utilizados.

A natureza das questões colocadas pelos usuários é analisada em termos de seis categorias principais:

a) "o que" - busca a identidade de "algo" que não é precisamente uma pessoa, é um objeto ou coisa;

b) "quem" - objetiva identificar uma ou mais pessoas;

c) "onde" - procura localizar algo espacialmente;

d) "quando" - procura localizar algo temporalmente;

e) "como" - intenta definir procedimentos ou habilidades necessárias para se mover de um local a outro no tempo e espaço;

f) "por que" - invoca as razões, causas e explicações das coisas.

Esse esquema foi baseado na classificação desenvolvida originalmente por DERVIN (1983a) e baseado no conhecido "Esquema 5W" (what, who, when, where, why, how ). Categorias do tipo "Outras respostas" e "Sem respostas" foram estabelecidas, tanto neste esquema como nos demais, visando atender o critério da inclusividade e exaustividade necessária as análises do gênero. Essa análise foi feita em 2 segmentos: (a) quanto às diferentes classes de usuários (tabela 5.2.2.1) e (b) quanto aos contextos de utilização das RE (tabela 5.2.2.2).

No primeiro segmento, observa-se que a categoria mais representativa da natureza das questões dos informantes gerais e o "Como" mencionado 34\% das vezes, seguido do "Onde" (21\%) e do "O que" (18\%).

Analisando-se por classe de usuário, deduz-se que dentre o:

a) alunado: a categoria "como" merece 34\% da atenção, sendo preenchida quase totalmente por alunos de doutorado. Em seguida, tem-se questões de identificação quanto "ao que" está disponível nas redes (25\%); 
b) docentes: também a busca de normas e procedimentos quanto ao uso das redes e seus aplicativos recebem maior número de citações ("como" - 40\%), e necessidades de localização das informações aparece posteriormente ("onde" - 27\%);

c) pesquisadores: já mostram um perfil diferenciado, suas preocupações maiores estão centradas na identificarão de elementos que possam auxiliá-los ("quem" - 28,5\%). A identificação do que existe disponível, onde e como acessar ocupam indiscriminadamente, o segundo piano.

c) funcionários: apresentam os mesmos problemas dos alunos e docentes, ou seja, buscam prioritariamente por procedimentos ("como" - 43\%). Em número menor vem a necessidade de identificação das disponibilidades ("o que" - 29\% ).

TABELA 5.2.2.1

\section{NATUREZA DA QUESTÃO DO USUÁRIO \\ $x$ CLASSES DE USUÁRIOS DA REDE IFUSP}

\begin{tabular}{l|cccc|c|cc|c|c|c|c|c}
\hline \multirow{2}{*}{ USUÁRIOS } & \multicolumn{3}{|c|}{ ALUNO } & \multicolumn{3}{c|}{ DOCENTE } & PESQ & FUNC & \multirow{2}{*}{ TOTAL } \\
\cline { 2 - 9 } CATEGORIAS & GR & ME & DR & ST & DR & PD & LD & ST & PD & GR & \\
\hline O QUE & - & 4 & 4 & 8 & 2 & - & - & 2 & 1 & 2 & 13 \\
QUEM & - & 1 & 1 & 2 & - & - & - & - & 2 & 1 & 5 \\
ONDE & 2 & 1 & 2 & 5 & 4 & - & - & 4 & 1 & 1 & 11 \\
QUANDO & 1 & - & 1 & 2 & - & - & - & - & 1 & - & 3 \\
COMO & - & 3 & 8 & 11 & 5 & 1 & - & 6 & 1 & 3 & 21 \\
POR QUE & - & 2 & 1 & 3 & 2 & - & - & 2 & - & - & 5 \\
OUTROS & - & - & 1 & 1 & - & - & - & - & - & - & 1 \\
SR & - & - & - & - & 1 & - & - & 1 & 1 & - & 2 \\
\hline Sub-total & 3 & 11 & 18 & 32 & 14 & 1 & - & 15 & 7 & 7 & 61 \\
\hline Incompletos/Anulados & 2 & 2 & 7 & 12 & 8 & 1 & 3 & 12 & 2 & 1 & 26 \\
\hline \hline \multicolumn{1}{r|}{ TOTAL } & 5 & 13 & 25 & 43 & 22 & 2 & 3 & 27 & 9 & 8 & 87 \\
\hline \hline
\end{tabular}


A segunda análise da natureza das questões - ou seja, em relação aos contextos de uso das redes (identificadas no subcapítulo anterior 4.2.1) - apresentou interessantes resultados. A categoria "O que" aparece com maior incidência nos contextos. de busca de informações (50\%), o que denota uma preocupação com a identificação da informação, qual e que tipo de dados estão disponível nas RE. A seguir, contextos envolvendo busca de soluções para problemas imediatos também demonstram questões buscando identificação de, por exemplo, softwares específicos, formulários adequados, entre outros (33\%). No contexto que envolve os procedimentos básicos de comunicação, questões "O que" também contemplam 17\%. Finalmente, quanto ao uso das RE para aquisição de conhecimento sobre ela própria, os informantes não parecem estar mais se preocupando com o que existe disponível, mas sim com a localização do que existe e com as formas de procedimentos para se obter os dados.

Já a categoria "Quem" e quase exclusivamente utilizada nas situações que envolvem a "Busca de soluções" (80\%), mostrando que a identificação de pessoas, o saber quem pode auxiliar na solução de problemas, ou de que fonte obter respaldo, e um ponto crucial. O total de 54,5\% das questões indagando a localização física / espacial de algo (ou seja, saber aonde ir, em que lugar encontrar determinada coisa, que dire9ão seguir) recai nas situações envolvendo a busca de informações técnico-científicas; mostrando as dificuldades que um bom número de usuários está. vivenciando quando tenta acessar informa95s nas RE.

A quarta categoria analisada, "Quando", envolvendo a localização temporal de algo, é mencionada $67 \%$ das vezes nos contextos de busca de soluções para problemas imediatos. Este contexto havia sido anteriormente identificado como o mais utilizado pelos funcionários, os quais por exigências profissionais, com certeza, necessitam se preocupar mais com questões envolvendo tempo.

A busca de procedimentos e normas adequadas - (representada pela categoria "Como") aparece distribuída equitativamente entre as situações de "Comunicação", "Busca de Soluções" e "Busca de Informações" (28,5\%) e na situação de "Aquisição de conhecimentos" - mencionada 19\% das vezes.

Finalmente, a última categoria analisada, referente ao "Por que", busca explicações, razões, propósitos, causas. De maneira geral, essa categoria e pouco utilizada pelos informantes, o que pode comprovar sua imaturidade no que diz respeito aos questionamentos mais profundo sobre as RE.

Observando-se especificamente o contexto que envolve apenas o uso das redes para "Comunicação", verifica-se que surgem tanto questões buscando identificação, localização espacial, localização temporal e explicações. Mas a maior incidência e de questões quanto aos procedimentos (50\%). Tendo em vista os resultados anteriores, que 
mostram o uso quase diário dos serviços básicos das RE esperava-se que os procedimentos de uso das redes, nessas condições, já estivessem sob controle.

TABELA 5.2.2.2

NATUREZA DA QUESTÃO DOS USUÁRIOS $\times$ CONTEXTO DE UTILIZAÇÃO DAS REDES ELETRÔNICAS

\begin{tabular}{|c|c|c|c|c|c|c|c|c|}
\hline CATEGORIAS & $\begin{array}{c}0 \\
\text { QUE } \\
\end{array}$ & QUEM & QUANDO & COMO & $\begin{array}{l}\text { POR } \\
\text { QUE }\end{array}$ & OUTROS & $S / R$ & TOTAL \\
\hline $\begin{array}{l}\text { ADQUIRIR CONHECI- } \\
\text { MENTO S/ RE }\end{array}$ & & & & & & & & \\
\hline dados gerais & - & - & - & 3 & - & - & - & 4 \\
\hline serviços da RE & - & - & - & 1 & - & - & - & 1 \\
\hline COMUNICAR-SE & & & & & & & & \\
\hline pessoa-a-pessoa & 2 & - & 1 & 3 & 2 & - & - & 8 \\
\hline pessoa-a-máq. & - & - & - & 3 & - & - & - & 4 \\
\hline BUSCAR SOLUÇŌES & & & & & & & & \\
\hline P/ PROBLEMAS & & & & & & & & \\
\hline técnicos & 4 & 2 & 1 & 3 & 1 & - & - & 12 \\
\hline administrativos/ pessoais & - & 2 & - & 1 & 1 & 1 & - & 6 \\
\hline intercàmbio & - & - & 1 & 2 & - & - & - & 4 \\
\hline BUSCAR INFORMAÇĀO & & & & & & & & \\
\hline bibliográfica & 3 & - & - & 2 & - & - & 1 & 8 \\
\hline não bibliográfica & - & 1 & - & 1 & - & - & $\cdot$ & 5 \\
\hline rápida e momentânea & 1 & - & - & 2 & 1 & - & - & 4 \\
\hline para atualização & 2 & - & - & 1 & - & - & 1 & 5 \\
\hline Sub-total & 12 & 5 & 3 & 22 & 5 & 1 & 2 & 61 \\
\hline Incompletos/Anulados & - & - & - & - & - & - & 26 & 26 \\
\hline TOTAL & 12 & 5 & 3 & 22 & 5 & 1 & 28 & 87 \\
\hline
\end{tabular}




\subsubsection{Foco da Questão do Usuário}

(cf. Tabela 5.2.3.1 e 5.2.3.2, AC \#05 - Apêndice B)

Um segundo tipo de análise das necessidades de informação dos usuários é quanto o foco das questões por eles apresentadas. Isto é, a identificação do núcleo central do problema do usuário, segundo sua própria ótica.

O esquema para essa análise de conteúdo e adaptado do modelo de Dervin (1983), e consta de seis categorias:

a) a própria pessoa - quando o foco recai sobre alguma habilidade essencial ao informante, ou uma necessidade de algo para decisões interiores.

b) outras pessoas - quando ha expectativa de solução de parte de outra (s) pessoa (s) ou profissional (is).

c) objeto ou coisa - quando o foco envolve algo concreto, tangível ou inanimado.

d) situação - subdividida em 3 grupos:

Situação 1 - foco da questão expressa na solução de um acontecimento genérico; solução essa que exige o desenvolvimento de trabalho especializado para ser obtida.

Situação 2 - envolvimento na própria rede, de maneira global.

Situação 3 - foco manifesta recurso/serviço específico da RE.

Duas análises quanto ao foco da questão foram desenvolvidas. A primeira expõe as diferentes classes de usuários (tabela 5.2.3.1) e a segunda revela os contextos de utilização das RE (tabela 5.2.3.2).

Quanto aos usuários, sua maior preocupação dá-se no conjunto de situação, representando $60 \%$ do total. A Situação 1 / genérica é a categoria individual com maior freqüência de citações (33\%), seguida da categoria "Objeto/coisa" (21\%). As Situações 2 e 3 recebem respectivamente $18 \%$ e $10 \%$ das menções. Percebe-se, portanto, que um ponto nevrálgico das necessidades de informação dos usuários, refere-se ao conhecimento e domínio dos procedimentos gerais envolvidos no processo de busca de informação, tanto externa quanto internamente as RE.

Os resultados por classe de usuário mostram que o foco principal das questões dos docentes (50\%), dos funcionários (42\%) e do alunado (27\%), apresenta-se na Situação 1, que envolve preocupação com os procedimentos genéricos arrolados em processos de busca de informação. Para os pesquisadores em pós-doutoramento, o foco principal se volta para a Situação 2 (43\%), ou seja, para os procedimentos envolvidos, especificamente, com a busca de informação via RE. 
TABELA 5.2.3.1

\section{FOCO DA QUESTÃO DO USUÁRIO \\ $X$ CLASSES DE USUÁRIOS DA REDE IFUSP}

\begin{tabular}{|c|c|c|c|c|c|c|c|c|c|c|c|}
\hline \multirow{2}{*}{ CATEGORIAS } & \multicolumn{4}{|c|}{ ALUNO } & \multicolumn{4}{|c|}{ DOCENTE } & \multirow{2}{*}{\begin{tabular}{r|} 
PESQ \\
PD \\
\end{tabular}} & \multirow{2}{*}{\begin{tabular}{|r|} 
FUNC \\
GR \\
\end{tabular}} & \multirow[t]{2}{*}{ TOTAL } \\
\hline & GR & $\mathrm{ME}$ & DR & ST & DR & PD & LD & ST & & & \\
\hline PRÓPRIA PESSOA & - & - & 3 & 3 & - & - & - & - & 1 & - & 5 \\
\hline OUTRA PESSOA & - & 2 & 1 & 3 & - & - & - & - & 1 & 1 & 5 \\
\hline OBJETO/COISA & 1 & 3 & 4 & 8 & 2 & 1 & - & 3 & - & 2 & 13 \\
\hline SITUAÇĀO 1 & 1 & 1 & 7 & 9 & 8 & - & - & 8 & - & 3 & 20 \\
\hline SITUAÇĀO 2 & 1 & 4 & 2 & 7 & - & - & - & - & 3 & 1 & 11 \\
\hline SITUAÇÄO 3 & - & 1 & 1 & 2 & 3 & - & - & 3 & 1 & - & 6 \\
\hline$S / R$ & - & - & -1 & - & 1 & - & - & 1 & 1 & - & 2 \\
\hline Sub-total & 3 & 11 & 18 & 32 & 14 & 1 & - & 15 & 7 & 7 & 61 \\
\hline Incompletos/Anulados & 2 & 2 & 7 & 11 & 8 & 1 & 3 & 12 & 2 & 1 & 26 \\
\hline TOTAL & 5 & 13 & 25 & 43 & 22 & 2 & 3 & 27 & 9 & 8 & 87 \\
\hline
\end{tabular}

Quanto à análise do foco das questões versus o contexto de utilização das RE, os resultados encontrados indicam que as categorias envolvendo as situações 1,2 e 3 são as mais presentes dentre os quatro grandes contextos de uso das RE.

Esse uso, quando exclusivamente voltado para as funções básicas de comunicação, tem suscitado nos usuários necessidades informacionais cujo foco maior tem sido a "Situação 1 / genérica" (58\%), seguida da Situação 3 / recursos das redes 
(17\%). Cruzando esses resultados com anteriores verifica-se que, de maneira geral, a maioria dos usuários utilizando as RE unicamente para comunicar-se com alguém, transferir arquivos ou conectar-se remotamente a outro computador tem se defrontado com problemas do tipo: determinação da maneira correta ou modo exato para resolver situações genéricas de busca de informação, que não especificamente envolvendo as RE ou seus recursos.

Quando o propósito de se utilizar a rede adquirir conhecimentos sobre a própria rede, o foco das questões dos usuários fica restrito as três situações, em que as "Situações1 e 3" são mencionadas por 40\% dos informantes respectivamente, e a "Situação 2", pelo restante (20\%). Comparando com resultados anteriores, percebe-se que tais informantes estão necessitando de auxílio para incorporar procedimentos adequados a solução de situações, tanto genéricas como as que envolvem as RE e seus recursos.

Quando buscando soluções para problemas imediatos, os informantes têm demonstrado não necessitar de maiores conhecimentos quanto às reais possibilidades, potencialidades e vantagens das RE. Precisam sim, tanto dos procedimentos genéricos envolvidos em uma busca de informação como também, de localizar, acessar e utilizar algo como softwares, aplicativos, e outros "objetos-chave" na solução de seus problemas.

A busca de informação técnico-científica, quando analisada em função das questões representativas das necessidades de informação da população, demonstra que 40,9\% dessas necessidades estão centradas na "Situação 2", portanto, envolvem as redes de maneira geral. Na análise da natureza da questão, fica evidenciado um equilíbrio entre as questões "o que", "onde" e "como". Somando esses resultados, percebe-se que usuários, utilizando a rede na tentativa de buscar informações técnico-científicas para desempenho de atividades de pesquisa, estão tendo problemas para identificar o que existe nas redes; qual a informação disponível; qual é sua localização exata e a forma adequada para obtê-la. A segunda preocupação ou foco dos informantes buscando informação centra-se na categoria "Objeto/Coisa", o que vem ao encontro do que foi mencionado logo acima: a preocupação dos usuários com uma informação definida. 


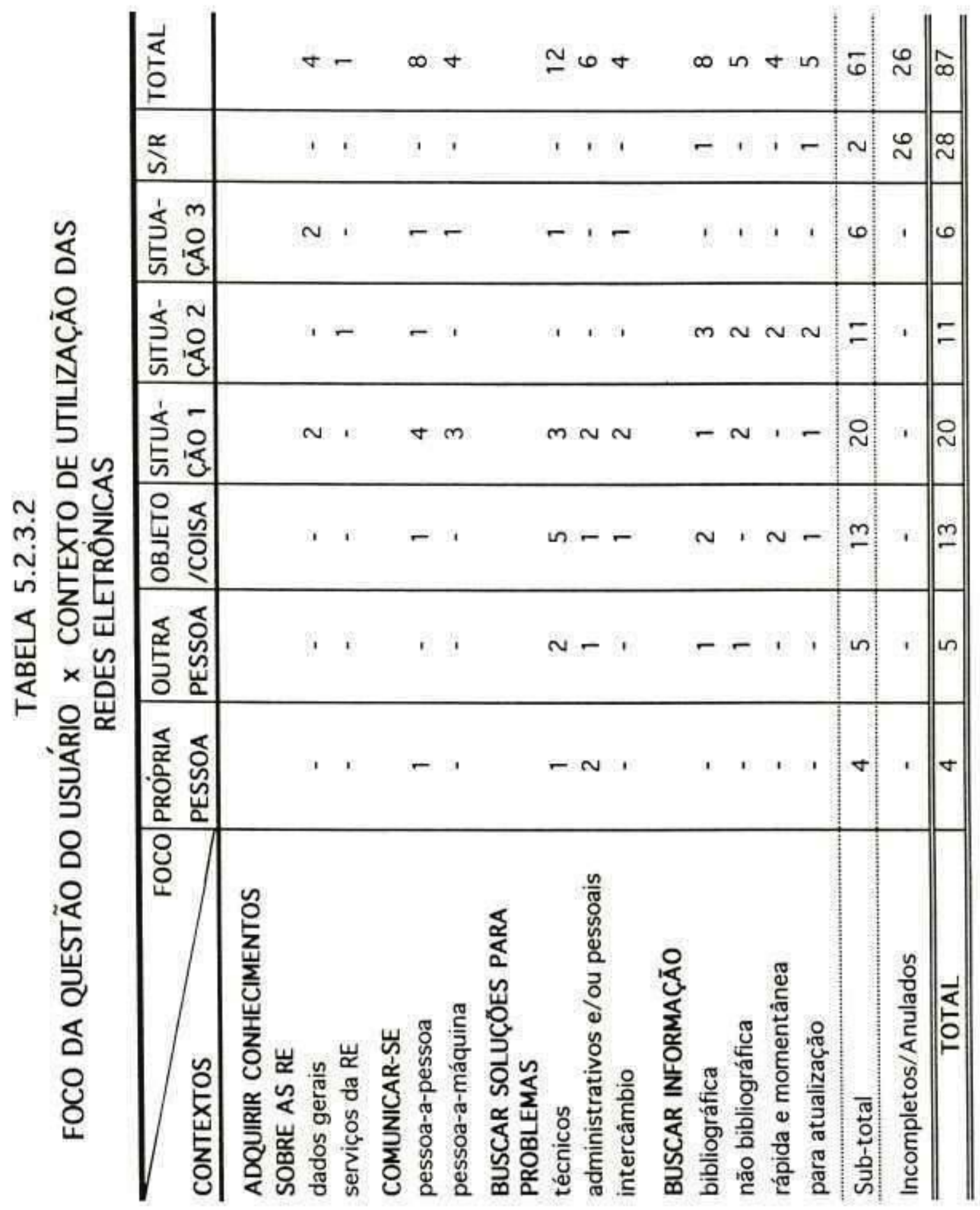




\subsubsection{Expectativa de Uso da informação}

(cf. Tabela 5.2.4.1, AC \#06- Apêndice)

Ao colocar uma questão, o usuário geralmente já tem idéia preconcebida de como a resposta poderá auxiliá-lo a resolver sua lacuna ou problema. Quando obtida, a resposta pode ser utilizada ou da forma como o usuário a visualizou, ou de uma maneira diferente do que esperava.

Esta análise fornece clara ilustração de como a população imagina os auxílios que receberiam com as respostas as suas questões. O esquema empregado e desenvolvido indutiva e dedutivamente - com adaptações de categorias previamente definidas por DERVIN (1983a).

TABELA 5.2.4.1

EXPECTATIVA DE USO DA INFORMAÇÃO $X$ CLASSES DE USUÁRIOS DA REDE IFUSP

\begin{tabular}{|c|c|c|c|c|c|c|c|c|c|c|c|}
\hline \multirow[b]{2}{*}{ CATEGORIAS } & \multicolumn{4}{|c|}{ ALUNO } & \multicolumn{4}{|c|}{ DOCENTE } & \multirow{2}{*}{\begin{tabular}{|c|} 
PESQ \\
PD \\
\end{tabular}} & \multirow{2}{*}{$\frac{\text { FUNC }}{\text { GR }}$} & \multirow[t]{2}{*}{ TOTAL } \\
\hline & GR & ME & DR & ST & DR & PD & LD & ST & & & \\
\hline Continuar desempenho & 1 & 3 & 2 & 6 & - & - & - & - & - & - & 6 \\
\hline Contatar pessoas & - & - & 2 & 2 & - & - & - & - & - & - & 2 \\
\hline Desenvolver habilidade & $\cdot$ & - & 2 & 2 & 2 & - & - & 2 & - & 1 & 5 \\
\hline Compreender situação & - & 3 & 1 & 4 & 1 & 1 & - & 2 & 2 & - & 8 \\
\hline Alcançar objetivos & 1 & 1 & 3 & 5 & 4 & - & - & 4 & 2 & 4 & 15 \\
\hline Planejar, decidir & 1 & 1 & 1 & 3 & 1 & - & - & 1 & 2 & - & 6 \\
\hline Agilizar movimento & - & 1 & 3 & 4 & 1 & - & - & 1 & - & 1 & 6 \\
\hline Acalmar-se, relaxar & - & 1 & 2 & 3 & - & - & - & - & - & - & 3 \\
\hline Outros & - & 1 & 1 & 2 & 1 & - & - & 1 & - & - & 3 \\
\hline$S / R$ & - & - & 1 & 1 & 4 & - & - & 4 & 1 & 1 & 7 \\
\hline Sub-total & 3 & 11 & 18 & 32 & 14 & 1 & - & 15 & 7 & 7 & 61 \\
\hline Incompletos/Anulados & 2 & 2 & 7 & 11 & 8 & 1 & 3 & 12 & 2 & 1 & 26 \\
\hline TOTAL & 5 & 13 & 25 & 43 & 22 & 2 & 3 & 27 & 9 & 8 & 87 \\
\hline
\end{tabular}


Um quarto dos informantes espera obter dados que os auxiliem a alcançar seus objetivos e metas, solucionar o problema, finalizar o processo. Outra expectativa e quanto a compreender a situação em que se encontram, visualizar melhor seus contextos e/ou obter controle da situação $(13,1 \%)$.

Retomando que a maioria dos informantes utiliza as redes de maneira bastante pontual - apenas como um novo recurso de comunicação, quer como um local para se obter dados necessários a solução de problemas rápidos e cotidianos - e compreensíveis que suas expectativas se resumam a finalizar processo e obter controle e que isso ocorra entre os funcionários (57\%) e docentes (27\%), principalmente.

A expectativa "continuar desempenho" foi exclusivamente endereçada pelos alunos, sendo a mais mencionada entre eles (19\%). Pode-se inferir aqui que os alunos não estão trabalhando com necessidades pontuais, completas e possível de finalizar em si mesmas. Ao contrário, suas necessidades fazem parte de um todo, de um piano, onde cada lacuna deve ser ultrapassada individualmente de modo a se poder dar o passo seguinte.

\subsubsection{Estratégias Desenvolvidas pelo Usuário}

(cf. Tabela 5.2.5.1, AC \#07 - Apcndicc B)

Aqueles usuários que ativamente perseguem as respostas as suas necessidades de informação empregam vários tipos de estratégias. Foram utilizados ate 2 códigos para representá-las, utilizando de categorias definidas indutivamente.

A estratégia mais utilizada pela população em foco é a consulta aos pares, a profissionais e a pessoas com perfil condizente (26\%). Essa consulta é feita tanto por correio eletrônico (52\%) como através de grupos de discussão eletrônicos e pessoalmente / face-aface (ambos com 24\%). É a estratégia que os docentes mais lançam mão para solucionar suas dúvidas (29\%), em especial o contato face-a-face (60\%). Entre os funcionários e o alunado e também a mais utilizada (40\% e 25\% respectivamente), porém ambos com maior ênfase à consulta via correio eletrônico (50\% e 73\% respectivamente).

Desenvolver procedimentos por si mesmo, testar e comparar são outras estratégias empregadas pela população como um todo (18\%), tem sido muito utilizada pelos alunos, pouco pelos pesquisadores e, com baixa freqüência, entre docentes e funcionários. Talvez esse resultado demonstre que os alunos são os que mais tempo dedicam à rede, ou mais envolvimento e familiaridade tem com ela.

Consultar colegas, amigos e pessoas ao lado, por meio do correio eletrônico, ou facea-face, e consultar recursos disponíveis nas RE ou fora delas são estratégias que vem sendo desenvolvidas equitativamente pelos informantes $(17 \%$ de citações cada uma). O interessante e observar que $93 \%$ das consultas a colegas são feitas 
por correio eletrônico e apenas 7\% pessoalmente, e essa freqüência e exatamente oposta em relação aos recursos. Aqueles disponíveis via rede recebem 7\% de citações, e os externos a rede, 93\%. Esse resultado ratifica conclusões anteriores deste trabalho, em. que fica evidente o uso bastante intenso do correio eletrônico pelos informantes e o quase total desconhecimento e uso dos recursos disponíveis nas RE.

TABELA 5.2.5.1

\section{ESTRATÉGIAS EMPREENDIDAS $\times$ CLASSES DE USUÁRIOS DA REDE IFUSP}

\begin{tabular}{|c|c|c|c|c|c|c|c|c|c|c|c|}
\hline \multirow{2}{*}{ CATEGORIAS USUÁRIOS } & \multicolumn{4}{|c|}{ ALUNO } & \multicolumn{4}{|c|}{ DOCENTE } & \multirow{2}{*}{$\frac{\text { PESQ }}{\mathrm{PD}}$} & \multirow{2}{*}{$\frac{\text { FUNC }}{\mathrm{GR}}$} & \multirow[t]{2}{*}{ TOTAL } \\
\hline & GR & $\mathrm{ME}$ & $\mathrm{DR}$ & ST & DR & PD & LD & ST & & & \\
\hline $\begin{array}{l}\text { CONSULTAR A SI } \\
\text { PRÓPRIO }\end{array}$ & - & 1 & - & 1 & - & - & - & - & 1 & - & 2 \\
\hline $\begin{array}{l}\text { CONSULTAR COLEGAS } \\
\text { via email } \\
\text { face-a-face }\end{array}$ & $\overline{1}$ & - & $\begin{array}{l}1 \\
3\end{array}$ & $\begin{array}{l}1 \\
5\end{array}$ & 4 & - & - & - & i & 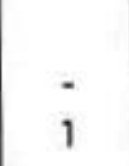 & $\begin{array}{c}1 \\
13\end{array}$ \\
\hline $\begin{array}{l}\text { CONSULTAR PARES } \\
\text { via email } \\
\text { face-a-face } \\
\text { via grupos discussão }\end{array}$ & $\begin{array}{l}- \\
-\end{array}$ & $\begin{array}{l}2 \\
- \\
1\end{array}$ & \begin{tabular}{l|}
6 \\
1 \\
1
\end{tabular} & $\begin{array}{l}8 \\
1 \\
2\end{array}$ & $\begin{array}{l}1 \\
3 \\
1\end{array}$ & $\begin{array}{l}- \\
-\end{array}$ & \begin{tabular}{l|l}
- & - \\
- & \\
-
\end{tabular} & $\begin{array}{l}1 \\
3 \\
1\end{array}$ & $\begin{array}{l}- \\
- \\
1\end{array}$ & $\begin{array}{l}2 \\
1 \\
1\end{array}$ & $\begin{array}{c}11 \\
5 \\
5\end{array}$ \\
\hline $\begin{array}{l}\text { CONSULTAR RECURSOS } \\
\text { via rede } \\
\text { fora da rede }\end{array}$ & - & $\begin{array}{l}2 \\
-\end{array}$ & $\begin{array}{l}4 \\
-\end{array}$ & $\begin{array}{l}6 \\
-\end{array}$ & $\begin{array}{l}3 \\
-\end{array}$ & - & - & $\begin{array}{l}3 \\
-\end{array}$ & 2 & $\begin{array}{l}2 \\
1\end{array}$ & $\begin{array}{c}13 \\
1\end{array}$ \\
\hline DESENVOLVER POR SI & 1 & 6 & 4 & 11 & - & 1 & -1 & 1 & 2 & 1 & 15 \\
\hline ESPERAR & 1 & - & 3 & 4 & - & - & - & - & - & - & 4 \\
\hline DESISTIR & - & - & 2 & 2 & 1 & - & - & 1 & - & 1 & 4 \\
\hline SOLUÇĀO ALTERNATIVA & - & 1 & 1 & 2 & 1 & - & - & 1 & 1 & - & 4 \\
\hline NENHUMA ESTRATÉGIA & - & 1 & - & 1 & - & - & - & - & - & - & 1 \\
\hline S/R & - & - & - & & 2 & - & - & 2 & 1 & - & 3 \\
\hline Sub-total & 3 & 15 & 26 & 44 & 16 & 1 & - & 17 & 11 & 10 & 82 \\
\hline Incompletos/Anulados & 2 & 2 & 7 & 11 & 8 & 1 & 3 & 12 & 2 & 1 & 26 \\
\hline TOTAL & 5 & 17 & 33 & 55 & 24 & 2 & 3 & 29 & 13 & 11 & 108 \\
\hline
\end{tabular}

OBS.: Questão múltipla 


\subsubsection{Completeza da Resposta Obtida pelo Usuário}

(cf. Tabela 5.2.6.1 e 5.2.6.2, AC \#08/1 AC \#09 - Apêndice B)

Nem sempre os usuários conseguem respostas as suas necessidades de informações. Dentre os que as obtém, diferentes são suas percepções quanto à completeza das respostas obtidas. Algumas são completas e outras parciais/ incompletas, portanto, insuficiente.

Dos 61 informantes, 36\% não obtêm as informações que precisam para sanar suas necessidades, 49\% conseguem obter respostas as suas questões e 15\% não fornecem avaliação de suas respostas. Dos que obtiveram retorno, 83\% as consideraram completas e suficientes para solucionar seus problemas e apenas 17\% julgaram-nas incompletas.

Frente a estes resultados, considera-se baixa a eficiência do sistema eletrônico. Embora a constatação anterior de que a grande maioria dos informantes desconhece os recursos disponíveis nas RE possa explicar a situação, obviamente que não a justifica. Tais fatos devem com certeza interferir na confiança dos informantes, bem como na credibilidade da própria rede.

TABELA 5.2.6.1

\section{COMPLETEZA DA RESPOSTA OBTIDA $X$ CLASSES DE USUÁRIOS DA REDE IFUSP}

\begin{tabular}{|c|c|c|c|c|c|c|c|c|c|c|c|}
\hline \multirow{2}{*}{ CATEGORIAS USUÁRIOS } & \multicolumn{4}{|c|}{ ALUNO } & \multicolumn{4}{|c|}{ DOCENTE } & \multirow{2}{*}{$\frac{\mathrm{PESQ}}{\mathrm{PD}}$} & \multirow{2}{*}{$\frac{\text { FUNC }}{\text { GR }}$} & \multirow[t]{2}{*}{ TOTAL } \\
\hline & GR & $\mathrm{ME}$ & DR & ST & DR & $\mathrm{PD}$ & LD & ST & & & \\
\hline Resposta NĀO obtida & - & 6 & 6 & 12 & 6 & - & - & 6 & 3 & 1 & 22 \\
\hline Resposta parcial & - & 1 & 2 & 3 & 1. & 1 & - & 2 & - & - & 5 \\
\hline Resposta completa & 3 & 3 & 9 & 15 & 3 & - & - & 3 & 1 & 6 & 25 \\
\hline$S / R$ & - & 1 & 1 & 2 & 4 & - & - & 4 & 3 & - & 9 \\
\hline Sub-total & 3 & 11 & 18 & 32 & 14 & 1 & - & 15 & 7 & 7 & 61 \\
\hline Incompletos/Anulados & 2 & 2 & 7 & 11 & 8 & 1 & 3 & 12 & 2 & 1 & 26 \\
\hline TOTAL & 5 & 13 & 25 & 43 & 22 & 2 & 3 & 27 & 9 & 8 & 87 \\
\hline
\end{tabular}


Quanto às classes de usuários, 40\% dos docentes, 37,5\% dos alunos e 25\% dos funcionários não recebem respostas. Dentre os pesquisadores em pós-doutoramento, foi muito grande a abstenção de respostas e a não-obtenção de respostas (43\% para ambos), sendo que $14 \%$ recebem resposta completa. Portanto, a categoria melhor sucedida e a dos funcionários, enquanto o oposto fica por conta dos pesquisadores e dos docentes.

Diferenciadas são as inferências que os informantes fazem ao avaliar a completeza da resposta obtida. A informação per si, a fonte que forneceu a resposta e as habilidades pessoais do próprio indivíduo são os critérios que tem norteado esse julgamento. Eles foram analisados conforme esquema indutivo apresentado no Apêndice B, AC \#09.

Dentre eles, o mais mencionado refere-se às peculiaridades da informação recebida (75\%). Atingir o objetivo, conseguir exatamente o esperado, solucionar parte do problema, fornecer a direção a ser seguida, possibilitar a economia de tempo e dinheiro são valores observados quando da avaliação da resposta recebida. Respostas que levaram o informante direto a solução dos problemas ficam identificadas como as mais completas (51\%). As dificuldades de uso das redes, a eficiência das redes e a confiabilidade nas pessoas uiliadas como fonte são critérios mencionados por $13 \%$ dos informantes. Somente na classe do alunado, a própria habilidade para resolver o problema de modo diferente aparece como indicativo de completeza.

O fato de algumas respostas não terem sido exatamente o que se esperava, mas ter fornecido a direção para a solução ou ter solucionado aquele problema específico embora não tenha colaborado para resolver a situação do usuário, são outros critérios empregados por 2,5\% destes informantes para avaliar o grau de completeza das respostas.

Dentre estes resultados, a distribuição pelas classes de usuários mostrou que 83\% dos funcionários estão preocupados e conseguem atingir os seus objetivos, solucionar problemas. O mesmo ocorre com 60\% dos alunos e com a totalidade dos pesquisadores em pós-doutoramento que obtiveram respostas (33,3\%). Não houve concentração relevante em nenhum dos critérios apontados pelos docentes. 
TABELA 5.2 .6 .2

AVALIAÇÃO DA COMPLETEZA DA RESPOSTA OBTIDA

$X$ CLASSES DE USUÁRIOS DA REDE IFUSP

\begin{tabular}{|c|c|c|c|c|c|c|c|c|c|c|c|}
\hline \multirow[b]{2}{*}{ CRITERIOS } & \multicolumn{4}{|c|}{ ALUNO } & \multicolumn{4}{|c|}{ DOCENTE } & \multirow{2}{*}{\begin{tabular}{|c|} 
PESQ \\
PD \\
\end{tabular}} & \multirow{2}{*}{\begin{tabular}{|c|} 
FUNC \\
GR \\
\end{tabular}} & \multirow[t]{2}{*}{ TOTAL } \\
\hline & GR & ME & DR & ST & DR & PD & LD & ST & & & \\
\hline \multicolumn{12}{|l|}{ QUANTO A INFORMAÇ̄O } \\
\hline Atinge o objetivo & $\cdot$ & 2 & 7 & 9 & 1 & $\cdot$ & $\cdot$ & 1 & 1 & 5 & 16 \\
\hline Resolve parte do problema & $\cdot$ & - & - & - & - & 1 & $\cdot$ & 1 & - & - & 1 \\
\hline Resposta pré-determinada & 2 & 1 & $\cdot$ & 3 & $\cdot$ & $\cdot$ & $\cdot$ & $\cdot$ & - & - & 3 \\
\hline $\begin{array}{l}\text { QUANTO A HABILIDADE } \\
\text { PESSOAL }\end{array}$ & & & & & & & & & & & \\
\hline Desconhece alternativas & - & 1 & 1 & 2 & - & - & - & - & $\cdot$ & - & 2 \\
\hline \multirow{2}{*}{\multicolumn{12}{|c|}{$\begin{array}{l}\text { QUANTO A FONTE DE } \\
\text { INFORMAÇÃO }\end{array}$}} \\
\hline & & & & & & & & & & & \\
\hline Eficiència das RE & 1 & - & - & 1 & 1 & - & - & 1 & - & - & 2 \\
\hline Dificuldade no uso das RE & $\cdot$ & - & - & - & 1 & - & - & 1 & - & - & 1 \\
\hline Confiabilidade na pessoa & $\cdot$ & - & 1 & 1 & - & - & - & - & - & 1 & 2 \\
\hline S/R & $\cdot$ & 1 & 2 & 3 & 5 & - & - & 5 & 3 & - & 11 \\
\hline Sub-total & 3 & 5 & 12 & 20 & 8 & 1 & $\cdot$ & 9 & 4 & 6 & 39 \\
\hline Necessidade NĀO solucionad & $\cdot$ & 6 & 6 & 12 & 6 & $\cdot$ & $\cdot$ & 6 & 3 & 1 & 22 \\
\hline Incompletos/Anulados & 2 & 2 & 7 & 11 & 8 & 1 & 3 & 12 & 2 & 1 & 26 \\
\hline TOTAL & 5 & 13 & 25 & 43 & 22 & 2 & 3 & 27 & 9 & 8 & 87 \\
\hline
\end{tabular}




\subsubsection{Satisfação com a Resposta Obtida}

(cf. Tabela 5.2.7.1, e 5.2.7.2 e AC if 08/2 - Apêndice B)

Do mesmo modo que usuários visualizam a completeza das respostas obtidas diferentes entre si, também seu nível de satisfação varia.

Descontando as questões cujas respostas não foram obtidas pelos informantes e aquelas apresentadas em branco no instrumento de coleta de dados, totalizaram 30 respostas. Dessas, 70\% representaram máxima satisfação aos informantes, 24\% se sentiram regularmente satisfeitos e apenas 3\% tiveram mínima satisfação.

TABELA 5.2.7.1

\section{SATISFAÇÃO COM A RESPOSTA OBTIDA} $X$ CLASSES DE USUÁRIOS DA REDE IFUSP

\begin{tabular}{|c|c|c|c|c|c|c|c|c|c|c|c|}
\hline \multirow[b]{2}{*}{ CATEGORIAS } & \multicolumn{4}{|c|}{ ALUNO } & \multicolumn{4}{|c|}{ DOCENTE } & \multirow{2}{*}{$\frac{\text { PESQ. }}{\mathrm{PD}}$} & \multirow{2}{*}{$\begin{array}{c}\text { FUNC. } \\
\text { GR } \\
\end{array}$} & \multirow[t]{2}{*}{ TOTAL } \\
\hline & GR & ME & $\mathrm{DR}$ & ST & DR & PD & LD & ST & & & \\
\hline NENHUMA & - & - & - & - & - & - & - & - & - & - & \\
\hline MINIIMA & 1 & - & - & 1 & - & - & - & - & - & - & 1 \\
\hline REGULAR & - & 1 & 2 & 3 & 1 & 1 & - & 2 & 1 & 2 & 8 \\
\hline MÁXIMA & 2 & 4 & 8 & 14 & 3 & - & - & 3 & - & 4 & 21 \\
\hline$S / R$ & - & - & 2 & 2 & 4 & - & - & 4 & 3 & - & 9 \\
\hline Sub-total & 3 & 4 & 12 & 20 & 8 & 1 & - & 9 & 4 & 6 & 39 \\
\hline Necessidades NĀO solucio- & & & & & & & & & & & \\
\hline nadas * & - & 6 & 6 & 12 & 6 & - & - & 6 & 3 & 1 & 22 \\
\hline Incompletos/Anulados & 2 & 2 & 7 & 11 & 8 & 1 & 3 & 12 & 2 & 1 & 26 \\
\hline TOTAL & 5 & 13 & 25 & 43 & 22 & 2 & 3 & 27 & 9 & 8 & 87 \\
\hline
\end{tabular}

* refere-se às questões que os usuários não obtém respostas 
Um estudo sobre níveis de satisfação para cada classe de usuários demonstra que $82,5 \%$ do alunado obtêm máxima satisfação com a resposta colhida, contra 12\% para regular e 6\% para mínima. Dentre os docentes, 60\% alcançam satisfação máxima e 40\% regular. Os funcionários apresentaram $67 \%$ de respostas com satisfação máxima e o restante e regular. $E$ entre os pesquisadores, apenas um obteve resposta e esta foi regular. Conclui-se que 0 alunado é o que tem obtido maiores retornos quando buscando informação nas redes.

Quanto à satisfação dos usuários frente às informações obtidas, os mesmos critérios de avaliação da completeza são utilizados (AC \#09, Apêndice B).

Também para a avaliação da satisfação os informantes se valem mais das particularidades da informação recebida como resposta (54\%), em especial com aquelas que os levaram a atingir seus objetivos (28\%). O fato de a resposta facilitar a solução do problema foi motivo de satisfação para 13\% dos usuários.

Muito embora $41 \%$ dos informantes tenham considerado a resposta completa por ter atingido o objetivo, apenas $26 \%$ se sentiram muito satisfeitos com isso. Esses resultados reafirmam a análise feita por LANCASTER (apud FIGUEIREDO, 1979), enfatizando que os usuários medem sua satisfação com o critério do seu próprio conhecimento sobre as disponibilidades do sistema. Desta forma, conclui-se que como a rede vem sendo mal conhecida, inexplorada e subutilizada, o julgamento fica com a objetividade prejudicada. Por outro lado, embora algumas respostas sejam obtidas por completo e de forma suficiente, não são consideradas satisfatórias por $5 \%$ porque sua obtenção não foi simples. Para 2,5\% dos informantes, o motivo alegado é a dificuldade no uso das RE, e outro tanto (2,5\%) porque não atingiu o objetivo esperado. Outros critérios de menor representatividade podem ser depreendido da tabela a seguir. 
TABELA 5.2 .7 .2

\section{AVALIAÇĀO DA SATISFAÇĀO COM A RESPOSTA OBTIDA $X$ CLASSES DE USUARIOS DA REDE IFUSP}

\begin{tabular}{|c|c|c|c|c|c|c|c|c|c|c|c|}
\hline \multirow[t]{2}{*}{ DESCRIÇĀO } & \multicolumn{4}{|c|}{ ALUNO } & \multicolumn{4}{|c|}{ DOCENTE } & \multirow{2}{*}{\begin{tabular}{|c|} 
PESQ \\
PD \\
\end{tabular}} & \multirow{2}{*}{\begin{tabular}{|c|} 
FUNC \\
GR
\end{tabular}} & \multirow[t]{2}{*}{ TOTAL } \\
\hline & GR & ME & DR & ST & DR & PD & LD & ST & & & \\
\hline \multicolumn{12}{|l|}{ QUANTO À INFORMAÇĀO } \\
\hline Atinge o objetivo & 1 & - & 3 & 4 & 3 & - & - & 3 & - & 4 & 11 \\
\hline Resolve parte do problema & - & - & 1 & 1 & - & 1 & - & 1 & - & - & 2 \\
\hline Fornece a direção & - & 1 & - & 1 & - & - & - & - & - & - & 1 \\
\hline Simplifica a solução & - & 1 & 3 & 4 & - & - & - & - & - & 1 & 5 \\
\hline Economiza tempo & - & 1 & 1 & 2 & - & - & - & - & - & - & 2 \\
\hline \multirow{2}{*}{\multicolumn{12}{|c|}{$\begin{array}{l}\text { QUANTO Ả HABILIDADE } \\
\text { PESSOAL }\end{array}$}} \\
\hline & & & & & & & & & & & \\
\hline Desconhece alternativas & 1 & - & - & 1 & - & - & - & - & - & - & 1 \\
\hline Compreende a situação & - & - & 2 & 2 & - & - & - & - & - & - & 2 \\
\hline \multirow{2}{*}{\multicolumn{12}{|c|}{$\begin{array}{l}\text { QUANTO Ã FONTE DE } \\
\text { INFORMACุĀO }\end{array}$}} \\
\hline & & & & & & & & & & & \\
\hline Eficiência das RE & - & - & - & - & - & - & - & - & 1 & - & 1 \\
\hline Dificuldade no uso das RE & - & - & - & - & 1 & - & - & 1 & - & - & 1 \\
\hline Confiabilidade na pessoa & - & 1 & - & 1 & - & - & - & - & - & 1 & 2 \\
\hline$S / R$ & 1 & 1 & 2 & 4 & 4 & - & - & 4 & 3 & - & 11 \\
\hline Sub-total & 3 & 5 & 12 & 20 & 8 & 1 & - & 9 & 4 & 6 & 39 \\
\hline Necessidade NÄO solucionad & - & 6 & 6 & 12 & 6 & - & - & 6 & 3 & 1 & 22 \\
\hline Incompletos/Anulados & 2 & 2 & 7 & 11 & 8 & 1 & 3 & 12 & 2 & 1 & 26 \\
\hline TOTAL & 5 & 13 & 25 & 43 & 22 & 2 & 3. & 27 & 9 & 8 & 87 \\
\hline
\end{tabular}




\subsubsection{Esforço Dispendido na Localização da Informação}

(cf. Tabela 5.2.8.1, AC \# 08/3 - Apêndice B)

Outra análise desenvolvida reside na importância dada pelos usuários aquela necessidade colocada em forma de questão. Essa importância e observada operacionalmente em função do esforço que os informantes dispendem para obter respostas as suas questões.

Dentre as categorias apresentadas aos usuários para que indicassem quanto esforço tinham dedicado aquela necessidade em particular, observou-se que o maior número deles considera seus esforços como regulares (41\%) e mínimos (33\%). Dentre as classes de usuários em particular, depreende-se que (a) 40\% dos docentes indicaram mínimo esforço e 33\% regular; (b) $37,5 \%$ dos alunos, mínimo esforço e 34\% regular; (c) $43 \%$ dos pesquisadores em pós-doutoramento se empenharam regularmente; (d) $86 \%$ dos funcionários, esforço regular.

Interessante observar que embora no cômputo geral os pesquisadores tenham se empenhado mais que os docentes e alunos, foram eles que apresentaram o mais baixo índice na obtenção de respostas. For outro lado, os mais empenhados são os funcionários, talvez pela natureza de suas atividades.

TABELA 5.2.8.1

\section{ESFORÇO DISPENDIDO NA LOCALIZAÇĀO DA RESPOSTA}

$x$ CLASSES DE USUÁRIOS DA REDE IFUSP

\begin{tabular}{|c|c|c|c|c|c|c|c|c|c|c|c|}
\hline \multirow{2}{*}{ CATEGORIAS USUÁRIOS } & \multicolumn{4}{|c|}{ ALUNO } & \multicolumn{4}{|c|}{ DOCENTE } & \multirow{2}{*}{\begin{tabular}{|c|} 
PESQ. \\
PD \\
\end{tabular}} & \multirow{2}{*}{\begin{tabular}{|c|} 
FUNC. \\
GR \\
\end{tabular}} & \multirow[t]{2}{*}{ TOTAL } \\
\hline & GR & $\mathrm{ME}$ & DR & ST & DR & PD & LD & ST & & & \\
\hline NENHUM & - & - & - & - & 1 & - & - & 1 & - & - & 1 \\
\hline MINIMO & 1 & 2 & 9 & 12 & 5 & 1 & - & 6 & 1 & 1 & 20 \\
\hline REGULAR & 2 & 6 & 3 & 11 & 5 & - & - & 5 & 3 & 6 & 25 \\
\hline GRANDE & - & 3 & 3 & 6 & 1 & - & - & 1 & 1 & - & 8 \\
\hline$S / R$ & - & - & 3 & 3 & 2 & - & - & 2 & 2 & - & 7 \\
\hline Sub-total & 3 & 11 & 18 & 32 & 14 & 1 & - & 15 & 7 & 7 & 61 \\
\hline Incompletos/Anulados & 2 & 2 & 7 & 11 & 8 & 1 & 3 & 12 & 2 & 1 & 26 \\
\hline TOTAL & 5 & 13 & 25 & 43 & 22 & 2 & 3 & 27 & 9 & 8 & 87 \\
\hline
\end{tabular}




\subsubsection{Recursos Informacionais Utilizados}

(cf. Tabela 5.2.9.1, CA \#11 - Apêndice B)

Em suas tentativas de localizar a informação necessária, os pesquisados buscaram apoio junto a vários recursos informacionais $(\mathrm{RI})^{6}$.

Esses RI, classificados indutivamente, foram agrupados em contatos informais, recursos via rede, serviços via rede e serviços fora da rede. O grupo mais procurado e o dos recursos existentes na rede (39\%), sendo que dentre estes, o correio eletrônico fica em primeiro lugar (37\%), seguido do FTP (25,5\%). O help online e FAQ e o Finger coincidem no terceiro lugar dentre os recursos via RE mais utilizados, com 12\% cada. A seguir vem o Netfind (7\%) e, por último, o Talk e o WAIS (2\% cada).

O segundo grupo de recursos, intitulado "contatos informais", foi utilizado $33 \%$ das vezes. Como já mostrado antes, os colegas são os mais procurados $(32,4 \%)$, tanto no geral como entre os docentes e funcionários. Em seguida, vêm as assistências técnicas do Vax e/ou CCE (19\%) e profissionais diversos (16\%). Consultar a si próprio recebe 5\% de citações, e recorrer a alunos de pós-graduação também é mencionado $5 \%$ das vezes, porém são utilizados exclusivamente pelos docentes.

Ainda $22 \%$ dos informantes mencionam, de maneira geral, que se utilizam de contatos informais. $\mathrm{Na}$ análise anteriormente apresentada das estratégias empreendidas, é evidenciada a procura de auxílio junto a colegas, através do contato pessoal, por grande número de informantes. O contato por email também é bastante utilizado.

O terceiro grupo de RI utilizados recai nos serviços disponíveis nas RE com $23 \%$ do total. Dentre eles, o servidor WWW é o mais procurado (27\%), seguido dos bancos de dados e catálogos de bibliotecas (23\%). O Servidor NEWS do VAX, classificado em conjunto com o USENET, recebe $15 \%$ de citações.

Relembramos que a maioria dos usuários desconhece ou nunca utiliza grande parte dos serviços existentes nas RE. Parece pois relevante observar que os poucos que os conhecem estão os utilizando bastante na busca de informações.

Apenas 4,5\% dos informantes (sendo esses exclusivamente alunos e funcionários) mencionam o uso de recursos e serviços fora das redes, entre eles editoras e livrarias (60\%), revistas de informática (20\%) e o telefone (20\%). Logo, a postura desses informantes parece ser a de buscar soluções para suas necessidades dentro da própria rede.

6 Recurso informacional e compreendido como "quaisquer instituições, serviços, fontes bibliográficas ou indivíduos, capazes de dar respostas científicas, técnicas e/ou utilitárias para a comunidade" (FERREIRA, 1989, p. 72). 
Entre as classes de usuários, os recursos mais utilizados pelos alunos são os disponíveis via RE (45,5\%), seguido dos contatos informais (31,9\%), serviço via rede (20\%) e, por último, os fora da rede (3,2\%). Já os docentes buscam mais apoio junto aos contatos informais (40\%), sendo o segundo lugar para os recursos e serviços disponíveis nas RE (com $30 \%$ cada). A grande maioria dos pesquisadores em pós-doutoramento (60\%) utiliza os serviços via rede, e o restante se divide, equitativamente, entre o contato informal e os recursos da RE (20\% cada).

Finalmente, para os funcionários o recurso mais procurado e o contato informal (35\%), seguido pelos recursos via RE (30\%), servos via RE (20\%) e, por último, os serviços fora da RE (15\%). 
TABELA 5.2.9.1

RECURSOS INFORMACIONAIS

$X$ CLASSES DE USUÁRIOS DA REDE IFUSP

\begin{tabular}{|c|c|c|c|c|c|c|c|c|c|c|c|}
\hline \multirow{2}{*}{$\begin{array}{ll}\text { CATEGORIAS } & \\
\end{array}$} & \multicolumn{4}{|c|}{ ALUNO } & \multicolumn{4}{|c|}{ DOCENTE } & \multirow{2}{*}{$\frac{\mathrm{PESQ}}{\mathrm{PD}}$} & \multirow{2}{*}{\begin{tabular}{|c|} 
FUNC. \\
GR \\
\end{tabular}} & \multirow[t]{2}{*}{ TOTAL } \\
\hline & $\overline{G R}$ & $\mathrm{ME}$ & $\overline{D R}$ & ST & $\overline{D R}$ & PD & LD & ST & & & \\
\hline \multicolumn{12}{|l|}{ CONTATOS INFORMAIS } \\
\hline Em geral & - & 1 & 4 & 5 & 1 & 1 & - & 2 & - & 1 & 8 \\
\hline Própria pessoa & - & - & 1 & 1 & - & - & - & - & - & 1 & 2 \\
\hline Colegas & - & 2 & 1 & 3 & 4 & - & - & 4 & 3 & 2 & 12 \\
\hline Alunos pós-graduaçâo & - & - & - & - & 2 & - & - & 2 & - & - & 2 \\
\hline Profissionais diversos & - & 1 & 4 & 5 & - & - & . &. & - & 1 & 6 \\
\hline \multicolumn{12}{|l|}{ Postmaster / Assistência } \\
\hline Técnica & - & - & 5 & 5 & - & - & - & $\cdot$ & - & 2 & 7 \\
\hline \multicolumn{12}{|l|}{ RECURSOS DA REDE } \\
\hline Help online, FAQ & - & 2 & 1 & 3 & - & - & - & - & 1 & 1 & 5 \\
\hline Correio eletrônico & - & 3 & 8 & 11 & 2 & - & - & 2 & 1 & 2 & 16 \\
\hline FTP & 1 & 2 & 2 & 5 & 1 & 1 & - & 2 & 2 & 2 & 11 \\
\hline Talk & - & 1 & - & 1 & - & - & - & - & - & - & 1 \\
\hline Finger & - & 1 & - & 1 & - & - & - & - & - & - & 1 \\
\hline \multicolumn{12}{|l|}{ SERVIÇOS VIA REDE } \\
\hline Archie & 1 & - & 1. & 2 & 1 & 1 & - & 2 & - & 1 & 5 \\
\hline Netfind & - & 2 & 1 & 3 & - & - & - & - & - & - & 3 \\
\hline WAIS & - & - & 1 & 1 & - & - & - & - & - & - & 1 \\
\hline Repositórios públicos & - & - & - & - & 1 & - & - & 1 & 1 & - & 2 \\
\hline Banco dados/catálogos & - & 1 & - & 1 & 2 & - & - & 2 & 2 & 1 & 6 \\
\hline Livrarias, editoras & 1 & - & - & 1 & - & - & - & - & - & 1 & 2 \\
\hline WWW & - & 1 & 1 & 2 & 2 & - & - & 2 & 2 & 1 & 7 \\
\hline Gopher & - & - & 1 & 1 & - & - & - & - & - & - & 1 \\
\hline Listas de discussão & - & - & 1 & 1 & - & - & - & - & 1 & - & 2 \\
\hline BBS (Pré-print) & - & - & 1 & 1 & 1 & - & - & 1 & - & - & 2 \\
\hline News, Vax/USENET & 1 & 2 & - & 3 & - & - & -1 & - & - & 1 & 4 \\
\hline \multicolumn{12}{|l|}{ SERVIÇOS FORA DA RE } \\
\hline Livrarias, editoras & - & - & 1 & 1 & - & - & - & - & - & 2 & 3 \\
\hline Rev. de Informática & - & - & - & . & - & - & - &. & - & 1 & 1 \\
\hline Telefone & - & - & 1 & 1 & - & - & - & - & - & - & 1 \\
\hline TOTAL & $\overline{4}$ & 19 & 35 & 58 & 17 & 3 & - & 20 & 13 & 20 & 111 \\
\hline
\end{tabular}

OBS.: questão múltipla 


\subsubsection{Fontes de Informação}

(cf. Tabela 5.2.10.1, CA \#10 - Ap6ndice B)

Embora comprovado que vários recursos informacionais tenham sido utilizados, observa-se que das 61 questões colocadas pelos usuários, 49\% conseguem respostas. Portanto, e importante apresentar aqueles recursos que realmente se transformam em fontes de informação, ou seja, que de algum modo auxiliam o usuário a solucionar seu problema. Contatos pessoais contribuem com $67 \%$ e recursos da rede com $23 \%$.

TABELA 5.2.10.1

FONTES DE INFORMAÇĀO

$X$ CLASSES DE USUÁRIOS DA REDE IFUSP

\begin{tabular}{|c|c|c|c|c|c|c|c|c|c|c|c|}
\hline \multirow[b]{2}{*}{ CATEGORIAS } & \multicolumn{4}{|c|}{ ALUNO } & \multicolumn{4}{|c|}{ DOCENTE } & \multirow{2}{*}{\begin{tabular}{|c|} 
PESQ \\
$P D$ \\
\end{tabular}} & \multirow{2}{*}{\begin{tabular}{|c|} 
FUNC. \\
GR \\
\end{tabular}} & \multirow[t]{2}{*}{ TOTAL } \\
\hline & GR & $\mathrm{ME}$ & $\mathrm{DR}$ & ST & DR & $\mathrm{PD}$ & LD! & ST & & & \\
\hline PRÓPRIA PESSOA & - & 1 & - & 1 & - & 1 & - & 1 & - & 1 & 3 \\
\hline PESSOAS EM GERAL & 1 & 1 & 5 & 7 & - & - & - & - & - & 2 & 9 \\
\hline AUTORIDADE NA ÁREA & - & 1 & 4 & 5 & 1 & - & - & 1 & - & 2 & 8 \\
\hline RECURSOS DA REDE & 1 & - & 1 & 2 & 3 & - & - & 3 & 1 & 1 & 7 \\
\hline OUTRAS & 1 & 2 & - & 3 & - & - & - & - & - & - & 3 \\
\hline Sub-total & 3 & 5 & 10 & 18 & 4 & 1 & - & 5 & 1 & 6 & 30 \\
\hline Em branco & - & - & 2 & 2 & 4 & - & - & 4 & 3 & - & 9 \\
\hline Necessidade NÃO solucio- & & & & & & & & & & & \\
\hline nada & - & 6 & 6 & 12 & 6 & - & - & 6 & 3 & 1 & 22 \\
\hline Sub-total & 3 & & 18 & 32 & 14 & 1 & - & 15 & - & - & 61 \\
\hline Incompletos/Anulados & 2 & 2 & 7 & 11 & 8 & 1 & 3 & 12 & 2 & 1 & 26 \\
\hline TOTAL & 5 & 13 & 25 & 43 & 22 & 2 & 3 & 27 & 9 & 8 & 87 \\
\hline
\end{tabular}




\section{ANÁLISE III}

\subsection{NECESSIDADES DE INFORMAÇÃO NÃO SOLUCIONADAS}

\subsubsection{Contexto de Utilização das RE}

(cf. Tabela 5.3.1.1, AC \#03 - Apêndice B)

Dentre os quatro contextos anteriormente delimitados que vem levando os usuários a utilizar as RE, os que apresentam maior niimero de necessidades não satisfeitas são tanto as de busca de informações técnico-científicas como as de simples uso dos serviços básicos (email, FTP e Telnet), com 32\% cada. A busca de soluções para problemas imediatos fica em segundo lugar (23\%) e aquisição de conhecimento sobre as RE em último (14\%).

Comparando a Tabela 5.3.1.1 com a Tabela 5.2.1.1, observa-se que dentre todos os usuários que buscam a rede com o fim único de comunicação, 25\% não solucionam suas necessidades de informação. Este é um número bastante expressivo, devido à experiência que os usuários demonstram ter no uso dos serviços básicos das RE.

Já quanto aos usuários buscando informações na rede, 32\% são mal sucedidos, o que parece razoável que ocorra, tendo em vista o grande desconhecimento apresentado pelos informantes quanto aos serviços específicos para recuperação de informação disponíveis nas RE. Desconhecimento que não é de todo estranho. Em trabalho realizado em 1967, CARTER (apud FIGUEIREDO, 1985), tratando da qualidade da informação, acusava que "a quantidade de informação disponível só pode ser dirigida através de um serviço que se preocupe em melhorar sua qualidade. Os sistemas podem fazer isso, condensando ou pré-selecionando informações relevantes e descartando as não-relevantes". Essa realidade num ambiente eletrônico fica agravada.

A busca de soluções para problemas imediatos apresenta $22 \%$ de questões não respondidas, enquanto a aquisição de conhecimento, 60\%. Este último, apresenta-se como o mais alto fndice de insucesso dentre as situações estudadas. Não causa demasiada estranheza, uma vez que informantes incluídos nessa categoria de situação são os que ainda agem de modo incipiente em relação as RE e suas reais possibilidades. Estão iniciando a busca de maiores informações sobre as RE, suas vantagens e benefícios quando utilizadas profissionalmente. Tratam-se de pessoas que claramente mostram maiores dificuldades e barreiras em resolver problemas quando da utilização das RE. 
TABELA 5.3.1.1

CONTEXTO DE UTILIZAÇÃO DAS REDES ELETRÔNICAS

$X$ CLASSES DE USUÁRIOS DA REDE IFUSP

(necessidades de informaçăo năo solucionadas)

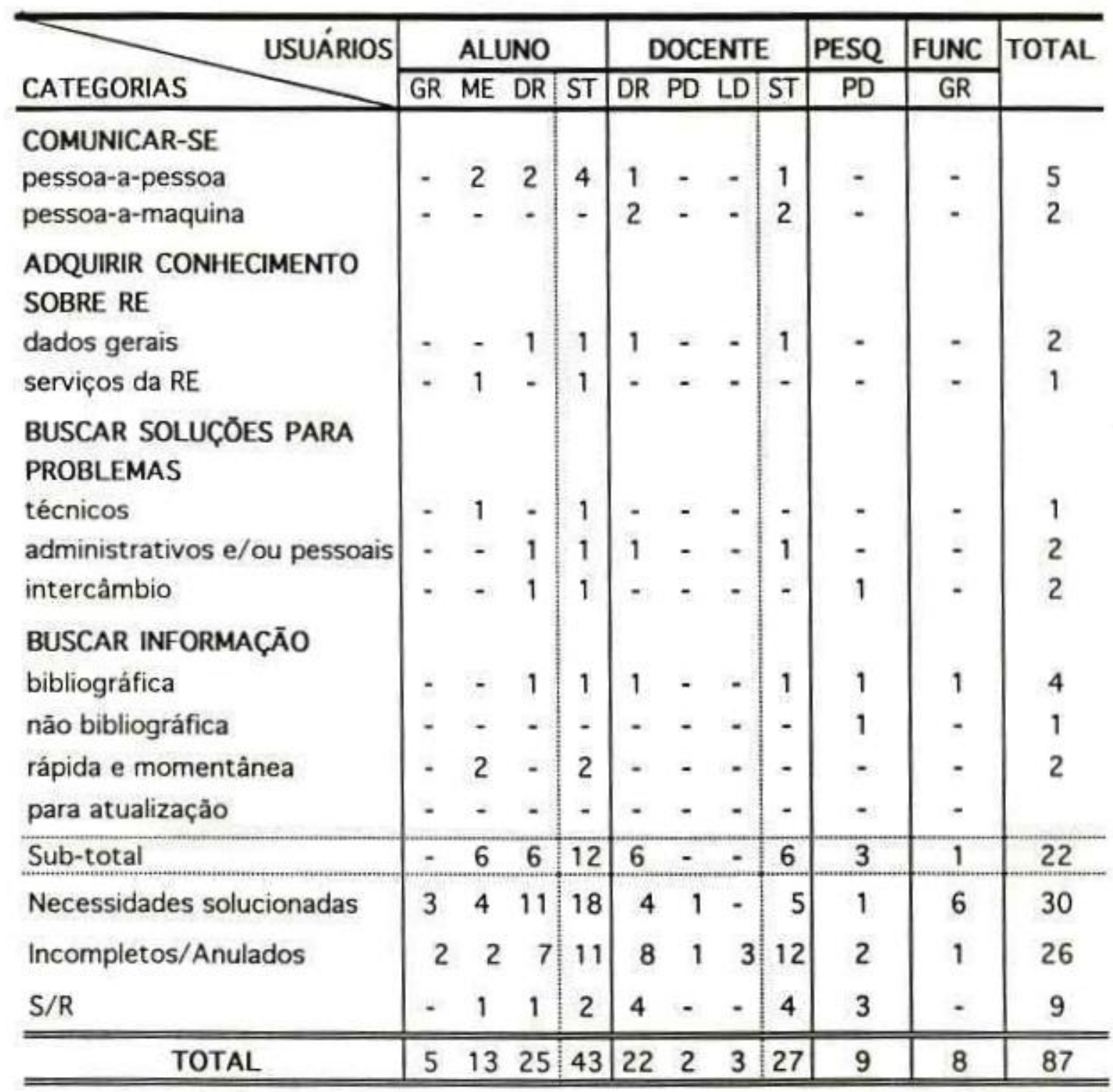


5.3.2 Natureza das Questões do Usuário - necessidades de informação não solucionadas

(cf.Tabela5.3.2.1, AC \#04 - Apêndice)

A natureza das necessidades de informação não-satisfeitas também é analisada conforme as categorias estabelecidas no esquema 5W. A maior incidência de questões não respondidas corresponde aquelas em que os informantes estão buscando adquirir habilidades quanto a procedimentos e normas (27\%). Questões de identificação (O que) e de explicações (For que) vêm em segundo lugar, com 18\% de insucesso cada uma. As categorias "Quem" e "Onde" recebem 9\%, e "Quando" 4,5\%. A categoria "Outros", envolvendo questões do tipo "Será?", ocupa 14\% das respostas não obtidas.

Um estudo destas categorias junto ao total de questões colocadas pelos informantes (cf. Tabela 5.2.2.1) mostra que 75\% das necessidades de explicações, razões e causas (categoria For que) não são solucionadas. Da busca de identificação de pessoa(s) que podem solucionar o problema, 40\% não encontram respostas. A identificação das diferentes possibilidades de informação disponíveis nas RE fica sem solução em $30 \%$ dos casos. A busca de procedimentos é mal sucedida em 28,5\% das vezes, a localização espacial da informação deixa $18 \%$ dos informantes sem respostas e, finalmente, a localização temporal não é solucionada em $33 \%$ dos casos.

\section{TABELA 5.3.2.1}

NATUREZA DA QUESTÃO DO USUÁRIO

$X$ CLASSES DE USUÁRIOS DA REDE IFUSP

(necessidades de informaçăo năo solucionadas)

\begin{tabular}{|c|c|c|c|c|c|c|c|c|c|c|c|}
\hline \multirow{2}{*}{$\begin{array}{ll}\text { CATEGORIAS } & \text { USUARIOS } \\
\end{array}$} & \multicolumn{4}{|c|}{ ALUNO } & \multicolumn{4}{|c|}{ DOCENTE } & \multirow{2}{*}{\begin{tabular}{|c|} 
PESQ \\
PD \\
\end{tabular}} & \multirow{2}{*}{\begin{tabular}{|c|} 
FUNC \\
GR \\
\end{tabular}} & \multirow[t]{2}{*}{ TOTAL } \\
\hline & GR & $\mathrm{ME}$ & $\overline{D R}$ & ST & $D R$ & $P D$ & $\overline{L D}$ & ST & & & \\
\hline O QUË & - & 3 & 1 & 4 & - & - & - & - & - & - & 4 \\
\hline QUEM & - & - & 1 & 2 & - & - & - & - & 1 & - & 2 \\
\hline ONDE & - & - & - & - & 2 & - & - & 2 & - & - & 2 \\
\hline QUANDO & - & - & - & 1 & - & - & - & - & 1 & - & 1 \\
\hline сомо & - & 1 & 3 & 4 & 1 & - & - & 1 & 1 & - & 6 \\
\hline POR QUE & - & 2 & - & 2 & 2 & - & - & 2 & - & - & 4 \\
\hline DUTROS & - & - & 1 & 1 & 1 & - & - & 1 & - & 1 & 3 \\
\hline Sub-total & - & 6 & 6 & 12 & 6 & - & - & 6 & 3 & 1 & 22 \\
\hline Necessidades solucionadas & 3 & 4 & 11 & 18 & 4 & 1 & - & 5 & 1 & 6 & 30 \\
\hline ncompletos/Anulados & 2 & 2 & 7 & 11 & 8 & 1 & 3 & 12 & 2 & 1 & 26 \\
\hline$S / R$ & - & 1 & 1 & 2 & 4 & - & - & 4 & 3 & - & 9 \\
\hline TOTAL & 5 & 13 & 25 & 43 & 22 & 2 & 3 & 27 & 9 & 8 & 87 \\
\hline
\end{tabular}




\subsubsection{Foco das Questões do Usuário - necessidades de informação não solucionadas}

(cf. Tabela 5.3.3.1, AC \#05- Apêndice B)

Dentre as 22 questões não respondidas, observa-se que $32 \%$ correspondem a "Situação 1", 23\% as "Situações 2 e 3" cada uma. A categoria "objeto/coisa" corresponde a $14 \%$ e "outras pessoas" a $9 \% \%$.

Comparando esses resultados com o total das questões apresentadas na tabela 5.2.3.1, verifica-se que $67 \%$ das questões envolvendo a Situação 3 (recursos da rede) não são solucionadas. Como também não tiveram solução: 54\% da Situação 1 (genérica) e 45\% da Situação 2 (a própria rede). A somatória total de necessidades de informação tendo como foco uma "situação" (46\%) não é atendida. Quanto ao foco "objeto / coisa", 60\% das questões ficam sem respostas e para o foco "outras pessoas", 40\% não se solucionam. As questões enfocando a própria pessoa são resolvidas totalmente.

\section{TABELA 5.3.3.1}

\section{FOCO DA QUESTÃO DO USUÁRIO \\ $X$ CLASSES DE USUÁRIOS DA REDE IFUSP \\ (necessidades de informaçăo năo solucionadas)}

\begin{tabular}{|c|c|c|c|c|c|c|c|c|c|c|c|}
\hline \multirow{2}{*}{ CATEGORIAS USUÁRIOS } & \multicolumn{4}{|c|}{ ALUNO } & \multicolumn{4}{|c|}{ DOCENTE } & \multirow{2}{*}{\begin{tabular}{|c|} 
PESQ \\
PD
\end{tabular}} & \multirow{2}{*}{\begin{tabular}{|c|} 
FUNC. \\
GR
\end{tabular}} & \multirow[t]{2}{*}{ TOTAL } \\
\hline & $\overline{G R}$ & $\overline{M E}$ & $\overline{D R}$ & ST & $\overline{D R}$ & $\overline{P D}$ & $\overline{L D}$ & ST & & & \\
\hline PRÓPRIA PESSOA & - & - & $\cdot$ & - & - & - & - & - & - & - & \\
\hline OUTRAS PESSOAS & - & - & 1 & 1 & - & - & - & - & 1 & - & 2 \\
\hline OBJETO/COISA & - & 1 & - & 1 & 1 & - & - & 1 & - & 1 & 3 \\
\hline SITUAÇĀO 1 & - & 1 & 5 & 6 & 1 & - & - & 1 & - & - & 7 \\
\hline SITUAÇĀO 2 & - & 3 & - & 3 & 1 & - & - & 1 & 1 & - & 5 \\
\hline SITUAÇĀO 3 & - & 1 & - & 1 & 3 & - & - & 3 & 1 & - & 5 \\
\hline Sub-total & - & 6 & 6 & 12 & 6 & - & - & 6 & 3 & 1 & 22 \\
\hline Necessidades solucionadas & 3 & 4 & 11 & 18 & 4 & 1 & - & 5 & 1 & 6 & 30 \\
\hline Incompletos/Anulados & 2 & 2 & 7 & 11 & 8 & 1 & 3 & 12 & 2 & 1 & 26 \\
\hline$S / R$ & - & 1 & 1 & 2 & 4 & - & - & 4 & 3 & - & 9 \\
\hline TOTAL & 5 & 13 & 25 & 43 & 22 & 2 & 3 & 27 & 9 & 8 & 87 \\
\hline
\end{tabular}




\subsubsection{Expectativa de Uso da Informação - necessidades de informação não solucionadas}

(cf. Tabela 5.3.4.1, AC \#06 - Apêndice B)

Identificam-se que as maiores expectativas frustradas referem-se aqueles informantes que buscam alcançar seus objetivos e aos que almejam agilizar seus movimentos (23\% cada). A necessidade de obter dados que propiciem condições de planejamento e tomadas de decisões e mal sucedida entre $14 \%$ dos informantes sem respostas. As categorias "continuar desempenho", "desenvolver habilidades" e "compreender a situação" tem resultados semelhantes com 9\% cada. A vontade de "acalmar-se / relaxar-se" fica em último com $4,5 \%$.

Comparando estes resultados com os detectados no global das questões (cf. Tabela 5.2.4.1), conclui-se que, de maneira geral, a mais frustrada expectativa foi daqueles usuários que desejavam agilizar seus movimentos, dos quais 83\% não obtêm seus intentos.

Analisando ainda as expectativas frustradas em relação ao total geral das questões, verifica-se que o segundo lugar fica para os informantes que esperam obter subsídios para o planejamento e tomada de decisões, com 50\% de insucesso. Dos que pretendem desenvolver suas habilidades, 40\% não conseguem. As expectativas "acalmar-se / relaxarse", "continuar desempenho" e "atingir objetivos" não são atingidas cada qual por 33\% dos informantes.

No cômputo geral, a expectativa de maior freqüência entre os informantes é "atingir objetivos, resolver o problema". E esta é uma das categorias na qual os informantes são bem sucedidos. 
TABELA 5.3.4.1

\section{EXPECTATIVA DE USO DA INFORMACุĀO \\ $X$ CLASSES DE USUÁRIOS DA REDE IFUSP \\ (necessidades de informaçâo năo solucionadas)}

\begin{tabular}{|c|c|c|c|c|c|c|c|c|c|c|c|}
\hline \multirow{2}{*}{ CATEGORIAS USUÁRIOS } & \multicolumn{4}{|c|}{ ALUNO } & \multicolumn{4}{|c|}{ DOCENTE } & \multirow{2}{*}{\begin{tabular}{|c|} 
PESQ \\
PD \\
\end{tabular}} & \multirow{2}{*}{\begin{tabular}{|c|} 
FUNC. \\
GR \\
\end{tabular}} & \multirow[t]{2}{*}{ TOTAL } \\
\hline & GR & ME & $\mathrm{DR}$ & ST & DR & PD & LD & ST & & & \\
\hline Continuar desempenho & - & 2 & - & 2 & - & - & - & - & - & - & 2 \\
\hline Contatar pessoas & - & - & - & - & - & - & - & - & - & - & - \\
\hline Desenvolver habilidade & - & - & 1 & 1 & 1 & - & - & 1 & - & - & 2 \\
\hline Compreender situaçẫo & - & - & - & - & 1 & - & - & 1 & 1 & - & 2 \\
\hline Alcançar objetivos & - & 1 & - & 1 & 2 & - & - & 2 & 1 & 1 & 5 \\
\hline Planejar, decidir & - & 1 & - & 1 & 1 & - & - & 1 & 1 & - & 3 \\
\hline Agilizar o movimento & - & 1 & 3 & 4 & 1 & - & - & 1 & - & - & 5 \\
\hline Acalmar-se, relaxar & - & - & 1 & 1 & - & - & - & - & - & - & 1 \\
\hline Outros & - & 1 & 1 & 2 & $\cdot$ & - & - & - & - & - & 2 \\
\hline Sub-total & - & 6 & 6 & 12 & 6 & - & - & 6 & 3 & 1 & 22 \\
\hline Necessidades solucionadas & 3 & 4 & 11 & 18 & 4 & 1 & - & 5 & 1 & 6 & 30 \\
\hline Incompletos/Anulados & 2 & 2 & 7 & 11 & 8 & 1 & 3 & 12 & 2 & 1 & 26 \\
\hline$S / R$ & - & 1 & 1 & 2 & 4 & - & - & 4 & 3 & $\cdot$ & 9 \\
\hline TOTAL & 5 & 13 & 25 & 43 & 22 & 2 & 3 & 27 & 9 & 8 & 87 \\
\hline
\end{tabular}

5.3.5 Estratégias Empreendidas - necessidades de informação não solucionadas (cf. Tabela 5.3.5.1, AC \#07 - Apêndice B)

A estratégia "consultar colegas pessoalmente" (face-a-face) e a de menor sucesso, correspondendo a $21 \%$ do total. A "consulta a pares" (via email, face-a-face ou em grupos de discussões eletrônicas) vem a seguir, na escala das estratégias mal sucedidas, com 18\%. O "desenvolvimento por si próprio" de procedimentos e experimentos atinge 15\% e a "consulta aos recursos da rede", 12\%. "Consultar a si próprio" não soluciona $6 \%$ dos cases.

Comparando esses resultados com o total de estratégias empreendidas (cf. Tabela 5.2.5.1), conclui-se: $100 \%$ dos informantes que utilizam a estratégia "consultar a si próprio", $50 \%$ dos informantes que consultam colegas pessoalmente, $28 \%$ dos que pedem auxílio aos pares e $28,5 \%$ dos que utilizam recursos via rede, não obtém sucesso. 
TABELA 5.3.5.1

\section{ESTRATÉGIAS EMPREENDIDAS \\ $X$ CLASSES DE USUÁRIOS DA REDE IFUSP \\ (necessidades de informação não solucionadas)}

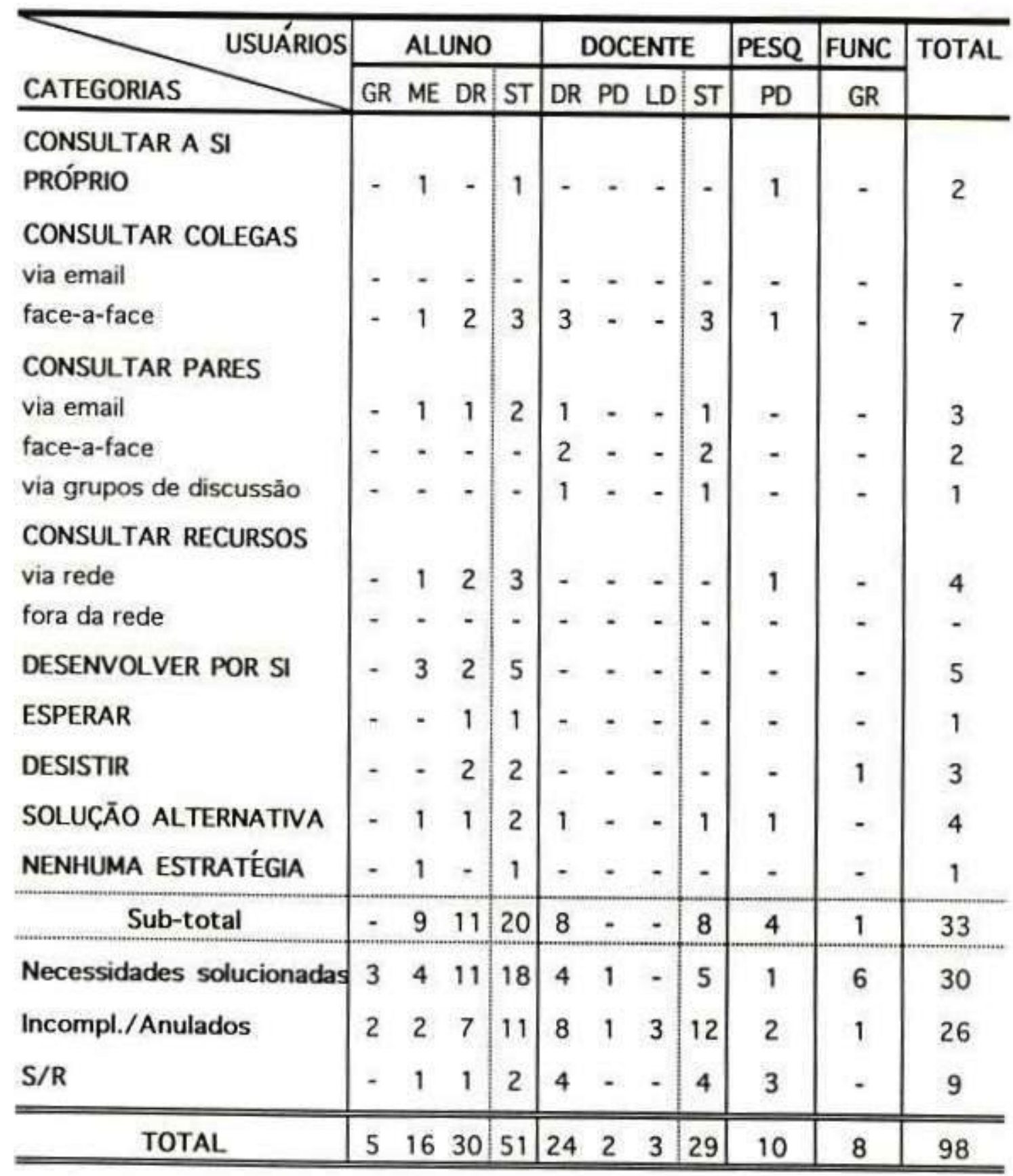

Obs.: Questão múltipla 


\section{Capítulo 6}

CONSIDERAÇÕES FINAIS 


\section{CONSIDERAÇÕES FINAIS}

Das contribuições dos estudos realizados e discussões feitas à volta de dois temas emergentes "Redes Eletrônicas" e "Necessidades de informação Centrada no Usuário", aliados a recomendações finais, de modo especifico e geral, são agora agrupados os resultados mais significativos, a saber:

\section{DE MODO ESPECIFICO}

\subsection{FUNDAMENTOS DOS ESTUDOS E PESQUISA}

\subsubsection{Desenvolvimento das Redes Eletrônicas}

* A Internet, rede das redes, e um dos destaques deste século no que diz respeito à facilidade, agilidade, interatividade e eficiência do acesso a quantidades imensuráveis de informação em nível mundial. Novas redes têm surgido em quantidade exponencial em ambientes militares, acadêmicos, educacionais, governamentais e, mais recentemente, comerciais.

* No Brasil, a partir de 1989 a Rede Nacional de Pesquisa (RNP) iniciou a implementação da espinha dorsal, o backbone da Internet brasileira. De forma lenta, mas já com grandes alcances, tem sido desenvolvido um trabalho de conscientização da comunidade científica em âmbito nacional. Por outro lado, inúmeros serviços e produtos nacionais estão disponíveis à comunidade internacional, através da Internet, particularmente nas instituições alocadas no Sudeste do país.

* Atualmente, em termos metafóricos, a Internet pode ser comparada a uma grande árvore. Os equipamentos de hardware e software são a sustentação, a raiz. Os recursos e aplicativos tecnológicos que diariamente estão surgindo no mercado representam o tronco. Acima de tudo, encontra-se a informação reunida visando facilitar geração, acesso e uso pela comunidade. Somente o conhecimento e entendimento dessa estrutura como um todo, bem como o discernimento da capacidade das RE e a exploração das suas reais possibilidades permitirão o uso das redes eletrônicas em toda a sua potencialidade para o máximo usufruto. Tais atributos não têm sido observados de modo integral entre vários indivíduos da comunidade acadêmica. 
* A literatura nacional, ainda escassa, exige que sejam produzidos sistematizações, estudos de revisão ou estado da arte e memória científica.

\subsubsection{Ambiência universitária que utiliza as RE}

* No Instituto de Física da USP - universo selecionado para realização desta pesquisa

- constata-se a existência de condições propícias para uso efetivo da comunicação eletrônica. As instalações físicas e estruturais de sua rede local, as facilidades de acesso a terminais instalados em vários pontos de todos os prédios do Instituto, o acompanhamento e assistência técnica disponível, e os diversos serviços e produtos desenvolvidos pelo Centro de Computação e também pela Biblioteca revelam a filosofia valorização das RE como instrumento de comunicação (em parte para informação) e complemento imprescindível as atividades de ensino, pesquisa e extensão.

* A comunidade usuária da rede eletrônica local - constituída por docentes, alunos, pesquisadores e funcionários em geral - pode ser categorizada em etapas de desempenho quando da busca e uso da informação.

\subsection{ABORDAGEM DO SENSE-MAKING}

* Baseada nos pressupostos da subjetividade da informação, da descontinuidade da realidade e das modificações a que os indivíduos estão sujeitos conforme suas localizações temporais e espaciais, esta abordagem prescreve uma série de procedimentos e técnicas para se mapear como esses indivíduos percebem seus movimentos em busca de informação. Tais métodos e técnicas têm comprovado sua eficiência em vários contextos da Ciência da informação.

* A adaptação de tal abordagem para estudos de necessidades de informação de usuanos de redes eletrônicas em ambiente universitário foi considerada adequada face dos resultados obtidos. Pode-se afirmar que a serie de procedimentos metodológicos desenvolvidos no contexto de outras culturas diferenciadas de países do $1^{\circ}$ mundo e passível também de ser utilizada em ambiente brasileiro.

* Como abordagem centrada no usuário, o Sense-Making procura evidenciar particularidades de indivíduos para determinar incidências da população em estudo. 
* As técnicas empregadas para mapear, codificar e rotular procedimentos cotidianos são consideradas adequadas a este estudo, tendo em vista que os informantes puderam recapitular situações e transcrevê-las nos detalhes solicitados. Vale lembrar que foi simplificado o emprego da técnica de coleta de dados, limitando-se a manipulação de apenas uma necessidade de informação por usuário. Novos estudos devem ser repetidos com adequações as várias áreas de conhecimento.

* O Instrumento de pesquisa, com 25 questões abertas e uma única fechada, transmitido digitalmente via correio eletrônico, propicia condições favoráveis de diálogo e intercâmbio, com certas vantagens sobre as tradicionais entrevistas face-a-face e/ou questionários via correio postal. Dos inúmeros benefícios, identificados quando da seleção deste recurso, comprovaram-se: acesso fácil; informalidade criando elo amigável entre pesquisador e informantes; rapidez e/ou agilidade na troca de correspondência (circularam um total aproximado de 300 mensagens entre os 87 informantes e a pesquisadora) e maleabilidade de comunicação a qualquer hora e lugar, conforme conveniência das pessoas. Dessa forma, pode-se constatar um comportamento ágil dos informantes no manuseio do correio eletrônico.

* A análise de conteúdo, parte fundamental da pesquisa, permitiu evidenciar importantes variáveis e categorizações específicas para estudos como o realizado. Considera-se, pois que os esquemas elaborados para essas análises (inseridos no Apêndice B e analisados no Cap. 5), por si só, são representativos dos indicadores das necessidades de informação de comunidade acadêmica quando da busca e uso da informação através das redes eletrônicas.

* De maneira sintética, tais indicadores submergiram das análises efetuadas, em função de 10 variáveis da pesquisa:

- contexto de utilização das redes eletrônicas;

- natureza das necessidades de informação:

"quem", "o que", "onde", "quando", "como" e "por que";

- foco das necessidades: "própria pessoa", "outra pessoa", "situação", "objeto";

- estratégias empreendidas para solucioná-las;

- expectativa dos usuários;

- esforço dispendido para localizar respostas;

- recursos informacionais utilizados;

- completeza das respostas obtidas;

- satisfação com as respostas obtidas;

- fonte efetiva de auxílio. 
* Essas necessidades, detectadas sob a ótica dos usuários, e contrapostas às características peculiares quanto ao conhecimento, freqüência e problemas deflagrados no uso das redes eletrônicas, resultaram na determinação de importantes padrões de comportamento da comunidade estudada, os quais a seguir são discriminados:

\subsection{NECESSIDADES DOS USUÁRIOS DO IFUSP}

* Estudo realizado no fim do 20. semestre de 1994, no IFUSP, revela similaridades e diferenças cntre o comportamento das várias classes de usuários que utilizam a rede IFUSP (cf. Cap. 5). Optou-se por levantar as informações relevantes desta comunidade, de um modo generalizado e não específico a cada classe (estudantes, docentes, pesquisadores, funcionários) em virtude de não haver diferenças significativas entre os mesmos. atentandose, na verdade, para os objetivos propostos neste trabalho, cujo interesse e chegar a um perfil preliminar de necessidades de informação. O importante foi apontar um status quo dessa realidade institucional, no momento.

* O instrumento de pesquisa, compreende formalmente três partes: identificação dos usuários; conhecimento e uso dos recursos e serviços das RE; situação de uso recente das mesmas.

Dos resultados de três análises, sintetiza-se o que segue:

\subsubsection{Identificação dos Usuários}

* Os usuários da rede, em sua maioria, são do sexo masculino e essa realidade se espalha na população estudada. Em termos percentuais, porém comparando o número de informantes com o total de usuários de cada sexo, chega-se a uma representatividade equitativa. Entre as idades de 20 a 62 anos, se configura 5 alunos de graduação, 13 de mestrado e 25 de doutorado; 22 professores doutores, 2 pós-doutores e 3 livre-docentes; 9 pesquisadores em regime de pós-doutoramento e 8 funcionários na categoria de pessoal de apoio ao ensino e pesquisa.

* Do universo de 536 usuários, 87 voluntários constituíram a população de estudo. São elementos do quadro de ensino e pesquisa do Instituto de Física, porém, grande parte exerce atividades de pesquisa. A receptividade e interesse desses voluntários contribuiu para 0 sucesso da coleta de dados. 
* Falhas de registros universitários - impossibilitando a definição exata de usuários, quer reais e potenciais como ativos e inativos - impingiram certas limitações ao controle mais efetivo da amostragem desta pesquisa.

\subsubsection{Conhecimento e Uso dos Recursos das Redes Eletrônicas}

* De maneira geral, excluindo as três funções básicas das RE (correio eletrônico, FTP e telnet), pode-se detectar que os demais recursos e serviços disponíveis são, de alguma forma, desconhecidos e/ou nunca utilizados pela grande maioria dos informantes. Estão incluídos aqui os serviços e produtos mantidos pelo CCIFUSP, concluindo-se, portanto, que a oferta de recursos e serviços tem sido muito maior do que a demanda.

* O principal motivo da utilização das redes e a comunicação interpessoal e/ou entre máquinas, seguido pela busca de soluções para questões técnicas, administrativas e/ou pessoais. A busca e recuperação de informação diversificada e o uso das redes para adquirir domínio sobre a mesma são as ra/ocs menos indicadas.

* com referência à existência de barreiras e dificuldades no uso das RE, segundo suas próprias perspectivas, depara-se com uns grupos privilegiados cujos maiores problemas são aqueles comuns a todos, e encontrados em qualquer ambiente de rede, mesmo em nível internacional, ou seja, questões relativas à conexão, tráfico intenso e outros. São apontadas poucas dificuldades de ordem pessoal, lingüística c/ou tecnológica.

\subsubsection{Situação de Uso Recente das Redes Eletrônicas}

* Os usuários, de maneira geral, preocupam-se com aquisição de hábitos, procedimentos, habilidades necessárias a solução de diversas situações defrontadas ao utilizar as redes. Em seguida, demonstram interesse natural pelas informações inerentes as redes.

* A obtenção de informação por meio eletrônico, em primeiro lugar, está relacionada ao alcance imediato da solução de problemas; em seguida, para apoderar-se do controle dos mesmos.

* Sobre as estratégias de busca, os primeiros questionamentos acontecem junto aos pares, na maioria das vezes via correio eletrônico; como segunda alternativa buscam apoio junto 
as colegas e pessoas próximas, que, por sua vez, são também valiosas fontes de informação.

* Metade dos informantes consegue solucionar suas necessidades de informação no uso das RE e se mostra satisfeita, em virtude de ter, realmente, resolvido o problema.

* De maneira geral, os usuários dispendem poucos esforços para localizar respostas, consultando recursos mais próximos e fáceis+

* Implicitamente, os resultados da análise das necessidades de informação não solucionadas demonstra as condições de dificuldades enfrentadas pelos usuários quando da utilização das redes eletrônicas. Estes resultados, para devida Ciência de administradores, educadores, cientistas da informação e projetistas de sistemas podem ser úteis para programações de suas áreas, implementações, revisões, modificações e melhoramento de serviços oferecidos.

* No cômputo geral, constatam-se quatro categorias de usuários das redes eletrônicas, em níveis diferenciados, conforme experiência de uso, a saber:

- FASE 1: usuários descobrindo a existência das RE, indagando por suas vantagens, benefícios e tipos de aplicações nas diferentes atividades profissionais. correspondem a $6 \%$ dos informantes.

- FASE 2: usuários que já incorporam em suas atividades didrias o uso específico das três funções básicas das RE, quais sejam: o correio eletrônico, o protocolo de transferência de arquivos e a conexão remota. As duas últimas atividades, no entanto, estão restritas ao uso da rede como extensão do microcomputador, isto é, utilizam-nas apenas para transferir localmente dados do micro particular para o VAX, rodar programas em computadores de grande porte do próprio Instituto, e recuperar os resultados. Correspondem a $32 \%$ dos informantes.

- FASE 3: usuários que utilizam as redes para solução de questões imediatas, pontuais e de caráter variado. Correspondem a $26 \%$ dos informantes.

- FASE 4: usuários já experimentados, seguros das várias funções e serviços das RE, com pleno domínio de suas potencialidades. Demonstram a pratica de uso da rede, não só como mero equipamento tecnológico de comunicação para compartilhar recursos computacionais, mas como uma real fonte de informação. Correspondem a $25 \%$ dos informantes. 
* A situação deflagrada e natural, pois todas as inovações passam pelos estágios de compreensão, inclusão, adoção e transformação. Em se tratando, porém, de uma comunidade de área tecnológica - em que grande maiona e constituída de elementos que utilizam as RE ha muitos anos e estão conectados a uma rede com infra-estrutura física, admmistrativa e operacional bem sedimentada, com muitas facilidades de acesso - contava-se com uma performance mais acentuada.

* Este contexto, somado aos resultados apontados anteriormente, leva-nos a inferir que as redes eletrônicas e a própria rede local do IFUSP vem sendo subutilizadas, dado o grande desconhecimento dos usuanos quanto às potencialidades das mesmas.

\section{DE MODO GERAL}

* Redes eletrônicas implantadas em ambiente universitário são indícios de que atividades de ensino, pesquisa e extensão estão sendo desempenhadas em linha de modernização e transformação.

* A Universidade de São Paulo, já sensibilizada quanto ao potencial desses novos recursos tecnológicos, tem envidado esforços para implantar infra-estrutura básica, principais funções, recursos e serviços de RE. Em virtude da descentralização administrativa e acadêmica havida nos últimos tempos na USP, cabe as diversas unidades e institutos a iniciativa própria de implantar e divulgar seus projetos e realizações acadêmicas, bem como conscientizar sua comunidade a respeito do uso de novas tecnologias.

* A presente pesquisa evidência o status de um Instituto da USP, em franca evolução de redes eletrônicas, quanto \& infra-estrutura e desenvolvimento de serviços e produtos, não obstante ter-se percebido que parte considerável dos membros da comunidade não está plenamente conscientizada da potencialidade das redes em geral e particularmente da rede local.

* Um dos ponto mais importante desta pesquisa recai na evidência de que grande parte dos informantes não tem consciência de ser a rede eletrônica atualmente uma fonte de informação em potencial. Em vista disto, fica evidente que, no ambiente universitário 
brasileiro estudado, as redes eletrônicas estão sendo reconhecidas quase que exclusivamente como recurso de comunicação.

Algumas recomendações ou sugestões, podem ser delineadas:

* Programas de divulgação e promete dos diversos recursos e serviços das RE atuais devem ser implementados, para que sejam otimizados o uso e a exploração das RE.

* Elaboração de manuais sobre usos específicos dos variados recursos e disponíveis; distribuição de guias e roteiros detalhando habilidades necessárias em diferentes situações de uso das redes; cadastros sobre o que esta disponível nas várias áreas de atuação do Instituto são algumas das medidas que podem provocar a busca de mais apoio junto às redes, pelos usuários

* O avanço tecnológico das redes têm sido tal que acompanhar sua evolução tem constituído larefa difícil para os usuários. A falta de tempo, de paciência e muitas vezes de habilidade para navegar em busca de informação nas redes, tem impedido sua utilização eficiente. Novos e melhores produtos e serviços de informação estão sempre surgindo. A disponibilidade de informação nas redes é grande, mas falta organização, disciplinamento, estruturação de valores, avaliações de fidedignidade das mesmas, critérios de seleção e normalização bibliográfica. A necessidade de um intermediador para apoiar os usuários se mostra fundamental.

* Cube ao profissional da informação documentária ser um desses mediadores. Num trabalho integrado com analistas e projetistas de sistemas, é vital que sejam desenvolvidos:

(a) estudos específicos condizentes com as necessidades dos usuários;

(b) serviços pertinentes a essas necessidades e,

(c) programas de capacitação de intermediários entre esses serviços e usuários finais, de modo a facilitar o uso e a recuperação da informação de modo eficiente;

(d) programas de formação em serviços, treinamentos e cursos de reciclagem aos usuários.

* Finalmente, recomenda-se que sejam efetuadas avaliações e revisões periódicas dos produtos e serviços oferecidos eletronicamente, tendo em vista que necessidades informacionais dos usuários tendem a se modificar continuamente. Por outro lado, programações permanentes de atualização devem ser previstas, tendo em conta o acompanhamento do acelerado desenvolvimento tecnológico dos recursos das redes. 
* Crê-se que a importância deste estudo reside não somente na evidência do fenômeno que esta sendo investigado (o qual pode ser útil a projetistas, administradores de sistemas e cientistas da informação na implementação de redes e serviços eletrônicos adequados aos usuários), mas também por ser uma experimentação considerada positiva sobre a utilidade e potencialidade da abordagem centrada no usuário, o Sense-Making. Os resultados obtidos possibilitam melhor compreensão sobre como usuários da rede acadêmica buscam e usam a informação eletrônica em suas atividades profissionais. Enfim, as sugestões deste estudo podem ser validas as causas da comunicação eletrônica e da informação científica nos vários contextos institucionais de universidades brasileiras que procurem compreensão e avanço dessas áreas. 


\section{Capítulo 7}

REFERÊNCIAS BIBLIOGRÁFICAS 


\section{REFERÊNCIAS BIBLIOGRÁFICAS}

AGARWAL, R. (1988). Knowledge acquisition or business expert systems: a decision-centric model and its empirical validation. Syracuse, Dissertation (Ph.D. Degree) Syracuse University, School of Management.

AIMS, A. Survey of information needs of physicists and chemists. Journal of Documentation, v.21, n.2, p.83-121, June.

ALLEN, T.J. (1969) Information needs and uses. Annual Review of Information Science and Technology, v.4, p.3-29.

ALRECK, P.L.; SETTLE, R.B. (1985). The survey research handbook. Homevvood, IL.: Richard D. Irwin

ATWOOD, R.; DERVIN, B. (1981) Challenges to sociocultural predictors of information seeking: a test of race vs. situation movement state. In: M. Burgeon, ed. Communication Yearbook. New Brunswick: Transaction Books, v. 5, p. 549-69.

BASSALO, J.M. (1990). As raízes da física brasileira. Rio de Janeiro: CBP. (CBP-CS006/90).

BELKIN, N.J. (1984) Cognitive models and information transfer. Social Science Information Studies, v.4, n.2/3, p. 111-130, jul.

BELKIN, N.J. ; ODDY, R.N. (1978). Document retrieval based on the automatic determination of the user's information needs. Journal of Informatics, v2, n. 1, p.8-11.

BELKIN, N.J.; ODDY, R.N. ; BROOKS, H.M. (1982) ASK for Information Retrieval: Part I Background and theory. Journal of Documentation, v.38, n.2, p.61-71, Jun. 1982.

BELKIN, N.J. ; ODDY, R.N. ; BROOKS, H.M. (1982) ASK for Information Retrieval: Part II Results of a design study. Journal of Documentation, v.38, n.3, p. 145-164, set.

BRASIL. Ministério da Ciência e Tecnologia. Rede Nacional de Pesquisa. (1994) RNP' 94: planejamento geral. s.I.p.: RNP. (Doc. No. RNP/ORG/0035A).

BROPHY, P. (1993). Networking in British academic libraries. British Journal of Academic Librarianship, v.8, n.I, p.49-60.

BROWN, M.E. (1991). A general model of information-seeking behavior. In: Proceedings of the American Society for Information Science, p. 9-14.

CARTER, R. (1989). What does a gap imply?. Paper prepared for panel, "Finding a more powerful analytic for comparative research: using the gap idea in crosscultural research". Inter cultural and Development Communication Division, International Communication Association Meeting, San Francisco, CA. 
CARTER, R. (1980). Discontinuity and communication. Paper written for the seminar on communication from Eastern and Westerns sponsored by the EastWest Communication Institute, East-West Center, Honolulu, HI.

CHEN, Ching-chih; HERNON, M.P. (1982). Information seeking: assessing and' anticipating user needs. New York: Neal-Schuman.

CHILDERS, T. (1982). Personal Maintenance and Personal Growth. In.: SWENEY, G.P., ed. Information and the Transformation of Society. Amsterdam: North-Holland.

CLAUSEN, H. (1992) Electronic mail and the information professional. Denmark, Dissertation (Ph.D. degree) - The Aarhus School of Business Administration, Economics and Modern Languages.

COELHO NETTO, J.T. (1978). A biblioteca como modelo de sistema de comunicação. Revista Brasileira de Biblioteconomia e Documentação, v. 11, n.l/3, p.29-32.

COHEN, J.A. (1993). The electronic library in higher education: an overview and status report. IPCT: Interpersonal Computing and Technology, an electronic journal for the 21 st century . v. 1, n. 1, Jan.

COLE, C. (1994). Operationalizing the notion of information as a subjective construct. Journal of the American Society for Information Science, v.45, n.7, p.465-76.

COONEY,S.; ALLEN, T.J. (1974) The technological gatekeeper and policies for national and international transfer of information. R\&D Management, v.5, n. 1, p.29-33.

CRAWFORD, S. (1978). Information needs and uses. Annual Review of Information Science and Technology, 13, p.61-81.

CUNHA, M. Metodologias para estudo dos usuários de informação científica e tecnológica. Rev. Bibliotecon. Brasilia, v. 10, n.2, p.5-19, jul./dez.

DERVIN, B. (1976) Strategies for dealing with human information needs: information or communication? Journal of Broadeasting, v.20, p.324-333.

DERVIN, B. (1977) Useful theory for librarianship: communication, not information. Drexel Library Quarterly, v. 13, n.3, p. 16-32.

DERVIN, B. (1979) Meeting individual informing needs in the midst of the information explosion of the 1980's. Colloquium - Visiting Lecture Series of the All University Gerontology Program. Syracuse, NY: Syracuse University.

DERVIN, B. (1980). Communication gaps and inequities: moving toward a reconceptualization. In: DERVIN, B. ; VOIGHT, M.J., ed. Progress in Communication Sciences. Norwood, NJ: Ablex. v. 2, p. 73-112.

DERVIN, B. (1983a) An overview of Sense-Making research: concepts, methods and results to date. In: International Communications Association Annual Meeting. Dallas, May.

DERVIN, B. (1983b). Information as a user construct: the relevance of perceived information needs to synthesis and interpretation. In: WARD, S.A.; RED, L.J., ed. Knowledge Structure and Use: implication for synthesis and interpretation. Philadelphia: Temple University, Press, p. 153-83. 
DERVIN, B. (1989). User as research inventions: how research categories perpetuate inequities. Journal of Communication, v.39, n.3, p.216-32.

DERVIN, B. (1992). From the mind's eye of the user: the sense-making qualitativequantitative methodology. In: Jack D. GLAZIER, J.D.; POWELL, R.R. Qualitative Research in Information Management. Englewood, CO: Libraries Unlimited, p.61-84.

DERVIN, B. (1994). Information <-> Democracy : an examination o underlying assumptions. Journal of the American Society for Information Science, v.45, n.6, p. 369-87.

DERVIN, B. (1995). Mensagem pessoal recebida pelo correio eletrônico em 17 de Janeiro.

DERVIN, B.; CLARK, K.D. (1989). Communication as cultural identity: the invention mandate. Media Development, v.36, n.2, p.5-8.

DERVIN, B.; JACOBSON, T.L.; NILAN, M.S. (1982). Measuring aspects of information seeking: a test of quantitative-qualitative methodology. In.: BURGOON, M., ed. Communication Yearbook. Beverly Hills, Ca: Sage. v.6, p.419-44.

DERVIN, B.; NILAN, M.S., JACOBSON, T.L. (1981). Improving predictions of information use: a comparison o predictor types in a health communication setting. In: BURGOON, M. ed. Communication Yearbook. New Brunswick, N.J.: Transaction Books, v.5, p.807-30.

DERVIN, B. ; NILAN, M. (1986) Information needs and uses. Annual Review of Information Science and Technology, v. 21, p. 3-33.

DOTY, P. (1992). Electronic networks and social change in science. In: Proceedings of the Annual Meeting of the American Society of Information Science, 55. Oct. 26-29. p. 18592.

DRABENSTOTT, K.M. (1994). Analytical review of the library of the future. Washington: Council on Library Resources.

ELLIS, D.; COX, D.; HALL, K. (1993). A comparison of the information seeking patterns of researchers in the Physical and Social sciences, Journal of Documentation, v.49, n.4, p. 356-9, Dec.

FAIBISOFF, S.G.; ELY, D.P. (1976). Information and information needs. Information Reports and Bibliographies, v.5, p.2-16.

FERREIRA, A.B.H.(s.d.) Novo dicionário da língua portuguesa. Rio de Janeiro: Nova Fronteira.

FERREIRA, S.M.S.P. (1989) Serviço referencial: conceituação e caracterização. São Paulo, Dissertação (Mestrado) - Escola de Comunicações e Artes, Universidade de São Paulo.

FERREIRA, S.M.S.P. (1994a) Electronic Networking in Brazil. FID News Bulletin, v.44, n. 11, p. 268-72. Nov.

FERREIRA, S.M.S.P. (1994b). Visão introdutória das redes eletrônicas de comunicação. Ciência da Informação, (no prelo). 
FERRI, M.G.; MOTOYAMA, S.; coord. (1979). História das Ciências no Brasil. São Paulo: EPU/EDUSP.

FIGUEIREDO, N.M. (1979). Avaliação de coleções e estudo de usuários. Brasília: ABDF.

FIGUEIREDO, N.M. (1983). Aspectos especiais de estudos de usuários. Ciência da Informação, v.12, n.2, p.43-57, jul./dez.

FIGUEIREDO, N.M.(1994). Estudos de uso e usuários da informação. Brasilia: CNPq/BB.

FISHER, R. (1982) Common problems in library resources for off-campus students. In: CROCKER, C., ed. Library services in distance education. Brisbane: Library Association of Australia.

FLETCHER, P. (1991). An examination of situational dimension in the information behaviors of general managers. Syracuse, Dissertation (Ph.D. Degree) - Syracuse University, School of Information Studies.

FORD, G. (1973). Progress in documentation: research on user behavior in universities libraries. Journal of Documentation, v.29, n.l, p.85-106.

FORD, N. (1980). Relating "Information Needs" to learner characteristics in higher education. Journal of Documentation, v.36, n.2, p.99-114.

FORD, N. (1983) Knowledge structures in human and machine - their representation and interaction. Social Science Information Studies, v.3, p.209-22.

FREEMAN, C.L.; ALLON, E. (1986) Communication: pure and simple, s.l: Burroughs Corporation/Corporate Program Management Detroit.

GAINS, D. (1978) Libraries and other information sources for Open University students on higher level courses in 1976. Teaching at a Distance, v. 11, p.65-69.

CARTON, L.; WILLMAN, B. (1995). Social impacts of electronic mail in organizations: a review of the research literature. In: BURLESON, B. R. ed. Communication Yearbook. Thousand Oaks: Sage, v.18, p.434-53.

GETSCHKO, D. ; STANTON, M.A. (1992). A evolu9ão de redes acadêmicas no país. In: 10. Congresso Anual da Sociedade Brasileira para o Progresso da Ciência, Recife, abril 1992.

GARVEY, W.D. (1979) Communication: the essence of science - facilitating information exchange among librarians, scientists, engineers and students. Elmsford/NY: Pergamon Press.

GARVEY, W.D. et alii. (1979) The dynamic scientific-information user. In: GARVEY, W.D. Communication: the essence of science. Elmsford/NY: Pergamon Press, p.256-279.

GLUCK, M.H. (1992) Understanding performance in information systems: an investigation of system and user views of geographic information. Syracuse, Dissertation (Ph.D. degree) - School of Information Studies, Syracuse University.

HARDY, H.E. (1993) The History of the net. Allendale, Thesis (Master degree) School of Communications/Grand Valley State University. 
HENNING, P.C. (1993) Internet@RNP.BR: um novo recurso de acesso á informação. Ciência da Informação, Brasília, v.22, n.l, p.61-4, jan./abr. 1993.

HENNING, P.C. (1994) INTERNET@rnp.br: um novo recurso de acesso á informação. Rio de Janeiro, Dissertação (Mestrado) - Universidade Federal do Rio de Janeiro.

HERNER, S.; HERNER, M. (1967). Information needs and uses in science and technology. Annual Review of Information Science and Technology, v.2, p. 1-34.

HEWINS, E.T. (1990). Information need and use studies. Annual Review of Information Science and Technology, v.25, p. 145-72.

JAMES, R. (1983) Libraries in the mind: how can we see users perceptions of libraries? Journal of Librarianship, v.15, n.I, p. 19-28.

KEHOE, B.P. (1992) Zen \& the art of Internet: a beginner's guide to the Internet. S.l.: Widener University Computer Services. (disponível por ftp: FTP.cs.widner.edu/pub/zen/znI.0ps).

KERLINGER, F.N. (1986). Foundations of behavioral research. 3.cd. Chicago, IL: Holt, Rinehart and Winston, Inc.

KENNEY, L. (1966). The implications of the needs of users for the design of a catalogue: a survey at the International Labor Office. Journal of Documentation, v.22, n.3, p. 195-202.

KRIKELAS, J. (1983) Information-seeking behavior: patterns and concepts. Drexel Library Quarterly, v.19, n.2, p.5-20.

KROL, E. (1992) The whole Internet user's guide; catalog. Sebastopol/CA: O'Reilly ; Associates.

KURAMOTO, H. (1994). Rede Antares: uma nova perspectiva. In: Anais. Seminário de Automação de Bibliotecas, 5., São Jose dos Campos, INPE/UNIVAP, 19 a 22 de julho de 1994. p. 004..

LANCASTER, F.W. (1978). Toward paperless information systems. New York: Academic Press.

LIN, N. ; GARVEY, W.D. (1972). Information needs and uses. Annual Review of Information Science and Technology, v.7, p.5-37.

LINE, M.B. (1971) The information uses and needs of social scientists: an overview of INFROSS. Aslib Proceedings, v.23, p.412-434.

LOPES, M.I.V. (1993). Estratégias metodológicas da pesquisa de recepção. INTERCOM: Revista Brasileira de Comunicação, v.16, n.2, p.78-86, jul./dez.

LYNCH, C.A. (1992) Foreword. In: TENNANT, R.; OBER, J.; LIPOW, A.G. Crossing the Internet threshold: an instructional handbook. Berkeley: Library Solutions Press, 1992. p.viiviii.

LYNCH, C.A. (1993). The transformation of scholarly communication and the role of the library in the age of networked information. The Serials Librarian, v.23, n.3/4, p.5-20. 
LYNCH, C.A. (1994). The integrity of digital information: mechanics and definitional issues. Journal of the American Society for Information Science, v.45, n. 10, p.737-44, Dec.

LYNCH, C.A. ; PRESTON, C.M. (1990). Internet access to information resources/ Annual Review of Information Science and Technology, v.25, p.263-312.

MAEMULLIN, S.E ; TAYLOR, R.S. (1984) Problem dimensions and information traits. The Information Society, v.3, n.I, p.91-111.

MARCHIONINI, G. (1992). Interfaces for end-user information seeking. Journal of the American Society for Information Science, v.43, n.2, p. 156-63, March.

MENZEL, H. (1966) Information needs and uses in science and technology. Annual Review of Information Science and Technology, v.l, p.41-69.

MICK, C.K.; LINDSEY, G.N.; CALLAHAN, D. (1980). Toward usable user studies. Journal of the ASIS, v.31, n.5, p.347-56.

MORAN, J.M. (1994) Interferências dos meios de comunicação no nosso conhecimento. Ciência da Informação, (no prelo).

MORGADO, E. (1991) Avaliação da implantação da rede BITNET nas universidades estaduais paulistas. São Paulo, Dissertação (Mestrado) Faculdade de Economia e Administração/Universidade de São Paulo.

MORRIS, R.C.T. (1994). Toward a user-centered information science. Journal of the American Society for Information Science, v. 45, n.I, Jan.

NEIL, S.D. (1987) The dilemma of the subjective in information organization and retrieval. Journal of Documentation, v.43, p. 193-211.

NILAN, M.S. (1992) User-based information/communication systems: using sense-making to create a user model for a desktop publishing help and training system, [s.n.t.] [Draft].

NILAN, M.S. et all (1989). User-oriented interfaces for computer systems: a user defined online help system for desktop publishing. In: Proceedings of the 52nd Annual Meeting of the American Society for Information Science, v.26, p. 166-

171.

NILAN, M.S.; FLETCHER, P.T. (1987) Information behaviors in the preparation of research proposals: a user study. In: Proceedings of the American Society for Information Science. Medford/NJ, Learned Information, 1987. v.24, p. 186-192.

NILAN, M.S.; PANNEN, P. (1989) User defined information system design specification for specific sub-groups: an example with resident and non-resident university students. In: Proceedings of the 52nd Annual Meeting of the American Society of Information Science, v.26, p. 166-71.

OROZCO, G. (1991). Recepcion televisiva: tres aproximaciones y una razon para un estudio. México: Universidade Ibero Americana. (Cuadernos de Comunicación y Practicas Seriales, n.z)

ORTON, L.; WISEMAN, J. (1977) Library services to part-time students. Canadian Library Journal, v.34, n. 1, p.23-27.

PAÍSLEY, W.J. (1968). Information needs and uses. Annual Review of Information Science and Technology, v.3, p. 1-30. 
PAÍSLEY, W. (1980) Information and work. In: Dervin, Brenda ; Voigt, Melvm, ed. Progress in Communication Sciences. Norwood/NJ: Ablex Publishing. v.2.

PAÍSLEY, W.J. : PARKER, E.B. (1967) Scientific information exchange scientific at an interdisciplinary behavioral science convention. Stanford, CA: Stanford University, Institute for Communication Research.

PANNEN, P. (1990) A study in information seeking and use behaviors of resident students and non-resident students in Indonesian Tertiary Education. Syracuse, Dissertation (Ph.D. degree) - School of Education, Syracuse University.

PIOVESAN, A. (1977). Glossário para o curso de Metodologia de Pesquisa Científica São Paulo: USP/Faculdade de Saúde Pública.

PENLAND, P.R. (1976). Learning pattern of librarian clients. Pittsburg, PA: Pittsburgh University.

POBLACiON, D.A. (1992) Literatura cinzenta ou não convencional: um desafio a ser enfrentado. Ciência da Informação, v.21, n.3, p.243-246, set./dez.

POPPER, K. (1972). Objective knowledge: an evolutionary approach. London: Oxford.

PRICE, D.J.S. (1976) O desenvolvimento da Ciência. Trad. Simco Mathias. Rio de Janeiro: Livros Tdenicos.

PRINGGOADISURYO, L. (1984) Stimulating the use of information in a developing country. In: A Van der Lann ; A.A. Winters, eds. The use of information in a changing world. Proceedings of the 42nd FID Congress, The Hague, Netherlands.

RAITT, D. The future of libraries in the face of the Internet. The Electronic Library, v.12, n.5, p.275-6, Oct.

RHODE, N.F. (1986) Information needs. In: W. Simonton, ed. Advances in Librarianship, v. 14, p.49-73. New York: Academic Press.

RIEGER, J.H. ; ANDERSON, R.C. (1968). Information service and need hierarchies of an adult population in five Michigan Counties. Adult Education Journal, v. 18, p. 155-75.

ROUSE, W.B.; ROUSE, S.H. (1984). Human information seeking and design of information systems. Information Processing and Management, v.20, n. 1-2, p. 129-38.

SAVOLAINEN, R. (1993). The Sense-Making theory: reviewing the interests of a usercentered approach to information seeking and use. Information Processing \& Management, v.29, n. 1, p. 13-28.

SCHAMBER, L. (1991). User's criteria for evaluation in a multimedia environment. In: Proceedings of the American Society for Information Science, p. 126-132.

SCHAMBER, L. et all. (1990). A re-examination of relevance: toward a dynamic, situational definition. Information Processing; Management, v.26, n.6, p.755-76. 
SCHWARTZMAN, S. (1979). Formação da comunidade científica no Brasil. São Paulo: Ed. Nacional, Rio de Janeiro: INEP, 1979. (Biblioteca Universitária; Série 8: Estudos em Ciência e Tecnologia, v.2).

SHIELDS, P. et alii. (1993). Who needs "post-plus" services?: a comparison o" residential user needs along the rural-urban continuun, Telecommunication Policy, p. 563-87.

SOMMER, R.; SOMMER, B.B. (1986). A practical guide to behavioral research: tools and techniques. 2.d. New York: Oxford University Press.

STANTON, N. (1993) Introdução ás opções de redes, [transparências]. In: Seminário de Informática da ADUSP/UNESP, 2. GuaratinguetaVSP: UNESP/FEG. set. 9-10.

STEMPEL, G. H. (1955) Increasing reliability in content analysis. Journalism Quarterly, v.22, n.4, p.449-455, 1955.

STONE, S. (1982). Humanities scholars: information needs and uses. Journal of Documentation, v.38, n.4, p.292-313.

TAKAHASHI, T. (1993) A Rede Nacional de Pesquisa (RNP): uma visão política. s.l.p., RNP. (Doc. no. RNP/DIV/0001).

TAYLOR, R.S. (1984) Value-add processes in document bases systems: abstracting and indexing services. Information services and uses, v.4, n.3, p. 127-46.

TAYLOR, R.S. (1986) Value-added processes in information system. Norwood, NJ: Ablcx.

TESSIER, J.A. (1981). Toward the understanding of user satisfaction: a multiattribute study of user evaluations of computer-based literature searches in medical libraries. Syracuse, Dissertation (Ph.D. degree) - Syracuse University.

TILKIAN, S. (1994). Guia do Repositório de Ciência e Tecnologia. ed. prel. s.I.: RNP. (Doc. $\mathrm{n}^{\circ} \mathrm{RNP/RF/0041).}$

TUROFF, M.; HILTZ, S.R. (1988). Computer mediated communications and developing countries. Telematics and Informatics, v.5, n.4, p. 357-76.

UNIVERSIDADE DE SÃO PAULO. Centra de Computacão Eletrônica. (1992). PROJETO: Rede USPNet, integração das redes locais. São Paulo: CCE/USP. (Documento restrito)

UNIVERSIDADE DE SÃO PAULO. Comissão Central de Informática. Grupo de Assessoramento Técnico em Informática. (1994). Rede computacional da Universidade de São Paulo/USPNET : projeto de instalação. São Paulo: CCl/GATI. (Documento preliminar e restrito).

UNIVERSIDADE DE SÃO PAULO. Instituto de Física. (1994a). Relatório de Atividades: 1993. São Paulo, IFUSP.

UNIVERSIDADE DE SÃO PAULO. Instituto de Física. (1994b). Visita ao Instituto de Física. São Paulo: IFUSP. (Projeto: Universidade e as Profissões. Pró-Reitoria de Cultura e Extensão Universitária).

VARGAS, I. (1994). A informação e as redes eletrônicas. Ciência da Informação, v.23, n.I, p.7-8, jan./abr. 
VARGAS, I. (1995). A Internet brasileira na encruzilhada. Jornal do Brasil, Mar.06, 1995.

VIEIRA, A.S. (1994). Redes de ICT e a participação brasileira. Brasilia: IBICT/SEBRAE.

WARNER, E.S.; MURRAY, A.D., PALMOUR, V.E. (1973). Information needs of urban residents. Washington, DE: U.S. Department of Health, Education and Welfare.

WEBER, R.P. (1986). Basic Content Analysis. Beverly Hills, CA: Sage Pubs. (Sage University Paper Series on Quantitative Application in the Social Sciences, 07-049).

WILSON, T.D. (1981) On user studies and information needs. Journal of Documentation, v.37, n. 1, p.3-15, Mar.

WILSON, T.D. (1984). The cognitive approach to information seeking behavior and information use. Social Science Information Studies, v.4 p. 197-204.

ZWEIZIG, D. (1979). The information function of adult services in public libraries. RQ.,v.8, p.240-44.

ZWEIZIG, D.; DERVIN, B. (1977) Public library use, users, uses: advances in knowledge of the characteristics and needs of the clientele of American Public Libraries. In: M.J. Voigt; M.H. Karris, eds. Advances in Librarianship. New York: Academic Press, v.7. 
APÊNDICES 


\section{Apêndice A}

INSTRUMENTO DE PESQUISA 


\section{INSTRUMENTO DE PESQUISA}

\section{DADOS DE IDENTIFICAÇÃO}

1.1 Local, no IFUSP, onde desenvolve suas atividades

Departamento:

Grupo de Pesquisa/Laboratório:

Outros:

1.2 Posições que ocupa (docente, aluno, etc.):

1.3 Idade:

1.4 Sexo:

1.5 Formação acadêmica de mais alto nível:

Na área de:

( ) concluído em: Instituição:

( ) em andamento: Instituição:

OBS.: No caso de aluno(a) de graduação indicar o semestre letivo em que esta matriculado(a):

2 CONHECIMENTO / USO DOS RECURSOS DISPONÍVEIS NA RE

2.1 Tempo de experiência no uso de computadores:

2.2 Tempo de experiência no uso das redes:

DECNET:

BITNET:

INTERNET:

2.1 Quais dos serviços elou aplicativos abaixo conhece e utiliza? CODIFICAÇÃO

Correio eletrônico: ( )

Transferência arquivo/FTP: ( )

Conexão remota/Telnet: ( )

Não conheço/Nunca usei (0)

BBS/Bulletin Board System: ( )

Conheço/Nunca usei (1)

News RDR da USENET : ( )

Uso de vez em quando (2)

Archie ()

Uso várias vezes/mês (3)

-Finger ( )

Uso várias vezes/semana (4)

-NetFind ( )

Uso diariamente (5)

-VERONICA ( )

-WAIS ( )

-CWIS ( )

- Gopher ( ) -MOSAIC ( )

- WWW/World Wide Web: ( ) 
- Catálogos de bibliotecas: ( )

- Bases de dados:

- Outros. Especifique-os

2.4 com que propósitos, mais frequentemente, utiliza esses serviços e aplicativos listados acima?

2.5 Participa de Listas de Discussão (ListServ)? Quais?

2.6 Têm encontrado barreiras/dificuldades no USO das redes? Quais?

2.7 Têm encontrado barreiras/dificuldades para ENCONTRAR informação na rede? Quais?

2.8 Teve treinamento formal para aprender a usar a RE? Se sim, onde e quando. Se não,como se iniciou.

\section{SITUAÇÃO RECENTE DE USO DA REDE ELETRÔNICA}

3.1 Tente relembrar às vezes em que utilizou a rede para solucionar algum problema, resolver uma dificuldade ou localizar respostas a perguntas. Descreva aqui, brevemente, o problema chave que desencadeou a situação MAIS RECENTE.

3.2 Descreva, sucintamente, o que aconteceu naquela ocasião, quais atitudes tomou. O que ocorreu primeiro, segundo, terceiro, e assim por diante.

3.3 Pensando em tudo o que aconteceu, descreva, em FORMA DE PERGUNTA, a mais significativa dúvida (receio/anseio/ expectativa) que teve durante o decorrer da situação.

PERGUNTA:

3.4 De que maneira a resposta a sua questão podena, naquela situação, auxiliar na solução de seu problema ou dificuldade?

3.5 Como foi a resposta para sua questão?

Não obteve resposta na ocasião ( ) Passe para o item 3.10 Parcial ( )

Completa ( )

Excessiva ( )

3.6 Qual a razão da resposta ter sido parcial, completa ou excessiva?

3.7 Verbalize, numa sentença objetiva, o conteúdo da resposta obtida. 
3.8 Identifique, por grau de pouco ou mais intensidade, a sua satisfação com a resposta obtida:

Mínima

( )

Regular

Máxima satisfação

3.9 Qual a razão que contribuiu para esse grau de satisfação?

3. 10 Quanto esforço colocou para encontrar a resposta para sua questão? Nenhum ( ) Mínimo ( )

Regular ( )

Máximo esforço ( )

3.11 Tentou obter a resposta de algum outro modo em outra situação? Qual?

3.12 Tente relembrar quais RECURSOS INFORMACIONAIS (contatos pessoais, listas de discussão, Usenet, arquivos FTP, gopher, catálogos de bibliotecas, bibliografias etc...) considerou significativas para buscar resposta a sua questão. Dentre esses, descreva:

a) quais recursos cogitou usar e por que,

b) quais efetivamente utilizou e por que,

c) qual deles realmente forneceu a resposta.

4 Caso queira tecer mais algum comentário a respeito de sua experiência pessoal com as redes, ou mesmo sobre este instrumento de pesquisa, por favor, faça-o aqui.

MUITO OBRIGADA PELA SUA PARTICIPAÇÃO

. POR FAVOR, ENVIE SEU QUESTIONARIO PARA O ENDEREÇO:

SMFERREI@IF.USP.BR 
Apêndice B

\section{ESQUEMA DAS ANÁLISES DE CONTEÚDO}




\section{QUADRO GERAL PARA ANÁLISE DOS DADOS}

Variáveis e formato para processamento dos dados colhidos para o Estudo do Comportamento de Busca e Uso da Informação por usuários da rede eletrônica junto ao Instituto de Física da Universidade de São Paulo.

\begin{tabular}{|c|c|c|c|}
\hline \#ÍTEM & \#COLUNA & $\begin{array}{l}\text { DESCRIÇÃO DA } \\
\text { VARIÁVEL }\end{array}$ & CÓDIGO \\
\hline 001 & A & $\mathrm{N}^{\circ}$ de ordem do informante & $1-87$ \\
\hline - & B-H & DADOS DE IDENTIFICAÇÃO & AC\#01 \\
\hline 002 & B & Depto. - Grupo / Laboratório & $\mathrm{AC} \# 01 / 1$ \\
\hline 003 & $\mathrm{C}$ & Posição no IF/USP & $\mathrm{AC} \# 01 / 2$ \\
\hline 004 & D & Idade & $\mathrm{AC} \# 01 / 3$ \\
\hline 005 & $\mathrm{E}$ & Sexo & $\mathrm{AC} \# 01 / 4$ \\
\hline 006 & $\mathrm{~F}$ & Formação acadêmica- mais alto nível & $\mathrm{AC} \# 01 / 5$ \\
\hline 007 & G & Ano que obteve último título acadêmico & $\mathrm{AC} \# 01 / 6$ \\
\hline 008 & $\mathrm{H}$ & Local que obteve último título acadêmico & $\mathrm{AC} \# 01 / 7$ \\
\hline- & I & Coluna $\mathrm{cm}$ branco & \\
\hline$\cdot$ & J-AR & CONHECIMENTO E USO DA REDE & $\mathrm{AC} \# 02$ \\
\hline 009 & $\mathrm{~J}$ & Experiência com computador & $\mathrm{AC} \# 02 / 1$ \\
\hline - & $\mathrm{K}-\mathrm{M}$ & Experiência com redes cletrônicas & $\mathrm{AC} \# 02 / 2$ \\
\hline 010 & $\mathrm{~K}$ & DECNET & " \\
\hline 011 & $\mathrm{~L}$ & BITNET & $"$ \\
\hline 012 & $\begin{array}{l}\text { M } \\
"\end{array}$ & INTERNET & $"$ \\
\hline- & $\mathrm{N}-\mathrm{AF}$ & Serviços c aplicativos & $\mathrm{AC} \# 02 / 3$ \\
\hline 013 & $\mathrm{~N}$ & Correio eletrônico & $"$ \\
\hline 014 & $\mathrm{O}$ & Transferência de arquivo/FTP & $"$ \\
\hline 015 & $\mathrm{P}$ & Conexăo remota/TELNET & $"$ \\
\hline 016 & $Q$ & Archie & " \\
\hline 017 & $\mathrm{R}$ & Finger & $"$ \\
\hline
\end{tabular}




\begin{tabular}{|c|c|c|c|}
\hline 018 & $S$ & Netfind & $"$ \\
\hline 019 & $\mathrm{~T}$ & VERONICA & $"$ \\
\hline 020 & U & WAIS & $"$ \\
\hline 021 & $\mathrm{~V}$ & BBS & $"$ \\
\hline 022 & W & USENET & $"$ \\
\hline 023 & $\mathrm{X}$ & News do IF & " \\
\hline 024 & Y & CWIS & $"$ \\
\hline 025 & Z & Gopher & $"$ \\
\hline 026 & $\mathrm{AA}$ & Mosaic & $"$ \\
\hline 027 & $\mathrm{AB}$ & WWW & $"$ \\
\hline 028 & $\mathrm{AC}$ & Catálogos de bibliotecas & $"$ \\
\hline 029 & $\mathrm{AD}$ & Base de dados comerciais & $"$ \\
\hline 030 & $\mathrm{AE}$ & Fileserv & $"$ \\
\hline 031 & AF & Outros & $"$ \\
\hline 032 & AG-AI & Propósito de uso das redes & $\mathrm{AC} \# 02 / 4$ \\
\hline 033 & $\mathrm{AJ}$ & Lista de Discussão & $\mathrm{ACH} 02 / 5$ \\
\hline 034 & $\mathrm{AK}-\mathrm{AM}$ & Barreiras no uso das redes & $\mathrm{AC \# 02/6}$ \\
\hline 035 & AN-AP & Barrciras no acesso à informaçāo & $\mathrm{AC} \# 02 / 7$ \\
\hline 036 & $\mathrm{AQ}-\mathrm{AR}$ & Treinamento formal & $\mathrm{AC} \# 02 / 8$ \\
\hline- & AS & Em branco & - \\
\hline- & AT-BF & SITUAÇÃO DE USO RECENTE DAS RE & AC\#03-12 \\
\hline 037 & AT & Contexto de uilização das RE & $\mathrm{AC} \# 03$ \\
\hline 038 & AV & Naturcza da Questāo & $\mathrm{ACH}(1) 4$ \\
\hline 039 & $\mathrm{AW}$ & Foco da Questão & AC\#05 \\
\hline 040 & $\mathrm{AX}$ & Expectativa de uso & AC\#06 \\
\hline 041 & AY & Estratégia empregada & $\mathrm{AC} \# 07$ \\
\hline 042 & $\mathrm{AZ}$ & Resposta recebida & $\mathrm{AC} \# 08 / 1$ \\
\hline 043 & BA & Satisfaçāo percebida & $\mathrm{AC} \# 08 / 2$ \\
\hline 044 & BB & Esforço dispendido & $\mathrm{AC} \# 08 / 3$ \\
\hline 045 & $\mathrm{BC}$ & Critério de completeza & AC\#09 \\
\hline 046 & $\mathrm{BD}$ & Critério de satisfação & $\mathrm{AC} \# 09$ \\
\hline 047 & $\mathrm{BE}$ & Fonte de informaçāo & $\mathrm{AC} \# 10$ \\
\hline 048 & $\mathrm{BF}-\mathrm{BI}$ & Recursos utilizados & $\mathrm{AC} \# 11$ \\
\hline
\end{tabular}




\title{
ESQUEMA PARA ANÁLISE DE CONTEÚDO / AC
}

\author{
PARTE I - Dados de Identificação - AC n ${ }^{\circ} 01 / 1$ a $01 / 7$
}

Questão1.1 - Departamento e Laboratório - AC n ${ }^{0} 01 / 1$

\begin{tabular}{|c|c|}
\hline Código & Categoria \\
\hline $\begin{array}{l}10 \\
11 \\
12 \\
13\end{array}$ & $\begin{array}{l}\text { * DEPTO. FISICA EXPERIMENTAL - FEP } \\
\text { - Grupo de Optica de Cristais Líquidos/GOCL } \\
\text { - Laboratório de Acclerador Linear } \\
\text { - Grupo de Física Nuclear Teórica e Fenomenologia } \\
\text { de Partículas Elementares / FINPE }\end{array}$ \\
\hline $\begin{array}{l}20 \\
21 \\
22 \\
23 \\
24 \\
25 \\
26\end{array}$ & $\begin{array}{l}\text { * DEPTO. FÍSICA GERAL - FGE } \\
\text { - Laboratorio de Instrumentação e Partículas/LIP } \\
\text { - Laboratório de Optica } \\
\text { - Grupo de Física Teórica: Mecanica Estatística c } \\
\text { Fenomenos não Lincares } \\
\text { - Laboratório de Microscopia Eletrônica / LME } \\
\text { - Laboratório de Magncto-Optica / LMO } \\
\text { - Grupo de Biofísica c Física Médica }\end{array}$ \\
\hline $\begin{array}{l}30 \\
31 \\
32 \\
33 \\
34\end{array}$ & $\begin{array}{l}\text { * DEPTO. FÍSICA DOS MATERIAIS E MECANICA - FMT } \\
\text { - Laboratorio de Matcriais Magnéticos } \\
\text { - Laboratório de Novos Materiais Scmicondutores } \\
\text { - Laboratório de Estado Sólido c Baixas Temperaturas } \\
\text { - Grupo de Física Tcorica - Matéria Condensada }\end{array}$ \\
\hline $\begin{array}{l}40 \\
41 \\
42\end{array}$ & $\begin{array}{l}\text { * DEPTO. FÍSICA MATEMÁTICA - FMA } \\
\text { - Grupo Tcoria Quântica de Campos } \\
\text { - Grupo de Particulas Elementares }\end{array}$ \\
\hline $\begin{array}{l}50 \\
51 \\
52 \\
53\end{array}$ & $\begin{array}{l}\text { * DEPTO.FÍSICA NUCLEAR - FNC } \\
\text { - Laboratório do Acelerador Pelletron } \\
\text { - Grupo de Altas Encrgias } \\
\text { - Grupo de Dosimetria }\end{array}$ \\
\hline $\begin{array}{l}60 \\
61 \\
62 \\
63\end{array}$ & $\begin{array}{l}\text { * DEPTO. FíSICA APLICADA - FAP } \\
\text { - Laboratorio de Física de Plasmas - LFP } \\
\text { - Laboratorio de Cristalografia } \\
\text { - Grupo de Estudos de Poluição do Ar (GEPA) }\end{array}$ \\
\hline 70 & * BIBLIOTECA \\
\hline $\begin{array}{l}98 \\
99\end{array}$ & $\begin{array}{l}\text { * OUTROS } \\
* \text { SEM RESPOSTA }\end{array}$ \\
\hline
\end{tabular}

Instruções

1. No caso de algum informante pertencer a mais de um Depto./Laboratório, classifique o que foi indicado primeiro, desconsiderar o ítem OUTROS. 
Questão 1.2 - Posição / Vínculo com o IF - $\mathrm{AC} \mathrm{n}^{\circ} 01 / 2$

\begin{tabular}{ll}
\hline Código & Categoria \\
\hline 10 & CORPO DISCENTE \\
11 & Graduaço (GR) \\
12 & Mestrado (ME) \\
13 & Doutorado (DR) \\
20 & CORPO DOCENTE \\
30 & PESQUISADOR EM PÓS - DOUTORADO \\
40 & TÉCNICO DE APOIO AO ENSINO E PESQUISA-TE
\end{tabular}

Questão 1.3 - Idade - $\mathrm{AC} \mathrm{n}^{\circ} 01 / 3$

\begin{tabular}{ll} 
Código & Catcgoria \\
\hline 00 & $<18$ anos \\
18 & 18 anos \\
19 & 19 anos \\
20 & 20 anos \\
$\ldots 8$ & Outros \\
99 & Sem resposta
\end{tabular}

Instruções :

1. O código deve ser o número exato da idade indicada pelo informante 
Questão 1.4 - Sexo - $\mathrm{AC}^{\circ}{ }^{0} 01 / 4$

\begin{tabular}{|c|c|}
\hline Código & Categoria \\
\hline $\begin{array}{l}0 \\
1 \\
9\end{array}$ & $\begin{array}{l}\text { Masculino } \\
\text { Feminino } \\
\text { Sem resposta }\end{array}$ \\
\hline
\end{tabular}

Questão 1.5A - Formação Acadêmica de mais alto nível (completa) $\mathrm{AC} \mathrm{n}^{\circ} 01 / 5$

\begin{tabular}{ll}
\hline Codigo & Catcgoria \\
\hline 10 & Bacharclado \\
20 & Mestrado \\
30 & Doutorado \\
40 & Pós-Doutorado \\
50 & Livre Docente \\
98 & Outros \\
99 & Sem resposta \\
&
\end{tabular}

Questão 1.5 B - Ano em que obteve o mais alto título acadêmico $\operatorname{AC~}^{0}$ 01/6

Código Catcgoria

$\begin{array}{ll}00 & \text { Em andamento (específico p/alunos de graduação) } \\ 68 & 1968 \\ 69 & 1969 \\ 98 & \text { Outros } \\ 99 & \text { Sem resposta }\end{array}$

\section{Instruções}

1. O código deve corresponder aos dois dígitos finais do ano de formatura. 
Questão 1.5 C - Local / Instituto em que obteve o mais alto título acadêmico $\mathrm{AC} \mathrm{n}^{\circ}$ 01/7

\begin{tabular}{ll}
\hline Código & Categoria \\
\hline $\mathbf{1 0}$ & BRASIL / USP \\
11 & Instituto de Física \\
12 & Outras unidades \\
$\mathbf{2 0}$ & BRASIL / OUTRAS UNIVERSIDADES NÃO USP \\
$\mathbf{3 0}$ & EXTERIOR \\
$\pi 31$ & América do Norte \\
32 & Europa \\
98 & Outros \\
99 & Scm resposta
\end{tabular}


ESQUEMA PARA ANÁLISE DE CONTEÚdO / AC

\section{PARTE II - Conhecimento e Uso dos Recursos da Rede - $A C n^{\circ} 02 / 1$ a $~^{\circ} 02 / 8$}

Questão 2.1 - Experiência com computadores - $\mathbf{A C} \mathbf{n}^{\circ} 02 / 1$

Código

Categoria

$\begin{array}{ll}00 & <6 \text { meses } \\ 01 & 06 \text { a } 12 \text { meses } \\ 02 & 1.1-2.0 \text { anos } \\ 03 & 2.1-3.0 \text { anos } \\ 04 & 3.1-4.0 \text { anos } \\ 05 & 4.1-5.0 \text { anos } \\ 06 & 5.1-6.0 \text { anos } \\ 07 & 6.1-7.0 \text { anos } \\ 08 & 7.1-8.0 \text { anos } \\ 09 & 8.1-9.0 \text { anos } \\ 10 & 9.1-10.0 \text { anos } \\ 11 & 10.1-11.0 \text { anos } \\ 12 & 11.1-12.0 \text { anos } \\ 13 & 12.1-13.0 \text { anos } \\ 14 & 13.1-14.0 \text { anos } \\ 15 & 14.1-15.0 \text { anos } \\ 16 & 15.1-16.0 \text { anos } \\ 17 & 16.1-17.0 \text { anos } \\ 18 & 17.1-18.0 \text { anos } \\ 19 & 18.1-19.0 \text { anos } \\ 20 & >20 \text { anos } \\ 98 & \text { Outros } \\ 99 & \text { Sem resposta }\end{array}$


Questão 2.2 - Conhecimento e Uso dos Recursos das Redes Eletrônicas - AC $n^{\circ} 02 / 2$

Redes DECNet, BITNET e Internet

Código Categoria

\begin{tabular}{|c|c|c|}
\hline 00 & Nunca usou & \\
\hline 01 & $<6$ meses & \\
\hline & & CÓDIGO: \\
\hline 02 & $0.7-1.0$ ano & $1.1=1$ ano $1 \mathrm{mes}$ \\
\hline 03 & $1.1-1.6$ ano & $1.6=1$ ano e 6 meses \\
\hline 04 & $1.7-2.0$ anos & \\
\hline 05 & $2.1-2.6$ anos & \\
\hline 06 & $2.7-3.0$ anos & \\
\hline 07 & $3.1-3.6$ anos & \\
\hline 08 & $3.7-4.0$ anos & \\
\hline 09 & $4.1-4.6$ anos & \\
\hline 10 & $4.7-5.0$ anos & \\
\hline 11 & $5.1-5.6$ anos & \\
\hline 12 & $5.7-6.0$ anos & \\
\hline 13 & $6.1-6.6$ anos & \\
\hline 14 & $6.7-7.0$ anos & \\
\hline 15 & $7.1-7.6$ anos & \\
\hline 16 & $7.7 \cdot 8.0$ anos & \\
\hline 17 & $8.1-8.6$ anos & \\
\hline 18 & $8.7-9.0$ anos & \\
\hline 19 & $9.1-9.6$ anos & \\
\hline 20 & $9.7-10.0$ anos & \\
\hline 21 & $>10$ anos & \\
\hline 96 & Não conheço essa rede & \\
\hline 99 & Sem resposta & \\
\hline
\end{tabular}

\section{Instruções}

1. Cada rede deverá ser classificada individualmente, porém seguindo esse único critério acima. 
Questão 2.3 - Serviços e aplicativos - CA n ${ }^{\circ}$ 02/3

FUNÇÕES BÁSICAS

Questāo $2.3 \mathrm{a}=$ Correio eletrônico

Questão $2.3 \mathrm{~b}=$ Transferência arquivo/FTP

Questão $2.3 \mathrm{c}=$ Conexão remota $/$ Telnet

SERVIÇOS ESPECÍFICOS

Questão 2.3d = Archie

Questão $2.3 \mathrm{e}=$ Finger

Questāo 2.3 $\mathrm{f}=$ Netfind

Questão $2.3 \mathrm{~g}=$ VERONICA

Questão $2.3 \mathrm{~h}=$ WAIS

Questão 2.3 $\mathrm{i}=\mathrm{BBS} /$ Bulletin Board System

Questão $2.3 \mathrm{j}=$ News RDR da USENET

Questão $2.3 k=$ News da Física (VAX)

Questāo 2.31 = CWIS

Questāo $2.3 \mathrm{~m}=$ Gopher

Questāo $2.30=$ WWW /World Wide Web

Questāo 2.3p = Catálogo de biblioteca via rede

Questão $2.3 \mathrm{q}=$ Bases de dados comerciais via rede

Questão 2.3 $\mathrm{r}=$ Fileserv (copia arq. por mail)

OUTROS

Questão 2.3s = Outros. Especifique-os

Código Catcgona

$000 \quad$ Não conheço/Nunca usci

100 Conheço/Nunca Usei

$200 \quad$ Uso de vez em quando

$300 \quad$ Uso várias vezes / mês

400 Uso várias vezes / semana

$500 \quad$ Uso diariamente

600 Relaciona outros serviços utilizados

$900 \quad$ Sem resposta 
Questão 2.4 - Propósito de uso das redes - AC n ${ }^{\circ}$ 02/04

Código Categoria

00

01

02

03

09

10

11

12

20

30

40

50

60

70

80

90

98

99

\section{Utilização das funções básicas da RE}

Correio eletrônico

Transferência de arquivos/programas para computadores de maior porte e vice-versa (FTP)

Compartilhamento de recursos computacionais, conectar-se remotamente (Telnet)

Desenvolvimento de pesquisas. Fins cientificos, profissionais. Trabalho.

\section{PROPÓSITOS ESPECÍFICOS}

Contatar informalmente com pares tanto no país como no cxtcrior

Contatar amigos e colegas

Participar de grupos de discussão

Contatar instituiçōes, laboratórios e agências de fomento

Desenvolver pesquisas $\mathrm{cm}$ colaboração

Efctuar buscas bibliográficas

Obter artigos e pré-prints

Adquirir aplicativos /sof twares de interesse da especialidade

Checar informações sobre as atividades e notícias específicas do IF através do News do VAX

Intercambiar informações gerais, bibliográficas, técnicas c especializadas

Acompanhar o estado-de-arte, atualizar-se

Curiosidade, cultura geral, motivos particulares, lazer, política.

Sem resposta

\section{Instruções}

1. Codificar $\mathrm{cm}$ até 3 categorias. 
Questão 2.5 - Lista de Discussão - AC n 02 / 5

\begin{tabular}{ll} 
Código & Categoria \\
\hline $\mathbf{0 0}$ & Não \\
$\mathbf{1 0}$ & Sim \\
11 & Lista específica na área de física \\
12 & Lista específica na área de informática \\
13 & Listas diversas \\
$\mathbf{9 7}$ & Recusou-se responder \\
98 & Outros \\
99 & Sem resposta
\end{tabular}

\section{Questão 2.6 - Barreiras no Uso das Redes - $A C$ n $^{\circ} 02 / 6$}

Código Catcgoria

$00 \quad$ Não

10 Falta de conhecimentos básicos, pouca familiaridade com os comandos, regras e normas.

20 Desconhecimento dos serviços c recursos disponíveis nas redes

30 Problemas técnicos : lentidão das redes, dificuldade para conexão e transmissão de dados, congestionamento.

40 Falta de treinamento (formal e informal) e de guias e manuais impressos.

50 Instruçōes ("help online") demasiadamente técnicas, acessíveis apenas a especialistas.

98

Outros

$99 \quad$ Sem resposta 
Questões 2.7 - Barreiras no acesso à Informação - AC 02 / 7

\begin{tabular}{|c|c|}
\hline Código & Categona \\
\hline 00 & Não \\
\hline 01 & Nunca utilizou a rede para buscar informaçāo \\
\hline 10 & $\begin{array}{l}\text { Falta de conhecimentos básicos, pouca familiaridade com os } \\
\text { comandos, regras e normas }\end{array}$ \\
\hline 20 & $\begin{array}{l}\text { Desconhecimento dos serviços e recursos, para busca de } \\
\text { informação, disponíveis nas redes }\end{array}$ \\
\hline 30 & $\begin{array}{l}\text { Carência de organização nas redes causando dificuldade na } \\
\text { localização da informação }\end{array}$ \\
\hline 40 & $\begin{array}{l}\text { Problemas com endereçamento exatos: interpretação, identificação } \\
\text { e localização. }\end{array}$ \\
\hline 50 & $\begin{array}{l}\text { Instruçōes ("help online") demasiadamente técnicas, acessíveis } \\
\text { apenas a especialistas. }\end{array}$ \\
\hline 60 & Não confiabilidade nas informações existentes. \\
\hline 98 & Outros \\
\hline 99 & Sem resposta \\
\hline
\end{tabular}

\section{Questões 2.8 - Treinamento Formal - $\mathbf{A C n}^{\circ} 02$ / 8}

Código

Catcgoria

00

01

02

03

04

05

10

98
Não

A prendeu sozinho, tentativas e erros, navegando, praticando Consultando manuais, "helps online", FAQ's

Perguntando a usuarios mais experientes e operadores de sistemas

Trocando informações com amigos e pessoas dirctamente ao lado Buscando auxilio no News da Física e em Listas de Discussão

Sim. (Empresa da família).

Outros 


\title{
ESQUEMA PARA ANÁLISE DE CONTEÚdO / AC \\ PARTE III - Situação recente de uso da rede
}

\author{
Questões 3.1 a $3.12 \cdot \mathrm{AC}^{\circ} 03$ a $\mathrm{AC} \mathrm{n}^{\circ} 12$ \\ - Contexto de utilização das RE - $\mathbf{A C} \mathbf{n}^{0} 03$
}

Código

Categoria

100

110

120

200

210

220

300

310

320

330

\section{Comunicação básica}

- Homem a homem/Pessoal (comunicação interpessoal via cmail e/ou entre grupos de interesse).

- Homem - máquina / Impessoal (Transferência de dados / arquivos, Uso remoto / comunicação online)

Aquisiçāo de conhecimento sobre a RE

- Dados gerais

(conhecimentos básicos sobre a RE, contribuiçōes para desempenho profissional, questionamento sobre medidas de scgurança $\mathrm{c}$ legalidade da informação)

- Serviços da rede (identificando melhor forma de utilizar um serviço especifico para recuperar a informação).

- Busca de soluções para problemas específicos relacionados as atividades profissionais $\mathrm{e} / \mathrm{ou}$ pessoais

- Questões envolvendo procedimentos técnicos (busca de normas e instruções para instalação, uso, características técnicas de softwares)

- Questões administrativas e pessoais (importação de materiais, conta $\mathrm{cm}$ redes externas, problemas de documentação pessoal)

- Questões envolvendo intercambio / prestação de serviços (envio de artigos para revisão, acordos internacionais, gráficos para publicação entre outros) 
400

- Busca de informações / dados técnicos e científicos para desenvolvimento de atividades profissionais

410

- Informaçāo bibliográfica (engloba levantamentos bibliográficos, procura de referências completas de documentos, bibliografia)

420

- Informação não-bibliográfica (levantamento de softwares em geral, busca de tabelas, dados estatísticos)

430

- Informação rápida e momentânea (localização de sof tware específico e endereço de máquinas, de pessoas e de repositórios publicos)

440

- Informação para atualização

(estado da arte, reciclagem, "update", acompanhamento da litcratura especializada na área)

\section{Instruções}

1. Está sendo categorizado o contexto global da situação que levou os informantes a usar a rede cletrônica. 
- 5 W's - Natureza da Questão do Usuário - $A C n^{\circ} 04$

Código Categoria

Descriçāo

$\begin{array}{lll}40 & \begin{array}{l}\text { Oque } \\ \text { (What) }\end{array} & \begin{array}{l}\text { - identificar algo que não é precisamente uma } \\ \text { pessoa, é um objeto ou condição situacional }\end{array} \\ 50 & \begin{array}{l}\text { Quem } \\ \text { (Who) }\end{array} & \begin{array}{l}\text { - identificar uma ou mais pessoas, o que fazem, } \\ \text { o que querem }\end{array} \\ 10 & \begin{array}{l}\text { Onde } \\ \text { (Where) }\end{array} & \text { - aqui se busca localizar alguma coisa no espaço } \\ 60 & \begin{array}{l}\text { Quando } \\ \text { (When) }\end{array} & \begin{array}{l}\text { - questōes buscando localizar alguma coisa no } \\ \text { tempo }\end{array} \\ 30 & \begin{array}{l}\text { Como } \\ \text { (How) }\end{array} & \begin{array}{l}\text { - determinar os procedimentos ou habilidades ne- } \\ \text { cessárias para se mover de um local a outro. }\end{array} \\ 98 & \begin{array}{l}\text { Porque } \\ \text { (Why) }\end{array} & \text { - identificar razões, causas c explicações das coisas. } \\ 99 & \text { Outros } & \end{array}$

\section{Instruções}

1. Codificar o significado da questão do informante c näo somente trabalhar com palav ras contextuais

2. A categoria "Como" reflete etapas do processo, envolvendo tempo, espaco e movimento.

3. A categoria "Quem" inclui a identificação de si próprio ou algo sobre alguém.

4. A categoria "O que" não deve expressar nenhum tipo de movimento. 
Código Categoria

Descriçāo

10

20

30

40

50

60

98

99
A própria pessoa

- o foco pode recair em alguma habilidade essencial ao informante, ou uma necessidade de informação para decisões interiores

Explo. "Posso me recadastrar estando afastado?"

Outras pessoas

Situaçāol

Situação2

Situação3

Objeto ou coisa

- há expectativa de solução de parte de outra pessoa e/ou profissional.

Explo. "Ele está entendendo o meu problema?"

- solução adequada a determinada situação, que envolve trabalho especializado.

Explo.: "O que de fato está ocorrendo no micro?"

- situação envolvendo um recurso ou serviço específico da rede.

Explo: "Como funciona o Archic mesmo?"

- situação envolvendo a própria rede de mancira global - confiabilidade no sistema.

Explo: "Como pode ser útil ao meu trabalho o uso global da rede?"

- quando envolve algo concreto, tangível ou que sirva como documento.

Explo: "Onde estará esse software?"

\section{Outros}

Sem resposta

\section{Instruções}

1. A codificação refere-se ao foco da questão do informante, isto é, a variável "LACUNA".

2. Em caso de dúvida quanto as categorias 03,04 e 05 - pertinentes a SITUAÇÃO - utilizar o código 30 que é o mais genérico.

3. A categoria "Objeto" não deve mostrar nenhum movimento temporal e/ou espacial, em caso de dúvida categorizar como 30.

4. A categoria "Própria pessoa" deve expressar muito claramente uma "lacuna" pessoal, ou algo interior do informante. Em caso de dúvida, utilizar a categoria 30. 


\section{- Expectativa de Uso da Informação Necessária - $\mathrm{AC}$ n $^{\circ} 06$}

\section{Código Categoria}

- Continuidade crescente no desempenho

(o informante espera que a resposta 'a sua questão lhe possibilite contínuc caminhada, transpor a lacuna e empreender o próximo passo).

20 - Contato com outras pessoas

(envolve estar acompanhado, comunicar-se, conectar-se com outros).

- Desenvolvimento de habilidades e/ou aquisição de conhecimentos (aprender algo, adquirir habilidade tanto motora como cognitiva).

40

- Compreensão da situação

(visualizar melhor o contexto, inclui também obter controle da situação)

Alcance de objetivos e metas

(solucionar o problema, finalizar o movimento ou o processo)

60

Plancjamento de "o que, quando c como" fazer algo (planejar, decidir, escolher entre dois caminhos).

Sem resposta

\section{Instruções}

1. O que está em pauta é o benefício que o informante esperar obter com a resposta `a suz questão. Corresponde especificamente ao ítem 3.4 do questionário. 
- Estratégia empreendida pelo usuário - $\mathrm{AC}^{0} 07$

Código Categoria

10

Consultar a si mesmo, utilizar próprios conhecimentos, raciocinar.

20

Consultar pessoas ao lado, colegas e amigos

21

- por correio eletrônico

- facc-a-face

30

Consultar pares, profissionais, pessoas com perfil condizente

31

- por correio eletrônico

- face-a-face

- via grupo de discussão, USENET, BBS

40

Consultar outros recursos

41

- recursos e serviços via rede (inclue Help)

42

- recursos e serviços fora da rede

50 Desenvolver procedimentos por si próprio, testar, comparar

60 Esperar, aguardar resultado final

70 Desistir

80 Optar por solução alternativa, resolver a situação mas não a questão.

90

Nenhuma estratégia

98

Outras

99

Sem resposta

Instruções

1. A tabela apresenta uma categorizaçāo das "estratégias desenvolvidas pelo informante para solucionar a questão em pauta, não a situação.

2. Utilizar até 2 códigos para definir melhor a estratégia empregada. 
- Completeza da Resposta Obtida - AC n ${ }^{\circ}$ 08/1

\begin{tabular}{ll}
\hline Código & Categoria \\
\hline 0 & Não \\
1 & Parcial \\
2 & Completa \\
3 & Excessiva \\
9 & Sem resposta
\end{tabular}

- Satisfação com a Resposta Obtida - AC n ${ }^{\circ} 08 / 2$

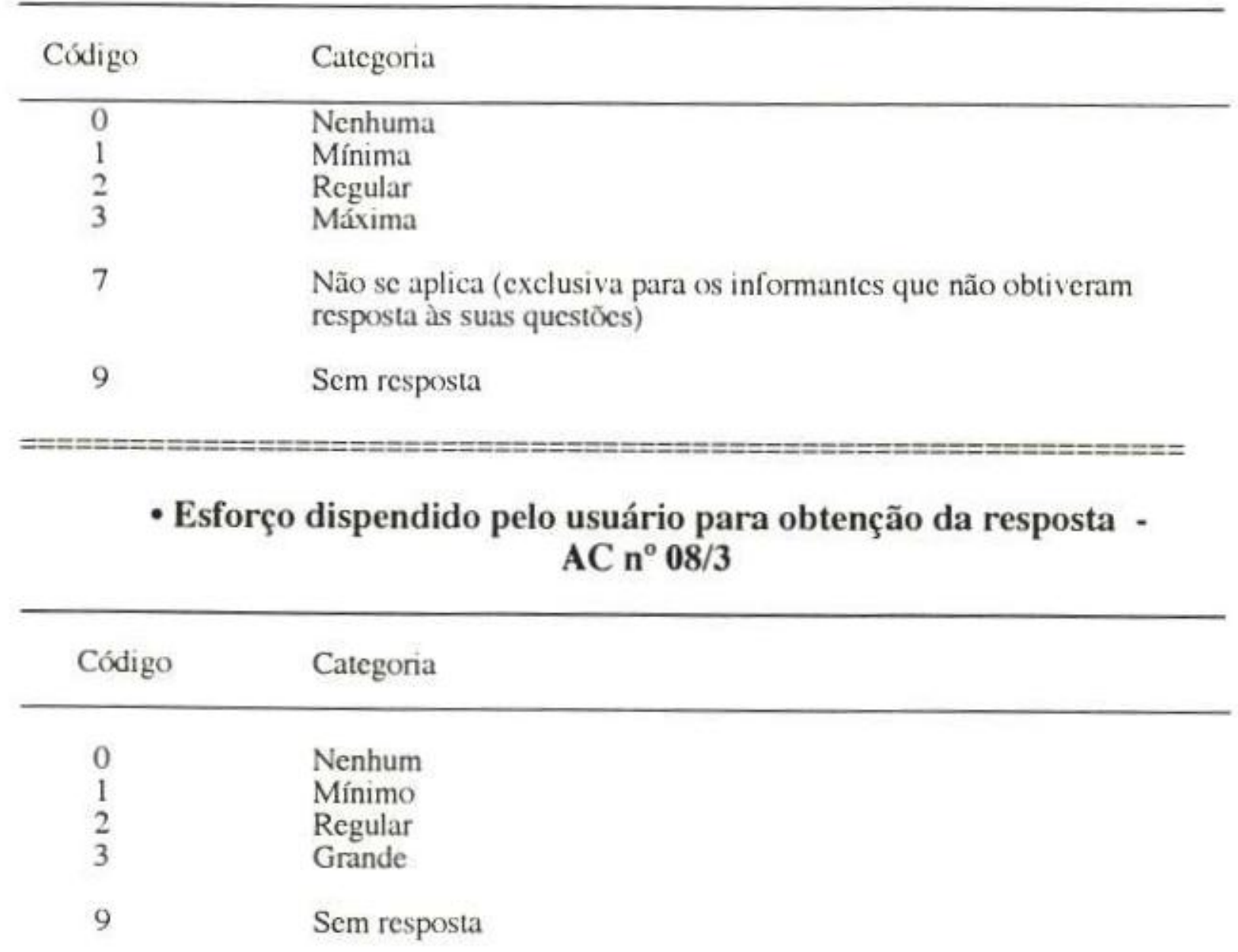


- Critérios para avaliação da completeza da resposta e satisfação pessoal $\mathrm{AC} \mathrm{n}^{\circ} 09$

Código Categoria

00

10

11 problema.

12

13

solução.

14

20

21

22

30

31

32

33

40

41

43

99
Específico para informantes que não obtiveram respostas as suas questōes.

\section{QUANTO A INFORMAÇÃO PROPRIAMENTE DITA}

Atingir o objetivo. Conseguir exatamente o que se quer. Solucionar o

Solucionar parte do problema.

Não atender exatamente a expectativa, mas fornecer a direçāo para a

Informação pré-definida. A resposta só poderia ser sim ou nāo.

\section{QUANTO AS HABILIDADES PESSOAIS}

Desconhecer outra maneira de contornar o problema.

Compreender melhor o problema, a situação.

\section{QUANTO A FONTE DE INFORMAÇÃO}

Eficiência dos serviços da rede

Dificuldades no uso da rede

Confiabilidade.

\section{QUANTO A FORMA DE SOLUCIONAR O PROBLEMA}

Solucionar o problema de forma mais simples e rápida.

Economia (dinheiro, tempo)

Sem resposta.

Instruçōes:

1. Esses critérios podem ser considerados positivamente ou nāo. Exemplo: O informante se mostra satisfeito porque conseguiu resolver o problema de maneira fácil e simples - ou - O informante não se mostra satisfeito com a resposta porque não resolveu o problema de forma simples e fácil. 
- Fontes de Informação - $A C n^{\circ} 10$

Código Categoria

10

Própria pessoa

(experiência pessoal, próprios conhecimentos)

20

Pessoas em geral

(amigos, colegas, pessoas ao lado)

30

Autoridade na área $\mathrm{em}$ foco

(profissionais, especialistas, orientador)

40

Recursos e serviços disponíveis via rede

(archie, mosaic, help onlinc, gopher)

50

Nenhuma fonte

98

Outras

99

Sem resposta

\section{Instruções}

1. Está sendo codificada, EXCLUSIVAMENTE, a fonte que forneceu alguma tipo de auxilio ao informante quanto a solução de sua questão.

2. As demais fontes utilizadas pelo informante devem ser inseridas na tabela "Recursos de Informação Utilizados" - $\mathrm{AC} \mathrm{n}^{\circ} 11$. 
- Recursos Informacionais Utilizados - $\mathbf{A C ~} \mathbf{n}^{\circ} 11$

Código Categoria

10

11

12

13

14

15

20

21

22

23

24

25

26

27

28

35

36

37

38

40

41

42

43

\section{PESSOAIS / CONTATOS INFORMAIS}

Própria pessoa, próprios conhecimentos

Colegas

Aluno de pós-graduaçāo

Profissionais diversos / Professor

Postmaster / Gerente do Sistema / Assistência Técnica

RECURSOS DA REDE

Help online, FAQ

Email

FTP

Talk

Archic

Finger

Netfind

WAIS

\section{SERVIÇOS DA REDE OU VIA REDE}

Repositórios de Domínio Público

Banco de Dados/ catálogos de bibliotecas (inclue DEDALUS).

Livrarias, cditores

WWW

Gopher

Listas de discussão

Pre-prints / BBS

News do Vax / USENET

SERVIÇ OS E RECURSOS FORA DA REDE

Livrarias

Revistas de informática

Telefone. 


\section{Apêndice C}

TABELA

Uso dos recursos e serviços disponíveis nas

redes eletrônicas 


\section{APÊNDICE C}

Apresentação dos dados coletados quanto a frequência de uso de cada um dos vários recursos e serviços disponíveis nas redes eletrônicas.

USO DOS RECURSOS E SERVIÇOS DISPONIVEIS NAS RE $X$ CLASSES DE USUÁRIOS DA REDE IFUSP

\begin{tabular}{|c|c|c|c|c|c|c|c|c|c|c|c|}
\hline \multirow{2}{*}{ CATEGORIAS USUÁRIOS } & \multicolumn{4}{|c|}{ ALUNO } & \multicolumn{4}{|c|}{ DOCENTE } & \multirow{2}{*}{$\frac{\text { PESQ }}{\mathrm{DR}}$} & \multirow{2}{*}{\begin{tabular}{|c|} 
FUNC \\
GR \\
\end{tabular}} & \multirow[t]{2}{*}{ TOTAL } \\
\hline & GR & ME & DR & ST & DR & $\mathrm{PD}$ & LD & ST & & & \\
\hline \multicolumn{12}{|l|}{ CORREIO ELETRÔNICO } \\
\hline Năo Conheço/Nunca usei & - & - & - & - & - & - & - & - & - & - & - \\
\hline Conheço/Nunca usei & - & - & - & - & - & - & - & - & - & 2 & 2 \\
\hline Uso de vez em quando & 1 & 3 & 2 & 6 & - & - & - & - & - & 1 & 7 \\
\hline Uso várias vezes/mês & 2 & 1 & 2 & 5 & 2 & - & - & 2 & 1 & 1 & 9 \\
\hline Uso várias vezes/semana & 1 & 3 & 7 & 11 & 2 & - & 1 & 3 & - & 1 & 15 \\
\hline Uso diariamente & 1 & 6 & 14 & 21 & 18 & 2 & 2 & 22 & 8 & 3 & 54 \\
\hline TOTAL & 5 & 13 & 25 & 43 & 22 & 2 & 3 & 27 & 9 & 8 & 87 \\
\hline \multicolumn{12}{|l|}{ FTP } \\
\hline Não Conheço/Nunca usei & - & - & 1 & 1 & 2 & - & - & 2 & 1 & 2 & 6 \\
\hline Conheço/Nunca usei & - & 1 & 1 & 2 & 2 & - & - & 2 & - & 2 & 6 \\
\hline Uso de vez em quando & - & 2 & 5 & 7 & 5 & 1 & 1 & 7 & 2 & - & 16 \\
\hline Uso várias vezes/mès & 3 & 2 & 8 & 13 & 4 & - & - & 4 & 2 & 1 & 20 \\
\hline Uso várias vezes/semana & 2 & 6 & 7 & 15 & 5 & 1 & 1 & 7 & 2 & 1 & 25 \\
\hline Uso diariamente & - & 2 & 3 & 5 & 4 & - & 1 & 5 & 2 & 2 & 14 \\
\hline TOTAL & 5 & 13 & 25 & 43 & 22 & 2 & 3 & 27 & 9 & 8 & 87 \\
\hline \multicolumn{12}{|l|}{ TELNET } \\
\hline Não Conheço/Nunca usei & - & - & 1 & 1 & 2 & - & - & 2 & 1 & 2 & 6 \\
\hline Conheço/Nunca usei & - & 1 & 2 & 3 & - & - & 1 & 1 & - & 1 & 5 \\
\hline Uso de vez em quando & - & 3 & 5 & 8 & 9 & 1 & - & 10 & 1 & 1 & 20 \\
\hline Uso várias vezes/mès & 4 & 3 & 3 & 10 & 3 & - & - & 3 & 3 & 2 & 18 \\
\hline Uso várias vezes/semana & - & 3 & 4 & 7 & 4 & - & - & 4 & 2 & 2 & 15 \\
\hline Uso diariamente & 1 & 3 & 10 & 14 & 4 & 1 & 2 & 7 & 2 & - & 23 \\
\hline TOTAL & 5 & 13 & 25 & 43 & 22 & 2 & 3 & 27 & 9 & 8 & 87 \\
\hline
\end{tabular}


USO DOS RECURSOS E SERVIÇOS DISPONIVEIS NAS RE'

$X$ CLASSES DE USUÁRIOS DA REDE IFUSP (continuação)

\begin{tabular}{|c|c|c|c|c|c|c|c|c|c|c|c|}
\hline \multirow{2}{*}{ CATEGORIAS USUÁRIOS } & \multicolumn{4}{|c|}{ ALUNO } & \multicolumn{4}{|c|}{ DOCENTE } & \multirow{2}{*}{\begin{tabular}{c|} 
PESQ \\
$D R$ \\
\end{tabular}} & \multirow{2}{*}{\begin{tabular}{|c|} 
FUNC \\
GR \\
\end{tabular}} & \multirow[t]{2}{*}{ TOTAL } \\
\hline & GR & $\mathrm{ME}$ & DR & ST & $\mathrm{DR}$ & PD & LD & ST & & & \\
\hline \multicolumn{12}{|l|}{ ARCHIE } \\
\hline Năo Conheço/Nunca usei & 1 & 10 & 15 & 26 & 16 & 1 & 2 & 19 & 7 & 3 & 55 \\
\hline Conheço/Nunca usei & 2 & 1 & 5 & 8 & 3 & - & 1 & 4 & 2 & 1 & 15 \\
\hline Uso de vez em quando & 1 & 1 & 3 & 5 & 3 & - & - & 3 & - & 4 & 12 \\
\hline Uso várias vezes/mês & - & 1 & 1 & 2 & $\cdot$ & 1 & - & 1 & - & - & 3 \\
\hline Uso várias vezes/semana & 1 & - & 1 & 2 & - & - & - & - & - & - & 2 \\
\hline Uso diariamente & - & - & - & - & - & - & - & - & - & - & - \\
\hline TOTAL & 5 & 13 & 25 & 43 & 22 & 2 & 3 & 27 & 9 & 8 & 87 \\
\hline
\end{tabular}

FINGER

\begin{tabular}{l|ccc|c|ccc|c|c|c|c} 
Não Conheço/Nunca usei & - & 1 & 4 & 5 & 7 & - & 1 & 8 & 2 & 2 & 17 \\
Conheço/Nunca usei & - & 1 & 3 & 4 & 4 & - & 1 & 5 & 1 & 1 & 11 \\
Uso de vez em quando & 1 & 4 & 10 & 15 & 5 & 2 & 1 & 8 & 3 & 3 & 29 \\
Uso várias vezes/més & 1 & 3 & 2 & 6 & 2 & - & - & 2 & 2 & - & 10 \\
Uso várias vezes/semana & 3 & 4 & 3 & 10 & 2 & - & - & 2 & - & 2 & 14 \\
Uso diariamente & - & - & 3 & 3 & 2 & - & - & 2 & 1 & - & 6 \\
\hline \hline TOTAL & 5 & 13 & 25 & 43 & 22 & 2 & 3 & 27 & 9 & 8 & 87 \\
\hline \hline
\end{tabular}

NETFIND

\begin{tabular}{l|ccc|c|ccc|c|c|c|c} 
Não Conheço/Nunca usei & 3 & 5 & 16 & 24 & 16 & 1 & 1 & 18 & 5 & 2 & 49 \\
Conheço/Nunca usei & - & 3 & 3 & 6 & 2 & - & 1 & 3 & 2 & 3 & 14 \\
Uso de vez em quando & - & 4 & 4 & 8 & 3 & 1 & 1 & 5 & 1 & 3 & 17 \\
Uso várias vezes/mès & 2 & 1 & 2 & 5 & 1 & - & - & 1 & - & - & 6 \\
Uso várias vezes/semana & - & - & - & - & - & - & - & - & 1 & - & 1 \\
Uso diariamente & - & - & - & - & - & - & - & - & - & - & - \\
\hline \hline TOTAL & 5 & 13 & 25 & 43 & 22 & 2 & 3 & 27 & 9 & 8 & 87 \\
\hline \hline
\end{tabular}


USO DOS RECURSOS E SERVIÇOS DISPONIVEIS NAS RE

$X$ CLASSES DE USUÁRIOS DA REDE IFUSP (continuação)

\begin{tabular}{|c|c|c|c|c|c|c|c|c|c|c|c|}
\hline \multirow{2}{*}{ CATEGORIAS USUÁRIOS } & \multicolumn{4}{|c|}{ ALUNO } & \multicolumn{4}{|c|}{ DOCENTE } & \multirow{2}{*}{\begin{tabular}{c|} 
PESQ \\
$D R$ \\
\end{tabular}} & \multirow{2}{*}{ FUNC } & \multirow[t]{2}{*}{ TOTAL } \\
\hline & GR & ME & DR & ST & DR & PD & LD & ST & & & \\
\hline \multicolumn{12}{|l|}{ VERONICA } \\
\hline Não Conheço/Nunca usei & 4 & 11 & 21 & 36 & 20 & 2 & 3 & 25 & 6 & 6 & 73 \\
\hline Conheço/Nunca usei & 1 & - & 2 & 3 & 1 & - & - & 1 & 3 & 1 & 8 \\
\hline Uso de vez em quando & - & 2 & 1 & 3 & - & - & - & - & - & 1 & 4 \\
\hline Uso várias vezes/mes & - & - & 1 & 1 & 1 & - & - & 1 & - & - & 2 \\
\hline Uso várias vezes/semana & - & - & - & - & - & - & - & - & - & - & - \\
\hline Uso diariamente & $\therefore$ & - & - & - & - & - & - & - & - & - & - \\
\hline TOTAL & 5 & 13 & 25 & 43 & 22 & 2 & 3 & 27 & 9 & 8 & 87 \\
\hline
\end{tabular}

WAIS

\begin{tabular}{l|ccc|c|ccc|c|c|c|c} 
Não Conheço/Nunca usei & 1 & 5 & 20 & 26 & 5 & - & 2 & 7 & 4 & 3 & 40 \\
Conheço/Nunca usei & 2 & 6 & 4 & 12 & 9 & 2 & - & 11 & 3 & 4 & 30 \\
Uso de vez em quando & 2 & 2 & - & 4 & 5 & - & 1 & 6 & 1 & - & 11 \\
Uso várias vezes/mès & - & - & 1 & 1 & - & - & - & - & - & - & 1 \\
Uso várias vezes/semana & - & - & - & - & 2 & - & - & 2 & - & 1 & 3 \\
Uso diariamente & - & - & - & - & 1 & - & - & 1 & 1 & - & 2 \\
\hline \hline TOTAL & 5 & 13 & 25 & 43 & 22 & 2 & 3 & 27 & 9 & 8 & 87 \\
\hline \hline
\end{tabular}

BBS

\begin{tabular}{l|ccc|cccc|c|c|c|c} 
Nåo Conheço/Nunca usei & 2 & 6 & 9 & 17 & 15 & - & 2 & 17 & 3 & 3 & 40 \\
Conheço/Nunca usei & - & 1 & 8 & 9 & 4 & - & 1 & 5 & 4 & 2 & 20 \\
Uso de vez em quando & 1 & 3 & 4 & 8 & 3 & 1 & - & 4 & 2 & 2 & 16 \\
Uso várias vezes/mès & 1 & - & 1 & 2 & - & - & - & - & - & - & 2 \\
Uso várias vezes/semana & - & 3 & 3 & 6 & - & - & - & - & - & 1 & 7 \\
Uso diariamente & 1 & - & - & 1 & - & 1 & - & 1 & - & - & 2 \\
\hline \hline TOTAL & 5 & 13 & 25 & 43 & 22 & 2 & 3 & 27 & 9 & 8 & 87 \\
\hline \hline
\end{tabular}


USO DOS RECURSOS E SERVIÇOS DISPONIVEIS NAS RE

$X$ CLASSES DE USUÁRIOS DA REDE IFUSP (continuaçăo)

\begin{tabular}{|c|c|c|c|c|c|c|c|c|c|c|c|}
\hline \multirow{2}{*}{ CATEGORIAS USUÁRIOS } & \multicolumn{4}{|c|}{ ALUNO } & \multicolumn{4}{|c|}{ DOCENTE } & \multirow{2}{*}{$\frac{\text { PESQ }}{\text { DR }}$} & \multirow{2}{*}{\begin{tabular}{|c|} 
FUNC \\
GR \\
\end{tabular}} & \multirow[t]{2}{*}{ TOTAL } \\
\hline & GR & ME & $\mathrm{DR}$ & ST & DR & $\mathrm{PD}$ & LD & ST & & & \\
\hline \multicolumn{12}{|l|}{ USENET } \\
\hline Não Conheço/Nunca usei & - & - & - & - & 3 & - & - & 3 & - & 1 & 4 \\
\hline Conheço/Nunca usei & 1 & - & 2 & 3 & 3 & - & - & 3 & - & 1 & 7 \\
\hline Uso de vez em quando & 1 & 3 & 4 & 8 & 6 & 1 & 3 & 10 & 2 & 1 & 21 \\
\hline Uso várias vezes/mès & 1 & 1 & 7 & 9 & 4 & - & - & 4 & 1 & - & 14 \\
\hline Uso várias vezes/semana & 1 & 4 & 5 & 10 & 5 & 1 & - & 6 & 3 & 4 & 23 \\
\hline Uso diariamente & 1 & 5 & 7 & 13 & 1 & - & - & 1 & 3 & 1 & 18 \\
\hline TOTAL & 5 & 13 & 25 & 43 & 22 & 2 & 3 & 27 & 9 & 8 & 87 \\
\hline \multicolumn{12}{|l|}{ NEWS DO IFUSP } \\
\hline Não Conheço/Nunca usei & 4 & 10 & 21 & 35 & 18 & 1 & 3 & 22 & 8 & 4 & 69 \\
\hline Conheço/Nunca usei & 1 & 2 & 2 & 5 & 3 & 1 & - & 4 & 1 & 2 & 12 \\
\hline Uso de vez em quando & - & 1 & 2 & 3 & - & - & - & - & - & 2 & 5 \\
\hline Uso várias vezes/mês & - & - & - & - & 1 & - & - & 1 & - & - & 1 \\
\hline Uso várias vezes/semana & - & - & - & - & - & - & - & - & - & - & - \\
\hline Uso diariamente & - & - & - & - & - & - & - & - & - & - & - \\
\hline TOTAL & 5 & 13 & 25 & 43 & 22 & 2 & 3 & 27 & 9 & 8 & 87 \\
\hline \multicolumn{12}{|l|}{ CWIS } \\
\hline Nāo Conheço/Nunca usei & 4 & 11 & 22 & 37 & 20 & 2 & 3 & 25 & 8 & 7 & 77 \\
\hline Conheço/Nunca usei & 1 & 2 & 3 & 6 & 2 & - & - & 2 & 1 & 1 & 10 \\
\hline Uso de vez em quando & - & - & - & - & - & - & - & - & - & - & - \\
\hline Uso várias vezes/mês & - & - & - & - & - & - & - & - & - & - & - \\
\hline Uso várias vezes/semana & - & - & - & - & - & - & - & - & - & - & - \\
\hline Uso diariamente & - & - & - & - & - & - & - & - & - & - & - \\
\hline TOTAL & 5 & 13 & 25 & 43 & 22 & 2 & 3 & 27 & 9 & 8 & 87 \\
\hline
\end{tabular}


USO DOS RECURSOS E SERVIC̨OS DISPONIVEIS NAS RE

X CLASSES DE USUÁRIOS DA REDE IFUSP (continuaçāo)

\begin{tabular}{|c|c|c|c|c|c|c|c|c|c|c|c|}
\hline \multirow[b]{2}{*}{ CATEGORIAS } & \multicolumn{4}{|c|}{ ALUNO } & \multicolumn{4}{|c|}{ DOCENTE } & \multirow{2}{*}{\begin{tabular}{|c|} 
PESQ \\
DR \\
\end{tabular}} & \multirow{2}{*}{$\begin{array}{c}\text { FUNC } \\
\text { GR } \\
\end{array}$} & \multirow[t]{2}{*}{ TOTAL } \\
\hline & GR & ME & $\mathrm{DR}$ & ST & DR & PD & LD & ST & & & \\
\hline \multicolumn{12}{|l|}{ GOPHER } \\
\hline Não Conheço/Nunca usei & 2 & 7 & 11 & 20 & 10 & - & 2 & 12 & 2 & 2 & 36 \\
\hline Conheço/Nunca usei & 2 & 1 & 8 & 11 & 6 & 2 & - & 8 & 2 & - & 21 \\
\hline Uso de vez em quando & 1 & 4 & 4 & 9 & 5 & - & 1 & 6 & 5 & 4 & 24 \\
\hline Uso várias vezes/mès & - & 1 & 1 & 2 & 1 & $\cdot$ & $\cdot$ & 1 & - & $\cdot$ & 3 \\
\hline Uso várias vezes/semana & - & - & 1 & 1 & - & - & - & - & - & 1 & 2 \\
\hline Uso diariamente & - & - & - & - & $=$ & - & - & - & - & 1 & 1 \\
\hline TOTAL & 5 & 13 & 25 & 43 & 22 & 2 & 3 & 27 & 9 & 8 & 87 \\
\hline \multicolumn{12}{|l|}{ WWW } \\
\hline Não Conheço/Nunca usei & 3 & 7 & 12 & 22 & 12 & - & 2 & 14 & 1 & 3 & 40 \\
\hline Conheço/Nunca usei & 1 & 3 & 5 & 9 & 5 & - & 1 & 6 & 2 & - & 17 \\
\hline Uso de vez em quando & $\cdot$ & 3 & 5 & 8 & 1 & 1 & - & 2 & 5 & 3 & 18 \\
\hline Uso várias vezes/mês & - & $\cdot$ & - & $\cdot$ & 1 & 1 & - & 2 & 1 & - & 3 \\
\hline Uso várias vezes/semana & - & - & 3 & 3 & 2 & - & $\cdot$ & 2 & - & 2 & 7 \\
\hline Uso diariamente & 1 & - & - & 1 & 1 & - & - & 1 & - & - & 2 \\
\hline TOTAL & 5 & 13 & 25 & 43 & 22 & 2 & 3 & 27 & 9 & 8 & 87 \\
\hline
\end{tabular}




\section{Apêndice D}

\section{MATRIZ}

Variáveis dos estudos

$x$

Itens do instrumento de pesquisa

SÍNTESE DO PLANEJAMENTO DO INSTRUMENTO DE PESQUISA 


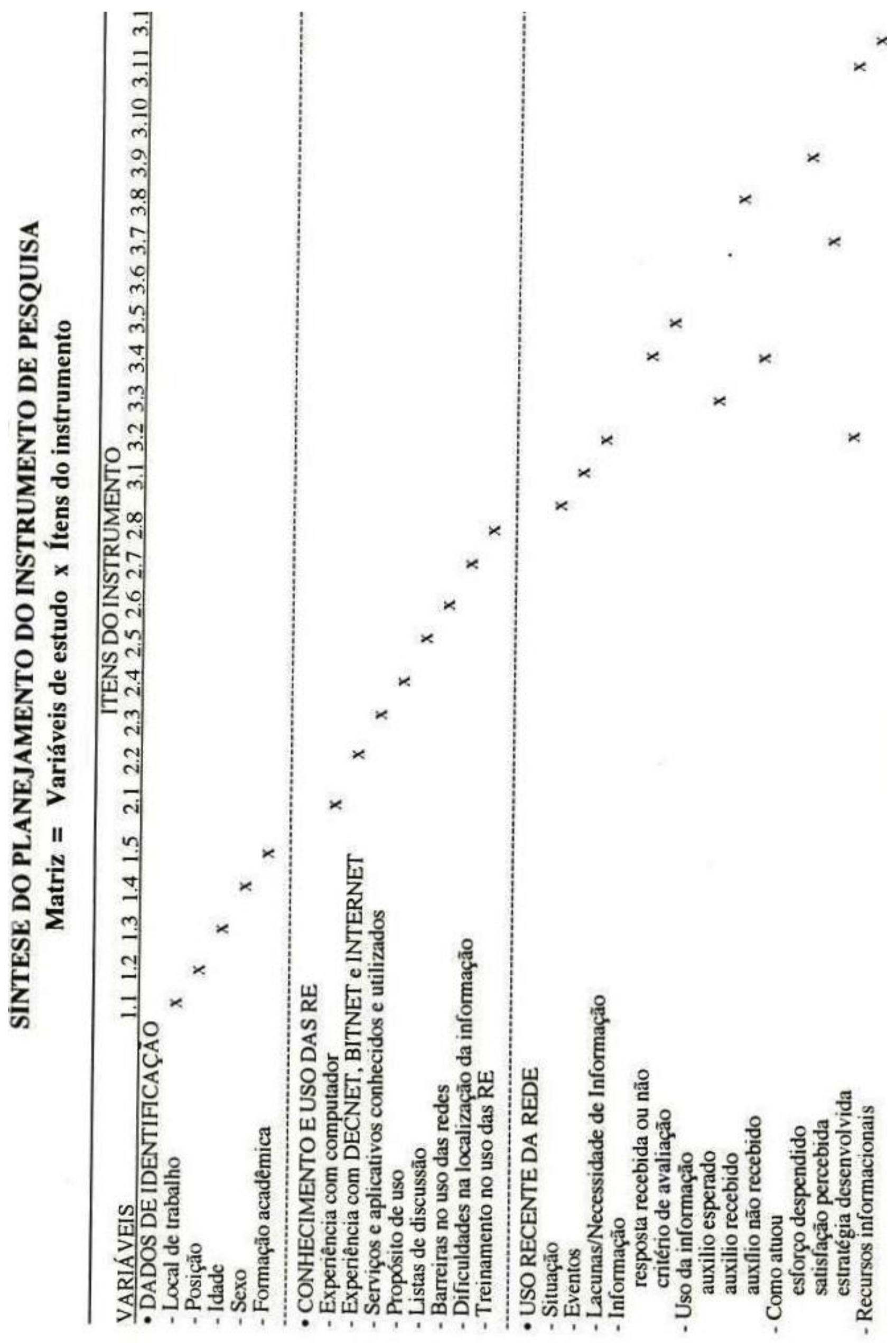

